Studies on Islamic Cultural and Intellectual History

\title{
Indonesian and German views on the Islamic legal discourse on gender and civil rights
}

\author{
Edited by \\ Noorhaidi Hasan and Fritz Schulze
}

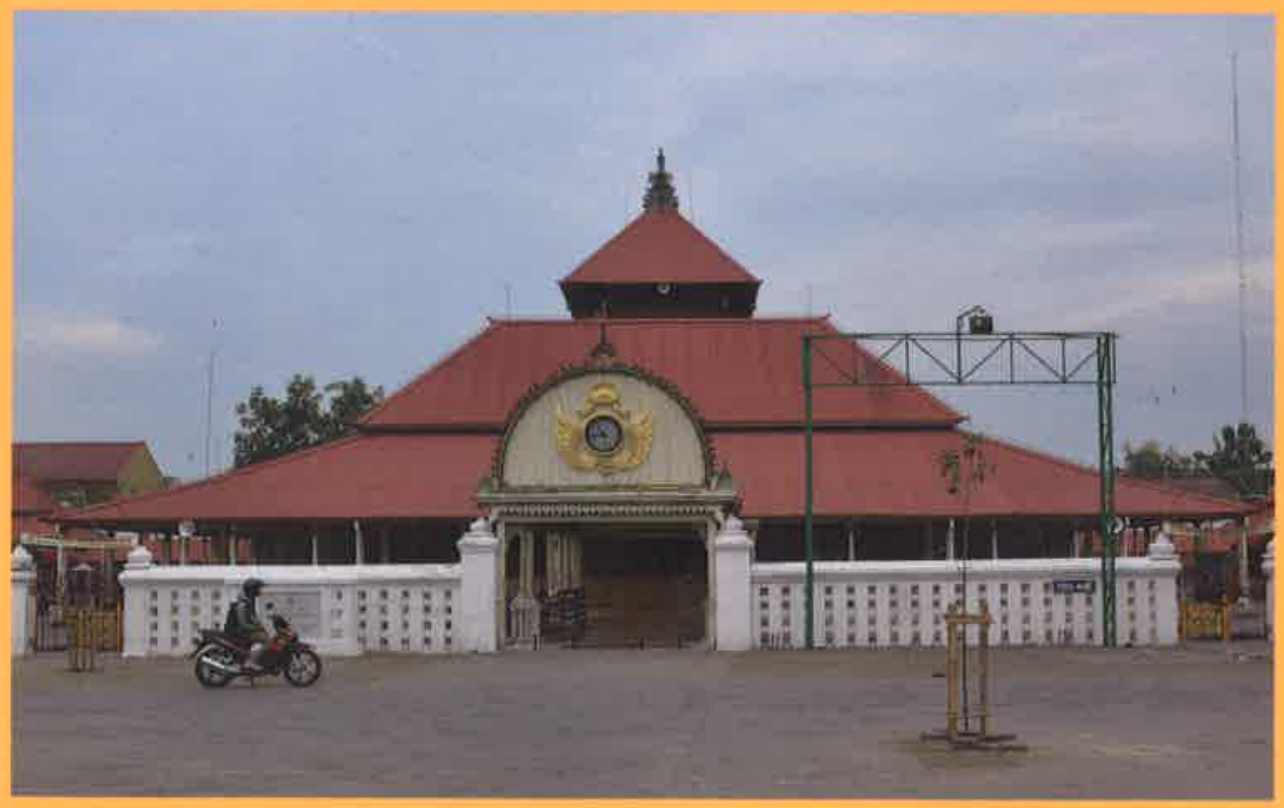

Harrassowitz Verlag 


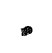




\title{
Studies on Islamic Cultural and Intellectual History
}

\author{
Edited by \\ Noorhaidi Hasan, Irene Schneider \\ and Fritz Schulze
}

Volume 1

2015

Harrassowitz Verlag · Wiesbaden 


\title{
Indonesian and German views on the Islamic legal discourse on gender and civil rights
}

\author{
Edited by \\ Noorhaidi Hasan and Fritz Schulze
}

2015

Harrassowitz Verlag · Wiesbaden 
Cover illustration: Mesjid Gedhe Kauman, the royal mosque of Yogyakarta (Photo: Fritz Schulze).

Bibliografische Information der Deutschen Nationalbibliothek

Die Deutsche Nationalbibliothek verzeichnet diese Publikation in der Deutschen Nationalbibliografie; detaillierte bibliografische Daten sind im Internet über http://dnb.dnb.de abrufbar.

Bibliographic information published by the Deutsche Nationalbibliothek The Deutsche Nationalbibliothek lists this publication in the Deutsche Nationalbibliografie; detailed bibliographic data are available on the internet at http://dnb.dnb.de.

For further information about our publishing program have a look at our website http://www.harrassowitz-verlag.de

(C) Otto Harrassowitz GmbH \& Co. KG, Wiesbaden 2015

This work, including all of its parts, is protected by copyright. Any use beyond the limits of copyright law without the permission of the publisher is forbidden and subject to penalty. This applies particularly to reproductions, translations, microfilms and storage and processing in electronic systems.

Printed on permanent/durable paper.

Printing and binding: Hubert \& Co., Göttingen

Printed in Germany

ISSN 2364-7884

ISBN 978-3-447-10512-5 


\section{Table of content}

Introduction

Hamim Ilyas

The concept of sharia in the Qur'an and its relevance

with gender discourse

Syafiq Hasyim

Gender, the problem of patriarchy and maslaha in Indonesian Islam:

from fiqh al-'abawī to fiqh al-nis $\bar{a}$ '....

Siti Ruhaini Dzuhayatin

Gender as a social regime in the Islamic context -

a case study of the Muhammadiyah.

Fritz Schulze

Indonesian tafsìr on polygamy, qawwäm and nushüz-

the examples of Hamka and Quraish Shibab

Noorhaidi Hasan

Debating gender, women, and Islam:

Indonesia's marriage law of 1974 revisited

Muhrisun Afandi

Apostasy as grounds in divorce cases and child custody disputes

in Indonesia

Saifuddin

Fatwa of the Indonesian Council of Ulama (MUI) on Ahmadiyah

and its impact on women and children

Claudia Derichs

Participation, legal discourse and constitutional rights -

the 'Allah' issue in Malaysia ....

Irene Schneider

Translational turn and international law:

gender discourses in the Islamic Republic of Iran

Imen Gallala-Arndt

Personal status law in Lebanon 
Friederike Wapler

Post-marriage law and public policy:

some remarks on how German courts deal with Islamic rules on divorce

Gunnar Duttge

Religiosity in Medical Law of the secular modern age

187

List of contributors

200 


\section{Introduction}

The articles of this volume are a collection of twelve selected and revised contributions of two conferences which were realized within the framework of cooperation between the Department of Arabic and Islamic Studies of the Georg-August-Universität Göttingen and the Sharia and Law Faculty of the State Islamic University Sunan Kalijaga in Yogyakarta. The cooperation project runs over three years and is titled "Islamic law, gender and civil society in Indonesia and Germany" (Islamisches Recht, Gender und Zivilgesellschaft in Indonesien und Deutschland). It is funded by the German Academic Exchange Service DAAD within its program "Higher Education Dialogue with the Muslim world" (Hochschuldialog mit der islamischen Welt).

Both joint conferences of the first year took place in 2013, the first from 22 to 24 May in Göttingen and the second from 19 to 21 November in Yogyakarta. The topics of the conferences were „Islamic gender discourse and legal thought," and „Religious Diversity and Identity: Negotiating State Order and Civil Rights" respectively. These interrelated topics were examined in depth during the conferences. Concern has been expressed with regard to Muslim women's legal status by reference to the rights to freedom from discrimination. Besides the issue of discrimination of women, that of the freedom of religion for Muslims has also stirred participants' concern. The main issue relates to criminalization of apostasy and legal status of minority groups in Muslim societies. The title of this volume mirrors debates surrounding these topics although putting emphases on gender discourse and civil rights.

Although most of the articles focus on issues related to Indonesia and Indonesian Islam the topics are not confined in terms of time and place. Articles on [analogous] discourses in and on other countries and societies as Iranian, Lebanese, Malaysian and German broaden the picture on contemporary Islamic gender discourses and civil rights and laws.

The authors' scholarly approaches are manifold. They comprise theological approaches (Hamim Ilyas, Syafiq Hasyim and Saifuddin), social sciences (Claudia Derichs, Siti Ruhaini Dzuhayatin, Muhrisun Afandi), discourse studies (Irene Schneider, Noorhaidi Hasan, Fritz Schulze, Imen Gallala-Arndt) and law (Friederike Wapler, Gunnar Duttge). Of course, these approaches cannot be separated absolutely, and we can find many interfaces between two or even more of them.

Hamim Ilyas discusses the question whether the literal understanding of provisions given by the Qur'an and the Prophet concerning gender issues is a valid approach or not. Since gender provisions are widely believed to be an indispensable part of the Islamic sharia, the understanding and interpretation of sharia takes centre stage. Hamim Ilyas argues that shari'a must be seen in the wider context of the reli- 
gion as a whole and may not be reduced to a static and uncontextual fiqh. The concrete provisions have to be seen as a tool to achieve the ultimate goals of a religious and prosperous society and are therefore prone to changes in time and place. Provisions which had been beneficial in the $7^{\text {th }}$ century for an Arabic traditional society must not necessarily be useful and just in a modern $21^{\text {th }}$ century Muslim society in Indonesia. Hamim Ilyas calls this understanding of sharia sharī a min al- 'amr which is directed to religion as "mercy for the universe" (rahmatan li-al- 'alaminn).

Syafiq Hasyim points out a similar direction when questioning the development of Qur'anic and prophetical tafsìr concerning gender questions. According to his opinion this was hampered in history by a male bias. Patriarchic societies produce patriarchic interpretations. Interpretations of the Qur'anic verses are no exception to this. Male-oriented provisions based on such interpretations of gender issues ( $f i q h$ $a l$ - 'abaw $\bar{\imath}$ ) have to be replaced by a woman-oriented interpretation (fiqh al-nis $\vec{a}$ ').

Siti Ruhaini Dzuhayatin analyzes the Muhammadiyah's attitudes towards gender issues by contextualizing them in time and place. She draws a line from the founding of the organization until modern times. Muhammadiyah's views on women's role in family and society were determined by the social context of its Javanese constituency. At the time of founding it was the santri-priyayi environment of Yogyakarta which was crucial for the formation of Muhammadiyah's Islamic religious ideology. This attachment to social structures remain true until the modern times.

Fritz Schulze points out that some modern 'ulama $\bar{a}$ ' in Indonesia, namely Hamka and Quraish Shihab, produce some kind of Islamic counter discourse. They are well aware of the contemporary discussion on gender equality which is heavily determined by human rights issues. Nevertheless, they obviously don't accept the involved arguments and put the traditional fiqh arguments pertaining to polygamy, qawwām and nushüz against and above them, detached from time and place. By doing this they separate the two spheres of discourse, Islamic and national, whereas these two discourses should be intertwined to develop a national dialogue without creating unbridgeable cleavages in society.

Noorhaidi Hasan discusses Indonesia's marriage law of 1974. This law has created much controversy. The law itself was some kind of compromise between secular and religious interests. As such it left many questions open. Several attempts to revise the law have failed so far although the need for change is imminent. Some regulations are obviously not in harmony with modern human rights issues including among others the questions of interreligious marriages, divorce, the minimum age of marriage and so on. The reform of the law is difficult because the positions of some proponents remain incompatible.

Muhrisun Affandi's article touches on a related topic. Apostasy as valid ground for dissolution of marriage and child custody disputes in Indonesia is very much linked to positions on marriage, family and custody. Apostasy is often used as a reason for divorce. It is an often used practice to get married because to be properly married both grooms have to be of the same religion. In case of divorce it is easy to blame the spouse not to be a "real" Muslim. The judge of the Islamic Court will 
easily annul the marriage based on this assumption. Usually the children of such couples will be given to the Muslim partner. This practice shows that in child custody cases it is not the best interest of the child that matters, rather the religion of the parents. To ensure the religion of the child is the most important consideration. In this respect the Indonesian judicature is often at odds with human rights and modern secular influenced legislation.

Saifuddin uses a theological approach when discussing the fatwa of the Indonesian Ulama Council (MUI) on Ahmadiyah. In 2005 the MUI declared the Ahmadiyah as heretical. Saifuddin argues that the decision of the MUI is not right because the doctrines of Ahmadiyah are not against Islam and Islamic sharia. According to Saifuddin the MUI politics has only created harm not only for the Ahmadiyah adherents but also for the Muslim community at large as well as social peace in the country. In his view the MUI acted in its own interest or under the influence of Wahhabis. The worst affected are the women and children of the Ahmadiyah who are harassed just because of their religious affiliation.

Claudia Derich's article leads us to one of Indonesia's neighbours, i.e. Malaysia. The year-long debate on the usage of the word Allah by Christians and at last its prohibition is much more than a quarrel over a specific term. It tells us even more about the development of the reason of the Malaysian state. The policy of the Malaysian UMNO-government to abolish the usage of this word for its Christian community is one step on Malaysia's way to an Islamic state where other religious minorities have to succumb to the interests of the Malay-Islamic majority. By this the plurality of the Malaysian society is put at stake.

Irene Schneider describes and discusses the contemporary Iranian debate concerning women's rights and human rights vis-à-vis international conventions and the international discourse. She analyzes how the global discourse is translated into the Iranian context. Such a translation is without any doubt true for every contextualization. But within the Iranian framework it is interesting how the usage of specific wordings is adapted to the values, concepts and frames of the nowadays dominant Islamic-Shiite elite of the country. By redefining core terms it is possible to reject the very heart of the conventions and manipulate its contents.

Imen Gallala-Arndt provides an inside view into the Lebanese personal status law. The situation in Lebanon is clearly very specific and in parts dates back to Ottoman times. It is characterized by a high autonomy of diverse religious communities of the country. This bears some problems for the modern nation state because it results in a fragmentation which makes it very difficult for the state to exercise and even create its authority vis-à-vis the communities.

With Friedrike Waplers article we turn to the situation in Germany. Although a secular state with a Christian past, German law is concerned with Islamic law as well. In cases of personal law the German judiciary is obliged to use principles and regulations of the law of the home countries of foreign citizens. That means in cases of divorce, for instance, German judges use Iranian law and so on. This is a complicated task because the foreign regulations may not violate the German ordre public. 
For judges this means a high degree of understanding foreign law systems and their compatibility with German ordre public.

Gunnar Duttge shows that medical law has religious implications as well. The ethical provisions of religious communities may cause ethical problems when touching the borderline between the right of self-determination, the obligation of the physician to help, and raison d'état. This problem came into the spotlight when a German judge judged the circumcision of a young male as unlawful. Such a surgical intervention would be outlawed because of the lack of medical indication. Nevertheless, the German parliament paved the way by establishing a new law although parts of the German public were against because they interpreted it as a special law for the Jewish and Islamic communities.

The framework and rich material assembled in this volume will broaden our understanding of Islamic gender discourse and relevant legal issues among Muslims across the world. It offers a comparative framework of how the discourses are at work to inform the dynamics of sharia via-à-vis national laws in different - political, social, and cultural - contexts.

Noorhaidi Hasan

Yogyakarta und Göttingen, August 2015

Fritz Schulze 


\title{
The concept of sharia in the Qur'an and its relevance with gender discourse
}

\author{
Hamim Ilyas
}

\section{Introduction}

Islamic sharia is often misunderstood. Muslims have two common views on it. The first views sharia in a narrow understanding as law containing rules and regulations. The second views sharia in a broader scope which includes faith, morals, and law as well. Nevertheless, I argue that both views are not the proper meaning of Islamic sharia. Verse 18 of süra al-Jāthiya in the Qur'an mentions a term sharī a min al'amr. From its interconnectedness (munāsaba) to other verses, sharī a min al-'amr might mean a culture formed by Muhammad, thus it becomes a framework of Islam as "mercy for the universe" (rahmatan li al-'alamin) which he preached. In this paper I will explore the meaning of shari a min al-amr in that verse based on its relation to other verses. I wish the exploration of this concept will give strong theological basis to understand the dynamics of Muslims vis-a-vis current issues pertaining to gender and human rights.

\section{The Qur'an on sharia}

In the Qur'an, the foundation to determine a way to stand on is sharia. Since the foundation is a culture, sharia thus becomes a cultural framework of Islam as rahmatan li al-'álamin. As a cultural framework, sharia coming from Allah teaches belief, ideas, values, rules and regulations which determine a way the Umma should stand on to create a good life. In cultural perspective, a good life does not merely mean belief, ideas, and values; but also behavior and activities. Therefore, sharia which theologically comes from God becomes a good culture in the social life of the Umma. Nevertheless, because people usually understand culture as a product of human thought, perception, and intention, it is important to note that belief, values, rules and regulations in the sharia come from God. Humans do not create but only follow it. As for their behavior and activities, humans produce them according to their thought, perception, and intention.

The sharia as a cultural framework can be referred to according to the Qur'an in sūra al-Jāthiya (45) verse 18 as follows: 
And now have We set thee (O Muhammad) on a clear way of (Our) commandment; so follow it, and follow not the whims of those who know not.

In this verse, there are four indications of sharia as a cultural framework. First, "And now have We set thee (O Muhammad) on a clear way...". We have explained previously that sharia comes from God. This is known from the use of the phrase "have We set thee on ..." and not the phrase "We send down sharia to you" in the verse. This phrase shows that to be included in sharia, the Prophet Muhammad was actively involved going through certain processes in it and was not suddenly confronted with it without any participation at all. This is similar to the creation of humans into several races and tribes as mentioned in the Qur'an sūra al-Hujurāt (49): 13 which also uses the phrase "have We set...". To become blossoming out into races and tribes, humans actively participate in that process by carrying out marriage, procreation, and defending themselves from any dangers that threat their existence in the world. From the perspective of sociology, the process that the Prophet went through in the formation of sharia is called internalization and socialization. He accepted relevant sharia values and norms to build a better life under the framework of Islam as rahmatan li al- 'âlamīn. He then managed his attitudes and behavior to be in accordance with the goal to build a good life as part of his prophetic objectives.

Second, "a clear way of (Our) commandment (sharī'a min al-'amr)". This phrase shows, as described below, that sharia in which the Prophet is involved is extensive. Its extensity includes all dimensions of life. Therefore, sharia is not only about law as currently understood. The understanding of sharia as law in fact is only a part of the manifestation of sharia as an institution in culture.

Third, "so follow it (the sharia)". The Prophet was the most faithful person to God and becomes the model for the Umma in piety and fidelity. The Prophet thus carried out His command to follow the sharia of everything. In carrying out his duty, the Prophet ought to use relevant methods which fit to prophetic objectives to build a good life. Aisha, the Propeht's wife, witnessed that his morals is the Qur'an, and the Qur'an says that good deeds are the only way to build a good life. Therefore, the method to build a good life is piety. Piety, which is the opposite of destruction (fasād) and bad (sayyi'a), is an ethic-constructive method which fits to the moral norms and is effective to build a good life in all aspects such as social, education, law, politics, economy, etc. The use of this method was clear at the time of fath alMakka (the victory over Mecca) when the Prophet won his hometown peacefully. Instead of using the method of social conflict interaction, violence and coercion, the Prophet used the method of non-violence accommodation and peace by granting general amnesty to all Mecca inhabitants including his enemies who wanted to kill him and to invade Medina to exterminate the Umma. This proves that the Prophet creates a good example of social interaction for the Umma so that they may develop into a great community which contributes to the development of human civilization.

Fourth, "and follow not the whims of those who know not". Referring to his fidelity, the Prophet must not follow his personal desire as well as group interests to 
deviate from the sharia. The prohibition in this verse directly indicates to the deviation from the implementation of the sharia. For instance, at the time of fath alMakka, there was a daughter of a noble family who stole something and her family begged the Prophet not to punish her. Yet the Prophet refused to do so and, according to the sharia, decided to cut her hand as punishment. In addition, the prohibition also relates to the result of the implementation of the sharia. This means that the implementation of the sharia may not destroy anything needed to build a good life; instead it should result in goodness or perpetuate it to improve the life of the Umma. For example, the Prophet prohibits anyone to destroy a building in war, or suggests Muslims to brush their teeth using siwāk when taking ablution or before salāt. These prohibitions and suggestions show that the Prophet did appreciate a material form of culture.

\section{Sharī' a min al-'amr: a good way of life}

The sharia as a cultural framework for Islam as rahmatan li al 'âlamin in the Qur'an sura al-Jāthiya 45 verse 18 is formulated in the concept sharī'a min al-amr. This concept consists of three words whose meanings contain among Qur'anic interpreters, to some extent, differences. These are some citations from Qur'anic interpreters on the meaning of sharī a min al-amr. Țabarī gives its meaning as "a way, a way everyone must take and a system that contains commands that We (God) have commanded to prophets before you (Muhammad)"1; Ibn Kathīr says "whatever God reveals to you"2; Zamakhshari says "a way and a system in the form of religious commands" ; Jalalayn and Bayḍaw say "a way in the form of religious commands" ; and Abū al-Su'ūd says "a way everyone must take, an important and glory way in the form of religious commands". 5

Beside the concept of sharia, the Qur'an also contains the concept of shir ' $a$ (and minhaj) to refer, as Jalalayn said, to "a way in the form of religious commands". Sura al-Mä̀ida (5) verse 48 says:

And unto thee have We revealed the Scripture with the truth, confirming whatever Scripture was before it, and a watcher over it. So judge between them by that which Allah hath revealed, and follow not their desires away from the truth which hath come unto thee. For each We have appointed a divine law and a traced out way. Had Allah willed He could have made you one community. But that He may try you by that which He hath given you (He hath made you as ye are). So vie one with another in good works. Unto

1 Al-Ṭabarī 2005, XXV: 169.

2 Ibn Kathīr 1996, IV: 149.

3 Al-Zamakhsharī (n.d.), III: 511.

4 Al-Suyūṭ̂̄ and al-Mahallī (n.d.), II: 409; al-Baiḍāwī 2006, II: 388.

5 Abū al-Su'ūd 1999, VI: 60. 
Allah ye will all return, and He will then inform you of that wherein ye differ.

When Arabic linguists explain the meaning of sharia, they also refer to shir ' $a$ and its variants such as shar' and shir 'by explaining their forms, and their linguistic as well as terminological meaning. Ibn Manzūr argues that sharia is not a formative word and its linguistic meaning is a place in a seashore where animals drink. Together with shir' $a$, sharia is used to refer to the religion of God and people are ordered to carry out its commands such as daily prayer, fasting, pilgrimage, charity, and other good deeds. ${ }^{6}$ This use, according to some 'ulamä', is for tashbīh (resemblance) because religious sharia resembles sharia (well) in the meaning that people who come into it in a right way will be fresh and clean. ${ }^{7}$ Al-Ișfahānī says that sharia is formed from the word shar' which means a clear path way (nahj al-țariq al-wādihh). Sharia is then synonymized to shir and shar' which are used to refer to a path way (al-tariq al-nahj). Those three synonymized words are used as a metaphor for a way of God (al-țarīq al-'ilāhiyya). ${ }^{8}$ As a way of God, Ișfahānī argues, sharia includes two meanings. First, a way that God establishes for humans to obediently take it in order to create their benefits and state prosperity. Second, a religion that God institutes and people are ordered to carefully follow by choosing the right teaching according to their religion (because there are differences among religions). ${ }^{9}$

The above exploration from Qur'anic interpreters and Arabic linguists shows that sharia and religion (dīn and milla) have the same meaning. Al-Jūrjānī acknowledges this similarity, yet he argues that the use of both words may not be interchanged because they have different stressing. Sharia, he argues, is religious provisions; din is obeyed sharia; and milla is a sharia which assembles religious followers as an Umma or a jamā ' $a{ }^{10}$ Differently, Muhammad A' lā al-Tahānawī asserts that shar 'or sharia is similar to religion (din and milla). Quoting from Yusuf Mūsā, al-Tahānawī explains that sharia is everything God establishes for His servants in the form of provisions taught by a prophet. These provisions include deeds called far iyya (branch) and amaliyya (practices) mentioned in the fiqh; and also faith called 'așliyya (principles) and i'tiqädiyya (beliefs) which is discussed in kalām. ${ }^{11}$ Yusuf Mūsā seconds al-Tahānawī's explanation who then insists on the similarity of sharia and religion (dīn). According to Yusuf Mūsā, sharia is a religion God establishes for Muslims, either based on the Qur'an or the Prophetic traditions. Therefore, sharia includes faith ('aqìda), morals (akhlāq) and law (fiqh). ${ }^{12}$

6 Ibn Manẓūr 1997, VIII: 176.

7 Al-Ișfahānī (n.d.): 265.

8 Ibid.

9 Ibid.

10 Al-Jūrjānī 1971: 56.

11 Yusuf Mūsā (n.d.): 10.

12 Ibid.: 9. 
Based on all exploration from the above mentioned 'ulama', there are two important things in the formulation of sharia as the cultural framework for Islam as rahmatan li al- 'älamīn. First, sharia is a way of religion. In al-Ta rïfät, besides explaining the aforementioned meaning of sharia, Al-Jurjāni also states its meaning as "carrying out all commands by consistently serving God" and "a way of religion (altarīq fì al-dīn)". ${ }^{13}$ 'Abd al-Mun 'im al-Hifnī follows al-Jurjānī’s statement. ${ }^{14}$ Second, sharia contains commands (al-'amr) and provisions (al-ahkām) in faith ('aqīda), morals ( $a k h l \bar{q} q)$, and law (fiqh). Thus, sharia contains not only law as fiqh but defines it as "provisions concerning humans deeds established by religion". 15

Explanations about the nature of sharia as a way of religion containing those three aspects must be related to the meaning of sharia as a path way (al-tariq alnahj). According to these explanations related to the linguistic meaning of sharia, sharia means a way which has three paths: faith ('aqi $\bar{l} d a$ ), morals (akhläq), and law (fiqh). Muslims who follow sharia must carry out all those three paths. It is not sufficient to take only a part of it. Because of its nature and contents, at-Tahanawi and Yusuf Mūsā when defining sharia propose a limitation "God has established" for "provisions and religion". The limitation "established" means that "provisions and religion" is "established as the way by God".

If we trace further the explanation of sharia, which is identical with religion which consists of the three aspects faith ('aqida), morals (akhlāq), and law (fiqh), it is, in fact, grounded in the interpretation of al- 'amr in the concept of sharī 'a min al'amr mentioned in the Qur'an, süra al-Jäthiya (45): 18 that contains religious commands and revelations commissioned to the prophets before Muhammad. This interpretation seems to be based on the use of the word shara ' $a$ in the Qur'an to declare a religion for an Umma. For Muslims, the use of it is mentioned in the Qur'an süra alShūra (42): 13; and for Arab polytheists is in süra al-Shūra (42): 21. Because in both verses the verb shara' $a$ is used for declaring a religion, the noun shari ' $a$ or shir ' $a$ is understood as a declared religion.

However, the use of al- 'amr as such is not in accordance to the munāsaba (interconnectedness) of the verse al-Jāthiya (45): 18 to previous verses in the same süra, especially from verse 16 whose discussion cannot be separated from verse 18 . In verse 16, God asserts that He has granted the Children of Israel a scripture (al-kitāb), commands (al-hukm), prophethood (al-nubuwwa), good livelihood and prosperity, and favours them over other people. In verse 17, God has granted them bayyināt min al- 'amr, plain commandments. Because both verses talk about the Children of Israel, the understanding cannot be separated. Thus, $a l$ - $a m r$ in verse 17 is the five aspects mentioned in verse 16. Besides granting those five gifts (scripture, etc.), God also gives the Children of Israel clear proofs that He has already given them those five gifts. In verse 18, God has set Muhammad on shari' a min al- 'amr, a clear way of 
commandment. The understanding of verse 18 should not be separated either from the previous verses. What is meant by al- 'amr then is al- $a m r$ as mentioned in the previous verse, namely the five gifts granted to the Children of Israel. If those three verses are understood comprehensively as a unity, the sharia taken by the Prophet Muhammad under the guidance of God is the way of scripture (al-kitāb), commandments (al-hukm), prophethood (al-nubuwwa), good livelihood and prosperity, and favorable over other people. Also, if then min al-'amr is still understood as religious commandments, thus the religion meant is the religion which includes those five aspects.

This understanding fits to the use of the conjunction "thumma" (then) in verse 18 which indicates the order of time with long interval. The Children of Israel who were the descendants of Abraham from his son Isaac, have received the scripture from the time of Isaac more than 2000 years BCE and through a long process received the other four gifts as well until the five things they have received were completed. The Prophet Muhammad who was a descendant of Abraham from his son Ishmael just received the scripture (al-kitāb) in the beginning of the seventh century CE. There is a time interval of more than 2700 years between the scripture revealed to Muhammad and the one to the Children of Israel before.

Those five gifts had been granted to the Children of Israel. The verses 16-17 of süra al-Jāthiya (45) clearly declared that "verily We gave" and "We gave them". For Muhammad and his Umma, those five gifts were still in the process of obtaining them completely. Therefore, verse 18 of the same süra states "And now have We set you on sharia...".

Following are brief descriptions of the five gifts granted to the Children of Israel and then "granted" to the Prophet Muhammad. First is the scripture (al-kitāb). Al$K i t a \bar{b}$ are written revelations sent down to several prophets. The prophets of the Children of Israel from Joseph to Jesus have received three scriptures: Torah, Psalms, and Bible. The Prophet Muhammad also received a revelation which was then written in a book called the Qur'an. All the scriptures as God's revelation teach three aspects: Oneness of God (tawhìd), rituals (ibāda), and morals (akhlāq).

The sccond is commandment (al-hukm). What meant al-hukm here actullay is not law. The Qur'an süra al-Qașaș (28) verse 14 states that God granted "hukm" to Moses, a prophet of the Children of Israel. The hukm here means power and leadership. This is because God granted Moses the hukm before He commissioned him as a prophet, yet he at the time was a very influential young man among the Children of Israel under the oppression of the Pharaoh reign. We learn from history that the Children of Israel were known as people who exercised political power both in Palestine and outside the area. David and Solomon were very successful king-prophets in Palestine; meanwhile Joseph was a very successful statesman in Egypt. To Muhammad in Mecca when süra al-Jäthiya was revealed ${ }^{16}$, al-hukm means that his

16 In the chronology of Egyptian mushaf, al-Jathiya is the $65^{\text {th }}$ sura from the Meccan period. It was revealed at about the eighth year of Muhammad's prophethood. See further Amal (2001): 96. 
leadership was acknowledged by his followers and was well-thought-of by his enemies. The history then proves that Muhammad's leadership was very effective to bring about glory especially for the Arabs and for the Muslims in general.

The third is prophethood (al-nubuwwa). The Children of Israel had several prophets. Among the 25 prophets in which Muslims have to believe, eight of them came from the Children of Israel. They are Joseph, Moses, Aaron, David, Solomon, Zachariah, John and Jesus. These prophets were righteous people and glorified the civilization of the Children of Israel. As for Muhammad, he acted as a pious man who built the Islamic civilization through the concept of 'iqra'.

The forth is good livelihood and prosperity. The Children of Israel had expertise and skills in several aspects of economy which helped them live prosperously. The story of Joseph and Moses illustrates well how the Children of Israel brought off agriculture with good irrigation. In Medina at the time of the Prophet Muhammad, Jews dominated the sector of industry especially in manufacturing gold, silver, and steel. Muslims had to order war equipment such as swords and shields to the Jews who worked as blacksmiths. When al-Jāthiya was revealed, the Prophet Muhammad gained a lot of benefits from commerce. In Islamic history, commerce has become not only good livelihood which brought about prosperity among Muslims, but it also has become a da'wa media to spread Islam.

The fifth is superiority over other people. Under the guidance of the prophets who built their civilization, the Children of Israel then were in a favorable position and had superiority over other people. This is because their prophets carried out their mission very well including building the civilization with knowledge of development and technological innovation. For instance, Moses invented the technology of constructing wells which gave to the Children of Israel skills and abilities in water engineering. At the time when al-Jăthiya was revealed, the Prophet Muhammad had spiritual and moral superiority for which his people admired him and awarded him the title al- 'amin, the trustworthy. He was also known for his firm stand to defend basic principles and values although he received several and simultaneous harassments and threats. In addition, he was an example, to some extent, in physical civilization with cleanliness, elegance, health and hygiene in his daily life. The physical civilization the Prophet performed in the beginning era of Islam in turn inspired following Muslim generations to build clinics and hospitals.

In the perspective of culture, those five aspects might be called the elements of culture in term of:

1. System of faith and rituals as manifested on al-kitāb in the form of faith, prayers, and rituals;

2. System of social organization as manifested on $a l-h u k m$. It functions as social control and leadership to influence people achieving the vision, mission, and objectives of the society;

3. System of knowledge as manifested in al-nubuwwa. The prophetic mission was to build a civilization through right, accurate, and appropriate knowledge; 
4. Language as also manifested in al-nubuwwa. The prophets carried out their mission using the language of the people in order to be easily accepted and understood (Q.S. Ibrahim (14): 4);

5. Fine art as manifested as well in al-nubuwwa. The prophets built civilizations to some extent - using media of fine art, such as Adam created a clothing style and Hud developed architecture;

6. System of way of living as manifested in good livelihood and prosperity through commerce, industry, agriculture, life stock, etc,;

7. System of technology and tools manifested in the superiority over other people especially the technology of water engineering; gold, silver, and steel manufacture; etc.

From the above explanation it is clear that the sharia the Prophet Muhammad went through is a good way of life in a cultural framework. This fits to the basics of Islam as rahmatan li al-'alamin: Allah whose main attribute is blessing (rahma), the Prophet Muhammad was commissioned as blessing (rahma), the Qur'an was revealed also as mercy (rahma). Islam as rahmatan li al- 'älamin strives for a good life, not only for Muslims, but also for all human beings and the universe as well, both in this worldly life and in the hereafter. A good life cannot be achieved without a good culture. With a good culture, humans as individuals and society go through all complexities of life. This is why a way to go through a good life with a good culture mentioned in the Qur'an sūra al-Jāthiya (45): 18 is called sharī a min al'amr, a way of all life matters.

Life matters are complex. Yet with all its complexities, those matters can be culturally explained with the seven elements of culture aforementioned. Therefore, people, whatever their religion, who strive for a good life must improve those seven elements comprehensively. Muslims who wish for a good life on an Islamic basis have to develop their theology and religiosity within those elements of cultural framework.

Sharia as a cultural way is currently reduced to a path of law. With this reduction, the sharia is, of course, not able to be a way to accomplish a good life. If sharia is implemented by its three elements - namely faith ('aqīda), morals (akhlāq), and law (fiqh) - as commonly understood, it might not be able to accomplish a good life either for it does not provide a clear and comprehensive path of the way. To make the sharia able to accomplish a good life, it must become shari' a min al- 'amr consisting of five formulations which include the seven elements of culture. The sharia thus includes a system of faith and rituals; a system of social organization; a system of knowledge; language; fine arts; a system of livelihood; and system of technology and tools.

From its linguistic root, it is the sharia which contains those five paths or seven systems that can be called sharia. Following Ibn Mandhur's idea which explains that the original meaning of sharia is a place on seashore where animals drink, going through the sharia which contains those five paths or seven systems can expunge 
people's longing for spirituality, good economy and politics, etc. Similarly, following al-Ișfahānī's idea which states that the original meaning of sharia is a clear path of way, the sharia which contains those five paths or seven systems can really become a clear way to go through a good life according to God's will revealed in the Muhammad prophetic mission and the Qur'anic revelation. Since it really becomes a clear way, it is called sharia which comes from the word shar "with the additional letters " $y a$ ", and "ta'marbüta". It is not sufficient to add the "ta'marbüța"only. In Arabic language, "ta'marbüta" is added to a noun to indicate simultanity or repetition (al-tikrār). Shar' complemented with "ta'marbüța" becomes shir' $a$ which means a path way that is simultaneously and repetitively gone through. It is the way that people take to go through their life, especially in the early development of their society. Furthermore, the letter " $y a$ " " can be added to a noun to indicate an attributed quality or a quality that is intrinsically present within something designated by the word. Sharia is shar " to which is added " $y a$ " " and "ta 'marbüta". This means that sharia is the proper way to be taken simultaneously in order to go through a life because anyone who takes it will live a good life. The sharia deserves it because it becomes a way that has clear and complete paths and systems. This is the meaning contained in the additional letters of " $y a$ " " in the word sharia which is in the religion preached by the Prophet Muhammad because it completes the religion of isläm preached by all prophets from Adam to Jesus before the coming of Muhammad's prophethood.

Such understanding of sharī 'a min al-'amr means that sharia consisting of five paths or seven systems had been possessed by the Children of Israel in the past. Since they possessed it through a long process for more than 2000 years under the guidance of their prophets, in the perspective of the Qur'an süra al-Ma'ida (5): 18, what they possessed is called minhaj. Minhaj (nahj), according to the terminological meaning based on shar' as explained by al-Ișfahānī is a way in its broader meaning (nahj al-țariq al-wādih). ${ }^{17}$ The way consists of clear and unclear paths. The clear path includes what so is called sharia, that is a clear path containing all the five paths or seven systems completely; and shir $a$, that is a clear path containing only parts of those five paths or seven systems.

The way the Children of Israel went through is called minhaj because in certain periods they only developed parts of those five paths or parts of those seven systems. For instance, at the time of Moses, they only developed a system of law as a part of the system of society; and the system of technology and livelihood by engineering water and agriculture. However, at another period the Children of Israel also used to develop all those five paths or seven systems completely such as what they have done under the guidance of the king-prophet Solomon.

Meanwhile, the way the prophets before the period of the Children of Israel went through in the perspective of verse 18 from süra al-Ma'ida (5) is called shir ' $a$. This is because they used to take the way with clear paths, but they only developed parts

17 Al-Ișfahānī (n.d.): 265. 
of those five paths or seven systems. For instance, Adam only developed the system of faith; the system of livelihood; and the system of social interaction by introducing the culture of clothing.

Therefore, Muslims and the Umma, based on verse 18 of sūra al-Jāthiya (45), are actually commanded to follow the sharia which constitutes the minhaj with the complete five paths and seven systems and leave out the shir' $a$ which is actually the minhaj with incomplete paths. In the perspective of history, this understanding, in fact, is appropriate to comprehend a claim of eradicating sharia proposed by few 'ulama'. This means that people who currently go through the shir' $a$ and minhaj with incomplete paths - for instance they only develop the system of faith and the system of law - they in fact follow the abrogated shir ' $a$. The shir' $a$ is abrogated because it fits only into the period before Jacob - with the assumption that the Children of Israel started with Jacob, son of Isaac, son of Abraham - or perhaps earlier before the period of Abraham who lived around $2500 \mathrm{BCE}$, when the civilization of a settled life was not firmly established yet.

\section{Some implications on gender discourse}

In the Islamic movement develops a claim that Islam is a religion that conforms with all periods and places (al-Islām șālih lì kulli zaman wa makān). Because there is no clear framework, this claim has become apologetic and has not any moral and social significance. The acceptance of sharia as cultural framework for Islam as rahmatan li al- 'alamin as explained before can fill the lack of a theoretical basis of the claim. With this framework, the conformity of Islam with all periods and places is determined by its ability to be a dynamic, applicable, and improving religion. To make the conformity real, these three indicators must exist in the implementation of all Islamic teachings, including the implementation of a just gender relation teaching in the modern and democratic society which is of course different from its implementation in the traditional-patriarchal society in the past.

Muslims all over the world until early $21^{\text {st }}$ century commonly still lived in traditional societies which mostly practice patriarchal gender relations. As history moves forward, Muslims must gradually transform into a modern society so that they have to apply democratic gender relations. Therefore, they must start thinking to reconstruct gender relations that fit to contemporary needs.

The reconstruction to create a just gender relation has to be based on adequate ethic principles. In Islamic law, Muslim thinkers have developed traditions of formulating basic principles of law which actually constitute moral principles on which formulated rules and regulations have to be based. For instance, in Islamic economic law (mu'ämalāt), there is a formulation of basic principles of law which consists of al-taradì (autonomy), 'adam al-gharar (fairness which includes honesty and justice), 'adam al-ribā (no harm, no exploitation, and no violation to people's rights), 
and 'adam al-maysir (moral integrity). Thus, the gender reconstruction must base on ethical principles that fit to the Islamic traditions.

In addition, in order to supply a strong theological basis for the gender reconstruction, Qur'anic verses and Hadith traditions whose misogynic literal meanings do not conform to a just gender relation need to be reinterpreted. To avoid resistance, the reinterpretation of those Qur'anic verses and Hadith tradition must apply an undisputable paradigm which constitutes fundamental views on the Qur'an and Hadith presented by the Qur'an itself. It is the paradigm of the Qur'an as the Book of Mercy (rahma) as stated in the Qur'an sura al-Qașaș (28): 86 and süra adDukhān (44): 6; and Hadith as the text of mercy ( rahma) as mentioned in the Qur'an süra al-'Anbiyā' (21): 107. The application of this paradigm will consequently reject the literal reading because injustice is not rahma (mercy, real virtue) intended by God and the Prophet Muhammad.

Furthermore, the gender reconstruction needs to be formulated into rules and regulations so that its implementation can be coerced by the state and a just gender relation becomes social reality. According to the tradition of formulatic basic principles of law, the legislation of a just law in respect of gender must be based on adequate ethical principles. Regarding this matter, I have already formulated ethical principles that can be used as the foundation of family law which includes the principles of autonomy, honesty, justice, love, and brotherhood. ${ }^{18}$ With these principles, Islamic family law ethically becomes an effective and virtuous law which can assure the principles of equality, liberty, and solidarity among humans as characteristics of modern law.

\section{Conclusion}

The Islamic Umma experiences a multidimensional crisis and is relatively left behind Chinese-Tao and Indian-Hindu which, to some extent, successfully transform from an agrarian into an industrial society. The understanding of sharia as cultural framework might become the theological basis to improve the life for the Umma. With that understanding, Muslims must develop Islamic doctrines and practices which include all systems that constitute the elements of culture that fit to the time they live in contemporarily. It is a modern culture that - according to Tariq Ramadan - includes principles of modernity such as rationality, change, and independence. ${ }^{19}$ The development of Islamic doctrines and practices conforming to these principles, including in the construction of gender relation, is a proper implementation of sharia to currently pursue the vision of Islam as the mercy of the universe (raḥmatan lì al- 'àlaminn).

18 Ilyas: $1-4$.

19 Ramadan 2003: 1. 


\section{Bibliography}

Amal, Taufik Adnan (2001): Rekonstruksi sejarah al-Qur'an. Yogyakarta: Forum Kajian Budaya dan Agama.

Baiḍ̂̄wī, al- (2006): 'Anwār al-tanzīl wa 'asrār al-ta' wōl. Bayrūt: Dār al-Kutub al-'Ilmiya. Hifnī, 'Abd al Mun'im al- (1990): Al-mu 'jam al-falsafí. Al-Qāhira: al-Dār al-Sharqiyya. Ibn Kathīr (1996): Tafsīr al-Qur'ān al- 'aḍ̄m. Bayrūt: Mu'assasa al-Kutub al-Thaqafiyya. Ibn Manzūr (1997): Lisān al- 'arab. Bayrūt: Dār al-Fikr.

Ilyas, Hamim: Al-Qur'an dan etika perkawinan dalam Islam; to be published in a book entitled etika sosial interaksi lintas agama by Globethic.net, Genewa.

Ișfahānī, al- (n.d.): Mu jam mufradāt alfăz al-Qur'ān. Bayrūt: Dār al-Fikr.

Jūrjān̄̄, al- (1971): Al-ta' rīfăt. [Tunis]: al-Dār al-Tunisiyya li al-Nashr.

Koentjaraningrat (2002): Kebudayaan, mentalitas dan pembangunan. Jakarta: Gramedia.

Mūsā, Muhammad Yūsuf (n.d.): Al-madkhal li dirāsa al-fiqh. Al-Qāhira: Dār al-Fikr al'Arabī.

Qunaybī, Hāmid Șādiq (1985): Mu 'jam lugha al-fuqahā'. Bayrūt: Dār al-Nafā' is.

Ramadan, Tariq (2003): Menjadi modern bersama Islam. Bandung: Teraju.

Su'ūd, Abu al- (1999): Irshād al- 'aql al-salīm 'ilā mazāyā al-kitāb al-karìm. Bayrūt: Dār alKutub al-'Ilmiyya.

Suyūṭi and al-Mahallī, al- (n.d.): Tafsīr al-Qur 'ān al- 'ad̦ìm. Semarang: Thaha Putera.

Țabarī, al- (2005): Jāmi 'al-bayān 'an ta' wīl 'āy al-Qur'ān. Bayrūt: Dār al-Fikr.

Zamakhsharī, al- (n.d.): Al-kashshāf 'an haqā'iq al-tanzīl wa 'uyūn al-'aqāwīl fì wujūh alta wìl. Tihrān: Intisharāt Āfitāb. 


\title{
Gender, the problem of patriarchy and mașlaha in Indonesian Islam: from fiqh al-'abawi to fiqh al-nisä'
}

\author{
Syafiq Hasyim
}

Generally speaking, the term gender remains often misunderstood in Indonesia even by its committed adherents like me. The misinterpretations of gender range from making a joke to serious matters of our daily behavior, attitude and discourse on it. The people of Indonesia often identify gender with female or feminine gesture and behavior. You can feel more misconstruction and misunderstanding of this concept when attending Islamic forums and discussions, meetings of state officials and many other occasions in Indonesia. In short, gender is simply translated into all things physically and mentally related to women. All these reflect that the notion of gender remains discursively contested and to some extent misguided. The lack of proper understanding on the discourse and practice of gender in Indonesia is a result of complex intermingling between social, cultural and legal factors as well as malebiased interpretation of religion. The religion-based patriarchy becomes more apparent due to the literal fanaticism of Indonesians regarding their religion's views on the rights of women. For the literalist groups of Indonesian Muslims, the legal status of women in Islam is very clear as the subordinate of husbands and men both in the public and domestic sphere. This is seen as non-debatable because it is literally mentioned in the Qur'an, or qat ' $\bar{l}$ al-dilāla (cogent indication). From the perspective of the groups, following this role strictly is part of being pious and respecting the teachings of Islam. Hizbut Tahrir Indonesia (HTI, Party of Liberation, Indonesia) and also the women's wings of Partai Keadilan Sejahtera (PKS, Justice Prosperity Party) believe that all efforts to liberate women in Islam are part of an international conspiracy to de-legitimize Islam. Both organizations seem to hold the understanding that Islam determines the position of men as leaders for women both in the public and private spheres. This is one example of how Indonesian Muslims implement "patriarchal" perspectives, which are based on religion. This paper seeks to shed light on the problems of patriarchy, particularly those which are related to the preference of Indonesian Muslims in adhering to a particular discourse of Islamic legal theory and jurisprudence that creates ambiguity and tension with gender issues internationally. In doing so, I will depict the various Islamic interpretations used by Indonesian Muslims to publicly discuss the problem of patriarchy. This paper also highlights the dynamics of Muslim scholars and activists locally and globally in striving for this issue through their new method of interpretation such as mașlaha or 
maqāșid theory. A discursive shift from male to female oriented Islamic jurisprudence is also taken into account in this piece.

\section{Indonesian Islam and the state of patriarchy}

Historically speaking, Indonesian Muslims have long been recognized as open and respectful concerning the diversity and plurality of beliefs and religions ${ }^{1}$. Indonesian Islam is also often claimed as the best model of religious tolerance in the world. All these assumptions are based on factual cases of the religious life of Indonesian Muslims, including their preference to have a non-Islamic theocratic state although Indonesia is the most populous Muslim nation in the world. Most importantly, historical narratives on the coming of Islam to the archipelago serve as further evidence in support of this argument. It is, for instance, agreed among historians on Indonesia that Islam was not disseminated in this region through violence or war, but it came peacefully through trade and cultural means. Both ways have enabled Islam to spread wide and negotiate smoothly with the myriad localities of Indonesia. With regard to this fact, many experts conclude that Indonesian Islam has its own characteristics which are different from Islam in other places of the world especially the Middle East. The distinctiveness is mostly associated with a more flexible and accommodative nature of Indonesian Islam with regard to various local values and cultures of the country. Therefore, finally, it is believed that the Indonesian Islam gives more space and tolerance for innovation and reinterpretation of issues posed by modernity.

Derived from the given historical facts, Indonesian Islam is also comfortable with the rights of women because its inclusive character will also create room for respecting the equality of men and women. Judging the conformity of Indonesian Islam to the rights of women is not a simple matter. When the queens of Aceh (1641-1699) led that kingdom, Islamic legal polemics pertaining to the legality of a woman leading the state arose there. The local 'ulam $\vec{a}$ ' of Aceh seemed to be fine with the leadership of the Sultana (queen) but a fatwa by the sharif of Mecca stating that women were not allowed to lead the kingdom had more resonance ${ }^{2}$. Raden Ajeng Kartini, often credited as a modern female liberator in Indonesia, also suffered from the classical dictum of polygamy in Islamic legal jurisprudence ${ }^{3}$. So the inclusiveness of Indonesian Islam regarding the local values of Indonesia does not always mean it accepts the equal rights of women and men. It can be said that Indonesian Islam is comfortable with the diverse localities of the country, but has trouble dealing with women. This is the kind of patriarchal portrayal of Indonesian

1 Wieringa 2006: 1; Azra 2013.

2 Riddell 2007: 42; Kathirithamby-Wells 1976: 71.

3 Taylor 1976. 
knowledge including Islam in which all matters related to the body of women is not part of publicness.

The cases above paint a different picture than what the oral history of Indonesia often tells us, which is that Indonesia is a nation of mothers (ibu pertiwi). For example we can see positive historical examples of female queens, heroes, Muslim female scholars and many others, which are often cited to support this idea. Fatima Mernissi for instance discusses the leadership of the four sultāna in Aceh (1993) whose roles are often forgotten by the Muslim world especially by Indonesian Muslims. Female figures such as Kartini in Central Java, Dewi Sartika in West Java, Rohana Kudus in West Sumatra are celebrated by Indonesians regardless of their religion and gender. Although historical and sociological cases can be used as modality to construct "comprehensive values," to borrow John Rawls' term, of the modern political and legal structure of Indonesia to enhance the position of women, but our indigenous values instead often remain dominated by a "patriarchal discourse of Islam". 4

Politically speaking, since the era of independence, it is a telling fact that Indonesia has not yet ensured equal rights for its male and female citizens. Indonesia has not yet issued strong state policies that ensure men and women have equal rights and status in the public sphere. In addition, the modern state of Indonesia has conformed to unwritten legal and cultural rules and bureaucratic patterns which discriminate against women. The role of women is institutionalized and limited within domestic matters of the public sphere, such as the association of civil servant's wives (Darma Wanita) and many other similar groups. All these arrangements place women in a subordinate status. From the perspective of Marx and Engels, the state policy of the New Order era can be seen as a patriarchal state as all modes of production were made on the basis of "bondsmen". It is important to mention here that this discrimination is implemented through the state's laws, which do not grant equal justicc, fairness and protection for both men and women. Although the state for instance does not specifically differentiate between men and women in its laws, this does not mean that the state has fulfilled justice either for men or women. In the perspective of gender studies, taking a neutral stance can be regarded as disempowering or excluding women. When the situation of men and women are not equal because of the dominance of one sex and the state maintains silence on this issue, it can also be understood as discriminating against women.

Furthermore, Indonesian lawmakers have codified some patriarchal elements of Islamic law into the state law. Their crowning achievement was the codification of Islamic personal laws into a Presidential Instruction No. 1/1991 on Kompilasi Hukum Islam. Many Muslim scholars claim that the KHI is a strong example of Indonesian fiqh due to its accommodation of some concepts of Indonesian culture like harta gono gini, but in general, this compilation does not promote the equal status and rights of women and men. Starting from this deficiency, an attempt to

4 Rawls 2011; Weithman 2011: 305.

5 Murray 1995: 6. 
deconstruct the KHI was taken by a collaborative team consisting of a sub section of the Ministry of Religious Affairs (MORA), Muslim academia and Islamic NGOs. ${ }^{6}$ This project was led by a senior officer of MORA, Musdah Mulia (b. 1958). Mulia herself is an activist and Muslim feminist who started her career as a civil servant at the Ministry of Religious Affairs. Now, Mulia is one of the very brave Indonesian feminists who passionately struggle for not only women rights but also pluralism and religious tolerance in Indonesia. Mulia has become the target of stigmatization and victimization by radical Islamic groups in Indonesia for her role in attempting to promote women's rights. The project was intended to revise and make the content of the KHI more sensitive and empowering to the rights of women. But, the final document of this project was rejected by the MORA, which said the content was widely divergent from the mainstream fiqh of Indonesian Islam. A side effect of this rejection was that it was capitalized on by certain groups to brand all attempts at reforming Islam as part of a Western-designed plot to denigrate Islam.

\section{Progressive efforts of Indonesian Islam}

Since the reform era in 1998, there have been some legal improvements regarding the advancement of gender equality in Indonesia. Abdurrahman Wahid (known by his nickname, Gus Dur) issued an INPRES (Presidential Instruction) No. 9/2000 on gender mainstreaming. ${ }^{7}$ Although as a legal instrument, the INPRES does not have strong legal basis, but it provided a further means to promote women rights. This can be seen, for instance, in the quota of women's representation which was required in the state law on general elections in 2009. This law demanded all political parties achieve a $30 \%$ quota for women candidates in the parliament. However, although some progress was made in gender policy, at the same time, new patriarchal tendencies have emerged since the fall of Suharto. ${ }^{8}$ This can be seen from some Muslim's support for polygamous marriages, domesticating women's roles, endorsing female circumcision and many others. Islamic organizations such as the HTI, Forum Umat Islam (FUI, Islamic Socicty Forum), Majclis Mujahidin Indonesia (MMI, Mujahidin Defenders of Indonesia) and also Islamic parties such as the PKS are fighting for polygamy. They are very active in running media campaigns that polygamy is part of Muhammad's tradition (sunna). PKS has many ideas and agenda similar to these groups. Many prominent leaders of this party have more than one wife. Although some members of the party advocate the importance of having only one wife, this idea is rejected by the majority of the party. This can be seen, for instance, in Bahagiakan diri dengan satu istri, written by Cahyadi Takariawan. This book is

6 I personally got involved in this project.

7 Schech and Mustafa 2010.

8 Day 2006: 149. 
intended to internally persuade PKS cadres and activists to be monogamous and externally show that not all PKS members support polygamy. ${ }^{9,10}$

Puspowardoyo, an entrepreneur, advocates polygamy by providing a national prize for successful polygamous relationships. The HTI also mobilizes its followers to protest against the role of women in the public sphere because it is against women's responsibility in Islam as the mother of household. The Majelis Ulama Indonesia (MUI, Council of Indonesian Ulama) published a specific fatwa in 2008 declaring it unlawful to argue for the prohibition of female circumcision. The fatwa is called Hukum Pelarangan Khitan Terhadap Perempuan (Legal Judgment for Prohibiting Female Circumcision). ${ }^{11}$ The fatwa states "pelarangan khitan terhadap perempuan adalah bertentangan dengan ketentuan syari'ah karena khitan, baik bagi laki-laki maupun perempuan, termasuk fitrah (aturan) dan syiar Islam," (prohibiting female circumcision is against the regulations of sharia because circumcision, for male as well as female, is part of Islamic requirements and sublimity). ${ }^{12}$

This fatwa was in response to a circular distributed by the General Director of Health Ministry regarding the Prohibition of Medicalisation of Female Circumcission. According to the MUI, the letter indicates what in Arabic is called "tahrim alhalāl," disallowing the lawful. Human beings are not allowed to declare something harām which is actually haläl. Therefore, besides countering the circular from the Ministry of Health, this fatwa was also aimed at countering the arguments of feminist groups promoting the prohibition of circumcision on health grounds.

In the broader context, the increasing tendency of radicalism in Indonesia is affirmed by national surveys that show Indonesian Muslims are adhering more strictly to their religion over the last decade of the reform era. ${ }^{13}$ This represents a strong challenge to the long-established perception of the benign characteristic of Indonesian Islam mentioned above, which ultimately also influences perceptions of the status of women in Islam.

Based on this, I would like to provide some examples of the models of Islamic thought constructed by Indonesian Muslim scholars and clerics in understanding the position of women in Islam. Hamka $(1908-1981)^{14}$, Munawar Khalil (1908-1981) ${ }^{15}$ Jusuf Wibisono (1909-1982) ${ }^{16}$ and others are examples of early Indonesian Muslim scholars who sought to offer Islamic arguments to protect the position of women

9 Takariawan 2011; Nurmila 2009.

$10 \mathrm{http} / /$ nasional.inilah.com/read/detail/1336592/poligami-buku-bahagiakan-diri-dengan-satuistri\#.U5qjGBZm3dk, viewed on 13 June 2014.

11 Fatwā Majelis Ulama Indonesis No. 9A/2008 in MUI 2011: 236.

12 Ibid.

13 Burhanudin and van Dijk 2013: 7.

14 Hamka's complete name Abdul Malik Karim Amrullah. He is renown as a Muslim reformist from Muhammadiyah.

15 Munawar Chalil is a respected scholar of Muhammadiyah and wrote many books on the Qur'an, the history of Islam, women in Islam and other Islamic topics.

16 Jusuf Wibisono was a Muslim politician and member of Jong Islamieten Bond (JIB) who wrote Monogami atau poligami: masalah sepanjang masa. Jakarta: Bulan Bintang 1980. 
from the proliferation of Western liberation discourses that swept across Indonesia during their era. Their works mostly argue for the supremacy of Islamic teachings over Judeo-Christian notions in particular and Western traditions including women's rights in general. All Islamic teachings on women are, in their perception, intended to value and respect the dignity of women (martabat perempuan). Many Indonesian intellectuals such as Jusuf Wibisono, for instance, argued that polygyny is prescribed in Islam in order to prevent Muslim society from falling into the danger of extramarital sexual relations. ${ }^{17}$ By allowing or permitting a husband to have a second, third, and fourth wife, Muslim males have contributed to establishing an Islamic civilization by commanding the right and forbidding the wrong. In short, the era of these Muslim scholars can be regarded as the early establishment of "post-colonial Islamic patriarchy" in Indonesia.

In the 1980 s to the 1990 s, the discourse on women's rights in Indonesia was enlightened by Muslim thinkers who had both national and international traditions as the basis of their knowledge and experience. This group is often referred to as the Neo-Modernist Movement because most of them have a strong basis in the studies of both Islamic tradition (classical Islamic literature) and Western scholarly tradition. Usually, their education starts from traditional or modern Islamic boarding schools - studying the exegesis of the Qur'an, sunna, fiqh, Islamic legal theory and many others - before moving on to university degrees in Western countries and in the Middle East. Nurcholish Madjid (1939-2005) ${ }^{18}$, Abdurrahman Wahid (19402009) ${ }^{19}$ and Jalaluddin Rahmat ${ }^{20}$ are some of the key figures in this movement.

Their model of Islamic thought is characterized by creative efforts in negotiating and amalgamating the spirit of high Islam with localities on one hand and new developments facing the life of Indonesian Muslim communities - low Islam - on the other. ${ }^{21}$ They strongly rely on classical Islamic texts as the foundation of their thinking, and a robust acceptance of modernity as their orientation in actualizing religion for the future.

In the $1990 \mathrm{~s}$, Abdurrahman Wahid paved the way for a new discourse of Indonesian figh which was generally outlined in his tenet of pribumisasi Islam (indigenization of Islam). ${ }^{22}$ This concept emphasized the need to embed Islam within Indone-

17 Steenbrink 2006: 137.

18 Nurcholish Madjid was a Muslim scholar who promotes the importance for Indonesian Muslims to adopt the tradition of secularism, dividing the domain of mundane life and the domain of sacred life. Madjid established the University of Paramadina located in Jakarta.

19 Abdurrahman Wahid was the General Chairman of Nahdlatul Ulama, 1984-1999, and President of Indonesia, 1999-2001. Wahid is renowned for his contribution to the indigenization of Islam in Indonesia.

20 Jalaluddin Rahmat is renowned as a Muslim scholar who inclines towards Shia. In the 1990s, Rahmat is recognized for his idea on the actualization of Islam in the modern times of Indonesia.

21 Gellner 1983; Lessnoff 2007.

22 Wahid 1986. 
sia's local characteristics. ${ }^{23}$ The leitmotif of this discourse was twofold: the increased ability of this religion in adopting local values on the one hand and the strong grip on the tradition of Islam on the other hand. In this way, they apply the concept of mașlaha (public interest) in contextualizing Islam within the existing civilization. ${ }^{24}$ Within this framework, the crucial issues of Indonesia including gender issues are expected to be solved. Viewed from the perspective of post-modernism, Wahid's pribumisasi Islam can be understood as arguing that in order to become inclusive, Islam should be based on local characteristics and the diversity of justice and truth. ${ }^{25}$ The pribumisasi Islam should be formulated in order to invent a multifaceted Indonesian Islam. Once successfully formulated, the way forward towards reformism of religious thought - new interpretation - becomes predictable and effective.

Another effort to go the path of Islamic reformism has been signaled, for instance, by Munawir Sjadzali (d. 2004) who introduced the "reactualisation of Islam" (reaktualisasi Islam). Sjadzali was Minister of Religious Affairs, 1983-1993, and had a solid background in the field of Islamic studies as well as political sciences. What he means by this concept is to give attention to the needs of the Muslim community for reform of Islamic thought, using women rights in inheritance as a starting point. With regard to this case, Sjadzali suggests Islam has to be re-actualized, especially regarding the allocation of inheritance, which traditionally has women receiving only half of the inheritance of men. The reactualisation of Islam here is the reactualisation of figh, not of Islam itself, because Islam as religion is immutable and unchangeable, but figh as a result of interpretation of Islam is mutable and changeable. This is generally what Muslim scholars understand about Islam. The idea of the reactualization of Islam was also underpinned by the situation in which many women are the main source of income for families but do not hold a strong social and cultural position within the family. As breadwinners, women share and contribute to the family income, but the rights of execution in the affairs of household do not belong to women, but rather to men as husbands and heads of family, even though the husband may be unemployed. Based on this reality, Sjadzali suggests the "reinterpretation of inheritance-sharing formula" for men and women, which the Qur'an textually states as being two for man and one for woman, to become equal. In the modern context, wherein the division of labor and family responsibility is not strictly separated and divided, the 2:1 formula is no longer justifiable. The formula has to be reinterpreted in the lights of current social justice. In doing so, the $2: 1$ formula is understood as the application of sharia (Arabic: tațíq al-shari 'a), not the utmost objective of sharia which is justice. As the form of sharia application, the formula 2:1 is mutable, whereas the heart of sharia, the value of justice is absolute and unchangeable. Both Wahid's pribumisasi Islam as well as Sjadzali's reaktuali-

23 Wahid 1989.

24 Mujiburrahman 1999: 342.

25 Murray 1995: 2. 
sasi Islam are examples of efforts to bring the maqāsid concept down to earth to the local nature of Indonesia.

The reactualisation of Islam is more understandable when it is viewed from a specific notion in Islamic discourse that differentiates religious knowledge from religion. ${ }^{26}$ From this perspective, the formula $2: 1$ can be understood as the invention of figh, or science of religion, while what religion seeks is justice for humankind.

Apart from individuals, institutional efforts to create an Indonesian fiqh have also been initiated by the Ministry of Religious Affairs and the MUI. Both drafted and proposed the Kompilasi Hukum Islam (KHI, Compilation of Islamic Law) to the government of Indonesia during the Suharto era. According to the Ministry of Religious Affairs and MUI, the KHI is the result of collective ijtihād of Indonesian 'ulama $\vec{a}$ ' in formulating a fiqh that accommodates and includes the numerous local characteristics of Indonesia. They therefore claim that the KHI is Indonesian fiqh. One of Indonesia's characteristics transferred into the KHI is the provision on harta gono gini (an equal sharing of properties for men and women). Gono gini means fifty-fifty division for men and women with regard to inheritance. ${ }^{27}$ However, if we look at the content of the KHI as a whole, we can sense that traditional fiqh, which has patriarchal biases, remains prominent. As alluded to above, these efforts so far have been ineffective in solving injustices and unfairness affecting women. This is because all ideas promoted by neo-modernist Muslim scholars remain unable to provide a conclusive solution regarding the contradiction that exists between the religious texts and social reality.

\section{Fiqh al-'abawì}

Generally speaking, Indonesian Muslims place more emphasis on fiqh in their daily life than on other disciplines of Islam. This can be seen, for instance, from how they institutionalize the issues of figh in the form of fatwa bodies within their respective Islamic organizations, such as Nahdlatul Ulama (NU: Awakening of Ulama) with its Bahsul Masa' $i l^{28}$ (fatwa commission), Muhammadiyyah (Followers of Muhammad) with its Lembaga Tarjih (fatwa institution of Muhammadiyah), and Persatun Islam (Persis: Union of Islam) with its Dewan Hisbah (fatwa institution of Persis). Although these fatwa bodies can also respond to questions outside fiqh, the fatwa requests from their communities are generally related to issues of fiqh. As a conse-

26 Soroush 2002: 32

27 Lev 1972: 180.

28 Bahsul Masa'il (Indonesian way of saying bahth al-masā 'il) is the official forum of Nahdlatul Ulama to discuss and decide on fatwa. This forum operates from the level of the central board of NU to the level of district and sub-district chapters of NU. Interestingly, the bahsul masa' $i l$ within NU is not only held by the organization (jam iyya), but also by the community of NU $\left(j^{\prime a m a} a\right)$, therefore we can see this forum is practiced in various pesantrens of NU in whole Indonesia. 
quence, these organizations answer questions using the method of fiqh (al-istinbāt al-fiqhiyya). The Bahsul Masa'il is an obvious example of how the consideration of figh is widely used in Indonesia. Similar to NU, the Lembaga Tarjih of $\mathrm{Mu}-$ hammadiyah also considers the importance of fiqh. However, in 1997, for instance, $\mathrm{NU}$, through its National Congress (Munas) in Lombok, issued a fatwa about the legality of women becoming a vice-president of Indonesia. This fatwa was quite influential in paving the way for the Nahdlatul Ulama community to accommodate gender issues in their social and religious activities.

With regard to the current reality, the religious devotion of Indonesian Muslims is highly inferred by the notion of fiqh and my concern here is to link up this phenomenon with the patriarchal practice of Indonesian Muslims in their daily life. Such practices can be seen in daily attitudes and behavior where certain Islamic injunctions on women are used to justify the subjugation of women in Islam. For instance, the discourse of fiqh that states that the status of woman is half than that of man is generally used to cover the totality of women's position in Islam.

In this paper, I suggest that fiqh al-'abawi (patriarchal fiqh) is actually like other fiqh, but there are clear patriarchal tendencies within its discourse. Patriarchal fiqh can simply be seen as a discourse of Islamic jurisprudence that does not support equality and justice between men and women and also discriminates and subordinates women's rights to the interests of men. There are many examples of this, such as the ruling on man's leadership (imāma) both in the domestic and public space al-imāma al-șughrā wa al-imāma al-uzmā, domestic leadership and public leadership. The Qur'anic injunction used by Indonesian Muslim jurists is usually al-Nisầ': 34 saying:

"Men are in charge of women by [right of] what Allah has given one over the other and what they spend [for maintenance] from their wealth. So righteous women are devoutly obedient, guarding in [the husband's] absence what Allah would have them guard. But those [wives] from whom you fear arrogance - [first] advise them; [then if they persist], forsake them in bed; and [finally], strike them. But if they obey you [once more], seek no means against them. Indeed, Allah is ever Exalted and Grand."

The leadership of men in this verse is actually open to interpretation. But they usually underline this verse as an Islamic legal foundation to prevent women from leading prayers (imām al-șalāt) in the public sphere. This is one of many examples where an interpretation of a specific verse of the Qur'an is addressed to one gender.

However, I should say here that awareness about patriarchy in the discourse of Islamic jurisprudence is a relatively new phenomenon among Muslim legal jurists and people in Indonesia, only really coming in to the public consciousness in the 2000 s.

Generally, Muslim jurists think of fiqh as a neutral discipline, not favoring either men or women. This predisposition accords with historical narratives developed by the scholars of this discipline that the establishment of fiqh was, initially, stipulated 
by the need of Muslim-human beings to understand the will of God (tafaqqu fi al$d_{i n}$ ). Therefore, the creation of figh was originally absent from the interest of marginalizing and subordinating women. However, patriarchal affinities can occur in specific circumstances, including when books of fiqh were written down by their authors. The fiqh of the Islamic middle ages was the conceptualization of a maledominated religious discipline. There is no information regarding the presence of female authors of fiqh, or even the term faqiha (female Muslim jurist), a feminine of faqih (Muslim jurist). Viewed from the perspective of Michel Foucault, the genealogy of fiqh as a knowledge discipline should be critically investigated in order to discern the subjectivity of their authors. ${ }^{29}$

Modern social sciences have stimulated the emergence of self-discourse criticism among Muslim scholars including in re-assessing the development of fiqh in positioning women. Illuminated by this perspective, Qāsim Amīn (d. 1908), for instance, sees a direct relationship between the interpretation of Islam and the backwardness of women. Qāsim Amīn was arguably the most vocal Muslim intellectual in the struggle for the empowerment of women's rights in all aspects of life. ${ }^{30}$ Qāsim Amīn elaborated his thoughts and ideas in his two seminal books, Tahrīr al-Mar'a and Mar'a Jadìda.

The cultural encounter between Islam and modernity has made the new generation of Muslim scholars conscious that, as a monotheistic religion, Islam, which claims to be a religion of both justice and equality, should be implemented not only at the rhetorical but also at the practical level. Islam has to be a totality of theory and practice or discourse and praxis. It is not enough to rhetorically say that Islam brings justice, but it should be practically implemented in daily life. So this religion rejects slavery and the subordination of women to men. Women are human beings, just like men; men are human beings, just like women (al-nisā' shaqā'iq al-rijäl). Muhammad 'Abduh (d. 1905) and Rashīd Rị̣ā (d. 1935) have propagated the justice of Islam through al-Manār. Both introduced a new interpretation of some important verses of the Qur'an related to rights and the position of women in Islam and these served as their answer to the challenge of modernity. The most outstanding progressive interpretation of the Qur'an carried out by 'Abduh is that regarding the verse of al-Nisā', 1:

"O mankind, fear your Lord, who created you from one soul and created from it its mate and dispersed from both of them many men and women. And fear Allah, through whom you ask one another, and the wombs. Indeed Allah is ever, over you, an Observer."

29 Foucault 2012.

30 See 'Imāra 1989. This is a very complete account on the thought of Qasim Amin. See also http://www.aljadid.com/content/century-after-qasim-amin-fictive-kinship-and-historical-usestahrir-al-mara. 
This verse explains the creation (genesis) of human beings. 'Abduh states that this verse implies that the creation of human beings did not begin from Adam. The content of the term nafs wähida is not Adam, but a single source. Most importantly, 'Abduh argued that nafs wāhida, which has been understood by prominent 'ulama' in the past as Adam, is an influence from within isrä 'iliyyāt (Judeo-Christian) tradition, not from within the Islamic tradition. Muhammad 'Abduh is also very clear in reexamining the literal pronouncement of the Qur'an regarding polygamous marriage by revealing that the Qur'an intends monogamy, not polygamy as the Islamic marriage system. ${ }^{31}$

As previously stated, although the establishment of fiqh is not intended to construct patriarchy within fiqh, this tendency is apparent in the vast array of Islamic jurisprudence texts. There are several reasons why fiqh has a patriarchal tendency. First, fiqh is a discipline of Islamic knowledge derived (istinbāt) from the Qur'an and sunna in which the language is Arabic whose patriarchal lexicography is part of this language. The understanding and interpretation of al-Nisā' : 34, al-rijālu qawwamūna 'ala al-nis $\bar{a}$ '..., 'men are leaders of women...' introduced by traditional fuqah $\vec{a}$, lucidly indicates how the dimension of fatherness is strongly rooted within the texts. The majority of jurists interpret and use this verse as justification (dalil) that women cannot lead the prayer for men, although this verse has nothing to do with men's leadership in prayer. With reference to this verse, some fiqh books disallow women to become the imām for male congregants in șalāt al-jamáa 'a (communal prayer). However, Abduh's interpretation as mentioned above is not popularly used by traditionalist Muslim scholars in Indonesia. Still, the rib story of Adam is better-known among Indonesian Muslims.

With regard to the given example, it seems that Indonesian 'ulama $\vec{a}$ ' of fiqh in general did not consider the case of Umm Waraqa bint Nawfal (a famous female companion of the Prophet Muhammad), who led a prayer (imām) while some adult men were her followers (ma'mūm). It seems that Indonesian Islamic jurists just adhere to a saying of the Prophet Muhammad, "là ta'umanna rajulun 'imra'atan" (men do not really follow women in a prayer). ${ }^{32}$ Another example is that regarding nushüz (Arabic, meaning a wife's disobedience towards her husband). The ulama of fiqh act on the assumption that nush $\bar{z}$ is specific for women, while in fact the Qur'an mentions that men can also be judged as nushüz. Although al-Nisā': 128 speaks about the possibility of men being disobedient to their wives, but many books of fiqh dismiss this possibility. Ibn Rushd's Bidāya al-Mujtahid is often claimed as the prototype of modern fiqh, but it does not pay attention to any discourse on men's $n u s h \bar{u} z$. So perhaps the tradition surrounding the process of writing this book favored the supremacy of men. We can find many other examples of the patriarchal tendencies of figh which go against the principle content of both the Qur'an and sunna; namely justice and equality. These two examples illustrate that contemporary

31 Esposito 1994: 52; Saeed 2005: 183-4.

32 Hadzami: 453; Ghazzi 2009 
fuqāh $\bar{a}$ "s way of understanding such cases mostly relies on previous generations of fuq $\bar{a} h \bar{a}$, despite the fact that there have been many changes since those previous generations of $f u q \bar{a} h \bar{a}$ ' lived. Literal interpretations of Islamic religious texts reign supreme, even when they stand opposite to public interest (mașlaha). This is a general discourse of Islam related to women's issues.

Further, the founders of fiqh are mostly male. It is evident that male subjectivity has an influential role in the process of creating fiqh narratives. For instance, many previously mentioned maqāla (statements) of Islamic jurisprudence serve as evidence of this. To date, female scholars of fiqh are recognized, but their roles and thoughts are not extensively elaborated upon in works of figh. This remains the case, despite the fact that some prominent 'ulamā' of fiqh in the past, such as al-Shäfi ' $\overline{1}$ and Ibn Hajar al-'Asqalānī, recognized the teaching and guidance of their female teachers. In addition, they learned and studied Islam from these female teachers, but they did not acknowledge their role. If we go back to the first generation of Islam, ' $\bar{A}$ 'isha was the teacher of many of the Prophet's companions, but her capabilities as a female 'ulam $\bar{a}$ ' are not expounded as prominently as male companions of the Prophet. In addition, many of ' $\bar{A}$ 'isha's narrations of the sayings of the Prophet Muhammad are considered doubtful by Abū Hurayra. Abū Hurayra, as pointed out by Fatima Mernissi, was one of the contenders to the position of women which are abundant in the sayings of the Prophet Muhammad narrated by ' $\overline{\mathrm{A}}$ ' isha. ${ }^{33}$

Although patriarchal trends are not solely the domain of male 'ulamá', it is nonetheless very much evident in the content of their fiqh books. Sayyid 'Abd alRaḥmān b. Muḥammad, in Bughya al-Mustarshidīn, for instance, uttered "wa man jalasa ma 'a al-nisā' zâda allāh al-jahla wa al-shahwa", "anyone who sits down together with women, God will give him/her more stupidity and uncontrolled desire." ${ }^{34}$ This avowal is indicative of the unambiguous patriarchal content in figh and very much against the unbiased principle of the Qur'an and sunna that grants men and women equal rights and positions as human beings. Another opinion declares that women are not given the duty of, and are even prohibited from, seeking knowledge other than specific knowledge related to "religious obligations" (alwäjihāt) such as knowledge on five daily prayers (șalāt), pilgrimage (hajj) and fasting (saum). This is also not in compliance with the Qur'an and sunna. The Qur'an and sunna endorse women as being similar to men in their freedom to seek knowledge. The Prophet Muhammad said that "talab al- 'ilm farị̣̂ 'alà kulli muslimīn wa muslimātin, seeking knowledge is a duty for Muslim men and women." We can find many other examples of patriarchal affinities within works on Islamic jurisprudence which are widely circulated and read in Indonesia ${ }^{35}$.

33 Mernissi 1987: 56.

34 This is quoted by Sayyid Abdurrahman from Bujayrimī 'alā al-'Iqnä', one of most highlyconsidered fiqh books among 'ulamä' in Indonesia. The Bughya al-Mustarshidīn has become a famous reference for pesantren 'ulamā' and students in Indonesia (Husayn b. 'Umar, n.d.).

35 Manshur: 45. 
The patriarchal predisposition of figh can be seen in the model of transmission and dissemination of this discipline, both of which are controlled by male 'ulamá'. In Indonesia, pesantrens, centers of Islamic learning, and Islamic forums, which serve as venues for the formulation and spread of Islamic discourse remain the domain of male 'ulamá'. Leaders, teachers and preachers are mostly males. In the coeducational pesantren or Islamic study groups, male teachers can lecture both male and female students, but the same cannot be said for female teachers. Male teachers can work in learning centers dominated by female students, but women rarely teach in male-dominated forums, unless certain conditions are fulfilled such as they have specific expertise which are not found among their male colleagues or their presence must be concealed with a dividing cover (hijāb or sātir). They are also given the opportunity to teach during darüra (religious emergency). This tendency becomes stronger in Indonesia now especially among the students and activists of Salafi groups. Islamic learning circles managed by PKS (Partai Keadilan Sejahtera, Prosperous Justice Party), for instance, implement this model at many state universities. In their perspective, segregation between males and females in teaching and learning processes are not only part of morality, but fulfills religious demands in seeking knowledge.

In Indonesia's electronic media, the presence of female preachers in the last decade has been a quite impressive phenomenon. On the one hand, it suggests a growing involvement of women in the public sphere, but on the other hand, their presence seems to extend Islamic patriarchy. Indonesian TV stations broadcast preaching programs hosted by female muballigha (preachers), including Lutfiah Sungkar (female preacher from Jakarta), Neno Warisman (former pop singer), Mamah Dedeh, Teh Ninih (Abdullah Gymnastiar's wife) and many others. These figures are female preachers who preach for women, but their perspectives in understanding the issues of women remain grounded in the perspective of men. The content of their preaching is similar to that of male preachers, which promote the interpretation of male jurists. When Mamah Dedeh was asked by an audience member about the legal status of pregnant women, and whether they can get married or not during her pregnancy, Mamah Dedeh answered by quoting two opinions among Islamic jurists; first it is allowed and second it is not allowed. For the first fatwa, Islam does not recognise extra marital intercourse therefore the status of the child resulting from such a relationship is illegal. Another example was when Mamah Dedeh was asked about the legal validity of interfaith marriages. Dedeh answered that this marriage is not allowed. She seems to be very sure about her answer, although interfaith marriages remain a highly contested issue in Islamic legal jurisprudence. Dedeh does not try to go throughout the various opinions of this discourse. ${ }^{36}$ The two examples reflect the

36 This talkshow was broadcasted by Indonesian TV station on 31 March 2011. It can be see at https://www.youtube.com/watch?v=JSD6oQfEHpE\&list=PL0DACC36F8C958D10, viewed on 2 May 2013. 
strong influence of male 'ulama', although Islamic jurists remain divided on the latter case.

All the circumstances discussed above represent the dissemination of Islamic knowledge that further contributes to the consolidation of more patriarchal tendencies within fiqh. ${ }^{37}$

The socio-political and cultural structures of society in the past when the figh was created were also very male-dominated. As an Islamic science, the development of fiqh began in the Arab peninsula from the third generation after the death of the Prophet Muhammad. The socio-political and cultural structures of society in the region at that time and afterwards in general favored men. This also contributed to the establishment of patriarchal tendencies within fiqh, as it is very difficult to detach Indonesian 'ulama's's understanding of fiqh from Arab customs. This is understandable because most of the early fiqh discourse was constructed within the milieu of Arab culture. Many Indonesian 'ulama $\bar{a}$ ' consider the mixing of Islam and Arab culture in fiqh as the totality of Islam including women's issues. For instance, all marriage-related issues, such as the leadership of men in the household, seem to be interpreted as part of the religious discourse. However, when we read al-Nisā' : 34 , the Qur'an outlines social and cultural issues regarding male leadership when they fulfills two capacities: cultural and political leadership ability as well as the ability to provide for his family. If he does not have these two capacities, then leadership can shift to others who have these capacities.

With regard to this issue, Indonesian male and female Muslim scholars and activists such as Husein Muhammad (b. 1953), Nasarudin Umar (b. 1959), Mahasin, Badriyah Fayumi, Maria Ulfa, Ruhaini Dzuhayatin, Hamim Ilyas and many others have tried to offer a reinterpretation of gender issues, but their works are generally not recognized by most Indonesian Muslims. In addition, those who think of new ideas and reinterpretations of relations between men and women by utilizing gender frameworks are often stigmatized as devotees of liberal and Western ideology. Stigmatization like this becomes a real challenge in eradicating patriarchy in Indonesia. As a consequence eradicating fiqh al- 'abawi and proposing fiqh al-nis $\bar{a}^{\prime}$ is not only a scientific endeavor, but also an ideological endeavor to shape a gender biasfree Islamic discipline.

\section{Maqāșid and its use for gender equality}

Literally speaking, fiqh means fahm ghard al-mutakallim, understanding the objectives of God. The mutakallim here is God, the Speaker. In Islamic legal theory, any attempt to understand the intention of God is called 'ilm al-maqāsid (science of God's goals). For those who are familiar with the study of fiqh and ușul al-fiqh, although it is rarely used in the Indonesian context, maqāssid has been extensively

37 Hasyim 2001: 133. 
discussed among Indonesian Muslim scholars over the last two decades. Maqāsid literally means objectives, intentions, and goals. The scholars of fiqh and $u s \underline{u} l$ al-fiqh define that the creation of sharia (God's law) is to enforce al-mașlaha (beneficence) and to avoid al-mafäsid (harms) by providing protection for the five essential needs of human beings; al-dīn (religion), al-hayāt (life), al- 'aql (reason), al-māl (property) and al-nasl (generations). Yūsuf Qaradāwī adds one more objective: hifz al- irọ (protection of human dignity). This kind of definition is clearly evident in a statement made by al-Ghazālī, "lakinnanā na 'nī bi al-mașlaha al-muhāfaza 'alā maqșūd al-shāri' wa maqșūd al-sharī‘ khamsa wa huwa 'an yuhfiza 'alayhim dīnuhum, wa nafsuhum, wa aqluhum, wa nasluhum, wa māluhum, fakullun mā yatadammanu hifẓa hādhihi al-ușūl al-khamsa, fahuwa mașlaha, wa kullu mā yafütu hădhihi alusül fahuwa mafsada wa daf'uhā maslaha" [what we mean by goodness here is to protect the original objective of the Law Maker, and that the objectives of the Law Makers are five, that: is to protect the religion (belief) of human beings, the life of human beings, human reason, the future generations of human beings, and the property of human beings. Everything that maintains the protection of these five foundations is categorized as mașlaha, and everything that rejects the protection of the five foundations is categorised as evil; to avoid the evil is goodness $]^{38}$. In the discourse of Islamic legal theory, the protection of five basic needs of human beings is called al-darūriyyāt al-khamsa (the five necessities) or maqāșid al-sharī 'a. ${ }^{39}$

Historically speaking, the early development of the maqāsid concept can be traced through, for instance, al-Juwaynī (478 AH). He was the first 'âlim to emphasize the importance of understanding this notion behind the establishment of sharia. ${ }^{40} \mathrm{Al}$-Ghazāli $(505 \mathrm{AH})$ developed a more complete concept of maqāsid as the foundation of creating mașlaha (public interest) and avoiding mafsada (badness, uselessness). After al-Ghazālī, the maqāșid concept was further developed by others, such as Faḥr al-Dīn al-Rāzi (606 AH), Sayf al-Dīn al-'Āmidī (631 AH), al-'Izz b. 'Abd al-Salām (660 AH), Shihāb al-Dīn al-Qarāfî (685 AH), Najm al-Dīn al-Ṭūfì (716 AH), Ibn Taymiyya (728 AH), Ibn Qayyim al-Jawziyya $(751 \mathrm{H})$, and Abū Ishāâq al-Shāțibī (790 AH). Among theoreticians of the maqāṣid concept, al-Shātịibi is cited as among the greatest innovators in the discipline of usūl al-fiqh through his masterpiece Al-muwaqāt fì ușūl al-sharī'a. Ali Shāmi' al-Nishār describes alShātibī's work as the most systematic and complete book of Islamic legal theory. ${ }^{41}$ Many Indonesian 'ulam $\bar{a}$ ' accept the importance of al-Shātibī as a legal foundation for developing new interpretations of Islamic teachings.

Many Indonesian Muslim jurists have employed the concept of maqāșid for different issues and interests. Progressive Muslim groups use the concept as a primary analytical tool to discover solutions for the modern problems faced by Indonesian

38 See al-Ghazālī in book al-Mustashfa, Vol. I.: 286.

39 F. Opwis 2005; F. M. M. Opwis 2010.

$40 \mathrm{~F}$. Opwis 2005.

41 Al-Nishār 1978: 82. 
Muslims. ${ }^{42}$ This group regards mașlaha as the important concept in classical Islamic theory because of the idea promoted by this notion that God has intentions behind the creation of sharia. Within this theory, it can be said that sharia is not only what is textually stated in the source of sharia (nas zähir), namely the Qur'an and sunna. Religious texts are a means for God to reveal His message and goals, but they have limitations - space and time - and the intention of God has not. From this point, therefore, progressive Muslims try to think of Islam as not only being based on texts, but primarily upon context. Indonesian progressive Muslims favour this approach because it creates space for open reasoning and also protecting religion from manipulation at the hands of its interpreters and users. ${ }^{43}$

However, progressive Muslim groups are not alone in using this theory. Those who are wrestling with the formal application of sharia in Indonesia, such as MUI, also employ maqāșid but in a different sense. MUI's objective in using maqāșid is to protect the application of this concept from being misunderstood and misused by the progressive Muslim groups. In this regard, MUI in 2005 introduced a specific fatwa on the definition of public interest. This fatwa was issued in order to counter liberal streams of thinking promoted by Muslim intellectuals and activists such as Ulil Abshar Abdalla, Lutfi Assyaukani. Among these so-called liberal groups are those who adopt gender perspectives in their approach to Islamic teachings. MUI's criticism related to the misuse of maqāsid can be seen in the organization's fatwa on maslaha. In this fatwa, MUI argued that the concept of public interest is often employed by such groups to determine an Islamic legal opinion without following the

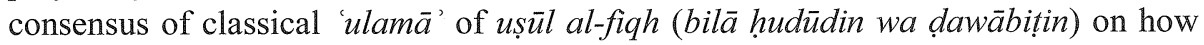
to properly apply this concept. MUI also states that the misuse of this tenet by some groups has led to mistakes in the formulation of fatwas and to confusion in the Muslim community. MUI felt obliged to set out the proper use of Islamic law by issuing a set of criteria for mașlaha. The general content of this fatwa is concerned with three points. First, the tenet of mașlaha in the perspective of Islamic law is to implement the aims of purposive sharia (maqāșid al-sharì $a$ ) that implies a full protection of al-darüriyyāt al-khamsa (the five necessities) as mentioned above. Second, MUI argues that the notion of public interest must be applied in accordance with the main textual sources of Islam (the Qur'an and sunna). The use of this concept in a way which contradicts the Qur'an and sunna cannot be justified as mașlaha. Third, a body that has the authority to rule on the criteria of public interest is an institution that has competency in this field, namely the ' $u l a m \bar{a}$ '.

Why does contestation occur between so-called progressive and retrogressive groups of Indonesian Muslim scholars and activists using the concept of maslaha? The contestation takes place because the theory of maqāsid itself offers the possibility of producing a new interpretation of Islam. Here, sharia is no longer read and interpreted in the light of textual and inter-textual boundaries of meaning, but also in

42 Rachman \& Shofan 2010: 133-4.

43 Ibid. 
social, cultural and political realms. Here, the maqāșid differs from other methodologies of Islamic legal theory such as qiyās that can only accommodate the judgments of textual and inter-textual interpretations.

However, the use of maqāșid as a methodology of ijtihād (istinbāt al-hukm) is not common in the Indonesian context. Muslim scholars of Islamic legal theory and jurisprudence tend to refute the use of maqāsid because this concept is not part of the main works of the four schools of Islamic law. The maqāssid is relatively new compared to the other foundations of istinbāt such as $i j m \bar{a}^{\prime}$ (collective agreement) and qiyās (analogy). In Indonesian context, the use of maqāssid in the fatwa process became popular during the 1990s. Nahdlatul Ulama only discussed this issue in the Cipasung National Conference of 1994. This organization allowed the use of maqāsid as the method for producing a fatwa as long as it does not contradict the Qur'an and sunna. However, since this decision it has been rare for NU fatwas to use the concept of maqāșid in drawing up Islamic legal opinion.

\section{Toward fiqh al-nis $\bar{a}^{\prime}$}

As mentioned above, the use of maqāsid or mașlaha (purposive-fiqh) to solve the problems of rereading gender issues in Islam began with the emergence of Muslim feminists (Indonesian: feminis baru) in the 1990s. Husein Muhammad, Wardah Hafidz, Masdar F. Mas'udi, Lies Marcoes, Dawam Rahardjo, Muslim Abdurrahman and many others are examples of Muslim scholars who use the perspective of gender in fighting for women rights in Islam. ${ }^{44}$

This emerging group attempted to develop maqāșid as a methodological lens for identifying the compatibility between discourse and practice of human rights in Islam, and Islam and gender rights in particular. They argued that the essence of the five necessities of sharia or mașlaha is to establish the principles of justice and equality, which is very similar to the objectives of universal human rights. Those who use this concept believe that gender justice and equality in Islamic discourse and practice can be implemented through the use of maqāssid. In their view, the five necessities are a basic foundation that enables a dialogue process between the message of the sacred text and the social reality. For these feminists, the failure of previous attempts in resolving gender problems within fiqh is due to the use of incorrect methods for rereading Islam, including the use of the maqāssid theory.

However, it is worth noting that the concept of maqassid used and referred to by Indonesian Muslim scholars ist still influenced by al-Shāțibī. Al-Shāțibi's maqāṣid has been widely employed by both Muslim scholars and gender advocates, but has not yet effectively offered a solution to gender-related issues in Islam that need an approach which goes beyond al-Shāțibī's view on mașlaha. In addition, the concept

44 These persons organized a workshop on Islam and feminism by inviting Riffat Hasan in Bogor, West Java. 
of al-Shātịīì's maqāșid can be used to establish male-oriented interpretations of Islam due to its limitedness in providing a way out of delicate issues, such as the contradiction between text and context that has long served as a source of gender injustice and discrimination within Islamic legal theory and jurisprudence. Some elements which contribute to the continuation of patriarchy within Islamic texts cannot be resolved by using al-Shātibī's concept. In general, al-Shātibī's maqāșid have no clear understanding of how to proceed when Islamic texts apparently contradict public interest. It is true that al-Shâtibī constructs the theory of kulliyāt and juz'iyyāt - the former being related to the universal principles of Islam and the latter related to the particular principles of Islam - to solve some contradictions, but the supremacy of the text is still primary. ${ }^{45}$ Prioritizing the supremacy of texts makes finding solutions to contemporary issues difficult, because the texts do not provide clear guidance or otherwise remain silent on certain issues, while the context always develops in time and space.

So, the development of fiqh al-nis $\bar{a}^{\prime}$ needs a new conceptualization of maqāssid, which differs from Shâtibī's concept that prioritizes the supremacy of the text. The approach of Najm al-Dīn al-Tūîi (b. 1276/7 d. 1316) is highly recommended in this regard, specifically because he provides a concrete solution on how to avoid contradictions between text and context. Before discussing al-Tūfî's thought further, however, it is worth defining first what is meant by fiqh al-nis $\vec{a}$ ' within the context of this paper. This term gained notoriety since the International Conference on Population and Development (ICPD) held in Cairo in 1994 which discussed women's reproductive health (rights). Many Indonesian Muslim scholars and activists participated in this conference, including Masdar F. Mas'udi, Lies Marcoes, Husein Muhammad. In response to this international event, academia, civil society groups and women organizations in Indonesia conducted activities ranging from research to advocacy related to women's reproductive rights in particular and Islam in general. Indonesian Islamic organizations and NGOs tackled the issue of reproductive rights through programs on Islamic jurisprudence and in programs for the Muslim community in pesantren. P3M (Perhimpunan Pengembangan Pesantren dan Masyarakat, Indonesian Society for Society and Pesantren), the Women's Youth Wing of Nahdlatul Ulama, the Centre of Women's Studies at the State Islamic University Yogyakarta and many others worked together with male and female theologians to provide solid arguments in support of gender justice and equality.

Fiqh al-nis $\vec{a}^{\prime}$ is defined here as fiqh which is (1) focused on matters pertaining to women (fiqh fi al-nis $\bar{a}^{\prime}$ ), (2) from the perspective of women (fiqh min al-nisa '), and (3) for the dignity of women ( $i q h$ f $f \bar{i}$ al-nis $\bar{a}^{\prime}$ ). This definition is taken from the grammatical understanding of the term fiqh al-nis $\bar{a}^{\prime}$, the construction of which contains the meaning of $f i$, min and $l i$. Both Masdar F. Mas'udi and Husein Muhammad from Nahdlatul Ulama, the largest Muslim organization in Indonesia, take this approach. From this simple definition, fiqh al-nis $\vec{a}^{\prime}$ is then further broadened and de-

45 Opwis 2010. 
veloped into important topics regarding the position of women in fiqh. But the understanding of maqāșid or mașlaḥa used by Indonesian Muslim scholars remains strongly influenced by Shāțibī and mainstream scholars, who are not able to consistently solve crucial issues such as polygamy, women's leadership in the household and, of course, some issues regarding sexuality. The argument that kulliyāt must be prioritized over juz'iyyāt remains inadequate, because the former prioritizes textual evidence from the Qur'an or sunna. When mașlaha contradicts the textual evidence in these two foundational sources of Islam, the mașlaha should be rejected. This is what I was referring to by the term inter-textual approach, as mentioned above.

Al-Tüfî's approach is best placed to resolve the issues around the use of mașlaha for the conceptual improvement of fiqh al-nis $\bar{a}^{, 46}$ Al-Tūfì is well-known in Indonesia, but thorough studies and the application and use of his concept in the public sphere of Islamic debate are relatively rare. Al-Ṭūfí was a Muslim jurist from Ibn Hanbal's school of Islamic law ${ }^{47}$. Al-Ṭūfì's conception of mașlaha was compiled in a small treatise called al-risāla fi ri 'âya al-mașlaha. The main thrust of his thought is that maslaha should be prioritized when it contradicts the textual evidence in the Qur'an and sunna and the consensus of scholars. Al-Tūfì states that the nașs - the Qur'an and sunna - and the consensus of ulama - ijma $\bar{a}^{-}$- sit atop the hierarchy of the nineteen sources of Islam. ${ }^{48}$ These two foundational sources can either be in accordance or dissonance with mașlaha. When the mașlaha contradicts textual evidence from the Qur'an and sunna and also ijma $\bar{a}^{\prime}$, al-Țüfi states that the mașlaha should be selected in the first instance. The position of mașlaha can be regarded as takhșīs (emphasizing) or bayān (explaining) the nașș and ijmā' (in al-Ṭüfi's Arabic statement, wa 'in khālafahā wajaba taqdìm al-mașlaḥa 'alayhimā bi-țarīq al-takhșịs wa al-bayān lahumā... kamā taqaddama al-sunna 'alā al-Qur'ān bi-țarīq albayān). ${ }^{49}$ This approach can contribute to solving the longstanding problem of the contradictions between nașs and mașlaha.

When responding to an opinion that maslaha is not equal to consensus, because the former is based on the qat ${ }^{\prime} \bar{l}$ (cogent) textual evidence, while the latter is not, alȚüfi stated that "'inna ri âya al-mașlaha aqwā min al-ijmā", wa yalzamu min dhālika annahā min adilla al-shar 'i, li 'anna al-aqwā min al-aqwā aqwā,..." (surely the public interest is stronger than consensus therefore the strongest of the strongest is strongest). ${ }^{50}$

In more radical terms, al-Ṭūfi provides three arguments as to why mașlaha should be prioritized over the nașs and consensus. First, mașlaha is a place of

46 Opwis 1993.

47 More elaboration on the history of al-Țūfi, see http://referenceworks.brillonline.com/entries/ encyclopaedia-of-islam-2/al-tufi-COM_1244?s.num=53\&s.rows=100\&s.start=10, viewed on 10 June 2014.

48 Opwis 1993: 23.

49 Ibid.

50 Opwis 1993: 25. 
agreement and $i j m \bar{a}^{c}$ is a place of disagreement and upholding that which is agreed upon is better than upholding that which is disagreed. Second, there are various nușus (plural of nașs ) which contradict one another. They are the sources of dissenting opinions which are not accepted by sharia. Mașlaha is the source of agreement which is praised by sharia and therefore adhering to the public interest is the better option. Third, there are many cases in which the sunna is prioritized over the Qur'an, where the two contradict with one another.

With regard to the explanation above, al-Țüfís conception of mașlaha can be used as a principal interpretive foundation to construct fiqh al-nisă'. Al-Tūfì's prioritization of mașlaha is very helpful in resolving important gender-related issues in Islam such as polygamy, inheritance, leadership, violence against women and so forth. Polygamy for instance, can be declared prohibited by using the logic of alȚûfi, as mașlaha is prioritized above the textual evidence of the Qur'an.

Al-Țufi's place in the history of both classical and contemporary fiqh is little known, especially because his treatise on this matter is very brief and is not discussed in other works. It is common in classical fiqh and ușul al-fiqh that some works receive more attention and are elaborated on more extensively than other works. Sharh, literally meaning explanation, is performed when the work is tiny and mukhtasar is performed when the work is voluminous. Those who undertake both sharh and mukhtașar can be the same or different authors. Both sharh and mukhtașar are often composed by the students of the author. In the case of al-Tunfî's treatise, Rashīd Riḍa commented that al-Ṭūf̂̀'s al-risāla fì ri 'âyat al-mașlaha offers an understanding of the concept of mașlaha not found in other works. ${ }^{51}$

In the context of fiqh development in Indonesia, Munawir Sjadzali uses al-Tüfí's concept of maslaha for his work on the reactualisation of Islam. ${ }^{52}$ Using the supremacy of mașlaha over consensus ( $i j m \bar{a}{ }^{\prime}$ ) introduced by al-Tüfi, Sjadzali comes to the conclusion that inheritance can be divided equally between men and women in order to fulfill the objective of sharia (maqassid). Sjadzali refers to the objectives of sharia first introduced by al-Țüfi. Munawir's attempt can be seen as an example of how Indonesian Muslim scholars have tried to use al-Țūfîs ideas to solve the problems of Islamic law in Indonesia. However, Indonesian Muslim scholars since Sjadzali have not referred to the concept of the supremacy of mașlaha over consensus.

\section{Concluding remark}

The robust tendency of patriarchal fiqh in Indonesia has marginalized alternative discourses empowering the rights of women. Although Indonesian Muslims adhere to national laws, which recognize the equality of men and women, religion still has a significant influence on their daily lives. This is reflected in their appreciation of

51 Al-Tūfĩ 1993.

52 Nafis 1995. 
figh as one of most powerful elements of Islam that shapes the religiosity of Indonesian Muslims. Therefore, gender-based injustices and discrimination in the Muslim community are also often influenced by fiqh. As a result, the establishment of a new figh supportive of the rights of women - fiqh al-nis $\bar{a}^{\prime}-$ can help address these injustices. The concept of maqāșid or mașlaha introduced by Muslim legal theorists provides a potential starting point for the introduction of this figh.

As a concept, fiqh al-nisā' remains superficial and needs further elaboration and explanation in order to serve as the foundation of women's empowerment. So far, the challenge for Indonesian Muslim scholars is to formulate fiqh al-nis $\bar{a}^{\prime}$ at both the theoretical and practical levels. At the theoretical level, the prioritization of mașlaha, such as introduced by al-Ṭüfi, serves as a promising platform for the conceptualization of fiqh al-nis $\bar{a}$ '. But at the practical level, it remains difficult for most 'ulama' in Indonesia to accept this approach. Nevertheless, factual experiences of genderbased injustices and discrimination will serve as modalities for constructing a robust conceptualization of fiqh al-nis $\bar{a}^{2}$. This further supports the need of Indonesian Muslims to have their own fiqh - Indonesian fiqh.

\section{Bibliography}

Azra, Azyumardi (2013): Distinguishing Indonesian Islam: some lessons to learn, in: Jajat Burhanudin \& Kees van Dijk (eds.), Islam in Indonesia: contrasting images and interpretations. Amsterdam: Amsterdam University Press, 63-74.

Burhanudin, Jajat \& Kees van Dijk (2013): Introduction. in: Jajat Burhanudin \& Kees van Dijk (eds.), Islam in Indonesia: contrasting images and interpretations. Amsterdam: Amsterdam University Press.

Esposito, John L. (1994): Islam and politics. New York: Syracuse University Press.

Foucault, Michel (2012): The archaeology of knowledge. New York: Knopf Doubleday Publishing Group.

Gellner, Ernest (1983): Muslim society. Cambridge: Cambridge University Press.

Ghazzi, Luqman (2009): Srikandi perisai Nabi. Selangor: PTS Islamika.

Hadzami, KH. M. Syafi'i (1982): Taudhihul Adillah. Jakarta: Menara Kudus.

Hasyim, Syafiq (2001): Hal-hal yang tak terpikirkan tentang isu-isu keperempuanan dalam Islam. Bandung: Mizan.

Ḥusayn b. 'Umar, Abd. al-Raḥmān b. Muḥammad (n.d.): Bughya al-mustarshidīn fì talkhīs fatāwā ba'd al-a'imma min al- 'ulamā' al-muta'ākhirīn. Bandung: Syirkah Ma'arif.

'Imāra, Muhammad (1989): Qāsim Amīn, al-a māl al-kāmila, al-Qāhira: Dār al-Shurūq.

Kathirithamby-Wells, Jeyamalar (1976): Inderapura sultanate: the foundations of its rise and decline, from the sixteenth to the eighteenth centuries, in: Indonesia 21: 64-84.

Lessnoff, Michael (2007): Islam, modernity and science, in: Siniša Maleševič and Mark Haugaard (eds.), Ernest Gellner and contemporary social thought. Cambridge: Cambridge University Press.

Lev, Daniel S. (1972): Islamic courts in Indonesia: a study in the political bases of legal institutions. Berkeley: University of California Press.

Manshur, Abd al-Qadir (n.d.): Buku pintar fikih wanita. Jakarta: Penerbit Zaman. 
Mernissi, Fatima (1987): Beyond the veil: male-female dynamics in modern Muslim society. Indiana: Indiana University Press.

MUI (2011): Himpunan fatwa MUI sejak 1975. Jakarta: Erlangga.

Mujiburrahman (1999): Islam and politics in Indonesia: The political thought of Abdurrahman Wahid, in: Journal of Islam and Christian-Muslim Relations 10 (3), 339-52.

Murray, Mary (1995): The law of the father? Patriarchy in the transition from feudalism to capitalism. New York: Routledge.

Nafis, Wahyuni ed. (1995): Kontekstualisasi ajaran Islam: 70 Tahun Prof. Dr. H. Munawir Sjadzali, M.A. Jakarta: Ikatan Persaudaraan Haji Indonesia.

Nishār, 'Alī Shāmi' al- (1978): Manāhij al-baḥthi 'inda mufakkir al-islāmi iktishāfal-manhaj al- 'ìlm fì al-alām al-islāmī. Al-Qāhira: Dār al-Ma'ārif.

Nurmila, Nina (2009): Women, Islam and everyday life: renegotiating polygamy in Indonesia. New York: Routledge.

Opwis, F. (2005): Maslaha in contemporary Islamic legal theory, in: Islamic Law and Society. http://www.ingentaconnect.com/content/brill/ils/2005/00000012/00000002/art00002.

Opwis, Felicitas Meta Maria (2010): Mașlahah and the purpose of the law: Islamic discourse on legal change from the 4th/10th to 8th/14th century. Leiden \& Boston: Brill.

Rachman, Budhy Munawar \& Moh Shofan (2010): Argumen Islam untuk sekularisme. Jakarta: Grasindo.

Rawls, John (2011): Political liberalism: expanded edition. New York: Columbia University Press.

Riddell, Peter G. (2007): Aceh in the sixteenth and seventeenth centuries: 'Serambi Mekkah' and Identity, in: Anthony Reid (ed.), Verandah of Violence: The background to the Aceh problem. Singapore: NUS Press, 38-51.

Saeed, Abdullah (2005): Approaches to the Qur'an in contemporary Indonesia. Oxford: Oxford University Press.

Schech, Susanne \& Mochamad Mustafa (2010): The politics of gender mainstreaming poverty reduction: an Indonesian case study, in: Social Politics: International Studies in Gender, State and Society 17 (1), 111-35.

Soroush, Abdolkarim (2002): Reason, freedom, and democracy in Islam: essential writings of Abdolkarim Soroush. Oxford: Oxford University Press.

Steenbrink, Karel A. (2006): Dutch colonialism and Indonesian Islam: contacts and conflicts, 1596-1950. Amsterdam and New York: Rodopi.

Takariawan, Cahyadi (2011): Bahagiakan diri dengan satu istri. Solo: Era Adicitra Intermedia.

Taylor, Jean Stewart (1976): Raden Ajeng Kartini, in: Signs 1 (3), 639-61.

Ṭūfì, Najm al-Dīn al- (1993): Risāla fi ri 'āyat al-mașlaḥa. Al-Qāhira: Dār al-Mișriyya alLubnāniyya.

Wahid, Abdurrahman (1986): Islam Indonesia menatap masa depan, in: Abdul Mun'im Sholeh (ed.), Pribumisasi Islam. Jakarta: P3M, 81-96.

Wieringa, Saskia (2006): Islamization in Indonesia: women activists' discourses, in: Signs 32 (1), 1-8.

Weithman, Paul (2011): Why political liberalism?: On John Rawls's political turn. Oxford: Oxford University Press.

Wibisono, Jusuf (1980): Monogami atau poligami: masalah sepanjang masa. Jakarta: Bulan Bintang. 


\title{
Gender as a social regime in the Islamic context- a case study of the Muhammadiyah
}

\author{
Siti Ruhaini Dzuhayatin
}

This paper aims to examine the gender dimension in the official pronouncements of the Muhammadiyah, the second largest Islamic organization in Indonesia. Gender as a social regime is a relatively new field in gender studies outside it's hitherto focus on politics. Based on the works written by R. W. Connell who defines gender regime as gender order ${ }^{1}$ and by Biku Parekh who outlines a collective identity upheld by race, ethnicity, class and gender ${ }^{2}$, this paper explores how gender is constructed within the Muhammadiyah and how gender issues are contested in its official pronouncements. It begins with a brief description of Muhammadiyah's history since its inception in the colonial era, and continues to analyse its dynamic growth after Indonesia's independence and the latest challenges it faces in the aftermath of the collapse of Soeharto's regime in 1998. This account reflects how gender has become the "swinging pendulum" of Muhammadiyah's reorientation somehow towards conservatism.

\section{The Muhammadiyah: a brief historical background}

The Muhammadiyah is the second largest Modern Muslim organization in Indonesia with a membership claimed to be around 30 million people. ${ }^{3}$ The Nahdlatul 'Ulama (NU), the guardian of the Islamic tradition is the largest Muslim organization with a membership of around 40 or 50 million followers. ${ }^{4}$ The debate between the modernists and the traditionalists centres on the Islamic structures they employ within their organizations. The Nahdlatul Ulama which was established a decade after the Muhammadiyah by a group of kiai (traditional Islamic scholars) aimed at preserving the Islamic classical framework as developed by the four Sunni schools. Their inclusive

1 Connell 1987.

2 Parekh 2008.

3 Interview with prominent central board leaders such as Haidah Nashir, Rosyad Sholeh, Yunahar Ilyas from January - March 2011 in Yogyakarta.

4 No exact information on membership can be obtained for both organizations. This is only an estimated member pronounced by the elites such as Abdurrahman Wahid who roughly estimated the adherents od NU as twice as those of Muhammadiyah. 
framework is reflected in their adoption of older local practices which harmoniously amalgamated with Hindu elements handed down for generations. This tradition evolved around the so-called pesantren (boarding schools), the Hindu preservedschool system adopted by the nine prominent Islamic scholars believed to have spread Islam into the Archipelago in the early $9^{\text {th }}$ Century. The owner and head of a pesantren is a kiai, the respected teacher where many santri (students) come to for to acquire Islamic knowledge. The pesantren and the kiai are like a fountain where santris gain the flow of knowledge that will last for their entire lives. For the santri, a kiai is not merely a teacher but he is able to discharge blessing because of their pious and distinctive spiritual capacity which is considered higher than that of ordinary people. A kiai is a thus a charismatic leader where people seek religious, social and even political guidance. ${ }^{5}$

Muhammadiyah which literally means "followers of Muhammad" (the Prophet of Islam) is one of the modern Islamic organizations that emerged in the early twentieth century following the introduction of the Ethical Policies that were adopted by the Dutch colonial administration which allowed the indigenous people to enjoy modern education. Although intended pragmatically to produce local clerics, mass education unintendedly raised nationalism among indigenous intellectuals. As Jayawardena has highlighted, the nationalist movements at the turn of the twentieth century in the Third World like in India, Sri Lanka, Malaysia and Indonesia had two objectives: exorcising colonial power and gaining a modern identity through dismantling the pre-colonial structures of the ruling dynasties as well as the religious orthodoxies. Modern education produced significant modalities and ideological bases for social reform which were materialized in the proliferation of political and social organizations, with secular as well as religious outlooks. The secular or socalled nationalist organizations mainly address democracy, liberty and equality by reforming and dismantling feudal practices. ${ }^{6}$

The Muhammadiyah as the largest modern Islamic organization which recently celebrated its one hundredth anniversary (1912-2012) is not the first modern Islamic organization. There were many forerunner organizations which had been the inspiration for the Muhammadiyah such as Jamiat Kheir founded by Arab descendants in 1905. There was also an Islamic organization established by prominent Muslim business circles in Laweyan, Surakarta namely Syarikat Dagang Islam (Islamic merchant organization) which appeared to be more political than associated with Islamic orthodoxy. This organization used Islam as the political identity of "the indigenous" against the colonial others through addressing economic domination, labor exploitation and other forms of social ills. ${ }^{7}$ The Syarikat Dagang Islam, otherwise known as SDI, immediately attracted many urban young Muslims, including

5 Dhofier 1985: 1-5.

6 Jayawardena 1986: 3.

7 Noer 1973: 4. 
the founder of the Muhammadiyah, Ahmad Dahlan. It provided the modalities for establishing a modern society. ${ }^{8}$

There was also the more progressive Islamic organization Wal Fajri which was established in the same decade as the Muhammadiyah but lasted no longer than another decade. Susan Blackburn marked its progressiveness in the first women congress 1928 where its women's wing advocated for women's right on divorce and banning polygamy. ${ }^{9}$ Similarly, the SDI suffered from a severe internal conflict between the Muslim and the Communist faction which tragically curtailed its existence even before Indonesian independence in 1945. The shattered SDI marked the decline of Islam as a political force which was subsequently taken over by secular political groups initiated by Javanese intellectuals such as Budi Utomo whose birth is commemorated as the national awakening day. ${ }^{10}$

Unlike the SDI, the Muhammadiyah largely focused on social services to protect the poor from embracing Christianity as promulgated by the Zending (mission). This organization adopted the model of the Zending such as by providing modern religious education, health services, orphanages and economic activities for the poor. ${ }^{11}$ Together with his wife, Siti Walidah known as Nyai Dahlan, Ahmad Dahlan established an independent women organization Sopo Tresno (Those who care) to provide women with economic empowerment and religious teachings. Subsequently, health centers were established along with the orphanages by emulating the Christian mission and simultaneously aiming at curbing its growth. The non-political way of operation demonstrated by the Muhammadiyah gained strong support from many Muslim donors who preferred to adopt so-called "soft politics" as opposed to the "hard politics" exhorted by the SDI. The colonial authorities were also in favour and provided subsidies for its schools and its social activities under the scheme of improving indigenous life. It eventually created tension between the Muhammadiyah and other Islamic organizations, particularly the Sarekat Islam, the later name of the SDI, accusing the former as cooperating with the colonial authorities. ${ }^{12}$ Ahmad Dahlan and the other founders including his wife were denounced as agents of the colonial authorities and Christians who tended to weaken Islam internally.

\section{Gender dimension in Muhammadiyah structure: social basis for gender regime}

As Jayawardena rightly pointed out, women's emancipation had been a package of social reform and nationalist struggle in the Third World, including Indonesia

8 Noer 1973: 4.

9 Blackburn 2007: xxxiv.

10 Alfian 1989: 8-10.

11 Shihab 1998: 126-127.

12 Ibid.: 111. 
whereby women were seen as "the barometer of modernization". As argued earlier, local educated reformers pursued a new social order by confiscating foreign influences, concurrently dismantling the feudal monarchies and modernizing the religious structure. She argued that during the time of the ethical policy, male bureaucrats, missionaries and other reformers were among the prominent figures who advocated modernity through modern education and women's emancipation. However, she cautions that women's emancipation was initially not intended to fully advocate women's rights as perceived by Western feminism but rather to serve the interests of male reformers in creating the image of educated wives for the modern families. The main purpose of educating women was not intended to give them equal rights to men but rather to prepare them to become the educators of a great nation. She argued further that the advocation of women's emancipation was to strengthen the intended social structure rather than to shift gender relations as the basis for equal partnership which she suspected was the in-built conservative bias in social reforms. ${ }^{13}$

Until recently, the above perspective has prevailed even among the majority of women in Indonesia by merely referring to the early work of Kartini, an upper class woman who advocated education for native women to turn them into modern mothers and educators of a great nation. People tend to ignore that what had been initiated was only the start of emancipation and Kartini asserts that "Java was just awakening when Holland was ready to run". "This statement implies that in the future women's emancipation in Java (and Indonesia) might reach the same equal rights as in Europe.

Nevertheless, the major theme in women's emancipation which was subsequently to take place in Indonesia never went beyond Kartini's preliminary initiative. The establishment of women's organizations was mostly to serve better domestic roles and social services for women's practical needs rather than initiating women's strategic and political interests. Feminists who struggled for political and legal rights in divorce and the prohibition of polygamy remained a minority with limited support from so-called independent women such as Putri Mardika (1912) and Isteri Sedar (1929). ${ }^{15}$ Many young nationalist men advocated that a modern nation could only be achieved by equal partnership between men and women and by abolishing polygamy which induced frustration among women. ${ }^{16}$

In Scanzoni's account on the shift of family relations, the ideal for women in early modern Indonesia was the shift from women's position in the property owner and head complement family into the senior-junior complementary. ${ }^{17}$ Independence became the new image of the Javanese middle-upper class family of secular priyayi which heavily relied on the sole financial support of the husband in their positions as

\footnotetext{
13 Jayawadena 1986: 9.

14 Pane 1939: 52.

15 Vreede-De Stuers 2008: 73.

16 Ibid.: 94.

17 Scanzoni 1981: 315.
} 
local bureaucrats, lawyers and educators which fitted into the bourgeois concept of the male breadwinner and the female housewife roles. ${ }^{18}$ Nevertheless, this kind of image did not portray all the women in Java who were culturally segregated into various groups such as pious Muslims otherwise known as santri as opposed to nominal Muslims or abangan and Muslim merchants or wong dagang, as opposed to the priyayi (bureaucrats) and the aristocrats, and the peasants in the villages; a wide economic spectrum. ${ }^{19}$

Each group represented its particular gender construction which fitted into its own socio-economic context. In the wong dagang circle, for example, gender relations were arranged in divergent settings where women's social status derived from their economic roles while men's social status originated from their social and political activities. By contrast, the priyayi were typically patrilocal and their social status was largely determined by the public and economic position of the husband as the head of the family. The wong dagang conversely had a matrilocal character with women's major role in the home-based industry of the fabrication of garments and silver and gold ware which significantly dictated the market. Businesswomen, mbokmase, were in control of the economy and family affairs, including inter-family marriages which were virtually business networks. The combination of the domestic and economic spheres seems to have been alien to capitalist terminology which assumed a permanent association between economics and the public domain. ${ }^{20}$

Within the discourse on Javanese society, the Muhammadiyah has a distinctive position among the social groups of the priyayi, santri and wong dagang. The Kauman people in Yogyakarta, as the social basis of Muhammadiyah, were uniquely characterized as santri-priyayi who were culturally and politically related to the Javanese Royal House of Yogyakarta as pitty bureaucrats in charge of religious affairs. The Kauman was named after the reputation of the kaum iman (pious Muslims) for generations. ${ }^{21}$ Their structural position, however, was not economically adequate to support their families which urged Kauman women to engage in small home industries and economic activities. Unlike Laweyan's mbokmase whose economic role was central, the Kauman women's economic activities were merely considered additional to their husband's income although some of them earned more.

The comparison between Laweyan Surakarta and Kauman Yogyakarta rested upon both their efforts in giving birth to prominent social organizations despite their social differences. As argued earlier, Kauman people were priyayyi-santri while the Laweyan largely represented the wong dagang-santri which distinctively contributed to the different type of social organizations they created. The wong-dagang santri of Laweyan were known as an independent group who distanced themselves from any association with the monarchy and later, with the Dutch colonial authori-

18 Jayawardena 1986: 15.

19 Geertz 1985: 6.

20 Brenner 1998: 9.

21 Darban 2000: 9. 
ties. With their superior economic position, the Laweyan and particularly mbokmase tended to display an antagonistic stand towards the royal court, especially through the common practices of polygamy and having concubines. ${ }^{22}$ Santri attributes such as being haji were loosely adopted to reaffirm their indigenousness and as a means of political resistance against the Western colonialists.

Members of the Muhammadiyah, on the other hand, purposely adopted santri as its identity as they were pious Muslims who persistently observed basic Islamic teachings. They derived their priyayi outlook from their structural position with the Yogyakarta monarchy circles. The ideal priyayi woman was a good housewife who was protected at home and who contentedly received financial support from her husband. Women who were wandering off outside their houses to the markets or to the fields were seen as discourteous and lacking spiritual capacity. ${ }^{23}$ However, gender relations in the Kauman were slightly different from those of the priyayi majority. It was partly because the Kauman priyayi were ranked as middle to lower so that women were urged to work. Woman seclusion, which was a common practice among the priyayi was mostly found in the Kauman.

The spectrum of gender relations Scanzoni developed adequately fitted into the Javanese families. The gender hierarchy among Javanese mainly rested upon the lack of economic roles for women. It was clear that the larger the economic contribution women made the more equal gender relations they enjoyed as indicated in the case of the mbokmase in Laweyan. The absence of mbokmase in the Kauman was a consequence of the priyayi bias which tended to consider the male's structural position as the parameter of social status over women's economic roles. Nevertheless, the economic contribution of women in the Kauman had slightly shifted the seniorjunior complement into a senior-junior partnership which was not elaborated in Scanzoni's typology.

The above expounded gender relations seemed to have been the backbone structure of the Muhammadiyah and appeared to be a model for subsequent Muslim organizations including the Nahdlatul Ulama which was founded a decade later in 1926. During the inception period, Kiai Dahlan and his wife founded two separate organizations, one for men and one for women. The Muhammadiyah accommodated the male activism while the 'Aisyiyah represented female social engagement. The organizations, named after the Prophet Muhammad and his wife, ' $\overline{\mathrm{A}}$ 'isha, intentionally indicated a husband-wife relationship. ${ }^{24}$ It is a clear indication of the expansion of the 'senior-junior partnership' of the Kauman into the public domain of the Muhammadiyah and 'Aisyiyah. 'Aisyiyah was established as an independent organization named "Sopo Tresno" which worked closely with Muhammadiyah in providing education and social services for girls and women.

22 Soedarmono 2006: 112.

23 Brenner 1998: 140.

24 Van Doorn-Harder 2006: 72. 
The amalgamation of Sopo Tresno or 'Aisyiyah into Muhammadiyah's structure in 1922 was, somehow, subordinating its very existence. It was perfectly reflected in the bourgeois nuclear family which was arranged according to gender and age hierarchy in its structure. ${ }^{25}$ Besides, the substitute name Sopo Tresno raised a pertinent question of why ' $\overline{\mathrm{A}}$ ' isha was selected rather than Khadija, the first wife whom the prophet adored most and with whom he remained in a monogamous marriage for over 18 years, or Fatimah, his beloved daughter? According to prominent 'Aisyiyah members the name of the organization was ' $\overline{\mathrm{A}}$ ' isha to signify the new image of Muslim women who are intelligent, smart and socially engaged. Kuntowijoyo asserted that Fatima was intentionally excluded in order to disconnect this organization from the Shiah movement where Fatima had been made a central figure. ${ }^{26}$ When looked at from Denzau and North's perspectives on the shared mental-model which subsequently shapes the ideology in a given institution, ' $\overline{\mathrm{A}}$ ' isha reflected the ideal type of a Kauman woman while Khadija with her major economic role perfectly reflected the mbokmase type in Laweyan. ${ }^{27}$ In other words, Khadija was not part of the "shared-mental model" of the Kauman people as it was in Laweyan. The sharedmental model is the collective body of knowledge in Berger's account which is constructed, reproduced and transmitted within social institutions. ${ }^{28}$

The symbolic order of the Muhammadiyah and 'Aisyiyah somehow secured the gender ideology of the senior-junior partnership of the Kauman community. The later creation of the youth organization Pemuda Muhammadiyah for boys and Nasyiatul 'Aisyiyah for girls secured the concept of the nuclear family in the public domain. The persistence of this structure over a century proves Haevey's idea that the basic structure of a social system in the formative period tends to be institutionalized in such a way that it shapes its future existence and is perceived as fixed and permanent by the next generation. This basic social structure creates a space within the social institution where social interaction is taking place. ${ }^{29}$ The senior-junior partnership as the basic structure of the Muhammadiyah eventually domesticated 'Aisyiyah with women and family matters and subsequently detached them from political issues. The Muhammadiyah holds the authority to represent the subsidiary organizations within its structure, including 'Aisyiyah. Every decision made in the subsidiary organizations should be endorsed by the Muhammadiyah but not the other way around.

The increasing discourse on gender equality in the earlier 1990s raised the consciousness among the younger generation against existing structures and the unequal share of the resources and assets within this organization. Nevertheless, proclaiming themselves as independent organizations has not been the choice of ' $\bar{A}$ ' isha and Nasyiatul ' $\overline{\mathrm{A}}$ 'isha for they are unwilling to be uprooted from the historical context.

25 Spain 1992: 16.

26 Kuntowijoyo 1993: 130.

27 Denzau/North 1993: 2.

28 Berger/Luckman 1979: 15.

29 Heavey 2009: 13-14. 
In 2000, 'Aisyiyah gained wider autonomy to manage schools, health centers and even universities which were previously controlled by the Muhammadiyah as the patron organization. Only in the recent national congress in 2012 in commemoration of the one hundred year anniversary, the Muhammadiyah halfheartedly accommodated the petition memo sent by ' $\overline{\mathrm{A}}$ ' isha demanding female involvement in the $\mathrm{Mu}$ hammadiyah's leadership. The head of the central board of ' $\overline{\mathrm{A}}$ ' isha is officially appointed as one of the thirteen members of the Muhammadiyah Central Board. This decision should subsequently be adopted by the leaderships at the provincial and district levels. This achievement can be seen as substantive progress of this organization in the second millennium. ${ }^{30}$

\section{Gender issues in the official pronouncement}

In more practical issues, the official pronouncement enunciated in the national congress every five years is considered the highest consensus of the Muhammadiyah (keputusan muktamar) which Gramsi defines as a historically organic ideology which is structurally secure and reproduces its basic values, vision and mission. ${ }^{31}$ After gaining wider autonomy, ' $\overline{\mathrm{A}}$ ' isha is capable of launching its own pronouncements not only on women and family matters but also on wider political and social issues. The pronouncements are equally weighted as the highest consensus binding to all members of the Muhammadiyah and its subsidiary organizations. ${ }^{32}$ As far as its recording system is concerned, the Muhamamdiayah has a relatively adequate record system of its pronouncements which can be traced back to 1923, the year of its first national congress. In that period Indonesia as a nation state was not politically known. It is unlikely that ' $\bar{A}$ ' isha followed a similar record system because the documents that could be found dated from around 1932 to 2012.

Below are series of official pronouncements related to gender issues which are arranged according to the decade in which they were made except for the early inception period which is arranged according to a two-decade period:

\section{The cultural movement in the inception stage (1912-1930)}

1912 marked the newly born organization and Mulkhan, the prominent and influential Muhammadiyah member, considers its development until 1923 as the cultural movement in which the Muhammadiyah demonstrated its tolerant, inclusive and receptive character, not only towards Javanese syncretism but more obviously towards Western modernization as well as to Christian missionary activities. ${ }^{33}$ In this

\footnotetext{
30 Interview with Prof Siti Chamamah Soeratno, the head of national board of 'Asyiyah, 19 February 2010.

31 "Keputusan Muktamar Muhammadiyah ke 45 tentang Anggaran Dasar", in: Pimpinan Pusat Muhammadiyah (n.d.): 573.

32 Larrain 1982: 81.

33 Munir Mulkhan 2010: 57-58.
} 
period, the gender dimension was addressed in a relatively neutral manner whereby men and women were granted equal access to education and leadership. Ahmad Dahlan, the founder, had only little to say about women's issues in his few personal messages. He was known as the man of action as opposed to Muhammad 'Abduh, his Egyptian inspiring scholar, the thinker who productively articulated modernization in the Islamic world. During the first congress held in 1923 Dahlan reaffirmed his mission in providing modern education to men and women to improve the Islamic Umma. ${ }^{34}$

The second tenet was the necessity to foster dynamic as opposed to conservative Islam to accommodate modernization and social change, and to be responsive to marginalized groups and evince respect to humanity. His statement that 'any one can follow' indicated equal access and participation of men and women in the $\mathrm{Mu}$ hammadiyah. ${ }^{35}$ In 1927 , the Muhammadiyah emphasized the need to promote modern Islam by adequate education and through economic support in order to prevent the Muslims from lapsing into other faiths due to their absolute poverty and illiteracy. ${ }^{36}$ Moreover, the mission was directed to strengthen the nascent organization to turn modern and become equally responsive to men and women in education and other social activism.

\section{The Sharia Oriented Period (1930-1940)}

This period is considered the sharia regime because the organization was dominated by figures with a shariah background who initiated the establishment of the fatwa section (Majelis Tarjih). ${ }^{37}$ It was a turning point whereby the Muhammadiyah shifted from a social organization of modern Muslims to an Islamic organization which much more heavily relied on theological and normative guidance than ever before. The fatwa section holds the utmost authority to direct the organization's activities. ${ }^{38}$ This time gender was systematically settled and segregated. Women and family issues were entirely confined to the " $\bar{A}$ 'isha's domain while the $\mathrm{Mu}$ hammadiyah was in charge of theological and political interests.

Only a decade after the demise of its founder, Ahmad Dahlan, the gender dimension had mostly targeted women while men seemed to be 'omnipresent' in the embedded masculine structure. ${ }^{39}$ This modern organization had inevitably fallen into what Berque counts as embedded masculinity in Islamic collective leadership. ${ }^{40}$ Gender issues were mostly directed toward controlling women which was para-

34 "Kesatuan hidup manusia: pesan KH Ahmad Dahlan, 1923", in: Munir Mulkhan 1990: 223230.

35 Ibid.: 231-235.

36 Ibid.: 244-245.

37 Interview with Abdul Munir Mulkhan in Yogyakarta, 18 February 2010.

38 Munir Mulkhan 2010: 77.

39 Fatima Mernissi used the word to explain masculinity and patriarchy to control women's bodies in: Mernissi 1991: 4.

40 Jacques Bergue: "Pengantar dalam Bahasa Inggris", in: Vreede-De Stuers 2008: xviii. 
mount in the publication of the Islamic guidance for being a good wife (Toentoenan mendjadi isteri jang berarti) which was for the largest part far from being progressive as initially intended. This pocket book largely depicted women as passive and submissive wives who were confined within the four walls of their houses and whose main duty was serving their husbands and educating their children. It was contradictory to the real life of women in the Muhammadiyah who were socially active and economically empowered as reflected by the life of Siti Walidah, Kiai Dahlan's wife and founder of 'Aisyiyah. Kuntowijoyo asserted that the publication of this book was 'irrelevant to the context' of 'Aisyiyah's progressive spirit during the first 20 years after its inception. ${ }^{41}$ However, this guide book was relatively progressive compared to the Javanese literature on women such as Serat Condrorini and Serat Piwulang Isteri which were generally misogynist ${ }^{42}$ as well as the book Sharh 'uqūd al-lujjayn fi bayān ḥuqūq al-zawjayn (husband and wife rights in Islam) which was largely taught in pesantren of Nahdlatul Ulama. ${ }^{43}$

The other progressive movement was the Tabligh school for girls aimed at producing female preachers which conservative groups resisted as they believed that preaching was the male's natural competence. A female magazine was concurrently published to support the Tabligh's mission and more especially to serve the moderneducated audience among women's priyayi. ${ }^{44}$ In 1933 , the young female organization, Nasyiatul 'Aisyiyah (NA), was established for un-married young girls. ${ }^{45}$

Despite the masculine atmosphere discussed above, a controversial pronouncement which created further so ial unrest was the approval of women to teach a male audience with reference to ' $\bar{A}$ ' isha, the brilliant wife of the Prophet from whom Muslims acquired Islamic teachings. Equally controversial was the consent for women to travel alone in pursuing knowledge and to engage in other activities permitted by sharia. Women were discouraged to participate in street marches which were commonly organized by the Sarekat Islam. The theological justification for this was that the Prophet allowed women to do so only in celebrating Ied festivals. ${ }^{46}$ This pronouncement aimed at disconnecting the Muhammadiyah from any association with the Sarekat Islam which was frequently organizing public demonstrations of workers against the colonialists.

In the legal domain, the Muhammadiyah supported the colonial regulation to abolish child marriage in 1937 but, on the other hand, the initiated marriage registration was rejected. ${ }^{47}$ Vreede-De Stuers indicated that the organization finally

41 Kuntowijoyo 1993: 131.

42 Sukri/Sofwan 2001: 49.

43 Sharh 'uqūd al-lujjayn fì bayān ḥuqūq al-zawjayn was translated and revised by the Forum Kajian Kitab Kuning (FK3) with the new title of Wajah baru relasi suami-istri; Telaah Kitab 'Uqud al-Lujjayn (Yogayakarta 2001: FK3 and LKiS).

44 Kuntowijoyo: "Menghias Islam". Introduction to Munir Mulkhan 2010: 19.

45 Pimpinan Pusat Muhammadiyah (n.d.): 101-103.

46 Jainuri 2002: 146.

47 "Kepoetoesan Conggres Muhammadijah XXVI, 6-13 October 1937 di Yogyakarta", in: Pim- 
joined the other Islamic organizations such as the Sarekat Islam and the Nahdlatul Ulama in refusing the policy which was considered a form of political control over family law. ${ }^{48}$ Vreede-De Stuers argued further that this rejection was partly because the colonial authorities were trying to accommodate the demands of secular-independent women groups, including Isteri Sedar dan Putri Budi Sedjati for the abolishment of polygamy. ${ }^{49}$ The late response of the Muhammadiyah to this issue was seen as a form of cooperation with the colonial ruler. The organization had been suffering from severe criticism from the Sarekat Islam as being too close to the colonial power due to the educational subsidy they received. ${ }^{50}$

\section{Political uprising and ideological contestation (1940-1960)}

In 1945, Indonesia gained political independence which significantly shifted the missions of the Muslim organizations to the newly established nation state. It also shifted the nature of the tensions formerly between indigenous and foreign rulers to internal conflicts among the secular, religious and the communist factions over the national political power which ultimately led to political chaos and the so-called Communist Coup of 1965. Consequently, their organizational pronouncements were largely dominated by political issues.

The gender issues pronounced in this time were heavily politicized and yet domesticated, mainly in response to the political agitation of the Communist Party. During the national congress in 1956, the Muhammadiyah emphasized six pronouncements for women: (a) to encourage women to be good mothers to transfer Islamic teaching to their children and family (b) to intensify their social activism in order to curb the spreading of Communism which was considered detrimental to the Islamic family, qoriyah tobbiyah (the ultimate community) of the Muhammadiyah and the Islamic Umma as a whole. ${ }^{51}$ Moreover, moral panic seemed to pervade in this organization as indicated below:

- Segregating gender in Muhammadiyah schools, including teachers in response to the existing moral crisis.

- Imposing a Muslim outfit on women in order to prevent sexual arousal and moral crisis;

- Advising the government to segregate sport centers and swimming pools for boys and girls;

- Urging the education section to impose a Muslim outfit on women and to assign senior and married male teachers to teach female students. ${ }^{52}$

pinan Pusat Muhammadiyah (n.d.): 95.

48 Alfian 1989: 326.

49 Ibid.

50 Jainuri 2002: 146.

51 "Keputusan Muktamar Muhammadiyah ke 34, 18-23 November di Yogyakarta", in: Pimpinan Pusat Muhammadiyah (n.d.): 164-165.

52 "Keputusan Muktamar Muhammadiyah ke 33, 24-29 Juli 1956 di Palembang", in: Ibid.: 140142. 
Domesticating and targeting women seemed to be a global tendency. As in the Islamic world political decline increased, control over women's bodies tightened. The ultimate maxim signifying women's subordinate position was that women should follow her husband, "either to heaven or to hell" (swargo nunut, neraka katut). ${ }^{53}$ It was in the same manner that the Muhammadiyah responded to the political crisis that followed the banishment of the Masyumi party which was Muhammadiyah's staunch ally in politics, due to the allegation of attempting a coup against President Soekarno. Since then, the Muhammadiyah was politically marginalized from core political power which significantly affected its missions.

\section{Political ambivalence in New Order euphoria (period 1960-1990)}

The New Order Government which was later known as a military regime took power from Soekarno after the alleged Communist coup of 1965 which led to the permanent ban of the party in Indonesia. The new president declared to secure religious life which had been obliterated by the Communists but refused to restore the Masyumi and other religiously affiliated parties. The national ideology of Pancasila was imposed as the ideological basis of the parties to replace religious sentiments. Many political scientists see this period as 'the honeymoon between Islam and the state', particularly the Muhammadiyah despite the dynamic relations of "ebb and flow" in the years to come. ${ }^{54}$

This optimism revealed a progressive and public-oriented direction as far as gender issues were concerned. One of the milestones of the progressivity was granting 'Aisyiyah organizational autonomy with wider control of its asset and organizational pronouncements. ${ }^{55}$ The Muhammadiyah fully supported the effort of the Indonesian Government to pass the national marriage law which was generally seen as consistent with the Islamic principles. The government succeeded in bringing together the Islamic and the secular women organizations to obtain consensus on the national marriage law ${ }^{56}$ which was believed to protect the Islamic Umma. ${ }^{57}$

The Muhammadiyah responded positively to the raise of women education and the increase of political and economic roles for women by launching its second guide book in 1972 which complemented the previous one which mainly dealt with domestic matters. Unlike the previous book which was drafted by the Majelis Tarjih (Fatwa Section), the latter was initiated and endorsed by 'Aisyiyah to be structurally binding to all members of the Muhammadiyah. The guidebook was entitled Adabul mar'ah fil Islam which literally means 'Guidebook for Woman in Islam'. There is

53 Ibid.: vii.

54 Redaksi Suara Muhammadiyah: "Pasang surut politik Orde Baru dan era sesudahnya", Suara Muhammadiyah, No. 01, 1984: 14.

55 "Keputusan Muktamar Muhammadiyah ke 36, tahun 1965 di Bandung", in: Pimpinan Pusat Muhammadiyah (n.d.): 185.

56 See Vreede-De Stuers 2008: 166-167.

57 "Keputusan Muktamar Muhammadiyah ke 38, 17-22 Januari 1975 di Padang", in: Pimpinan Pusat Muhammadiyah (n.d.): 257. 
no record of the reason for using the Arabic title for this book or a sufficient explanation from Muhammadiyah and 'Aisyiyah elites. The book progressively granted women the highest public positions such as city mayor, director, head of police, medical doctor and judge to which conservative 'ulama' ' were opposed. However, Syamsul Anwar argued that the Majelis Tarjih never reached consensus on women's presidency which remained undecided (mawqüf) until 2012. ${ }^{58}$ In responding to the population control policy, the Muhammadiyah endorsed the fatwa of the Indonesian Ulama Council (Majelis Ulama Indonesia), founded by the New Order mainly to offer religious advises to state policies. The use of contraceptive devises was allowed as the means of population control except UID which should only be undertaken by female doctors and the prohibition of vasectomy which caused permanent infertility. ${ }^{59}$

This vibrant progress on women's public engagement lasted only a decade until in 1984 'Aisyiyah launched its third guidebook entitled Tuntunan menuju keluarga sakinah (Guidebook for a Harmonious Family) which feminists considered a huge step back due to its heavy emphasizes on women's domestic roles. According to the head of 'Aisyiyah central board, the Tuntunan book was not intended as a substitute but rather as supplementary to the previous books in order to protect the family and children from the negative impact of rapid social transformation and globalization. ${ }^{60}$ Some elite members of 'Aisyiyah denied this by arguing that the book already existed before the policy on the Program Kesejahteraan Keluarga (family welfare program). ${ }^{61}$ From Gramsi's perspective this book was a form of political hegemony of the New Order to control social organizations concerned with women and the family. The New Order persistently imposed its notion of an ideal woman and ideal family which they made a subject of competition within the framework of the socalled Sakinah Award from the district to the national levels. The ideal type represented the upper priyayi image of a woman who is married and has a modest career but under no circumstances could a wife's career be higher than that of her husband or could she be equally smart in managing household.

A woman's success is determined by her husband's excellent career and the good education of her children, preferably two, a boy and a girl. In reverse, career women would be blamed and held responsible for family breakdowns and children's low achievement. ${ }^{62}$ This step back also reflected on the efforts of the 'Islamization' of the public sphere. In the National Congress of 1990, 'Aisyiyah strongly encouraged the Muhammadiyah to urge the government to remove the prohibition of wearing the veil in public schools. ${ }^{63}$ In the same vein, 'Aisyiyah called for gender

58 Interview with Syamsul Anwar, Head of Majelis Tarjih Pimpinan Pusat Muhammadiyah 20052010 in Yogyakarta, 26 March 2010.

59 Atho Mudzhar 2003: 134-138.

60 Interview with Chamamah Suratno, 19 February 2010.

61 Sullivan 1991: 64.

62 Dzuhayatin 2001: 261.

63 "Keputusan Muktamar Muhammadiyah ke 42, 15-19 Desember 1990 di Yogyakarta", in: 
segregation in sports and in swimming pools. Equally compelling was the regulation for female students in the Muhammadiyah schools to be fully covered. ${ }^{64}$

\section{New path for progressivity (1990-2000)}

The Muhammadiyah seemed to be more progressive and yet accommodative to the state as Western educated cadres dominated its central board such as Amin Rais, Syafi'i Maarif, Wati Pratiknyo, Syafri Syairin and so forth. The political "honeymoon" with the government was in the most desirable stage when many Muhammadiyah cadres were recruited to work in the central and district bureaucracies. They also became actively involved in establishing the new Islamic intellectual organization (ICMI). The Muhammadiyah claimed to significantly infuse moderate Islam into the bureaucracy and even into the military despite allegations of having been co-opted by the Soeharto regime.

This era can be considered as the Muhammadiyah's second birth which was marked by a shift from having been sharia oriented for over three decades to an intellectual based organization. The most pertinent shift was the wider mandate given to the Majelis Tarjih from issuing normative fatwas to progressing toward the formulation of "comprehensive and contextual Islamic thought". This section was transformed into the Majelis Tarjih and Islamic thought (Majelis Tarjih dan Pemikiran Islam) under the guidance of Amin Abdullah, the progressive scholar who had graduated from Turkey. Pluralism, human rights, gender equality, globalization and the environment which all had been alien to and were excluded from fatwas were now vibrantly discussed within the organization. ${ }^{65}$

'Aisyiyah displayed a similar eagerness in response to the global issues of migrant workers and the international conflicts of Palestine, Bosnia, Kenya, Afghanistan and Kashmir. ${ }^{66}$ After having been silent for almost a century, 'Aisyiyah and Nasyiatul loudly raised 'Aisyiyah woman's leadership in the Muhammadiyah which was positively received in the national seminar in 2002 in preparation of the national congress $2005 .{ }^{67}$ It was the first time ever that the issue of women 'imāma (women leading prayers in front of men) was raised despite the strong refusal from both 'Aisyiyah elite members and more obviously, the Muhammadiyah. Morcover, the concept of equal partnership at home as advocated through feminist activists and which opposed the state ideology on motherhood also gained considerable response

Pimpinan Pusat Muhammadiyah (n.d.): 328.

64 Pimpinan Pusat 'Aisyiyah, Tanfidz Keputusan Multamar 'Aisyiyah ke-41 di Surakarta, 7-11 Desember 1985: 17.

65 "Keputusan Muktamar Muhammadiyah ke 43, 6-10 Juli 1995 di Banda Aceh", in: Pimpinan Pusat Muhammadiyah (n.d.): 442.

66 Pimpinan Pusat 'Aisyiyah: Tanfidz Keputusan Muktamar 'Aisyiyah ke 43, 6-10 Juli 1995: 3637.

67 "Keikutsertaan perempuan dalam pimpinan dan permusyawaratan (Konsep Rumusan Dalam ART Muhammadiyah), Tanwir Muhammadiyah di Makasar, 26-29 June 2003”, in: Pimpinan Pusat Muhammadiyah (n.d.): 2. 
of the young generation. The translation of the works of Muslim feminists such as Amina Wadud, Fatima Mernissi, Laila Ahmed and others inspired local female scholars to raise these sensitive issues. This progress created a dynamic contestation between progressive and conservative factions within the organization. While the progressive faction enjoyed its dominant position in the early 1990 s, the conservative group subsequently gained the support of people who suffered from the global monetary crisis and the abusive power of the New Order which led to the reformation movement in 1998.

\section{Tsumami of Salafi incursion (2005-2010)}

The collapse of the New Order regime heralded Reformation that facilitated a freedom of expression which had been prohibited for over three decades. Not only the pro-democracy proponents took advantage of the movement but also many Salafi groups, who had previously been labeled 'extreme right-wing groups' and had been politically curbed in their promotion of the Islamic state, claimed the liberty to do so. The Salafi actively advocated the Islamic state in mosques by offering "spiritual anchors" for the desperate masses. Returning to the sharia and the Islamic state attracted the poor who seemed to be ignorant of the new political elites. Mulkhan rightly pointed out that the advance of Salafi movements constituted a 'Salafi tsunami hit' in the national congress 2005 of the Muhammadiyah in which the progressive proponents were wiped out, including Syafi'i Maarif, the head of the central board who had replaced Amin Rais.

The proposed drafts of current issues, including equal gender relations diminished astonishingly, including the demand for female figures in the Muhammadiyah board. It was apparent that within five years the progressive faction had failed to convey its mission to the grassroots. The Salafi silently took over the $\mathrm{Mu}$ hammadiyah at the provincial and the district levels and eventually also in the central board. It was too late for moderate Muhammadiyah adherents to realize the political agenda of the Salafis who argued against the negative impact of democracy, liberalism, secularism, fundamentalism, radicalism as well as traditionalism. ${ }^{68}$

'Aisyiyah luckily escaped from the Salafis' grip and continued working on promoting gender equality in the Islamic framework. It officially adopted the gender concept after having suffered a decade of internal tension following the enactment of Presidential decree no. 9/2000 on gender mainstreaming. 'Aisyiyah was actively involved in advocating women's rights with NGOs previously suspected of being Western agents who systematically intended to obliterate Islam and Indonesia. 'Aisyiyah's most important achievement in this progressive manner was the publication of the book Memecah kebisuan: Agama mendengar suara perempuan korban

68 Interview with Abdul Munir Mulkhan, 18 March 2010. The rejection of democracy, gender equality and human rights was reflected by Pimpinan Pusat Muhammadiyah's "Keputusan Muktamar Muhammadiyah ke 45, 3-8 Juli 2005 di Malang", in: Pimpinan Pusat Muhammadiyah (n.d.): $533-534$. 
kekerasan demi keadilan (Breaking the muteness: Religions hear the voices of victims of violence against women in the name of justice) in cooperation with the Indonesian Commission on Women's Rights.

\section{Forging the dawn at the turn of the century (2010 - Onward)}

The conservative factions were taking control of the organization from the central to the smallest branches after the national congress in 2005 and many members became active supporters of Partai Keadilan Sejahtera also known as PKS (Justice and Prosperous Party) rather than the Partai Amanat Nasional (National Mandate Party) which was founded by Amin Rais initially to accommodate the political interests of Muhammadiyah members. The central role of the Majelis Tarjih (fatwa section) which had been more progressive in the earlier years was replaced by The Majelis Tabligh (Preacher section) which was dominated by Salafi supporters. In their response to democracy, gender equality and human rights and pluralism they were hostile and alleged them to be new forms of Western imperialism. This hostile attitude raised severe criticism from external parties but more obviously disturbed the internal moderate group which had been silent during the height of battle between the progressive and Salafist factions. ${ }^{69}$ The moderates urged the central board to adopt a decree in 2008 against the Salafi threat to the Muhammadiyah and for the disengagement with the PKS. Subsequently the mosques, universities and the organization were 'cleansed' from Salafi influences.

The ultimate efforts to disconnect with the Salafi rested on the motto of melintasi zaman (to cross the New Millennium) of the national congress in 2010. It saw the return of progressive figures and welcomed the positive engagement with the abovementioned current issues. There were many historical pronouncements as far as gender equality was concerned. Firstly, the consensus of granting a woman to occupy the position of the highest state leadership such as president which had been disputed for over a century. The second and most astonishing pronouncement was the decision made in the Majelis Tarjih's national congress to allow a wife to act as imam to lead prayers in the family if she has better Qur'anic knowledge than her husband. The head of the Majelis Tarjih admitted that this decision might raise internal tension among the various factions within the organization and that it would need some time in order to be fully adopted as a formal pronouncement by the central board of the Muhammadiyah. ${ }^{70}$ Thirdly, the success of 'Aisyiyah in promoting female leadership in the central board of the Muhammadiyah which had been repudiated at the previous congress. The Majelis Tarjih also confidently adopted monogamous marriage as the basis of the Muhammadiyah and increased the marriage

69 Interview with Munir Mulkhan, former Secretary General of the Muhammadiyah 2000-2005, 18 March 2010.

70 Interview with Syamsul Anwar, the head of the Majelis Tarjih in the national congress in Malang, East Java, 4 April 2010. 
age to the minimum of 18 years in accordance with the Child Protection Bill no. $24 / 2003$.

\section{Conclusion}

This paper demonstrates the complex and systematic ways how gender has been ingrained and embedded in a social organization like the Muhammadiyah. In a society where religion is prevailing like Indonesia the gender regime in the largest Islamic organizations Muhammadiyah and Nahdlatul 'Ulama are the main source for state policies and regulations which constitute that regime. It is, therefore, imperative to study the gender regimes in social organizations which apparently show dynamic, dialectic and yet contested relationships with socio-political and economic development. The progressive movement which is currently prevailing in the $\mathrm{Mu}-$ hammadiyah can become a substantive basis for encouraging the Indonesian Government to endorse gender equality policies which have been adjourned due to the controversy instigated by conservative and Salafi groups. The main concern has been the notion that gender equality fundamentally contradicts the teachings of Islam where men are given a superior position over women. The decision made in the 2010 national congress that granted a wife to become the imam during family prayers for her husband and her family may forge a new dawn for the promotion of gender equality in Indonesia.

\section{Bibliography}

Alfian (1989): Muhammadiyah: the political behavior of a Muslim modernist organization under Dutch colonialism. Yogyakarta: Gadjah Mada University Press.

Atho Mudzhar, Muhammad (2003): Islam and Islamic law in Indonesia: a socio-historical approach. Jakarta: Ministry of Religious Affairs.

Bantanī, Sheykh Nawawī al-: Sharh 'uqūd al-lujjayn fì bayān ḥuqūq al-zawjayn. (many editions)

Berger, Peter and Thomas Luckman (1979): The social construction of reality. London: Penguin.

Blackburn, Susan (2007): Kongres perempuan pertama: tinjauan ulang. Jakarta: Yayasan Obor.

Brenner, Suzanne (1998): The domestication of desire: women, wealth and modernity in Java. New Jersey: Princeton University Press.

Connell, R. W. (1987): Gender and power. Stanford: Stanford University Press.

Darban, Ahmad Adaby (2000): Sejarah Kauman: menguak identitas kampung Muhammadiyah. Yogyakarta: Terawang.

Denzau, Arthur and Douglas C. North (1993): Shared mental models: ideologies and institutions, http://www.jstr.org/journal.aea (accessed on 11 February 2013). 
Dhofier, Zamakhsari (1985): Tradisi pesantren: studi tentang pandangan hidup kiai. Jakarta: LP3ES.

Dzuhayatin, Siti Ruhaini (2012): Rezim gender Muhammadiyah: kontestasi gender, identitas dan eksistensi, Doctoral thesis, unpublished.

- (2001): Gender and pluralism in Indonesia, in: Robert Hefner, The politics of multiculturalism: pluralism and citizenship in Malaysia, Singapore and Indonesia. Honolulu: University of Hawaii Press, 255-267.

Forum Kajian Kitab Kuning (FK3) (1985): Wajah baru relasi suami-istri: telaah kitab 'uqud al-lujjayn. Yogayakarta: FK3 and LKiS.

Geertz, Hildred (1985): Keluarga Jawa. Jakarta: PT Temprint, 6.

Heavey, David (2009): Geographies of justice and social transformation. Athens: University of Georgia Press.

Jainuri, Ahmad (2002): Ideologi kaum reformis. Surabaya: Elpam.

Jayawardena, Kumari (1986): Feminism and nationalism in the Third World. London: Zed Books.

Kuntowijoyo (1993): Arah pengembangan organisasi wanita Islam Indonesia, in: Lies M. Marcoes-Natsir \& Johan Hendrik Meuleman (eds.), Wanita Islam Indonesia dalam kajian tekstual dan kontekstual. Jakarta: INIS.

Larain, Jorge (1982): Concept of ideologies. London: Hutchinson.

Mernissi, Fatima (1991): Women and Islam: an historical and theological enquiry. Oxford: Blackwell.

Munir Mulkhan, Abdul (1990): Pemikiran K. H. Ahmad Dahlan dan Muhammadiyah. Yogyakarta: Bumi Aksara.

- (2010): Marhenis Muhammadiyah. Yogyakarta: Galang Press.

Noer, Deliar (1973): The modernist Muslim movement in Indonesia. London: Oxford University Press.

Pane, Armijn (1939): Habis gelap terbitlah terang. Jakarat: Balai Pustaka.

Parekh, Bikhu (2008): New politics of identity: political principles for an interdependent world. Palgrave: McMillan.

Pimpinan Pusat Muhammadiyah (n.d.): 95 tahun langkah perjuangan. Yogyakarta: PP Muhammadiyah.

Scanzoni, Letha Dawson and John Scanzoni (1981): Men,women and change: a sociology of marriage and family. New York: McGraw-Hill Book Company.

Shihab, Alwi (1998): Membendung arus: respon gerakan Muhammadiyah terhadap penetrasi misi Kristen di Indonesia. Bandung: Mizan.

Soedarmono, Mbakmase (2006): Pengusaha Batik di Laweyan Solo awal abad 20. Jakarta: Yayasan Warna-warni.

Spain, Daphne (1992): Gendered spaces. Chapel Hill: The University of North Caroline Press.

Sukri, Sri Suhanjati and Ridin Sofwan (2001): Perempuan dan seksualitas dalam tradisi Jawa. Yogyakarta: Gama Media.

Sullivan, Norma (1991): Gender and politics in Indonesia, in: Maila Stiven (ed.), Why gender matters in Southeast Asian politics. Melbourne: Monash University.

Van Doorn-Harder, Pieternella (2006): Women shaping Islam: reading the Qur'an in Indonesia. Chicago: University of Illinois Press.

Vreede-De Stuers, Cora (2008): Sejarah perempuan Indonesia: gerakan dan pencapaian. Jakarta: Komunitas Bambu. 


\title{
Indonesian tafsìr on polygamy, qawwām and $n u s h \bar{u} z-$ the examples of Hamka and Quraish Shihab
}

\author{
Fritz Schulze
}

The position of women in society occupies center stage in any Islamic discourse on the suitable structure of an Islamic polity. Beside questions of morality and proper behaviour in the public sphere - among others decent clothing - there are questions of inheritance, cross-religion marriages, political leadership, and so on. The issues of polygamy, qawwām (leader, custodian) and nushüz (disobedience), i.e. the position of women within the family context, are an integral part of this discourse. This discourse is carried on emotionally for it affects the very core of women's rights. It would be beyond the scope of this article to draw a comprehensive picture of this discourse. Sources are abundant, and a detailed depiction and analyses would fill several books. In this paper I want to shed some light by giving an analysis of debate strategies which are implemented by two prominent Indonesian scholars. Further, I want to show that these three issues figure differently concerning relevance and positioning.

To put it into a framework we must first distinguish between different types of discourse. One type, which is prevalent today, is adjunct to the interpretation of the Qur'an and the Hadith. The other type is part of a broader discourse in society. This analysis will show that the latter type is much more embedded in the local context than the former. However, a clear dividing line cannot be drawn.

I want to start with one type of reference which is used for the both types of approaches, that is the complete take-over of positions generated outside Indonesia. With respect to Qur'anic tafsir and Hadith this method is very old and was formerly extensively practiced, both in the form of original Arabic language texts as well as in translations. The old tafsïr-literature and the so-called kitab kuning $^{1}$ are a vivid example for this. But also interpretations based on a contextualization in time and space we find in this type of discourse. One example is the booklet Kritik atas jilbab written by the Egyptian Muhammad Sa'īd 'Ashmāwī', a retired Supreme Court Justice, which was translated from the Arabic by Jaringan Islam Liberal in 2003. Likewise an example is Khaled Abou El Fadl, a born Kuwaiti and now professor of law at the University of California in Los Angeles. His book Speaking in God's

1 Literally "yellow book"; text books used in Indonesian Islamic boarding schools.

2 The rendering of the original title is faulty. 
name: Islamic law, authority, and women was translated in 2004 into the Indonesian language.

Concerning the original Indonesian tafsìr-literature I choose the Tafsir al-Azhar as an example, written by Hamka. It was finished in 1967 and is still influential. Generally speaking, we can say that Hamka rarely refers to contemporary authorities. At the beginning of süra al-nis $\bar{a}^{\prime}$ he refers to the modernist interpretations of Muhammad Rashīd Riḍa and Muhammad 'Abduh when discussing the creation of Adam and Eve ${ }^{3}$. We should keep in mind that Hamka was a leader of the modernist Muhammadiyah which drew heavily on ${ }^{\mathrm{c}}$ Abduh and especially on Riḍa since it was founded in 1912. But turning to verse 2 and 3, which is concerned with polygamy he exclusively refers to classical authorities including Hadith and relies on his own interpretation. ${ }^{4}$ For him the asbāb al-nuzūl are the core of his interpretation that the permission of four wives was given in a specific historical and social context. This claim is substantiated by three Hadith originating from ' $\bar{A}$ 'isha. Important is his argument that polygamy is bound to certain preconditions, especially equity and justice, which are set in the Qur'an itself. If these conditions are not met only one wife is allowed. And since these conditions are rarely met one wife is the norm and not the exception. The allowance to take an additional slave girl which is also permitted in verse 2 is by Hamka completely relegated to a historical context which nowadays isn't relevant any more: no slaves today also means no slave girl as concubine. Strangely enough, although slavery is not directly called into question by the Qur'an or by the prophet, it is relegated by Hamka to a gone-by social system whereas other social features may not be questioned at all, including polygamy. In any event, according to Hamka polygamy is permitted, although under certain conditions.

Whereas the chapter on polygamy is rather extensive in Hamks's tafsir, the

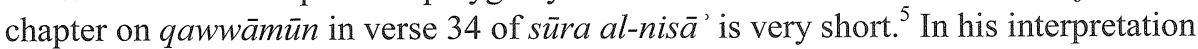
he neither refers to any mufassir nor does he draw on any Hadith. That means he exclusively relies on his own interpretation. That does not mean, by the way, that no other mufassir shares his opinions. The verse on qawwämūn is no prescription given to mankind by God, he says. He calls it, instead, kenyataan (undisputable fact). That means, for him, the position of males as qawwämün is something like natural law; something which is not only part of human nature but also widespread in nature. He gives the example of ducks where the male duck is also leading a flock of females.

Although the notion of nush $\bar{u} z$ is mentioned in the same Qur'anic verse as qawwāmūn, nush $\bar{u} z$ is interpreted separately by Hamka. ${ }^{6}$ In contrast to his interpretation of qawwāmūn he heavily draws on other, classical mufassirūn, but only when it comes to the phrase wa-dribühunna ("then beat them"). The first two modes to teach

3 Hamka 1984, Juzu' 4: 218.

4 Ibid.: 223-259.

5 Hamka 1984, Juzu' 5: 45-48.

6 Ibid.: 48-53. 
a disobedient wife - to admonish her and then to ignore her in bed - is easily explained. But for "to beat her" he explains it by citing fuqahä' and mufassirün, none of them from contemporary times. All his explanations revolve around the questions when it is proper to beat one's wife and how to beat her. Of course, he comes to the conclusion that a wife must only be beaten after the first two modes of teaching had been of no avail: "... only to a woman who really deserves it!"”. After that there are several advices: not to beat the face, not to break her bones, restriction of instruments, and so on. All in all, beating should be avoided but exercised if necessary.

Before coming to my first conclusion I would like to turn to another Indonesian 'älim, Muhammad Quraish Shihab. He is a well known contemporary scholar and his books are widely read in Indonesia. He has written two traditional tafsirs, i.e. al$l u b \bar{a} b^{8}$ and $a l-m i s \underline{b} \bar{a} h^{9}$ which both interpret the Qur'anic verses one by one, and one thematic tafsìr titled Wawasan al-Quran. ${ }^{10}$ But first I want to have a look at another of his books titled Perempuan, which means Women and was first published in 2005. In this voluminous book he discusses everything which has to do with women and gender from an Islamic point of view, including, of course, polygamy, qawwām and nushüz. Al-lubāb which means "quintessence" is a relatively short tafsìr in four volumes. Al-mișbạh (literary "luminary" or "light"), on the other hand, is very voluminous and comprises 15 volumes. Wawasan al-Quran (literally "concepts of the Qur'an") is arranged in one volume according to thematic items including a chapter on women.

As with Hamka the part on polygamy is much more elaborated than the other two. Basically the position of Quraish Shihab doesn't differ much from Hamka's. He states that polygamy is no prescription rather a possibility which can be used in certain circumstances. This being so, Quraish Shihab states that there are ample possibilities for the state to determine the legal conditions for polygamy. In this point he, indeed, differs from Hamka who does not take into account contemporary legal aspects. Other than Hamka, Quraish Shihab emphasizes that the state may provide provisions which go beyond the standards of the prophet's time. Here he refers to the example of 'Umar, the second $k$ hali $f a$ '1 , and underscores his view by quoting the well known Egyptian 'alim Abu Zahra (d. 1974). ${ }^{12}$ All in all Quraish Shihab advocates a limited polygamy. He criticizes those who endorse full polygamy and accuses them of only to have in mind their own sexual desires using the script and the example of the prophet as a pretext. But he even more strongly criticizes those who want to abolish polygamy at all. He accuses them of arbitrarily interpreting the Holy Qur'an for the sake of their own interests as well. He himself

7 “... hanya dilakukan kepada perempuan yang sudah memang patut dipukul!” (Hamka 1984: 50 ).

8 Shihab 2012.

9 Shihab 2009.

10 Shihab 2013.

11 Ibid.: 200.

12 Ibid.: 199-200. 
refers to the ruling of "banyak ulama dewasa ini", that means "many contemporary 'ulamā'", without any specification. Second he uses the same arguments as Hamka, depicting polygamy as something as natural law which is valid everywhere and at all times. Polygamy is, according to both, indispensable for several reasons which are often brought forward by the proponents of polygamy, especially the fact that there are more females than males in the world, in order to fight prostitution, the differing mental predispositions of men and women, and so on. Therefore polygamy isn't a manifestation of female submission but, instead, something which both sides, male as well as female, could benefit from under certain conditions.

In his shorter Tafsìr al-lubāb Shihab only tells us that polygamy is no prescription but a possibility to avoid certain difficulties: "... menghadapi kasus-kasus yang sulit"13. Further, the economic capabilities should be taken into account. In his thematic tafsīr Wawasan al-Quran Shihab does not refer to any mufassirün other than himself. There is no reference any more to the realm of "natural law" or to nonMuslim societies. Shihab stresses here that the quantity of four wives is a restriction and no increase in number. ${ }^{14}$ Further, polygamy is no question of good or bad but a legal option which is applicable under certain circumstances. ${ }^{15}$ In his Tafsir almișbāh his positions are virtually the same. Even his arguments are partially the same, i.e. he mentions West German women who allegedly demand the legalization of polygamy ${ }^{16}$, the fact that there are more women than men on earth etc. He adds some more arguments such as the potential for reproduction is more extended for men than for women (menopause and menstruation). Infertility and severe illness constitute further arguments. Interestingly, the latter arguments could also be true for polyandry. But, according to Shihab, this is not possible because of the different psychological predispositions of males and females. The male is by nature polygamy-oriented and the female monogamy-oriented. Beside this, if a woman has sexual intercourse with more than two males the sperm would be spoiled and not clean any more with the possible result of illness. ${ }^{17}$ At this point Shihab isn't consistent any more. On the one hand he tells us that polygamy is an exception with no easy preconditions, on the other hand he tells us that polygamy is something natural.

With respect to polygamy Shihab doesn't refer to any outside sources, neither from the West nor from the Islamic world.

\section{Analysis}

When analyzing both Hamka's as well as Quraish Shihab's position on polygamy a very interesting aspect becomes discernible: Western culture is made a point of

\footnotetext{
13 Shihab 2013: 167.

14 Ibid.: 264-65.

15 Ibid.: 266.

16 Shihab 2009: 411.

17 Ibid.: 414.
} 
reference. Both (Shihab only in his book Perempuan, not in his three tafsirs) state that polygamy has always been prevalent in all cultures including the Western. The abolishment of polygamy has had a very bad impact on society. Therefore many people in the West are now well aware that polygamy could be a solution for many societal problems. Quraish Shihab even tells us that many women in West Germany have demanded the legalization of polygamy: "So many women in West Germany call for the legalization of polygamy ..." $" 18$ So, if already Western women are in favour of polygamy there can only be one conclusion: "What Islam offers is, indeed, much more humane and moral compared with what is happening in the middle of societies which prohibit polygamy." 19 Nota bene he equates in this case Islam and his own opinion. The difference between Hamka and Shihab is that Hamka integrates his interpretations on society into his tafsir. Shihab elaborates on this aspect in his book Perempuan but not in his three tafsitrs.

Before coming back to this point, I will have a look on Quraish Shihab's interpretation of qawwām and nushūz. Concerning qawwāmūn Quraish Shihab's ${ }^{20}$ opinion slightly differs from Hamka's. For him qawwām is more a question of responsibility. A husband has no right to enforce his leadership without arguing. The notion of arguing is the principal aspect of leadership. He even goes so far that a wife may take over leadership within her household if her husband isn't able any more. Quraish Shihab quotes two Hadith in support of this. In one of them the prophet points out that everybody within the Umma is a leader including housewives who have responsibility within their households and with respect to their children. ${ }^{21} \mathrm{He}$

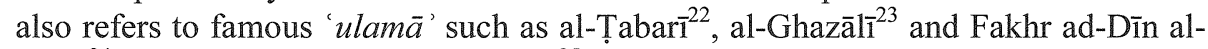
Rāzī. ${ }^{24}$ In his Tafsīr al-miṣbāh Shihab ${ }^{25}$ again stresses that qawwām encompasses a variety of responsibilities beside the male's rights based on having paid the dowry and his wife's costs of living. Here again, as with respect to polygamy, Qur'anic verses are corroborated by natural law, i.e. male and female predispositions. For this purpose he refers again to Western scholars - besides several classical and modern 'ulama' - to confirm his views. Beside two psychologists, Prof. Reek from America and Cleo Dalon ${ }^{26}$ which is cited from a third source ${ }^{27}$ he mentions Anton Nemilov (not Nemiliov as he writes) $)^{28}$ and Maurice Bardeche. ${ }^{29}$ Nemilov was a propagandist

18 ,sekian banyak perempuan di Jerman Barat mengimbau agar poligami dapat dibenarkan ...“ (Shihab 2011: 186).

19 “... apa yang ditawarkan Islam sungguh jauh lebih manusiawi dan bermoral dibandingkan dengan apa yang terjadi di tengah masyarakat yang melarang poligami..." (Shihab 2011: 198).

20 Shihab 2011: 367-376.

21 Ibid.: 371-372.

22 Ibid.: 369.

23 Ibid.: 370 .

24 Ibid.

25 Shibab 2009: 509-517.

26 Shibab 2009: 514-15.

27 Both of them I couldn't trace.

28 Ibid.: 2009: 513. 
of Stalinist world views in the 1920s who thought that women are prisoners of their hormones and that therefore their psyche cannot be compared with the male one. Maurice Bardeche is a prominent figure of French neo-fascism and an admirer of Adolf Hitler. Beside these somewhat strange Western witnesses he cites several classical mufassirūn.

In his book "Perempuan" Quraish Shihab's explications on $n u s h \bar{u}{ }^{30}$ concentrate on the right of a husband to beat his wife. Although at the end he states that nowadays in educated families beating is no proper act any more ${ }^{31}$, he doesn't rule it out totally. Any way, he is not in favour of it. His explanations are not always very clear. On the one hand he explains that the word daraba does not necessarily mean "to beat". On the other hand he refrains to formulate his own idea what the real meaning should be. He quotes two classical 'ulama' who are against beating, namely Ațā' and Ibn al-' Arabī, as well as the prophet himself who spoke out against beating wives. ${ }^{32}$ The essence of his elaborations is that there are two meanings. But if somebody beats his wife he should do it without injuring her. ${ }^{33}$ Strangely enough, he also refers to an Egyptian Professor of Law, Muhammad Beltaji, who on his part quotes a Japanese Prime Minister, Kakoi Tanaka, who instructs his son in law that beating his wife, i.e. his own daughter, would be good if necessary. Afterwards she would love him even more. ${ }^{34}$ Here once again, we see a reference to a non-Muslim society.

In his Wawasan al-Quran beside the Qur'an and the mufassirün he only refers shortly to psychologists in general without further elaborating who allegedly corroborate his views: "The psychologists think that females are guided by sentiment whereas males are guided by reason." ${ }^{35}$ Nushüz he doesn't mention at all in this tafsìr. In his book al-lubāb Shihab makes no reference to psychologists any more with respect to qawwām but, instead, stresses the function of the husband to aliment his wife and family and to pay the dowry. ${ }^{36}$ And, further, the husband should take his decisions only after consulting his wife. ${ }^{37}$ In contrast to his "Wawasan..." nushüz is mentioned here but only very short. The only thing added beyond the mere Qur'anic prescriptions is, again, that the husband should not injure his wife when beating her. ${ }^{38}$

29 Ibid.: 515 .

30 Shibab 2005: 318-326.

31 Ibid.: 326.

32 Ibid.: 325.

33 Ibid.: 326.

34 Ibid.: 324-325.

35 „Sementara psikolog berpendapat bahwa perempuan berjalan di bawah bimbingan perasaan, sedang lelaki di bawah pertimbangan akal." (Shihab 2013: 279).

36 Shihab 2012: 181.

37 Ibid.: 182.

38 Shihab 2012: 182. 
Concerning nushüz there is no clear concept discernible in his Tafsīr al-mișbāh $h^{39}$. He dwells on his opinion that daraba has several meanings and not only "to beat". But in the following text he does not elaborate any more on other meanings than "to beat". His opinion isn't clear. On the one hand he cites 'ulam $\bar{a}$ ' like Ibn al-'Arabī who are against beating. On the other hand he asks: "Is there any better measure which can be used to safeguard family harmony than beating ... after reprimanding and ignoring her in bed have yield no results?" 40 He gives his own answer: "Don't say that beating isn't relevant any more nowadays since scholars of pedagogics still acknowledge it." ${ }^{.11}$ These scholars of pedagogics are obviously of the same brand as the above cited psychologists. At the end he cites Muhammad Țāhir Ibn 'Āshūr that the state should prevent the misuse of this Qur'anic regulation, i.e. if somebody uses his right to beat his wife in an improper way. ${ }^{42}$ Shihab doesn't refer to any contemporary ' $u l a m \bar{a}$ ' or Western sources when discussing the issue of nushüz.

\section{Conclusions}

What can we learn so far? Both Hamka and Quraish Shihab have similar approaches, although they do not always share the same opinion. As far as polygamy is concerned both heavily dwell on arguments developed on historical and societal grounds. They argue that polygamy is no prescription given by God but a possibility tied to certain circumstances and preconditions which are rarely met. From an epistemological point of view there emerges one difficulty: Since polygamy is neither prescribed nor forbidden, how can we find a solution how to deal with it? The answer given is twofold. First, there is room to take own decisions for the ruler or the state; the khalifa Umar is mentioned as an example. Second there is human mankind as a point of reference or, even beyond this, God's creation as a whole, the universal order of things. Above I called it natural law. Arguing this way the Islamic order of things, especially society, is not separated any more from the order of things in general. Prohibition of polygamy becomes therefore a deviation from natural law which is set by God even for non-human beings. From this point of view the reference to non-Muslim societies, especially Western society, becomes logical and is part of the discourse strategy. The reference to non-Muslim societies is also a means to deprive the proponents for an abolishment of polygamy of one crucial argument: If there is room for states and rulers to go beyond the conditions of the Islamic soci-

39 Shibab 2009: 517-521.

40 „Adakah pemecahan lain yang dapat dikemukakan demi mempertahankan keharmonisan rumah tangga yang lebih baik daripada memukul ... setelah nasihat dan meninggalkannya dari tempat tidur tidak berhasil?" (Shibab 2009: 520).

41 „Jangan pula berkata bahwa memukul tidak relevan lagi dewasa ini karena pakar-pakar pendidikan masih mengakuinya." (Ibid.: 520).

42 Shihab 2009: 521. It should already be mentioned here that the Indonesian state outlaws any kind of domestic violence (see below). 
ety of Muhammad's time and to abolish polygamy at all, the view on the consequences in non-Muslim societies which practice this abolishment show the pointlessness of these arguments. The discretionary power of the lawgiver must not violate the order of things which is independent from the individual society. Therefore the first answer - the discretionary power of ruler and states - is invalidated: Polygamy cannot be abolished because it is part of the order of things, i.e. the order created by God. From this point of view the argumentation reaches beyond the specific Islamic context. Western societies, including the Japanese, and even examples from the animal world constitute the framework providing a point of reference. Interestingly, this is not true for indigenous traditional societies of the Indonesian environment. Traditional Indonesian societies are prone to polygamy which is inherited from pre-Islamic times. So, the question arises, why these societies are not taken as a point of reference. This question I cannot answer so far. Are these societies too close as to provide a reference without connotations directly affecting the message which is intended to be conveyed? Is it less risky to take examples, negative or positive, from the Western culture and even from the realm of other creatures than refer to the polygamy of Javanese aristocrats or a Minangkabau datuak? Further research will hopefully bring some results.

The arguments concerning qawwām point towards a similar direction as those concerning polygamy. That means the position of a husband as qawwām is also seen under a functional aspect and not a pure religious one, although the position of the husband within family is one of the preconditions for establishing an order of society which is the basis of a true Islamic polity. Therefore the arguments are more confined to the Muslim society itself. The reference to non-Muslim societies, let alone the wider creation, is therefore pointless. The position of husband and wife within the family is consequently depicted as an achievement of Islam, especially if compared with pre-Islamic and non-Islamic societies.

The question of $n u s h \bar{u} z$ and especially of beating are predominantly seen as a discussion within the Islamic discourse. The treatment of disobedient wives is discussed under an ethical point of view, which comes from within the religious discourse. A reference to non-Islamic societies would be useless here as well. Therefore this discussion is heavily underpinned by traditions of the prophet, that means Hadith, as well as positions expressed by other ' $u l a m \bar{a}$ ' in history and nowadays.

The question of beating is a sensitive one. Therefore, both say it is better not to beat, but none of them is prepared to endorse an abolishment. Since the possibility of beating is given, at least according to their opinion on the basis of their interpretation of religious sources, it cannot be abolished totally. Only the ethical commitment to avoid or to restrict beating is accepted and stressed. At this point we have an interesting link with the social and political reality of Indonesia. This is significant because all tafsir which are discussed here have no explicit connection with societal developments in Indonesia. This is most probably aimed at underscoring the eternal validity of Qur'anic interpretations, detached from time and place. Indonesia, on the other hand, is not at all detached from time and place. Indonesia is committed to 
rnational laws and conventions. One of them is CEDAW on women's rights. lers are the Universal Declaration of Human Rights which enshrines equality and 1-discrimination. Based on these conventions Indonesia issued amongst others a on "the eradication of domestic violence" 43 , which was signed by President gawati on 22 September 2004. According to this law any exertion of domestic lence is prohibited against anybody but "especially women" $44(\S 1.1)$. This vioze is defined as actions which "result in physical, sexual or psychological sufferor pain" 45 The law is explicitly based on the principle of honouring human its, justice, gender equality and non-discrimination ${ }^{46}$. Of course, Shihab does not zuss such laws. But he must have been well aware of them. His interpretations of vwām and nushüz run against this law und must therefore be interpreted as an zrent criticism and that the law is against Islamic principles. He even brings ford that nowadays psychologists would be in favour of beating (see above). It uld also be mentioned that he doesn't take into account the discussion about books still widely used in Indonesian pesantren. For example, Syeikh Nawawi 3antani in his textbook 'Uqūd al-lujjayn lists eleven reasons to beat one's wife. ${ }^{47}$ lough Shihab wrote a preface for a critical study on this textbook ${ }^{48}$ he was not jared to criticise the viewpoints of Syeikh Nawawi directly.

In the case of polygamy there is less dissent since Shihab himself states that the e has the right to determine the legal conditions for polygamy as long as he sn't outright prohibit polygamy. And that is exactly the case in Indonesia. Polyxy is regulated but not prohibited. The question whether this status quo is equally inst gender equality, justice and non-discrimination is not touched here. Shihab lldn't do and the state until now sees no necessity to touch upon this problem.

Hamka's and Quraish Shihab's interpretations on polygamy are not unique. Conling the interpretation of polygamy the tafsir-approach of Hamka and Quraish hab meets with the traditional contextual approach. The contextual approach was e in common as long as the justification of traditional attitudes was concerned. I y want to mention one example which was elaborated by Ro'fah Mudzakir from UIN Yogyakarta. In her article "The Indonesian Muslim women's movement the issue of polygamy: the 'Aisyiah interpretation of Qur'an 4:3 and 4:129" she lyses the 'Aisyiah approach to this question. For us of importance is the time re and around independence. When 'Aisyiah was founded in 1917 as Muimadiya's women's organization there was a speedy development of women's mizations in general in the Netherland's Indies in particular. Besides 'Aisyiah

\footnotetext{
,Undang-undang Republik Indonesia nomor 23 Tahun 2004 tentang Penghapusan kekerasan Jalam Rumah Tangga“" (UU 23 2004).

,terutama perempuan“ (UU 23 2004: §1.1).

,yang berakibat timbilnya kesengsaraan atau penderitaan secara fisik, seksual, psikologis“ (UU '3 2004: $\$ 1.1)$.

JU 23 2004: $§ 3$.
}

:f. Forum Kajian Kitab Kuning 2005: 111-112.

shihab 2005a. 
there were nationalist and secular organisations which were heavily influenced by Western ideas of women's rights. For the Islamic organisations it was, therefore, not only a question of providing a distinct attitude concerning their position in a society which was fighting for social justice, modernization, and even independence. The question was one of social identity. Within this discursive framework 'Aisyiah had to provide an Islamic outlook, distancing itself from Western cultural ideas. One important issue within this discourse was polygamy. To put it in other words: Polygamy became a means of religious and social identity. With respect to the non-Muslim population and addressing a predominantly abangan Muslim population, this could not be achieved by extensive tafsir and Hadith-studies. The mode of argumentation was similar to that of Hamka and Quraish Shihab. 'Aisyiah's justification of polygamy before and around independence was therefore based predominantly on ethical and moral arguments. The social context not only determined the addressee of the discourse but was also the point of reference of argumentation. It wasn't the time for any kind of critical evaluation but, instead, the time for a justification of own traditional values which - with respect to polygamy - were called into question by other social groups. We could argue now, that exactly Hamka as mufassir interpreted polygamy likewise within the framework of his tafsìr. His main arguments show a clear tendency towards the direction of contextualization without literal or speculative interpretations of the Qur'anic verses. Therefore his tafsìr is not typical for a traditional tafsir-approach. This is in the end also true for Quraish Shihab. Both refer to the Qur'an and sunna of the Prophet. But their approach is less doctrinal than contextualized as can be seen from their arguments of natural law and so on. In order to defend traditional attitudes and notions this is sufficient and proper. On the other hand any discourse directed to change must turn to a re-interpretation of the Qur'anic verses and the sunna. A mere reference to the societal context would most probably not be sufficient. This is true for liberal changes as well as mutatis mutandis for Salafi conservatism. This thesis, of course, has to be corroborated by further research.

\section{References}

'Ashmāwī, Muhammad Sa īid al- (2002): Haqīqa al-ḥijāb wa-hujjīya al-hadīth. Al-Qāhira: alKitāb al-Dhahabī.

Asymawi, Muhammad Sa'id al- (2003): Kritik atas jilbab. Jakarta: Jaringan Islam Liberal.

Fadl, Khaled M. Abou El (2003): Speaking in God's name: Islamic law, authority, and women. Oxford: Oneworld Publications.

- (2004): Atas nama Tuhan: Dari fikih otoriter ke fikih otoritatif. Jakarta: Serambi.

Forum Kajian Kitab Kuning (2005): Kembang setaman perkawinan - Analisis kritis kitab 'Uqūd al-lujjayn. Jakarta: KOMPAS.

Hamka 1983: Tafsir al-Azhar, Juzu' 4. Jakarta: Pustaka Panjimas, (reprint 1987).

—: Tafsir al-Azhar, Juzu' 5. Jakarta: Pustaka Panjimas, (reprint 1993). 
Mudzakir, Ro'fah (2005): The Indonesian Muslim women's movement and polygamy, in: Abdullah Saeed (ed.), Approaches to the Qur'an in contemporary Indonesia. Oxford: Oxford University Press, 175-192.

Nawawi al-Bantani (n.d.): 'Uqūd al-lujjayn fí-bayān huqūq al-zawjayn. (Many editions).

Shihab, M. Quraish (2005): Perempuan. Jakarta: Lentera Hati, (reprint 2011).

- (2005a): Pengantar, in: Forum Kajian Kitab Kuning, Kembang setaman perkawinan Analisis kritis kitab 'Uqūd al-lujjayn. Jakarta: KOMPAS, xiii-xxii.

- (2009): Tafsìr al-miṣbāh - Pesan, kesan, dan keserasian al-Qur'an, new edition (5 $5^{\text {th }}$ print 2012), vol. 2. Jakarta: Lentera Hati.

- (2012): Al-lubāb - Makna, tujuan, dan pelajaran dari surah-surah al-Qur'an, vol. 1. Tangerang: Lentera Hati.

- (2013): Wawasan al-Quran - Tafsir tematik atas pelbagai persoalan umat, second edition. Bandung: Mizan

UU 23 2004: Undang-undang Republik Indonesia nomor 23 Tahun 2004 tentang Penghapusan Kekerasan Dalam Rumah Tangga.

Yusuf, Milhan (2005): Hamka's method in interpreting legal verses of the Qur'an, in: Abdullah Saeed (ed.), Approaches to the Qur'an in contemporary Indonesia. Oxford: Oxford University Press, 41-66. 
, 


\title{
Debating gender, woman, and Islam: Indonesia's Marriage Law of 1974 revisited
}

\author{
Noorhaidi Hasan
}

\section{Introduction}

The relationship between gender, woman and Islam has long been debated in Muslim countries, including Indonesia. Questions are raised concerning the role played by religion and legal institutions in defining the male and female relationship and their rights and obligations when bound together in a marriage contract. Less than one year after her independence, Indonesia issued the Law No. 22 of 1946 requiring Muslims register their marriage, divorce and reconciliation. This law was issued to control arbitrary marriages and divorces among Muslims. After Suharto came to power as the replacement of Sukarno in 1966, more laws on Muslim personal status were enacted. In the early 1970s Suharto's government proposed a' marriage law requiring civil registration of marriages and court approval for divorce and polygamy. This bill was proposed as part of the state project of modernizing the practice of Islamic law within the framework of the Indonesian legal system - in response to an increasing awareness among Indonesian women of gender and their equal status with men before the law.

Since it had been perceived as Suharto's New Order project to control Muslim politics, the proposal set off a wave of protests from various spectrums of Muslim forces. They believed that this proposal would offend their religious beliefs, as it incorporated some notions contradicting to Islamic rules in favour of gender and human rights. In fact, the bill's tight regulation of polygamy was strongly opposed by 'ulam $\vec{a}$ ', who sought to maintain the practice. The same holds true for legal consequences of child adoption and for the allowance of inter-religious marriage. The issue of inter-religious marriages became highly charged politically mainly as a consequence of the interpretation of article 2(1-2) of the law, which says that "a marriage is legitimate if it has been performed according to the laws of respective religions and beliefs of the parties concerned"1.

The peak of the Muslims' protest was seen when the Indonesian Parliament discussed the bill. They staged a massive demonstration and occupied the parliament building. No less than 700 demonstrators were involved. In this situation, a lobbying

1 Cf. Noorhaidi Hasan 2011: 136-156. 
session was held between Muslim political groups represented by the United Development Party (PPP) and the government represented by the military faction in the parliament. $^{2}$ In this lobby, a compromise was reached by agreeing to the removal of some articles pertaining to the issues considered contradictory to Islamic principles. The revised draft was then passed by the parliament on 22 December 1973 and ratified as the Marriage Law No.1 of 1974.

The enactment of the Marriage Law of 1974 served as a catalyst of the dissemination of gender discourse and, although applying to all Indonesian regardless of their religions, of reactualization of Islamic law in Indonesia. Women empowerment and gender equality were considered to be an inherent part of both the Islamic teaching and the national strategy of development aimed at achieving prosperity and justice for all, or what is called mașlaḥa mursala in classical Islamic legal doctrine. During the 1980 s the discourse of reactualization of Islamic law resonated loudly and touched on such sensitive issues as inheritance. Munawir Sjadzali, the then Minister of Religious Affairs, proposed an equal proportion in inheritance between men and women, in contradiction to the 1:2 ratio of classical proportion of Islamic jurisprudence. ${ }^{3}$

In tandem with the mounting calls for gender equality, President Suharto issued the Presidential Instruction No. 1/1991 on the Compilation of Islamic Law in Indonesia (KHI), which was expected to strengthen the legal position of the marriage law, serving as the main and standardized reference for judges in religious courts when dealing with Muslim personal legal issues put before them. Compared to the Law of Marriage, the Kompilasi is more comprehensive as it regulates not only marriage and divorce but also inheritance. However, while the Kompilasi has a lower legal standing as it was issued under Presidential Instruction, the Law of Marriage has firm legal binding as it was issued as a law. Although, looking at its call or name, the Law of Marriage does not explicitly reflect the introduction of Islamic law on familial issues. However, when looking at its contents we could clearly see the incorporation of Islamic doctrines in it.

\section{Polygamy, divorce and marriage registration}

Under Islamic marital jurisprudence, a Muslim man is allowed to practice polygamy and he therefore can have more than one wife at the same time, up to a total of four. The Law of 1974 permits polygamy and but limits its practice. To limit it, the Law puts a number of conditions under which polygamous marriages are allowed. Permission for such a marriage has to be obtained from a religious court, and the permission will be based on the consent of the first wife of the petitioner (Art. 3[2]). The court verifies the reasons of why a husband proposes polygamy. The valid rea-

2 For a detailed account on this, see, i.e., Cammack 1996: 45-73 and Bowen 2003.

3 On this issue, see Saimina 1988; Ilyas 2006: 223-240; see also Feener 2007. 
sons include three conditions of the husband's existing wife, i.e., that she is unable to perform her duties, that she suffers from some physical defect or incurable disease, or she is unable to bear descendants (Art. 4). The law also stipulates that such a marriage can only be conducted if the husband is financially capable of maintaining co-wives and their descendants and if he is prepared to treat his co-wives equally (Art. 5).

Like polygamy, divorce is also restricted by the Marriage Law of 1974. The law basically allows divorce, but requires it be performed before court. For Muslims, this rule contradicts the classical Islamic marital doctrines which, as understood by Muslims, award husband a superior right and requires no intervention from other parties for exercising this exclusive right. The approval of a court is therefore not needed. The man can exercise his right without having to provide any reason. Before 1974 , the rule of divorce was much lighter for men as divorce could be unilaterally effective when a husband uttered the formula of divorce. He was only required to come to the office of religious affairs at a sub-district level (KUA) to register it. ${ }^{4} \mathrm{~A}$ husband remained to have superiority. Meanwhile, a Muslim woman had to appear before a judge and assure the judge that her husband had committed an act violating their marital agreement, called ta' $\operatorname{liq}_{q} \operatorname{tal} \bar{a} q$, in case her husband had refused to divorce her. After the ratification of the law, both a man wanting to repudiate his wife and a woman wishing to file for divorce, known as khul ', must appear before a judge and convince the judge about the availibility of one or more sanctioned reasons for divorce. While the rule of divorce remained the same for women, it became stricter for men. Both of them share the same grounds to be presented at court and to be verified by judges. Judges can order a husband to repeat the formula of divorce or grant his wife's request to have the marriage annulled, when they are convinced that a valid ground exists.

In tandem with its attempts to eliminate the practice of polygamy and arbitrary divorce, the Marriage Law of 1974 has a provision of marriage registration. As mentioned before, the article 2 (1) of the law stipulates that a marriage is legitimate if it has been performed according to the laws of respective religions and beliefs of the parties concerned. Both spouses must have the same religion in order to get married legally and they will experience two types of ceremonies. The religious ceremony will be performed first, followed by a civil ceremony, i.e., a registration of the marriage before officials of the local Office of Religious Affairs (Kantor Urusan Agama/KUA) for Muslims or of the Civil Registry Office for non-Muslims. The Office of Religious Affairs or Civil Registry will in turn issue a Marriage Certificate, which is evidence that the couple is legally married. ${ }^{5}$ Unregistered marriage of a couple is not considered to be a valid marriage according to the state. This lack of a legal status will affect the resolutions of divorce, division of marital properties, alimony, and child custody.

4 Bowen 2003. See also Nakamura 1983.

5 Ibid. 
It is of interest to note that the Supreme Court of Indonesia tried to overcome the difficulty of the registration of inter-religious marriage by issuing circular letters in 1975 and 1979 instructing the civil registry to conclude and certify inter-religious marriages. The status of interreligious marriages remains problematic, however, since the Ministries of Justice, Religion and the Interior issued a joint decision in 1987 allowing the Religious Affairs Office at the sub-district level only to certify Muslim births, marriages, divorces and deaths, thus implicitly denying the registry of inter-religious marriages. ${ }^{6}$

\section{Mounting calls for gender equality}

Introducing limitations on polygamy and divorce and requiring marriage registration, the Marriage Law of 1974 has debunked the traditional discourse and practice of Islamic law in Indonesia. Many progressive women in Indonesia have long felt injustice in Muslim legal practices pertaining to marriage and divorce. Their voices echoed louder and louder amid the rise of Muslim feminist movements actively voicing gender equality since the 1990s. In fact, several foundations concerned with gender and women issues were established in Yogyakarta in the 1990ss. These include Rifka Anisa and LSPAA (Institute for the Study of Women and Children). The former served as the first woman crisis centre calling for protection of woman rights in Indonesia and the latter focused on disseminating gender discourse and children's rights. In 1994, the Muslim woman organization affiliated to the largest traditionalist Muslim organization Nahdlatul Ulama (NU), Muslimah, in Jakarta set up a study group on women and Islam and published a book on the emancipation of women. In the same year, the Association of Pesantren and Community Development (P3M) launched a programme of fiqh al-nis $\vec{a}^{2}$ (Islamic Jurisprudence of Women). The program aims to strengthen the rights of women and their status in Islam through halaqa (training) and the publication of brochures, posters and books. ${ }^{7}$ The emergence of such NGOs inspired the cstablishment of women study centres (PSW) at Indonesian universities, the most prominent of which is the PSW of Sunan Kalijaga State Islamic University (UIN) of Yogyakarta established by Siti Ruhaini Dzuhayatin and her colleagues. Beside these, other centres including Kepak, Kapal Perempuan, have been established recently and shared the same notions with the centres established formerly and observed the rules on the gender issues.

The members of those centres were still unsatisfied with provisions in the law deemed to be in contradiction with the principles of gender equality and women's rights in Islam as well as universal norms. They questioned why in countries like

6 Hooker 2008: 14-15.

7 Ala'i Najib, 'Feminis Muslim Indonesia(Aliran Pemikiran Antara 1990-2000)', http://www.scribd.com/doc/41717386/feminisme. 
Indonesia where Islam is observed by the majority of its citizens gender equality remains a hindrance. Meanwhile, to their understanding, Islam has a clear idea of gender equality. In more explicit way, they therefore thought that polygamy is to be abolished and women are granted equal rights and obligations with men when bound in a marriage contract. They also called for more explicit legal protections for women as consequences arising out of their marital breakup. ${ }^{8}$ Such demands certainly invited fierce reaction from conservative Muslim groups who think the provisions of the law have already deviated too far from the norms of classical Islamic jurisprudence which give privilege to men in their marital relationships.

Despite these challenges, gender and women's right activists in Rahima, Fahmina, Puan Amal Hayati, and LBH APIK (legal aid centre for women), to mention but a few NGOs, have consistently struggled to improve women's legal status. They have addressed relevant issues both at the state level as well as at the grass-roots. ${ }^{9}$ They held seminars, workshops and trainings to disseminate gender equality and liberal interpretations of Islamic teaching in favour of women, involving a number of relevant groups including judges, marriage registry officials, and religious authorities. They also opened discussions with a number of female litigants to hear from them their experiences in resolving their familial cases from which the centres learned how their training has or has not affected the judicial discretion of judges that would benefit women. The Centre of Women Studies of State Islamic University, Yogyakarta, for an example, invited female litigants to share their experiences with them and asked them identify the judges that resolved their cases. By working to improve 'gender sensitivity' among their country fellows, they have contributed significantly to public debates and national policy on women. ${ }^{10}$ Collaborating with and funded by the Asia Foundation, the centre also organized trainings on the awakening of gender sensitivity among judges. A number of Islamic courts were involved in the trainings and the trainings have to some extent brought about the rise of gender awareness among judges as can be seen in their decisions. ${ }^{11}$

They had also made clear contributions to strengthen the notion of gender equality. Among their contributions that significantly influenced the discourse and debate on women was the so-called Counter Legal Draft of the Compilation of Islamic Law or Kompilasi Hukum Islam (CLD-KHI) proposed by a task force led by Siti Musdah Mulia, the chair of the gender mainstreaming committee in the Ministry of Religious Affairs of Indonesia. As slightly mentioned above, the Kompilasi Hukum Islam is a legal reference to be used, beside the Law of Marriage, by judges of the Islamic courts and therefore only applies to Muslims. Issued under the Presidential Instruction, the Kompilasi Hukum Islam consists of three books on marriage, inheritance and endowment and complements the legal references of judges for the issues of

\footnotetext{
8 See Nurlaelawati 2010.

9 White and Anshor 2008: 137-158.

10 Ibid. See also Salim et.al 2009: 23-40; Burhanuddin and Fathurrahman 2004: 113-152.

11 For further account on the trainings, see Salim et.al 2009: 23-60.
} 
inheritance and endowment arising within the Muslim Community. One of the points that the draft law emphasises is the idea of basic equal rights of human beings. This idea is framed within the maqāsid al-shari 'a or purposes of the sharia, which can be extracted into such basic principles as justice, equality and dignity. ${ }^{12}$

By looking to the maqāșid as an overarching inspiration in proposing the legal reform of the family, they called for husband and wife to be declared equal heads of family. They also mandated mutual obedience of spouses and adherence to the ideas of mutual obligations, duties and respect. In classical jurisprudence, the male can extract obedience from a wife for all sorts of things, and if she doesn't obey she is declared disobedient and can be reprimanded, including being physically admonished (nushüz). Another important feature of the LCD-KHI is that both women and men may marry non-Muslims. Because of these progressive provisions, the draft was seen too controversial ${ }^{13}$ and thus refused by Muslims from different spectrums, including the Indonesian Council of Ulama (MUI), to be submitted for national discussion. ${ }^{14}$

Feminists movements that have sprung up paid considerable attention not only to the Kompilasi Hukum Islam which, as noted above, applies only to Muslims, but also to the Marriage Law of 1974. As will become clear below, the Law of Marriage has become the object of legal attempts of reviews by some litigants. Some of its articles have also provoked feminists and activists to propose amendments.

\section{Judicial reviews on the Marriage Law: Cases of Machicha and Halimah}

The struggle by women's rights activists to improve gender sensitivity has brought about some significant changes in Indonesian women's awareness of their equal legal status and rights vis-a-vis men. In addition to the attempts by groups of feminists and activists to amend the laws, attempts had also been made by private persons. They did these by filing cases to higher courts when they felt they were treated unjustly by lower courts, requesting higher courts to revise the lower courts' rulings. Only few of them filed to the Constitutional Court (Mahkamah Konstitusi) established in 2003 to review rules of laws deemed to contradict or violate the constitution. In fact, even fewer popular women went a step further by applying judicial reviews on articles of the Marriage Law of 1974 to the Constitutional Court. ${ }^{15}$

Halimah, the ex-wife of Bambang Trihatmojo, the son of the former President Suharto, is one of these few women who applied judicial review to the Constitutional Court after she felt that she was treated unjustly. She asked the Court to

12 Nurlaelawati 2010: 125-130.

13 For the detailed points that are considered as controversial, see Yanggo 2005.

14 See Nurlaelawati 2010: 125-130. Cf. White and Anshor 2008: 146.

15 See Nurlaelawati 2013. 
review the article $39(2 \mathrm{f})$ of the law. This article regulates the procedures and grounds for divorce, stipulating that one of the grounds that a petition for divorce may be approved is a protracted or continuous dispute between spouses. Halimah argued that this provision is vague as it does not specify the conditions that result in continuous dispute. In other words, she questioned the type of dispute that the judges might consider to be valid grounds for divorce. ${ }^{16}$ She admitted that she had several disputes and arguments with her husband, but insisted that the source of the dispute was the fact that Trihatmojo, her husband, had married a famous singer, Mayangsari. ${ }^{17}$ Proposing this article be reviewed, she did not mean to argue against the article. However, since the article has been strictly interpreted by judges she demanded the article be eliminated.

Unfortunately, although she obtained considerable support from various parties, including some scholars and activists such as Sinta Nuriyah Wahid, Siti Musdah Mulia and Bismar Siregar, she could not assure the judges to annul the article. In fact, after several hearings and discussions, the Court rejected her petition, arguing that the article in question was, in principle, issued to legally protect human rights and specifically rights of women within marriage. Mahfud MD., the chairman of the Court argued that the article should be maintained to provide a legal recourse for a couple which, due to continuous disputes, could not realize the sacred purpose of marriage. ${ }^{18}$ He seemed to be very consistent with the notion of 'broken marriage', which, according to Bustanul Arifin, is the condition that could be highly considered regardless of the parties that initiate or generate the situation. ${ }^{19}$

Halimah was not the only woman who took this step. In fact, a similar endeavour to review provisions in the Marriage Law of 1974 was also taken by a quite famous Dangdut singer, i.e., Machicha Muchtar. Machicha was the ex-unofficial wife of Murdiono, former State Secretary of Indonesia. For a long time Machicha had been unable to obtain a legal status for her son in relation to Murdiono, his biological father. This case began when in 1993 Machica was unofficially married to Murdiono and few years after bore him a baby, named Muhammad Iqbal Ramadhan. At the time, Murdiono was tied with a valid marriage with his first wife. Having married informally, Machicha was not considered a legitimate spouse and had difficulties obtaining legal documents for her son, including a certificate of birth. Worse still, later Murdiono divorced Machicha according to Islamic law and did not recognize Iqbal as his son nor paid financial support for him. In order to solve these problems, Machicha turned to a religious court in 2008 to ask for isbat nikah (a legal and official confirmation of her marriage) and for legalization of the status of her son. She

16 'Halimah Kamil files judicial review', The Jakarta Post, July 11, 2011, accessed in 5 May 2013.

17 'Halimah Agustina Kamil gave evidence in judicial review of Act of Marriage', www.mahkamahkonstitusi, go.id, 21 July 2011, accessed in 14 April 2013.

18 'Gugatan ditolak MK, Halimah tak akan rujuk', Kapanlagi.com, March 27, 2012, accessed in 12 August 2012.

19 See Ahmad et.al 1996. 
was unable to prove her marriage contract with Murdiono, since the latter refused to show up. Hence, she failed to obtain the certificate of marriage confirmation and to obtain a formal recognition of her child's legal relationship with his biological father. ${ }^{20}$ The court can only provide an isbat nikah if both parties agree, on their own free will, that they have concluded an Islamic marriage and if they have no dispute over the issue.

Having failed to win the case, Machicha filed a petition to the Constitutional Court on article 43 of the Marriage Law of 1974 that according to her interpretation was the source of the problems she was facing. The article stipulates that children born out of wedlock only have a legal relationship with their mothers and their mother's relatives ${ }^{21}$, and it has prevented her from obtain the legal confirmation of her marriage with Murdiono and of the legal paternity of their son. Like Halimah, Machicha gained considerable supports from women activists and with the support of a number of legal scholars concerned with the protection of women and children rights she was confident that she won it. After several discussions and hearings and although one female judge objected to meet the petition, the Court decided to approve it and to amend the article. As a result, the rule that children born out of wedlock have a legal relationship to only their mothers and their relatives was amended to the effect that children born out of wedlock have also a legal relationship with their biological fathers if medical technology can convincingly prove their biological paternity. ${ }^{22}$ The Court held that it is not fair and proper to pronounce or decree that children born out of wedlock have a legal private relationship with only their mothers and thus to free men, who have had sexual intercourse that resulted in pregnancy, from financial or custodial responsibilities to their children.

The decision was celebrated by a number of groups such as the institution of the legal aid and the National Commission of Children Protection (Komisi Nasional Perlindungan Anak). The National Commission of Children Protection highly appreciated the Constitutional Court's decision and considered it as a good solution to one of the biggest problems that it regularly has to deal with. It is not an exaggeration if the Commission welcomed the decision with its excitement, as since its establishment it has been consulted by hundreds of mothers that felt injustice of the matter. The chairman of the commission, Arist Merdeka Sirait, informed that in 2011, there were 38 cases on the legal status of children born out of wedlock brought to the commission, in which the private rights and custodial right of the children involved were questioned. He stated that the amendment of the article would decrease such cases and hoped that those cases could now be solved and children would get their basic rights. ${ }^{23}$

20 See Nurlaelawati 2013: 68.

21 See article 4 of the Marraige Law of 1974.

22 'MK sahkan status anak di luar nikah resmi', Kompas, 19 February 2012, accessed on 1 April 2013.

23 'MK sahkan anak lahir di luar nikah resmi', Kompas, 19 February 2012, accessed on 1 April 2013. 
Some groups however saw the decision with different thought and considered it as having deviated from the classical Islamic legal doctrines. Reactions and criticism arose among Muslim scholars. The MUI, for instance, opposed the decision and reckoned it is to legalize informal (unregistered) marriage and adultery. They also questioned the substance of the decision which to them went beyond what was actually being appealed by the petitioner. They recalled that the petitioner questioned only the legal status of the petitioner's child born out of her unregistered (Islamic) marriage, and therefore the Court was not to deal with broader issues, that would include the legal status of children born out of wedlock. ${ }^{24}$ They reminded the MK of having to be very careful and assertive about the ruling.

Having felt that the discursive reaction had been not enough to articulate their thinking that the decision by the Court violates Islamic legal doctrine, the MUI decided to issue a fatwa on the rights of children born out of wedlock. The fatwa offered the basic references of the Qur'an, Hadith, and fiqh doctrines and affirms the absence of legal relationship of children with their biological fathers. Nevertheless, although it affirms the established rule, it introduced a new interpretation to accommodate children interests. In detail, the fatwa asserts that children born out of wedlock have a legal relationship with only their mothers. They therefore do not have a legal relationship to their biological fathers, do not inherit from, and would not be financially supported by their biological fathers. It also states that children born out of wedlock are not to bear the sin of the adultery committed by their parents and requires the adulterer be sentenced to hadd (stoning) to keep legal genealogy. As to protect the children' rights, it urges the government to force male adulterers to provide proper financial support for their children, to award property or estate through wasizya wäjiba (obligatory bequest) after their death. In the end, it avows that the sanction specified above is not intended to legalize relationship between children and their biological fathers, but merely to protect the rights of children. ${ }^{25}$

\section{Proposal for amendment of the Marriage Law of 1974}

In response to recurrent problems arising from ambiguous positions of the Marriage Law of 1974 on women and children and mounting demands for protection of women and children's rights, women rights activists affiliated to LBH-APIK called for an amendment of several provisions in the law. ${ }^{26}$ On the basis of the principle of non-discrimination, protection of human rights and gender equality, they demanded rules on the registration of marriages be amended so that all Indonesian citizens are treated equally without any distinction based on religion. Therefore, according to

24 'Keputusan MK kebablasan', Kompas, 9 April 2012, accessed on 5 April 2013.

25 See Fatwa MUI No. 11/2012.

26 LBH-APIK, 'Pokok-pokok pikiran usulan amandemen UU Perkawinan', at http://www.lbhapik.or.id/amandemen_uu_pokok2_pikiran.htm, accessed on 20 May 2013. 
them, article 2 (2) instructing that "every marriage is to be recorded in accordance with the existing legal rules" is to be amended. They propose it to read that 'every marriage must be recorded in certain registry units of the Ministry of Religious Affairs in accordance with the religion of respective parties in question'. The reason for this change is that article 2 (1) stipulates that every marriage is contingent on respective parties' religion, then the proper registration of marriages is arranged and conducted by different religious units that exist under the auspices of the Ministry of Religious Affairs.

Polygamy also became the object of their projects of amendment. They demanded the abolition of Articles 3, 4 and 5 of the Marriage Law of 1974 based on a reason that polygamy is an act that clearly subordinates and discriminates women. These articles are deemed contradictory to the principles of gender equality, antidiscrimination and anti-violence adopted by the Indonesian Constitution, which is in line with the principles adopted in international norms, especially the Universal Declaration of Human Rights (UDHR) and Covenant on Elimination against All Forms of Discrimination against Women (CEDAW). Polygamy is even considered to be one of the factors behind domestic problems experienced by women and children, who have suffered from physical, psychological, sexual and economic violence. Polygamy itself is believed to be a domestic violence legitimized by law and belief systems that exist in society. ${ }^{27}$

Demands for change are also addressed concerning the articles 7 and 11 of the Marriage Law of 1974. Article 7 stipulates that marriage is only permitted if a bridegroom has reached the age of 19 years (nineteen) years and a bride has reached the age of 16 (sixteen) years. According to the framers of the draft amendment, marriage is allowed if both parties are over the age of 18 (eighteen) years. The age distinction between men and women is believed to imply a gender bias subordinating women. The age of 18 years as that of maturity is proposed in reference to the law of child protection that administers that a person is considered as a child before he or she reaches at the age of 18. Meanwhile, article 11 stipulates that when a marriage dissolves women are subject to 'idda, i.e., a period of waiting of 3 months for those not menstruating, of three times of being clean for those menstruating and of 4 months for those whose husbands die, during which they may not marry another man. Derived from the classical Islamic jurisprudence this rule is considered to be discriminative against women and, therefore, requires removal. In the draft amendment, the period of waiting is imposed for both parties and this is considered more appropriate because it ensures an equal treatment between men and women. $^{28}$

27 LBH-APIK, 'Usulan amandemen UU Perkawinan No. 1/1974 berikut argumen-argumennya', at http://www.lbh-apik.or.id/amandemen_UUP-usulan.htm, accessed on 20 May 2013. See also Amrie Hakim, 'Poligami masalăh krusial dalam revisi UU Perkawinan', at http://www.hukumonline.com/berita/baca/ho19232/poligami-masalah-krusial-dalam-revisiundangundang-perkawinan.

28 LBH-Apik, 'Usulan UU Perkawinan No.1/1974 berikut argumen-argumennya', at 
More significant change is proposed to articles 31 and 34 of the Marriage Law of 1974 on the rights and status of husband and wife deemed to be discriminatory against women. The draft amendment requires that the rights and position of a wife is equal to those of her husband in both domestic and public spheres. Each party has the same right to take legal actions in public sphere and bear the same role and responsibility in their households. Article 34 of the law stipulates that a husband is obligated to protect his wife and bear all spousal alimony arrangements (nafka) in accordance with his ability, while a wife is responsible for managing domestic affairs of their household. This article is deemed responsible for the standardization of a stereotypical role division between men and women. Men are placed as the superior responsible for social and economic affairs for his family while women only have to deal with domestic affairs. Such a role division is one factor behind the impoverishment of women: making one party (the wife) economically dependent on the other party (the husband). In many cases of domestic violence, the victim (women) can not easily get out of the environment of violence as a result of economic dependency. While the ex-husband is required to pay alimony to his ex-wife, this provision has never been effective in forcing the ex-husband to pay the alimony and this remains contingent on the willingness of the ex-husband.

Attention is also given to article 43 of the Marriage Law of 1974 on children. This article stipulates that a child born out of wedlock has only a civil and legal relationship with his mother, as mentioned before. The draft amendment proposed that such a child has a civil and legal relationship with both his/her biological father and mother and family and it can lay claim at Court to obtain a recognition from the biological father through his/her biological mother. They also proposed that a child born as a result of an in vitro fertilization programme undertaken by a legitimate couple is the legitimate child of the couple and that the baby whose seeds deposited on the tube of another woman is a legitimate child of the couple. The main reason put forward by the framers of the draft amendment is that all children are entitled to gain recognition and protection of both father and mother in accordance with article 7 (1) of the Law No. 23 of 2002 on children protection. Another reason for this is the article 16 of CEDAW - by which Indonesia abides - that requires that a couple has the same rights and responsibilities in all matters relating to marriage, including guardianship, maintenance, supervision and adoption.

The National Commission for Women (Komnas Perempuan), which was born as a reform result in 1998, supported the effort made by women's rights activists to amend the Marriage Law 1974. In a seminar on 22 September 2011, for instance, this commission highlighted the urgency of the amendment of the law. The main argument put forward by Komnas Perempuan is that so many marriages have caused misery for women as a result of the vagueness of the articles in the law. In 2009 alone, for example, the agency received as much as 49 complaint cases related to unregistered marriages. Registration of marriage is believed to be a guarantee for a

http://www.lbh-apik.or.id/amandemen_UUP-usulan.htm, accessed on 20 May 2013. 
legal status and right of women when bound together in a marriage contract. Unregistered marriage is deemed to be one of the most focal causes behind the spread of polygamy. It is also believed to be the main factor behind the high rate of domestic violence that reached 143,586 registered cases in $2009 .{ }^{29}$

As in the case of Kompilasi Hukum Islam, the draft amendment of the marriage law spurred criticism from various spectrums of conservative Muslims. Hard-liners in the Hizb al-Tahrir Indonesia (HTI), for instance, assumed that the framework of the amendment cannot be dissociated with the ambition of liberal Muslim activists to undermine Islam and the Muslim Umma in Indonesia. This is considered to be their second step to achieve their goals after their failure in proposing the Counter Legal Draft of the Compilation of Islamic Law (CLD-KHI). In their opinion, the CLD-KHI openly attacked Islam, and therefore the draft amendment of the marriage law - as a continuation of the CLD-KHI - should be confronted at all costs as well. According to HTI, the reason to refuse the draft amendment is that the liberal activists standing behind it lost no courage to realize their dream of secularizing the country: They have attempted to infuse their liberal thoughts as reflected in the CLD-KHI into various legal products, including the Law on the Elimination of Domestic Violence (UU KDRT) and the Law on Children Protection (UU Perlindungan Anak). ${ }^{30}$ Both laws are deemed to have deviated too far from Islam. HTI believes that the women's rights activists behind the laws are Zionist collaborators who also tried to legalize mixed marriages through the enactment of the citizenship law. ${ }^{31}$

HTI alleged that the initiators of the draft amendment were not satisfied with what they have achieved so far and went a step further by proposing the amendment aiming at annuling polygamy granted by the Qur'an. Their arguments associating polygamy with domestic violence are considered implausible since polygamy is believed to be an important mechanism to meet women's need for protection. In addition to these, HTI pinpointed that other provisions proposed in the draft amendment have also deviated too far from the sharia, including article 7 that reads "Marriage is permitted if a bridegroom has reached the age of 19 years and a bride has reached the age of 16 years" is to be replaced with "marriage is only allowed if both parties are over the age of 18 years". In addition to the above article, HTI also questioned the provision on the period of waiting for divorced women. ${ }^{32}$

29 Http://www.komnasperempuan.or.id/wp-content/uploads/2011/09/Kertas-Konsep-PerubahanAtas-Undang-Undang-Nomor-1-Tahun-1974-Tentang-Perkawinan-Disampaikan-KunthiTridewiyanti-Komnas-Perempuan.pdf.

30 Kholda Naahiyah, 'Penghancuran keluarga melalui Amandemen Hukum Perkawinan', at http://hizbut-tahrir.or.id/2007/06/26/m accessed in 20 May 2013.

31 See 'UU Perkawinan (Mewaspadai kritik kaum liberal)', at http://hizbut-tahrir.or.id/ 2011/10/28/uu-perkawinan-mewaspadai-kritik-kaum-liberal/.

32 Ibid. 


\section{Conclusion}

The discussions above demonstrate that questions about the legal status and rights of women in Indonesia are not fully settled yet. Pros and cons are still working between those aspiring for fundamental changes in various regulations concerning the personal status of women vis-a-vis men, especially the Marriage Law of 1974, and those wanting to maintain the status quo. For the latter, the law is even too progressive and its many provisions contradict the provisions in classical Muslim jurisprudence. Even though the end of this debate cannot be predicted, these procons clearly show the dynamics of gender discourse, Islam, and legal thought in Indonesia.

The dynamics are not only clear among gender activists, but also within female litigants, particularly those who have the chance to be close to elite people. With the support of feminists and gender activists, few female litigants not only filed their cases to higher courts when they felt that the applied laws have not benefited them or when justice had not been achieved to overrule the rulings issued by lower courts. They also proposed judicial reviews to a recently established court, the Constitutional Court, on the applied laws. Although the petitions have not always been approved, the attempts of these few female litigants have demonstrated that women remained unhappy with the Law of Marriage and that the Law of Marriage remains worth revisiting. The actors of the reform of family law and the participants of the debate of the notion of gender and Islam therefore include not only state, 'ulama ', and legal scholars, but also women in person or in institutions.

\section{References}

Bowen, John (2003): Islam, law and equality in Indonesia: An anthropology of public reasoning. Cambridge: Cambridge University Press.

Burhanuddin and Fathurrahman (2004): Tentang perempuan Islam: wacana dan gerakan. Jakarta: Gramedia Pustaka/ PPIM.

Cammack, Mark et al. (1996): Legislating social change in an Islamic society: Indonesia's Marriage Law, in: American Journal of Comparative Law 4-1, 45-73.

Feener, R. Michael (2007): Muslim legal thought in modern Indonesia. Cambridge: Cambridge University Press.

Rauf Saimina, Iqbal (ed.) (1988): Polemik reaktualisasi ajaran Islam. Jakarta: Pustaka Panjimas.

Hisako, Nakamura (1983): Divorce in Java. Yogyakarta: Gadjah Mada University Press.

Hooker, M.B. (2008): Indonesian Syariah, defining a national school of Islamic Law. Singapore : ISEAS.

Ilyas, Yunahar (2006) : Reaktualisasi ajaran Islam: studi atas pemikiran hukum Munawir Sjadzali, in: Al-Jami' ah Journal of Islamic Studies 44-1.

Noorhaidi Hasan (2011): Political Islam in Indonesia, in: Ishtiaq Ahmed (ed.), The politics of religion in South and Southeast Asia. London and New York: Routledge, 136-156. 
Nurlaelawati, Euis (2010): Modernization, tradition and identity: The Kompilasi Hukum Islam and legal practice in the Indonesian Religious Courts. Amsterdam: Amsterdam University Press.

- (2013): Sharia-based laws in Indonesia: position of women in legal practices, in: Regime change, democracy and Islam: the case of Indonesia. Final Report Islam Research Programme Jakarta, Leiden.

Salim, Arskal; Wahdi Sayuti; Euis Nurlaelawati \& Lies Marcos (2009): Demi keadilan dan kesetaraan, sebuah dokumen program sensitivitas jender hakim agama. Jakarta: Puskumham UIN Syarif Hidayatullah and the Asia Foundation.

White, Sally and Maria Ulfah Anshor (2008): Islam and gender in contemporary Indonesia: public discourses on duties, rights and morality, in: Greg Fealy \& Sally White (eds.), Expressing Islam: religious life and politics in Indonesia. Singapore: ISEAS, 137-158.

Yanggo, Huzaemah Tahido (2005): Kontroversi revisi Kompilasi Hukum Islam. Jakarta: Adelina. 


\title{
Apostasy as grounds in divorce cases and child custody disputes in Indonesia
}

\author{
Muhrisun Afandi
}

This paper focuses on the extent to which religious conversion provides grounds in divorce and child custody disputes in Indonesia, especially within Muslim communities. This study is part of a comprehensive research project on child welfare policies in Indonesia, involving a series of interviews conducted with three groups of participants: Muslim leaders and judges, government officials, and professionals. Issues related to religious conversion per se were not among the principal initial emphases of the larger study and it was quite unexpected that the subject emerged as a major finding of this study, as reflected in the insights and perspectives of the participants, especially religious judges, based on their current experience working with Muslim communities.

It will become evident from this study that apostasy or adherence to a different religion is regarded as valid grounds by most religious judges in divorce cases. Apostasy also provides grounds in cases of child custody disputes. The finding of this study shows that most religious judges base their verdict on religious allegiance rather than the best interests of the child, as most of them will automatically grant custody to the Muslim parent (father or mother) regardless of his or her capacity to provide appropriate parenting for the child. It appears, for example, that an accusation of apostasy can result in a good mother losing custody of her infant; custody very likely will be granted to the Muslim father even though he is proven to be abusive or incapable as a parent. This might place the child at risk.

\section{A. Introduction}

Religious conversion is a serious issue in Islam as it has grave implications for the person involved in respect to some important aspects of his or her life, such as parental relationships, inheritance, the validity of marriage, and child custody rights. The complex issues of apostasy in Islamic jurisprudence, moreover, show that some serious infringements of religious freedom, and human rights in general, potentially occur in the application of Muslim legal traditions ${ }^{1}$.

1 Bielefeldt 2000. 
Apostasy in Islam, known in Arabic as irtidād or ridda ${ }^{2}$, is commonly defined as 'turning away from Islam' or 'severing the ties with Islam'. ${ }^{3}$ There are various synonymous terms commonly used to amplify the scope and definition of apostasy, such as blasphemy, heresy, hypocrisy and unbelief. ${ }^{4}$ These terms might not convey the same meaning as apostasy, yet they appear to be used interchangeably in literature, while in Islamic jurisprudence, as further noted by Saeed \& Saeed ${ }^{5}$, the notion of ridda combines these different terms.

The term apostate (murtad) refers to a Muslim who abandons or renounces his or her religion, whether a person converts to another religion or merely wishes to give up Islam and become an atheist. ${ }^{6}$ However, it seems that the legal implications of apostasy are applied especially to those who convert to another religion. This is among the reasons why in most cases the definition is often simplified into 'becoming an infidel' which automatically disentitles the person involved to his or her status and rights as a Muslim.

As is also evident in the texts of the other two Abrahamic religions, Judaism and Christianity, apostasy is regarded in Islamic texts as a punishable crime against Islam. ${ }^{7}$ Referring to various classical tenets of Islamic jurisprudence on ridda, some Muslims argue that the blood of a person who converts from Islam is halāl (permissible), implying that he or she should be killed. ${ }^{8}$ While apostasy is strongly condemned in some verses of the Quran, controversy arises in some Muslim countries with respect to the penalty that should be applied to apostasy. In fact, there is no clear punishment prescribed for apostasy in the Quran. ${ }^{9}$ Among the provisions commonly used to justify harsh penalties is the Hadith "man baddala dinahu faqtulühu" (whoever changes his religion, kill him). Thus in some Muslim countries conversion is legally punishable by death, but the validity of the Hadith has been debated among scholars. Rehman ${ }^{10}$, for example, argues that the fact that Muhammad did not appear to implement the sentence himself raises questions about the validity of this provision.

It is commonly argued that the concept of religious freedom is, in fact, emphasized in the Quran (2: 256), in which it is clearly stated that "lä ikrāha fi al-dīn" (There shall be no compulsion in [acceptancc of] the religion). However, it cannot be denied that some other verses, especially those condemning conversion and its related punishments ${ }^{11}$, stipulate that freedom of religion does not exist in Islam.

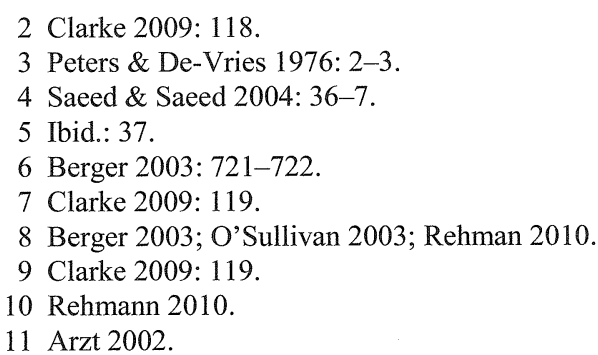


Even for individuals above the age of 18 , being entitled to rights as a capable individual does not necessarily mean that they are also entitled to choose his/her own religion. The discourse of religious freedom, on the contrary, is often misinterpreted by some Muslims as giving legitimacy to apostasy. In Middle Eastern communities, as noted by Rajabi-Ardeshiri ${ }^{12}$, the issue of religious freedom and apostasy has also been successfully used by the authorities as a political tool for suppressing people's rights to freedom of expression.

In the context of Indonesia, as is also the case in such Muslim countries as Malaysia ${ }^{13}$ and Egypt ${ }^{14}$, 'apostasy usually becomes a legal issue only with regard to its consequences ${ }^{15}$, particularly in terms of personal status. There are no reports that capital punishment for conversion has been carried out in Indonesia, but the fact remains that Islamic practices in Indonesia stipulate legal consequences for those who are involved which affect, for example, their marital status and their child custody rights, which are discussed in this paper.

\section{B. Overview of the study}

This paper is drawn from a comprehensive research project on child welfare policies in Indonesia, as part of a $\mathrm{PhD}$ project undertaken at Monash University (Melbourne, Australia). Issues related to religious conversion in particular were not among the principal initial emphases of the larger study. However, the subject emerged as an important finding of this study, as reflected in the insights and perspectives of the participants based on their current experience working with Muslim communities.

A qualitative approach was employed in this research, using a series of interviews conducted with three groups of participants: Muslim leaders and religious judges, government officials, and professionals. For the purpose of this paper, however, discussion focuses on the interviews conducted with four participants from the group of Muslim leaders and religious judges relating to the extent to which religious conversion provides grounds in divorce and child custody disputes in Indonesia, especially within Muslim communities. Two participants were recruited from religious courts in Yogyakarta, while the other two judges work at religious courts in Central Java and West Java. For confidentiality reasons, the participants are referred to as $\mathrm{P} 1, \mathrm{P} 2, \mathrm{P} 3$, and $\mathrm{P} 4$.

The interviews were conducted in Indonesian but expressions from such other languages as Arabic, Javanese and other local languages were also involved. The English translation of the transcripts adheres as closely as possible to the original Indonesian versions. In this case, some structural and grammatical errors in the tran-

12 Rajabi-Ardeshiri 2009.

13 Kirby 2008.

14 Berger 2003; O'Sullivan 2003; Johansen 2003.

15 Berger 2003: 725. 
scripts, such as missing subjects, verbs, or objects in some sentences are left as they are in the Indonesian versions. ${ }^{16}$

\section{Interreligious marriage and apostasy issues}

Interreligious marriage is not recognized in the Indonesian Marriage Law (Law No.1/1974). Indeed, this was underlined by the government in 1991 through a presidential instruction (No.1/1991) on the Indonesia compendium of Islamic law, known as KHI (Kompilasi Hukum Islam). Articles 40 and 44 of this compendium emphasize that it is forbidden for Muslims, men and women, to marry non-Muslims. In line with the provisions of the marriage law and the compendium, the Indonesian Council of Ulama (Majlis Ulama Indonesia) has also issued verdicts in 1980 and 2005 emphasizing that interreligious marriage is forbidden.

The compendium itself, which is regarded as a modern version of Islamic law in Indonesia, was intended to be a reformed version of Indonesian Islamic law developed in response to disputes over interpretations of Islamic law among religious judges in a number of Indonesian provinces. ${ }^{17}$ It provides codes to guide Indonesian Islamic courts on such issues as marriage, inheritance, and endowment. A number of human rights activists criticized some articles of the compendium related to interreligious marriage and some other issues as being more conservative than the existing marriage law.

In fact, there are disputes among Muslim jurists and scholars with respect to the extent to which interreligious marriage is forbidden in Islam. ${ }^{18}$ As noted by Ghaz$\mathrm{ali}^{19}$, there are three major perspectives of 'ulama $\bar{a}$ ' on the matter of interreligious marriage. The first perspective holds that interreligious marriage is forbidden totally for Muslim men and women, without exception. This opinion is based on provisions of the Quran, especially al-Baqara [2]: 221, al-Mumtahana [60]: 10, and al-Mà'ida [5]: 5. Furthermore, 'ulam $\bar{a}$ ' who share this perspective make reference to the response given by Umar ibn Khattab to these Quranic provisions. Narratives relate that Umar ibn Khattab, one of the caliphs, decided to divorce his two wives who were non-Muslims, Binti Abi Umayyah ibn Mughirah and Ummu Kulthum binti Amr ibn Jarwal, following the revelation of al-Mă ida [5]: $5 .^{20}$ The decision made by Umar

16 In order to make the quoted transcripts more understandable, parentheses '( )' and square brackets '[ ]' are used to enclose explanatory and missing materials. Parentheses are used to include translations or explanations of specific terms, additional information, and clarification, while square brackets are used to enclose missing material in the quoted transcript, such as missing subject, verb, or object. The square brackets are especially intended to indicate modifications that have been made to the original text for grammatical purposes.

17 Hallaq, 2009; Butt, 2010.

18 Eid 2005: 46-7.

19 Ghazali 2012.

20 Ibid.; see also Mawdoodi 1983:12. 
ibn Khattab is considered as a strong reference for the position that interreligious marriage is strongly forbidden in Islam.

The second perspective believes that interreligious marriage is recognized in Islam when a Muslim man marries a non-Muslim from ahl al-kitāb (people of the book), referring to Jewish and Christian women who believe in God and a divine scripture. ${ }^{21}$ This perspective refers to $a l-M \bar{a}^{3} i d a$ [5]: 5, 6, which stipulates that such an exception is permitted in Islam with respect to interreligious marriage. 'Ulama' from this second perspective believe that al-Má ida [5]: 5, which was revealed later than the two other verses (al-Baqara [2]: 221, al-Mumtahana [60]: 10), was meant to expand on or amend the total prohibition of interreligious marriage. ${ }^{22}$

Those expressing the third perspective believe that the exception mentioned in al-Mâ'ida [5]: 5 is not merely for Muslim men but also for women who are allowed to marry a non-Muslim, especially ahl al-kitāb. This perspective refers to the marriage of the two daughters of Muhammad, Zainab and Ruqayyah. Zainab was married to Abū al-'Ạs while Ruqayya was married to 'Utba ibn Ab̄̄ Lahab. Both marriages took place before the development of Islamic law. The fact that Muhammad himself did not require his daughters to renew their marriage following the introduction of Islamic marriage law is used by some scholars to justify the position that interreligious marriage is not prohibited even for Muslim women. ${ }^{23}$

Among these three perspectives it appears that the second view, that the only form of interfaith marriage recognized in Islam is that of a Muslim man to a woman from ahl al-kitāb, is the most widely held opinion among Muslims. ${ }^{24}$ However, most Muslim jurists highlight the importance of maintaining a distinction between the permissibility of interreligious marriage with its advisability. Even though some jurists believe that such a marriage is lawful, most emphasize that interreligious marriage is not advisable in Islam. Among the common reasons for discouraging interreligious marriage is the religion of the children. Jurists are concerned that, in the case of divorce, children from an interreligious marriage will be at risk of being brought up in a religious tradition other than Islam. ${ }^{25}$

The provision that Muslim men can marry non-Muslims while the women may marry only Muslim men is considered gender biased and unfair to women. The claim of some scholars, such as Mawdoodi ${ }^{26}$, that when a Muslim woman marries a non-Muslim man it will be virtually a certainty that she will be disconnected from Islamic traditions, while her children will almost certainly be raised in a non-Islamic tradition, might be irrelevant in the contemporary context of Muslim society in Indonesia. The concept that the husband is the head of the family who has virtually total authority over his wife has changed in the context of contemporary Indonesian

21 Eid 2005: 46.

22 Ghazali 2012.

23 Ibid.

24 Eid 2005: 46; Aini 2008.

25 Eid 2005: 53.

26 Mawdoodi 1983. 
communities. The debate over the authority of husbands is more serious in communities where Muslims form a minority group, such as in the United States. As noted by Eid, 'Muslim women are more likely to have difficulty in finding a suitable husband since allowing the men to intermarry will reduce the number of available Muslim men'. 27

The argument that intermarriage is allowed only for Muslim men and not for Muslim women in order to ensure that children will not fall into the custody of nonMuslim parents might be seen to be appropriate only in the context of patriarchal Muslim societies in which the father is considered the sole religious guardian of the children. However, this argument has less validity in the context of Western societies. In the case of Muslim communities in the United States, as noted by Eid $^{28}$, fathers cannot always claim to be the sole religious guardian of their children since, in divorce cases, civil courts will most likely grant the child custody to mothers. This means that allowing Muslim men to marry non-Muslim women can have the result of allowing children to be brought up by non-Muslim mothers, which is contrary to the position of most Islamic jurists.

\section{Children's Freedom of Religion}

The Convention on the Rights of the Child (hereafter CRC) is the first legally binding international regulation "that includes an explicit reference to Islamic law"29. The fact that the CRC has been overwhelmingly ratified by Muslim countries, in which all states that are parties under the Organization of Islamic Cooperation (hereinafter $\mathrm{OIC}^{30}$ ), including Indonesia, have positively responded to the convention $^{31}$ is considered as a positive step towards the development of adequate child welfare systems in Muslim societies. The support of the OIC for the implementation of the CRC in Muslim societies was further underscored by the development of the Covenant on the Rights of the Child in Islam ${ }^{32}$ which was officially adopted by member states of the OIC in 2005 at the summit of their foreign ministers in 2005.

With regard to children's freedom of religion in the context of Indonesia, in addition to Article 14 of the CRC concerning children's right to freedom of thought and conscience and freedom of religion, Article 18 (2) of the International Covenant

27 Eid 2005: 48.

28 Ibid.

29 Hashemi 2007: 196.

30 The Organization of Islamic Cooperation (OIC), formerly referred to as the Organization of the Islamic Conference (OIC) founded in 1971, is the largest world organisation of Muslim countries. To date OIC has a membership of 57 states and other states as observers. The Organisation is considered to be relatively unstructured, as the principal institution of the OIC is the conference of foreign ministers (Shaikh 1992; Haynes 2001; Marshall 2010).

31 Syed 1998: 359 .

32 Mosaffa 2011. 
on Civil and Political Rights (hereafter ICCPR), which was ratified by Indonesia in 2005 by Law No.12/2005, also applies. This article of the ICCPR asserts that no one shall be subjected to coercion that would impair his or her freedom to have or to adopt a religion or belief of his or her choice.

The Indonesian Child Protection Law (No.23/2002), Article 42 [1], further emphases the freedom of children to express and perform their chosen religion. At the same time, however, Article 42 [2] of the law implies that a child's religion is the religion of the child's parents, implying in turn that children's freedom of religion does not really exist. The law also does not address directly the issue of interreligious marriage; there is no clear provision with regard to who should be the religious guardian of the child, the father or the mother.

The implementation of the provisions bearing on children's freedom of religion has been problematic. There appears to be a common belief that protecting children in the path of Islam is ultimately an obligation not only for the parents but also for the Muslim community in general. This is among the reasons why controversies arise among Muslims in Indonesia in response to government policies concerning such issues as adoption, guardianship, and foster parenting. Controversies occur concerning the freedom of religion of adopted children and those under the care of non-Islamic institutions and orphanages, based on the fact that parents and institutions from different cultural and religious backgrounds might adopt or take care of a Muslim child. In fact, religious issues surrounding adoption and foster parenting were among the issues that were discussed intensively during the debate of the enactment of the Indonesian Child Protection Law (No.23/2002), when differing perspectives on cultures and religious issues were expressed by members of the legislative assembly.

It is asserted by Langlaude ${ }^{33}$, referring to 'will theory', that recognition of children's rights entails "powers of enforcement and waiver that the child does not always have" ${ }^{\prime 34}$. Therefore, the concept of granting or recognizing freedom for children to choose their religion or to make their own religious judgments is even more difficult in such religious communities as in Indonesia. The concept that children enjoy rights as independent individuals is not well accepted in society. This appears to be among the principal reasons why fully implementing such legally binding international regulations concerning children's freedom of religion as the CRC has been problematic in Muslim countries ${ }^{35}$, regardless of the fact that the CRC, as noted above, has been overwhelmingly ratified by Muslim countries, including Indonesia.

Reservations made by some Muslim countries, including Indonesia, to Article 14 of the CRC concerning children's right to freedom of thought and conscience and freedom of religion has exacerbated the difficulties that some Muslim countries face in incorporating principles related to the best interests of the child in their existing

33 Langlaude 2008.

34 Ibid.: 478.

35 Langlaude 2007: 2008. 
regulations. As noted by Syed, it is of serious concern that Muslim countries, by adopting the approach of 'declaration and reservation"36, are formally addressing only a few fundamental issues regarding children's rights addressed by the Convention. They are not necessarily interested in fully incorporating the Convention into domestic legislation. As noted by McLean ${ }^{37}$, such collective reservations clearly show that the religious dimension might pose a serious threat to the ratification and implementation of the CRC and other related international conventions in the Muslim world. ${ }^{38}$ In this case, Islamic law seems to be commonly used by Muslim countries as an excuse to breach the treaty on the basis that their reservations to the CRC justify only conditional application of the Convention.

\section{E. A Muslim for marriage, an apostate for divorce}

Despite the fact that interreligious marriage is not recognized in the Indonesian Marriage Law and is forbidden according to the compendium of Islamic law, it is in fact commonly practiced in Indonesian society. A variety of strategies are adopted by interreligious couples to ensure that their marriage is legalized in the country, including having their marriage registered outside Indonesia. This is among the reasons why the actual number of interreligious couples in Indonesia is difficult to identify; it is believed to be higher than the number recognized in government data. Another reason why the actual number is difficult to identify is because it is common for couples in Indonesia to convert 'temporarily' to another religion prior to the marriage, simply to have their marriage legalized. Some of them will return to their own religion following the marriage. To cite one example from interviews:

P2: I had one case recently. Interreligious couple, been married for 13 years and have five children, two boys and three girls. The wife is a Catholic and the man is a decent Muslim. They have their marriage registered here in this [religious] court. They were both registered as Muslims when they got married. You know, [the wife] temporarily converted to Islam prior to her marriage. In the ID, up till now, the wife remains registered as a Muslim, yet she has never been a Muslim at all. She was back to her religion even right after the marriage. Nothing has changed with her before and after the marriage.

Some cases of this kind come to light in court when the religious identities of couples are revealed in the course of applying for the dissolution of a marriage or for child custody. As further shared by $\mathrm{P} 2$ :

P2: ... for 13 years, they both enjoyed a happy marriage, actually. Both their boys are Muslims while the girls follow their mom, going to Catholic

36 Syed 1998: 360 .

37 McLean 1999.

38 see also Duncan 1999. 
[Church] every Sunday. From what I learned, different religion was not the main reason why they decided to divorce. The real issue raised in the mediation process was that the wife had an affair with a man from her office, a Muslim too. The husband used the issue of different religion mainly as he knows well that it would be a solid ground for him to divorce his wife.

'Temporary' religious conversions like this might not fit the definition of ridda (apostasy), of 'turning away from Islam' or 'severing the ties with Islam'39 since their act does not involve turning from or to certain theological beliefs or constitute theological insubordination. The 'apostate' couples were merely employing a shortcut to get around the marriage law that does not provide for interreligious marriage.

The Indonesian marriage law does not include any provision stipulating that conversion from or to Islam determines the validity of a marriage or can provide grounds for dissolving a marriage. However, according to Islamic jurisprudence, religious conversion or choosing a different religion provides grounds for divorce. ${ }^{40}$ All judges participating in this study held the belief that religious conversion or apostasy is regarded as a valid reason to dissolve a marriage.

P3: ... if the reason [for divorce] is because one of them has converted from Islam, then it won't be any question for me as a judge - divorce. The only thing that we have to find out here is whether it is true that one of them is an apostate.

The complexities in the practice of interreligious marriage in Indonesia have raised serious questions regarding the compatibility of some provisions within the family law with contemporary issues, including the discourse on human rights. P1, for example, asserts that the amendment of the Indonesian marriage law is necessary as some provisions are irrelevant to the contemporary context of Muslim society in Indonesia.

P1: ...I don't know why it is so difficult to amend this [marriage] law. The society has changed tremendously since 1974 . We need an update, we certainly need to address some contemporary issues which are not accommodated in the law we have now.

However, some other judges do not appear to see any serious problem within the family law. For example, P4 argues that religious freedom and interreligious marriage are entirely separate issues in Indonesia.

P4: The main Islamic principle in marriage is between man and woman from the same religion, between Muslims ... We do not accommodate interreligious marriages. Yet, for me, it has nothing to do with freedom of religion.

39 Peters \& De-Vries 1976: 2-3.

40 Berger 2003: 723; Hak 2012. 
People might change their religion ten times a day if they want, they have all the rights to do so, so please just do it. If that is your decision, then you have to take all the consequences.

The same opinion is shared by $\mathrm{P} 3$ :

P3: If they know well that it (interreligious marriage) is forbidden then why they still do it. Why now they ask for solution when they face problems and difficulties. They simply ignore Islam when they decided to get married. They were hiding from us and played some tricks to get married, but now they will come to us for help. If I have to give an answer I would rather tell them 'kono urusi dewe' (Javanese: deal with it yourself).

The responses given by the religious judges highlight that freedom of religion is not seen to be applicable in Indonesia in the context of marriage. Conversion from Islam, or even an accusation of apostasy, is regarded as solid grounds by religious judges to dissolve a marriage. Laws and regulations concerning religious freedom, including Law No.12/2005 (ratification of the ICCPR), are not even referred to by the judges in their verdicts in response to issues related to apostasy and interreligious marriage. Indeed, some provisions of the marriage law and the compendium of Islamic law are at odds with contemporary human rights discourse.

Family law is considered the core of sharia among Indonesian Muslims and any attempt to change this law always triggers controversy. Some Muslims consider family law to be sacred so that any proposed changes to this law are often translated as corrupting the core of the religion. This may have contributed to a lack of discussion about such contemporary issues as interreligious marriage, freedom of religion, and human rights in general even among religious judges. Judges often display ambivalent attitudes in response to human rights issues. On one hand, they declare that, by virtue of their strategic position, they are duty-bound to protect the rights of civilians, particularly those who are victims of injustice, yet on the other hand they tend to use Islamic provisions to refuse the application of human rights principles.

Furthermore, such an ambivalent approach has been a common phenomenon in Muslim countries in relation to human rights principles ${ }^{41}$, by which sharia provisions are used as grounds for refusing to implement human rights principles in their domestic legislation. ${ }^{42}$ Muslim countries, on the one hand, seem to be prepared to accommodate the modern concept of human rights, but on the other hand, attempt to preserve their traditional Islamic law. ${ }^{43}$ The same case also occurs in the implementation of the ICPPR in Indonesia. Despite the positive response to the covenant when it was ratified through Law No.12/2005, implementation of the convention within domestic policies and programs in Indonesia has been problematic.

41 Arzt 1990; Bielefeldt 2000.

42 see also Arzt 1996.

43 Bielefeldt 1995; 2000. 


\section{F. Custody disputes and violation of children's rights}

With respect to child custody and guardianship in Islam following the separation or divorce of the parents, fundamental rules vary among schools of Islamic jurisprudence (fiqh). However, there is general agreement among the schools of Islamic law, not only among the four major Sunni schools but also among the Shiites ${ }^{44}$, that the mother has the priority claim to child custody. ${ }^{45}$ As also noted by Pearl ${ }^{46}$, the core principles are the same in all schools, by which the responsibility for a child in his or her early life falls to the mother and the responsibility will be the father's in his or her later life. All schools, however, hold that the mother will lose her priority claim for custody if she remarries. ${ }^{47,48}$

In the discourse of children's rights and human rights in general, the Islamic concept of custody, which gives priority to the mother in cases of divorce, is regarded as among the landmarks of children's and women's rights in Islam. This provision is commonly used to support the argument that the concept of preventing a separation between a mother and her infant was incorporated into Islamic law even before international legislation was developed to address this issue. Furthermore, the provision is often used as an argument to deny that gender discrimination exists in Islamic family law. ${ }^{49}$

P3: It has been far before the international society even thinks about child welfare, we in Islam have had developed a strong concept of how children and women have to be protected ... the importance of breastfeeding, prioritizing custodial rights of the mother, children have their rights as independent individuals ... [T] hese show that our concept is actually more advanced than the international convention itself.

The question remains whether the Islamic norms for prioritizing a mother for child custody can really justify the position that a strong concept of protecting the rights of women and children is embedded in Islam. Regardless of the custody status of a child, there is agreement among schools of Islamic law that the father is responsible to provide financial support for the maintenance and education of the child. ${ }^{50}$ However, there are strong indications from the findings of this study that some fathers take advantage of the poor enforcement of this provision in Indonesia. The lack of

44 Ebrahimi 2005; Goolam 2006: 127.

45 Coulson, 1964: 96; Davis 1985; Moosa 1998; Nasir 2002.

46 Pearl 1998.

47 Nasir 2002; Goolam 2006.

48 This condition is referred to a Hadith narrated by Abu Daud and Hakim: 'You (the wife) have the first right to the child as long as you do not marry' (Sunan Abu Daud, Kitab at Talaq (2): 616-617).

49 Hoballah 2006; Goolam 2006.

50 Nasir 2002; Ebrahimi 2005; Hashemi 2007. 
enforcement has made it easy for them to neglect their obligation to provide financial support for their children after divorce.

In practice, the argument that the Islamic concept of child custody is advantageous for women appears to be a fallacy. Giving the priority to women for child custody does not always mean that women and children are advantaged. With poor law enforcement in Indonesia, winning child custody in the court can be a disaster for some women, as it might mean they have to struggle themselves to support their children. On the contrary, losing child custody might be used by some fathers to justify their denial of their responsibilities to provide financial support for their children and their ex-wives.

P1: Some women end up struggling by themselves to support their children as their ex-husbands are simply neglectful, especially when they (ex-husbands) finally marry other women and have new families.

P2: The common problem that occurs after divorce is that after three or four months some husbands fail to give financial support for the children as decided in the court verdict. It is sad as there is no good control from the police or court in responding to this case ... [N]o action can be carried out unless [the mother] brings the case to the police or the court.

Moreover, based on arguments given by most Muslim jurists, it appears that the custodial priority for a mother is mainly based on her responsibility to take care of the child, especially when there is an infant who needs breastfeeding ${ }^{51}$, and is not based on the principle that a mother can be a sole guardian of her child. As noted above, the custodial rights will fall to the father in the later life of the children.

Two full years is the period of breastfeeding recommended in the Quran (2:233) and Hadith which, as noted by Giladi ${ }^{52}$, was also the tradition in Middle Eastern societies before Islam. This appears to be the main reason why separation between a mother and her infant is prevented in Islam and that a mother is prioritized for child custody in cases of divorce. This implies that the rights of a mother for child custody are limited to the context of a child's physical custody. In fact, there will be a transfer of parental rights and responsibilities in the later life of the child, from physical custody of an infant given to the mother (had̄āna) into a child guardianship (wilāya) given to the father. ${ }^{53}$

The strong emphasis on breastfeeding in Islam, moreover, often stipulates oppression against mothers who, for some reasons, are unable to perform their duty. Mother's failure in performing her duty of breastfeeding her infant is commonly

51 Nasir 2002: 158-160.

52 Giladi 1999: 9.

53 Pearl 1998: 87; see also Ebrahimi 2005: 463. 
stigmatised as against nature. ${ }^{54}$ In cases of divorce, the failure of a mother to breastfeed her child will likely contribute to her failure to be granted child custody.

P3: There are ways to find out whether she (a mother) is a capable good mother or not. It is commonly assumed that every mother will automatically love her children. Don't get it wrong, not all mothers are capable of doing parental duties. For example, some mothers show their unwillingness to breastfeed their infants. They care about their beauty and careers more than their infants. You won't regard them as good mothers, will you?

The reality is that, in some Muslim communities, a marriage in often defined as a contract in which the husband assumes power ${ }^{55}$ as a 'quasi-purchaser' of the wife. ${ }^{56}$ The patriarchal system of marriage forces women to devote themselves to their husbands' authority and obliges women to breastfeed their children. The belief is that the actual owner of the milk is the husband, while the wife is often seen simply as 'the milk hostess' ${ }^{57}$ In fact, the majority of Muslim prominent jurists, including the Shafiis, the Hanafis, and the Hanbalis ${ }^{58}$, give strong emphasis to the concept that the husband is the one who is entrusted with full responsibilities for the wellbeing of his wife and his children and has the right to an assurance that the infants will get the benefit of breast milk.

Issues related to child custody become more complex when interreligious marriages or issues of apostasy are involved. In cases of child custody disputes among interreligious couples, it appears from the responses given by the judges interviewed that Islamic norms regarding the division of responsibilities between father and mother can easily be neglected, since the primary focus of a verdict relates to the children's religion. In such cases, judges might simply disregard the best interests of the child as most of them will automatically grant custody to the Muslim parent (father or mother) regardless of their capacity to provide appropriate parenting for the child.

P2: It is clear in the Islamic provision that a child born from interreligious marriage, for any reason, has to be kept Muslim. In the case of divorce, the custody has to be given to the Muslim parent (father or mother). It is against the most important provision in Islam if a child is given to the non-Muslim parent.

P1: In divorce cases involving interreligious couple, most religious judges will grant the child custody to the Muslim parent, husband or wife, as that is the mainstream understanding among judges toward Islamic provision of child custody, in which a child has to be under the care of Muslim parent.

54 Al-Minawi 1993; Giladi 1998; Mohd 2011.

55 Mulia \& Cammack 2007.

56 Coulson 1964: 15.

57 Giladi 1998: 116.

58 al-Nawawī 1995: 52; al-Țabarī 1995 [2]: 495; Mohd 2011: 658. 
The arguments given by the judges above raise serious concerns regarding a 'collective denial ${ }^{59}$ among some religious judges in Indonesia of the fact that the verdicts regarding the custody of children from interreligious marriage, which is almost invariably given to the Muslim parent (father of mother) regardless of his or her parental competence, constitutes a serious violation of children's rights. It appears that most religious judges base their verdict on religious allegiance rather than the best interests of the child, as they ignore the plight of children who might be placed at risk by being given over to the custody of a parent who might be abusive or incapable.

It is interesting as all religious judges participating in this study emphasize the belief that the concept of religious freedom does exist in Islam. However, at the same time they also argue that the concept is not applicable in the context of parents and children. Furthermore, all the judges, including those who appear to have progressive views, emphasize that freedom of religion as mentioned in the $\mathrm{CRC}$ is not applicable in the context of Muslim communities in Indonesia.

P3: There is a very strong concept of religious freedom in Islam, yet this is not applicable in the context of parents and children as parents are obliged to keep their children in the way of Allah.

P4, furthermore, emphasizes this belief by explaining that making a child a good Muslim is the most important obligation of every Muslim parent. Indeed, it is commonly believed among Muslims that Muslim parents are strongly obliged to keep their children as Muslims. ${ }^{60}$

P4: Teaching religion, making children good Muslims, is one of the most important responsibilities of Muslim [parents], so the Western idea of giving freedom for children to choose their own religion, which may be different from their parents', is not acceptable in Islam. Parents need to make every possible effort to keep their children Muslims. They have to work hard for it ... As mentioned in some verses [of the Quran] that it is the parent that first will be dragged to hell, not their children, for sins committed by their children resulting from their failure in teaching Islam to the children.

The threat of being 'dragged to hell' has made some Muslim parents, especially those from interreligious marriages, particularly fearful of failing to keep their children in their custody. Some Muslims will take these warnings more seriously than the others. In some cases, the threat of being 'dragged to hell' results in serious depression. P1 described how a mother suffers a serious depression following her failure in her battle with her non-Muslim husband for child custody as she believes that she deserves serious punishment for her failure in saving her child in the path of Allah.

59 Beckett 1996: 61.

60 Hashemi 2007. 
P1:... She told me that she finally realized that it is a big sin for her to marry non-Muslim, yet she even feels more guilty as she believes that she has failed in protecting her son from hell ... She believes that it will be a big sin for her as she let her son to follow [the religion of] her ex-husband, which is other than Islam.

It is evident that most religious judges, as reflected from their responses in connection with some of issues discussed above, are more closely bound to fiqh (Islamic jurisprudence) than to state laws. Even though the judges do not explicitly oppose the enforcement of state law, their verdicts show that they are bound by state law only when it is seen to conform to religious values and provisions. In cases where state law is not compatible with Islamic provisions, as in the case of custodial rights for parents from interreligious marriage, they will reject and oppose the enforcement of the state law.

Unfortunately, the system of religious courts in Indonesia is not equipped with a mechanism to review and monitor the competence of religious judges with regard to contemporary discourse of children's rights and human rights in general. Moreover, as further noted by $\mathrm{Ka}^{\prime} \mathrm{bah}^{61}$, there has never been an evaluation of the extent to which verdicts issued by judges in religious courts are based on the spirit of Islamic law itself as derived from the Quran and Hadith. The recent transformation of religious courts in Aceh into Sharia courts ${ }^{62}$, on the contrary, shows that religious courts and judges may pose serious obstacles to government attempts to promote human rights principles in the future.

\section{G. Conclusion}

The findings of this study show that apostasy or adherence to a different religion is regarded as valid grounds for divorce by most religious judges in divorce cases in Indonesia. This is among the reasons why an accusation of apostasy appears to be commonly used by couples to dissolve their marriage, especially in religious courts. Apostasy also provides grounds in cases of child custody disputes. The responses given by the judges illustrate how most religious judges base their verdicts on religious allegiance rather than on the best interests of the child or on human rights principles in general. Most of them appear to automatically grant custody to the Muslim parent (father or mother) regardless of their capacity to provide appropriate parenting for the child, which might place the child at risk.

Furthermore, the interviews highlight the fact that religious judges can hold a very strategic position, through their verdicts, in addressing problems related to violations of children's rights and human rights in general. Unfortunately, a lack of sufficient knowledge concerning child welfare has rendered their significant roles

$61 \mathrm{Ka}$ 'bah 2007.

62 Lindsey \& Hooker 2007; Feener et al. 2011. 
counterproductive, as their verdicts can be detrimental to the promotion of human rights principles in society. Moreover, as noted above, some verdicts of the religious judges reflect their ambivalent attitude in response to human rights issues. These judges see themselves as duty-bound to promote human rights and public welfare. However, at the same time they tend to use Islamic provisions to refuse the application of human rights principles. It is not an exaggeration to argue that the introduction of modern discourse on children's rights, and human rights in general, to Muslim communities in Indonesia might be seen as an attempt to introduce modernity into the Islamic world. Serious debates will always persist while success in finding an intersection between the two discourses - Islam and human rights - remains elusive.

\section{References}

Aini, N. (2008): Inter-religious marriage from socio-historical Islamic perspectives, in: Brigham Young University Law Review 3.

Arzt, D. (1996): Religious human rights in Muslim states of the Middle East and Northern Africa, in: Emory International Law Review 10 (1), 139-161.

- (2002): The role of compulsion in Islamic conversion: jihad, dhimma and ridda, in: Buffalo Human Rights Law Review 8, 15-44.

Beckett, K. (1996): Culture and the politics of signification: the case of child sexual abuse, in: Social Problems 43, 57-76.

Berger, M. S. (2003): Apostasy and public policy in contemporary Egypt: an evaluation of recent cases from Egypt's highest courts, in: Human Rights Quarterly 25(3), 720-740.

Bielefeldt, H. (2000): "Western" versus "Islamic" human rights conceptions?: A critique of cultural essentialism in the discussion on human rights, in: Political Theory 28(1), 90121.

Butt, S. (2010): Islam, the state and the Constitutional Court In Indonesia, in: Pacific Rim Law \& Policy Journal Association 19(2), 279-301.

Clarke, B. (2009): Law, religion and violence: a human rights-based response to punishment (by State and non-state actors) of apostasy, in: Adelaide Law Review 30(1), 111-147.

Coulson, N. J. (1964): A history of Islamic law. Edinburgh: Edinburgh University Press.

Duncan, W. (1998): Children's rights, cultural diversity and private international law, in: Gillian Douglas \& Leslie Sebba (eds.), Children's Rights and Traditional Values. Aldershot: Ashgate \& Dartmouth.

Ebrahimi, S. N. (2005): Child custody (hizanat) under Iranian law: an analytical discussion, in: Family Law Quarterly 39 (2).

Eid, T. Y. (2005): Marriage, divorce, and child custody as experienced by American Muslims: religious, social, and legal considerations. (PhD Thesis), Harvard University, Cambridge Massachusetts.

Feener, R. M., P. T. Daly \& A. Reid (2011): Mapping the Acehnese past. Leiden: KITLV Press.

Ghazali, A. M. (2012): Hukum Nikah Beda Agama. Retrieved 24 April 2013, from Jaringan Islam Liberal http://www.islamlib.com/?site=1\&aid=1743\&cat=content \&title=kolom 
Giladi, A. (1999): Infants, parents and wet nurses: medieval Islamic views on breastfeeding and their social implications. Leiden: Brill.

Goolam, H. N. (2006): Gender equality in Islamic family law: dispelling common misconceptions and misunderstandings, in: H. M. Ramadan (ed.), Understanding Islamic law: from classical to contemporary. Lanham, MD: Rowman \& Littlefield Publishers, 117134.

Hak, N. A. (2012): Rights of a wife in the case of conversion to Islam under family law in Malaysia, in: Arab Law Quarterly 26, 227-239.

Hallaq, W. (2009): An introduction to Islamic law. Cambridge: Cambridge University Press.

Hashemi, K. (2007): Religious legal traditions, Muslim states and the Convention on the Rights of the Child: an essay on the relevant UN documentation, in: Human Rights Quarterly 29(1), 194-227.

Haynes, J. (2001): Transnational religious actors and international politics, in: Third World Quarterly 22(2), 143-158.

Hoballah, M. (2006): Marriage, divorce, and inheritance in Islamic law, in: H. M. Ramadan (ed.), Understanding Islamic law: from classical to contemporary. Lanham, MD: Rowman \& Littlefield Publishers, 111-116

Johansen, B. (2003): Apostasy as objective and depersonalized fact: two recent Egyptian court judgments (Part II: Islamic law: boundaries and rights), in: Social Research 70 (3), 687.

Ka'bah, R. (2007): Islamic law in court decisions and fatwa institutions in Indonesia, in: R. M. Feener \& E. M. Cammack (eds.), Islamic law in contemporary Indonesia. New York: Cambridge University Press, 170-192.

Kirby, M. (2008): Fundamental human rights and religious apostasy: the Malaysian case of Lina Joy, in: Griffith Law Review 17(1).

Langlaude, S. (2007): The right of the child to religious freedom in international law: international studies in human rights. Boston: Martinus Nijhoff.

Langlaude, S. (2008): Children and religion under Article 14 UNCRC: a critical analysis, in: The international journal of children's rights 16(4), 475-504.

Lindscy, T., \& M. B. Hooker (2007): Shari'a revival in Aceh, in: R. M. Feener \& E. M. Cammack (eds.), Islamic law in contemporary Indonesia. New York: Cambridge University Press, 193-215.

Marshall, P. (2010): Ambassador to Islam? The United States shouldn't legitimize the OIC, in: The weekly standard 15(23).

Mawdoodi, S. A. A. 1. (1983): The laws of marriage and divorce in Islam. Kuwait: Islamic Book Publishers.

McLean, D. (1999): Perspectives on universal ratification, in: S. Detrick \& P. Vlaardingerbroek (eds.), Globalization of child law: the role of the Hague Conventions. Boston: Martinus Nijhoff Publishers, 77-86.

Al-Minawi, K. M. (1993): The child rights in Islam. Riyadh: Dar Al-Amal Publishing House.

Mohd, A. (2011): Breastfeeding (Rada'ah) under Islamic law and it's promotion towards sustaining mother's and children's health. Paper presented at the The Asian Conference on the Social Sciences (ACSS), Osaka, Japan.

Moosa, N. (1998): Muslim personal laws affecting children: diversity, practice and implications for a new Children's Code for South Africa, in: South African Law Journal 115, 479-492. 
Mosaffa, N. (2011): Does the Covenant on the Rights of the Child in Islam provide adequate protection for children affected by armed conflicts?, in: Muslim World Journal of Human Rights 8 (1).

Mulia, S. M., \& M. E. Cammack (2007): Toward a just marriage law: empowering Indonesian women through a counter legal draft to the Indonesian compilation of Islamic law, in: $\mathbf{R}$. M. Feener \& M. E. Cammack (eds.), Islamic law in contemporary Indonesia: ideas and institutions. Cambridge/Mass.: Harvard University Press, 128-145.

Nasir, J. (2002): The Islamic Law of Personal Status. New York: The Hague.

Al-Nawawī, M. Y. (1995): Rauda al-țālibìn wa umda al-muttaqīn (vol. 8). Bayrūt: Dār alFikr.

O'Sullivan, D. (2003): Egyptian cases of blasphemy and apostasy against Islam: Takfir alMuslim, in: The International Journal of Human Rights 7(2), 97-137.

Pearl, D. (1998): A note on children's rights in Islamic law, in: G. Douglas \& L. Sebba (eds.), Children's rights and traditional values. Aldershot: Ashgate/Dartmouth, 86-92.

Peters, R., \& G. De-Vries (1976): Apostasy in Islam, in: Die Welt des Islams 17(1/4), 1-25.

Rajabi-Ardeshiri, M. (2009): The rights of the child in the Islamic context: the challenges of the local and the global, in: The International Journal of Children's Rights 17, 475-489.

Rehman, J. (2010): Freedom of expression, apostasy, and blasphemy within Islam: sharia, criminal justice systems, and modern Islamic state practices, in: Criminal Justice Matters, 79(1), 4-5.

Saeed, A., \& H. Saeed (2004): Freedom of religion, apostasy and Islam. Burlington: Ashgate Publishing.

Shaikh, F. (ed.) (1992): Islam and Islamic groups: a worldwide reference guide. Harlow/ Essex: Longman Current Affairs.

Syed, S. (1998): The impact of Islamic law on the implementation of the Convention on the Rights of the Child: the plight of non-marital children under shari'a, in: The International Journal of Children's Rights 6(4), 359-393.

Al-Ṭabarī, M. (1995): Jāmi 'al-bayān 'an ta'wīl al-Qur'ān (Vol. 18). Bayrūt: Dār al-Fikr. 


\title{
Fatwa of the Indonesian Council of Ulama (MUI) on Ahmadiyah and its impact on Ahmadi women and children
}

\author{
Saifuddin
}

\section{Introduction}

\begin{abstract}
Ahmadiyah is an Islamic reformist movement founded in India near by the end of the 19th century. It originated with the life and teachings of Mirza Ghulam Ahmad (1835-1908) ${ }^{1}$, who claimed to have fulfilled the prophecies of the world reformer at the end of time, who was to herald the Eschaton or day of judgement as predicted in the traditions of various world religions and bring about the final triumph of Islam as per Islamic prophecy. He claimed that he was the Mujaddid (divine reformer) of the $14^{\text {th }}$ Islamic century, the promised Messiah and Mahdi awaited by Muslims. The adherents of the Ahmadiyah movement are referred to as Ahmadis or Ahmadi Muslims.
\end{abstract}

Ahmadiyah has been legally acknowledged in Indonesia since 1928. They also took part in struggling for the country's independence against the Dutch colonialism. For about a century, Ahmadiyah has been able to live at peace with different social groups in the plural Indonesia. However, when the MUI (literally, the Council of Indonesian Islamic Clerics) was established in July 26,1975, this coexistence was destroyed and Ahmadiyah was questioned in terms of its doctrinal and legal basis.

Five years after its establishment, the MUI released a legal opinion (fatwa) that Ahmadiyah is un-Islamic, heretical and misleading (ضض مضل). This fatwa on Ahmadiyah was then reconfirmed at the $7^{\text {th }}$ national conference of the MUI in Jakarta 24-29 of July 2005. At the end of 2007, there was a strong demand upon the Indonesian government to ban Ahmadiyah in Indonesia. The demand was accompanied by violent acts against the Ahmadis, especially against Ahmadi women, and that violence seems to continue up to recent times. Since then, the fatwa became a con-

1 Concerning the discussion on his birthday, there are two versions that mention different years of his birth. The first version as written by Hamka Haq al-Badry at his work, Koreksi total terhadap Ahmadiyah, (Jakarta: Yayasan Nurul Islam, 1980), p. 24, mentioned 1252 Hijriah/1835 AD. The second version mentioned $1839 \mathrm{AD}$ as written by Abū al-'A 'lā alMawdūdī in his work, Mā hiya al-qādiyānīya? dirāsa shāmila wa- 'ard 'ilmī li-al-qādiyānīya wa-madā ta'firihīa fi al-mujtama a al-islāmī, published in 1969, p. 9, and the work of Abü alal-Hasan 'Alī al-Nadwī, Al-qädiyān̄̄ wa al-qādiyyānìya: dirāsa wa-tahlīl, vol. IV, (Jeddah: alDār al-Sa ūdīya li-al-Nashr, 1971), 23-24. 
troversial topic: some critisize that the fatwa gives a legal basis for such violent acts but others still support it.

This paper examines the MUI fatwa on Ahmadiyah, including its nature, its definition, its context as well as its target and lastly its impact on Ahmadi women and children as the most suffering and direct victims. The significance of this paper is to is also to clarify the position of fatwas in the Muslim community. Besides, it describes the methodology used by the MUI to issue the fatwa. Using a content or textual analysis in examining the fatwa, this paper aims to disclose what is behind the fatwa, and what the impact on Ahmadi women and children is.

\section{What is a fatwa?}

A fatwa in Islamic faith is a religious opinion on Islamic law issued by an Islamic scholar. In Sunni Islam any fatwa is non-binding, whereas in Shiite Islam it could be, depending on the status of the scholar. ${ }^{2}$ Based on the above definition a fatwa is one of kind of Islamic law (figh). As is commonly known fiqh may consist of books of figh, of comparative law, jurisprudence, individual laws, legal opinions (fatwa), and other forms of law which are binding such as compilations of Islamic law, constitutions, codifications of law, international treaties, declarations of human rights, letters of contract, testaments, testimonials, etc.

According to the $u s \underline{u} l$ al-fiqh (principles of Islamic jurisprudence), in order to be valid, a fatwa must meet the following conditions:

1. The fatwa is in line with relevant legal proofs, deduced from Qur'anic verses and Hadiths; provided the Hadith was not later abrogated by Prophet Muhammad (pbuh).

2. It is issued by a person (or a board) having due knowledge and sincerity of heart;

3. It is free from individual opportunism, and not depending on political servitude;

4. It is adequate with the needs of the contemporary world.

In the Qur'an, a fatwa sometimes appears in the form of word بينّلو see for examples at verses of al-Baqarah: 189, 219, and بينفتون see for examples at verse of alNisā' 176 . In Hadiths, some of the words of the Prophet resulted from questions of of his companions.

\section{The MUI's fatwas concerning Ahmadiyah}

In 1980 the MUI issued a fatwa (Number: 05/Kep/Munas II/MUI/1980) on Ahmadiyah. Then in 2005, the MUI reproduced the same fatwa (Number: 11/MUNAS VII/MUI/15/2005). The complete content of the latter fatwa is as follows:

2 Ibid. 


\author{
DECREE OF THE COMMITTEE \\ OF THE COUNCIL OF INDONESIAN ULAMA \\ Number : 11/MUNAS VII/MUI/15/2005 \\ On AHMADIYAH
}

Council of Indonesian Islamic Clerics (MUI), at its Seventh National Conference, 19-22 of Jumadil Akhir 1426 H./ 26-29 of July 2005 AD. after READING:

a. That until right now, Ahmadiyah keeps trying to develop its doctrines in Indonesia, even though there was a fatwa of MUI and its existence is forbidden;

b. That the efforts to develop the Ahmadiyah unsettle the society;

c. That some groups of society ask for re-confirmation of a fatwa of MUI on Ahmadiyah related to the appearance of several opinions and reactions from society;

d. That to fulfill social demand and to keep the pure creed of Islam, MUI thinks it is necessary to reconfirm the fatwa concerning Ahmadiyah.

\title{
REFERRING TO:
}

1. Word of Allah SWT.,

"Muhammad is not the father of any of your men, but he is the Messenger of Allah and the last of the Prophets. And Allah is the All-Knowing. (Al'Ahzab [33]: 40)

"And verily, this is My straight path, so follow it, and follow not (other) paths, for they will separate you away from His path. This He has ordained for you that you may have Taqwa." (Al-'An'ām [6]: 153)

"O you who believe! Take care of yourselves. If you follow the right guidance, no hurt can come to you from those who are in error. The return of you all is to Allah, then He will inform you about (all) that you used to do." (Al-Mă'ida [5]: 105)

2. The Hadith of prophet Muhammad S.A.W.; such as: "Rasulullah said: There is no prophet after me" (reported by al-Bukhari).

"Rasulullah said: the apostolate and prophecy is already disconnected; therefore, there is no Messenger or prophet after me" (reported by Tirmidzi).

TAKING INTO CONSIDERATION:

1. The decision of Mujamma' al-Fiqh al-Islāmī of the Organization of Islamic Conference Number $4(4 / 2)$ at its Second Conference in Jeddah, Saudi Arabia, on 10-16 Rabi' al-Thānī 1406 H./22-28 of December 1985 AD. concerning the Qodiyaniyah sect among others stated that Ahmadiyah followers who believe in Mirza Ghulam Ahmad as a prophet after prophet Muhammad and received a revelation/wahy are apostate and outside Islam because they refused the uncontested doctrine of Islam and 
a consensus of the whole of Moslem scholars that Muhammad s.a.w. is the last Prophet and Messenger. [...]

2. The fatwa decision of Second National Conference of the MUI in 1980 on Ahmadiyah Qodiyaniyah.

3. The opinions of Committee C about fatwa Seventh National Conference of the MUI in 2005.

By trusting in Allah SWT

\section{DECIDED/ISSUED A FATWA ABOUT \\ THE AHMADIYYA SECT AS FOLLOWS:}

1. Reconfirmation the fatwa of the MUI at its Second National Conference in 1980 which decided that Ahmadiyah is outside Islam, misled, and misleading, and Muslims who follow them are godless.

2. They who follow Ahmadiyah should return to the true teaching of Islam (al-rujü ' 'ila al-haqq), that is fitting to the Qur'an and Hadith.

3. The government has the obligation to prohibit the spreading of the doctrines of Ahmadiyah in Indonesia, to congeal this organization, and to close down all the places of its activities.

This fatwa was released on 22 of Jumadil Akhir 1426 H./29 of July 2005 AD. and signed by KH. Ma'ruf Amin and Hasanuddin. They are the general chairman and the general secretary of MUI.

\section{The Position of the MUI fatwa}

This fatwa is addressed to Ahmadiyah and its followers and the government of Indonesia. For the first addressee, it judges that Ahmadiyah is a heretical and misled organization, so its followers have to go back to the true teachings of Islam. However, the question arises now as to which teaching of Islam the followers of Ahmadiyah have to go, because in Islam itself there are so many schools of thought. For the second addressee, it asks the Indonesian government to stop the spreading of Ahmadiyah's doctrines, even to congeal and close the organization.

Concerning the second addressee, the MUI does not have the power or authority to force the fatwa to be applied. Therefore, the MUI only appeals to the Indonesian government to take over the law matters. Yet, according to Islamic law, the appealing itself was an act of law, because the Islamic law does not only relate to obeying or disobeying certain rules that are sanctioned, but also to morals. ${ }^{3}$

The MUI or Council of Indonesian Islamic Clerics is an organization that contains 'ulamā', zu 'amā', and intellectual Muslims in Indonesia to guide and guard the entire muslim community of Indonesia. It was established on $7^{\text {th }}$ of Rajab, 1395

3 Mudzhar 1999: 23. 
H./26 ${ }^{\text {th }}$ of July, $1975 \mathrm{AD}$. in Jakarta as a recommendation body of 'ulamá', zu 'amā', and intellectual Muslims of Indonesia. Five functions were formulated:

1. as a heir of prophet's tasks (waratha al-'anbiyā')

2. as a mufti

3. as a guide and a servant of the Umma (ri 'aya wa khādim al-umma)

4. as a reformation movement (isläh wa al-tajdìd)

5. as an upholder of amar ma' rüf nahy munkar.

Concerning the second function and role, i.e. as a mufti, the fatwas are carried out by the Fatwa Committee of the MUI. The committee is given the task of discussing and issuing fatwas on questions of Islamic law as encountered by society. Another mechanism for drawing up fatwas is by discussing all issues at the annual conference of the 'ulama ' held by the MUI. Such a conference, attended by a greater number and wider range of the 'ulam $\bar{a}$ ', addresses issues that call for the drawing up of the fatwas and, having agreed on certain issues and having provided the arguments, lists and submits the issues to the Fatwa Committee that later pronounces them in the proper form. ${ }^{4}$

\section{The Content of the fatwa}

The fatwas invariably commence with a statement that the committee has held meetings on certain days in response to certain questions posed by certain individuals or institutions. This is followed by the arguments on which the fatwa is based. The arguments vary in length and depth for different fatwas. For most fatwas the argument is opened with the Qur'anic bases followed by relevant Hadiths and quotations from Arabic fiqh texts. Rational arguments are also supplied in support. There are even fatwas that do not employ propositions at all. After showing the considerations, the statement of fatwa is placed at the final part of the decree. Thus, it can be concluded that methodologically a fatwa does not follow a fixed pattern. ${ }^{5}$

Theoretically, the order of sources of determining Islamic law (ithtinbāt alahkām) applied in Indonesia is the order according to the Shafi'i school of law, i.e.: al-Qur'an, Hadith, 'ijmā', and qiyās. However, at a practical level, such a methodological procedure is not always followed. ${ }^{6}$

The fatwa concerning Ahmadiyah methodologically refers to some verses of alQur'an and some Hadiths. The verses used as a base of argumentation are Al-'Ahzāb [33]: 40, Al-'An 'ām [6]: 153, and Al-Mā'ida [5]: 105. Whereas some traditions used are "No prophet after me" and "the apostolate and prophecy disconnected; therefore,

4 Mudzhar 1993: 68-69.

5 Ibid.: 69 .

6 Ibid.: 140 . 
no Messenger or prophet after me". I will analyze the employing of some verses of the Qur'an and some traditions.

The occasion of revelation of verse Al-Ahāäb: 40 was according to the report of Muhammad ibn 'Imā ra who told the story of Zaid ibn Hāritha. The verse abrogates his status as a son in law of prophet Muhammad. By this abrogating it is not forbidden for Muhammad to marry Zaid's ex-wife, because he is not Zaid's father but the last prophet, and no one after Muhammad could be a prophet. Another report comes from Bishr who stated that it is not only about Zaid (step son of Muhammad), but also about Qāsim, Ibrāhīm, Țayyib, and Muțahhir (sons of Muhammad). ${ }^{7}$

There is a deviation of the reading of the words خاتم النبيين. The Egyptian reading except Hasan and 'Āṣim recites خاتم

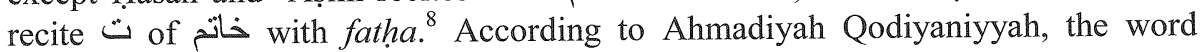
khātam is different from khātim. For them, khâtim would mean the last, but khātam means seal. ${ }^{9}$ Based on this definition, Qodiyani believe that Muhammad, peace be upon him, is the great Messenger, but Mirza Ghulam Ahmad is also a prophet after him.

This belief is not only opposed by Sunni Islam, but also by Ahmadiyah Lahore. They believe that Muhammad is the last prophet and Mirza Ghulam Ahmad is only a reformer. According to them, Mirza Ghulam Ahmad never proclaimed himself a prophet. His statement at Tafsir Qanun Asasi runs as a follows:

"I never confess to be a prophet, my confession is only as a muhaddath and it is based on the command of Allah. If it is called as a prophecy in allegorical meaning or "nabi juz' $\overrightarrow{1}$ " (a part of prophecy), so this confession does not mean a confession as a prophet". ${ }^{10}$

Al-Tabarī explained some reports of the occasion of verse Al-'An'ām: 153. One of them is a report from Ibn 'Abbās, who stated that Muslims should establish religion and make no divisions in it. This command is similar to the command in the Qur'an that states that Allah commanded the believers to adhere to the jama $\bar{a}^{\prime} a$ and forbade them causing divisions and disputes. He informed them that those before them were destroyed because of divisions and disputes in the religion of Allah. Another report from Ibn Zaid stated that the meaning of صبيله and صر اطنه islam, so never follow another way except Islam. ${ }^{11}$

The verse of Al-Mā'ida: 105 explains that Allah commands His believing servants to reform themselves and to do as many righteous deeds as possible. He also informs them that whoever reforms himself, he would not be affected by the wickedness of the wicked, whether they were his relatives or otherwise. Tabātabā' $\overline{1}$ (1321 $\mathrm{H}-1402 \mathrm{H}$ ) stated that this verse commands the mu'minin to always keep going a

7 Al-Țabarī 1398/1978: 12-13.

8 Ibid.: 13.

9 Ahmad 1968: 16.

10 Tafsir Qanun Asasi: 89.

11 Al-Ṭabarī: 65. 
way which leads to a guidance. They would never be influenced by a way of whom will lead them to be lost. ${ }^{12}$

Related to the traditions "No Messenger after me" used by the MUI, Ahmadiyah Qadiyani interpreted the word " $b a$ ' $d$ " by meaning "take place" or "comparable with”. Mīrzā Bashīruddīn Maḥmūd Aḥmad said:

"The important word there is the after ( $b a^{\prime} d$ ). Strictly speaking a thing comes after another thing only when the first thing has finished and gone, so that the second thing can take its place". ${ }^{2}$

According to Qadiyani, the word "lā nabiyya ba' $d$ " at the tradition (Hadith) contains the understanding that no prophet can occupy the position of Muhammad, peace be upon him, as the greatest prophet with the status khätam al-nabiyyin. Prophets who come after him are only continuators of Islamic sharia and function as law-givers. According to M. Zafrulla Khan, the word ba'd also means "instead of" as he stated:

"We believe that the Qur'an is the Last Book and final law and that after it there can be no prophet till the end of days, in the sense of law-giver or recipient of the word of God independently of the Holy Prophet peace be on him. As God Almighty has pronounced the Holy Prophets. He implies that because of his spiritual eminence..."

Because of these propositions the MUI decided that Ahmadiyah in Indonesia is heretical and mislead (ضل مضل). So the key word of the fatwa is dalāl. The questions arise now as to what is heresy (ضעل), who has authority to decide that this is lost or not, can a human being or an organization decide it, etc. If we study the Qur'an as a main source of Muslim life, we can find some variants of dalāl in it. There are 191 terms of dalāl in the Qur'an, 26 terms of dalla, tadilla (al-Baqara: 282), dalalnā (al-Sajda: 10), d̦allū, aḍalla, ḍallan (al-Duha: 7), al-ḍāllin (al-Fātiḥa: 7 and al-Shu' arā' : 20), and tậlīl (al-Fìl: 2).

The term of dalāl itself ethimologically has some meanings: disappear, dead, hidden, useless, destroyed, false, forget, lost, confused, and antonym of hidāya (guidance). ${ }^{15}$ Epistimologically, it is turning about a right and straight way, or an antonym of hidāya. ${ }^{16}$

There are seven kinds and characteristics of daläl in the Qur'an. They are 1) dala $l$ that is related to faith, 2) that is related to worship, 3) that is related to social interactions, 4) that is related to morals/attitude, 5) that is related to reason/thought, 6) that is related to law, and 7) that is related to economy. ${ }^{17}$

12 Țabātabā'î 1972, vol. 6: 162-164.

13 Ahmad: 17.

14 Zafrulla Khan 1978: 43.

15 Al-Misrī 1990, vol. 11: 390-394.

16 Al-Ișfahānī 2002: 509.

17 Aibdi Rahmat 2007: 116-165. 
The fatwa of the MUI concerning Ahmadiyah can be included into the first category. However, the first category usually refers to the following suras, they are alNisā': 136 \& 88, al-Mā'ida: 12, al-Ahzāăb: 36, 'Āli 'Imrān: 167, al-Munāfiqūn: 1, al'An ām: 21, al-Qașaș: 59, al-'Ankabūt: 49, al-Naml: 27. The case of Ahmadiyah is disconnected to all these suras. For example sura al-Nisâ': 136 stated that the people who lost are those who disbelieve in Allah, His Angels, His Books, His Messengers, and Hereafter.

The question is, is Ahmadiyah in Indonesia like that what the MUI defined? The explanation of the Central Board of Jama'ah Ahmadiyah Indonesia can be a measurement. There are 12 statements of Indonesian Ahmadiyah followers about their faith, they are:

1. We, Indonesian Ahmadiyah, since beginning believe and say the testimony of faith (shahāda) as it is taught by the greatest prophet Muhammad peace be upon him, "there is no true God except Allah, and that Muhammad is the Messenger of Allah".

2. Since beginning we, Indonesian Ahmadiyah, believe that Muhammad is khātam al-nabiyyin (the last prophet).

3. Among our beliefs is that Hadhrat Mirza Ghulam Ahmad is a teacher, murshid, news, remembrance, and mubashshirāt barrier, founder, leader of the Indonesian Ahmadiyah who has the duty to strengthen dakwah and syi'ar of Islam that is brought by the prophet Muhammad peace be upon him.

4. To clarify that meaning of the word Rasulullah at 10 conditions of bai ' $a$ which have to be read by every candidate of Ahmadiyah follower is Muhammad peace be upon him, so we put the word Muhammad in front of the word Rasulullah.

5. We Ahmadiyah followers believe that there is no wahy after al-Qur'ān al-karīm that is sent down to the prophet Muhammad. The Qur'an and the sunna of the prophet are the sources of Islamic teaching that we have to hold on.

6. The Book Tadhkira is not a holy book of Ahmadiyah, it is only a documentation of spiritual experiences of Hadhrat Mirza Ghulam Ahmad that is codified and named Tadhkira by its followers in 1935, that is 27 years after his death (1908).

7. We Ahmadiyah followers will never condemn Muslims outside Ahmadiyah as $k a \overline{f i r}$, neither by saying nor by action.

8. We Ahmadiyah followers will never call mosques that we built by the name of Ahmadiyah's mosques.

9. We state that every mosque built and organized by Ahmadiyah followers is always open for every Muslim from any group.

10. We Ahmadiyah followers as Muslims do the marriage documentation at the office of religious affairs and we apply divorce matters and others at the office of religious court as proper institutions.

11. We Ahmadiyah followers will always keep increasing silaturahim and cooperate with all groups of Muslims and of the societiy as a social dedication to the progress of Indonesia. 
12. By this explanation, we as the central board of Indonesian Ahmadiyah hope especially that Ahmadiyah followers and generally all Muslims and Indonesian people to be able to understand it by spirit of Muslim brotherhood and the unity of Indonesia. ${ }^{18}$

If this is connected to the above explanation and the term of daläl in the Qur'an that is related to faith, it cannot be concluded that Ahmadiyah is lost, because Ahmadiyah followers still believe in Allah, His Angels, His Books, His Messengers, and Hereafter, as other Indonesian Muslims do as well.

\section{The Context of the fatwa}

A fatwa, truly, is non-binding but it bears extensive social and political impact, because some Indonesian Muslims (al- 'awāmm) can employ it as a legal and religious base to legitimize their actions. Finally, we can imagine what will happen, if they use violence in the name of the fatwa, in the name of God, in the name of Islam, in the name of $\bar{l} \bar{i} i$ ' $\bar{a}$ ' kalima Allāh.

The impact of the fatwa on social life cannot be proved easily, but according to Atho Mudzhar, the typology can be constructed from which inferences may be drawn. According to him, there are at least five typologies. Firstly, there are fatwas which received a high degree of publicity but triggered no controversy. Secondly, there are fatwas which neither received moderate publicity nor much reaction from society, these fatwas were received by Muslims without much notice. Thirdly, there are fatwas which received moderate publicity and triggered controversy but only within the Muslim community, while the government remains neutral. Fourthly, there are fatwas which received a high degree of publicity but triggered only a moderate controversy, while the government is in favor of the fatwa. Finally, there are fatwas which both received a high degree of publicity and triggered a high degree of controversy, while the government is opposed to the fatwas. ${ }^{19}$

We can include the fatwa on Ahmadiyah into the third category, namely a fatwa which received moderate publicity and triggered controversy but only within the Muslim community, while the government remains neutral.

The fatwa concerning Ahmadiyah to some extent bore social conflicts among Indonesian Muslims. In Lombok, some houses of Ahmadiyah followers were burnt, in Parung Bogor, West Java, some houses and a mosque of Ahmadiyah were also burnt. Some Ahmadiyah followers were chased and hunted, so that followers of Ahmadiyah feel not save in the state that has a constitution which guarantees safety for all people in it regardless of religion, faith, ethnic, tribe, and other social status.

Here the highlight of abuses to Ahmadis in Indonesia: September 2002 some people destroyed the Ahmadi mosque and houses in Pancor East Lombok; October

18 www.google.com/Konferensi Pers Amir Jemaat Ahmadiyah Indonesia di Baitul Quran. 19 Mudzhar 1993: 123. 
20, 2004 unknown people damaged an Ahmadi mosque in Manislor, Jalaksana, Kuningan, West Java; September 20, 2005 some people attacked an Ahmadi village, Neglasari, Sukadana, Campaka, Cianjur, West Java; April 27, 2008 some people damaged the Ahmadi mosque and school in Parakan Salak, Sukabumi, West Java; June 2, 2009 two unknown people tried to burn the Ahmadi mosque in Kebayoran Lama South Jakarta; July 14, 2010 a people's movement of anti Ahmadiyah sealed several government offices in Garut; July 29, 2010 a clash happened between some activists of Islamic organizations and Ahmadis in Manislor, Jalaksana, Kuningan, West Java; August 10, 2010 some activists of FPI (Front of Defenders of Islam) and The Unity Movement of Moslem Mankind destroyed the plank of the Ahmadiyah at An-Nur mosque Surabaya; October 1, 2010 six buildings belonging to Ahmadis at Kampung Cisalada, Ciampea Udik, Ciampea district, Bogor were burned; October 11, 2010 the local government of Garut banned Ahmadis; October 29, 2010 FPI and other Islamic organizations in Ciamis tried to seal the Ahmadi mosque; Nov 26, 2010 some Ahmadi houses were burned in Ketapang West Lombok; Dec 8, 2010 the local government of Tasikmalaya decided to ban some Ahmadiyah facilities; Dec 10, 2010 about one thousand students in Sukabumi West Java damaged the Ahmadi mosque at Panjalu, Warnasari; Dec 27, 2010 a school "al-Mahmud" belonging to Ahmadis at Kampung Rawa Ekek, Sukadana, Campaka, Cianjur, was burned by unknown people; Jan 28, 2011 An-Nushrat mosque belonging to Ahmadis in Makassar was attacked by FPI; Feb 6, 2011 three Ahmadis in Cikeusik, Pandeglang were killed, their houses were also burned; March 13, 2011 a mosque of Ahmadiyah at Kampung Cisaar, Cipeuyeum, Haurwangi, Cianjur was attacked; March 30, 2011 the house of an Ahmadiyah leader at Kampung Tolenjeng, Sukagalih, Sukaratu, Tasikmalaya was damaged by unknown people; Apr 4, 2011 Al-Mubarok mosque belonging to Ahmadis at Kampung Sindang Barang, Sindang Barang, West Bogor was sealed by the local government of Bogor; Feb 17, 2012 Nurhidayah mosque belonging to Ahmadis at Ciranjang street Kampung Cisaat, Cipeuyeum, Haurwangi, Cianjur, West Java was damaged; April 20, 2012 a mosque of Ahmadiyah at Kampung Babakan Sindang, Cipakat, Singaparna, Tasikmalaya was damaged; Oct 25, 2012 a mass of FPI Bandung Raya attacked a mosque "An-Nasir" at Astana Anyar; Feb 14, 2013 the local government of Bekasi warned Ahmadiyah followers who are worshiping at mosque "Al Misbah", Terusan Pangrango street No. 44 RT 01 RW 04, Jatibening Baru, Pondok Gede, Bekasi; March 8, 2013 mosque "Al-Misbah" belonging to Ahmadis at Terusan Pangrango street No. 44, Jatibening Baru, Pondok Gede, Bekasi, West Java was sealed again; March 19, 2013 the local government of Garut, West Java, stopped an Ahmadi mosque construction at Cipeucang, Sukawening by force; April 14, 2013 the local government of Bekasi resealed permanently the mosque "Al Misbah" at Pangrango Terusan street, Jatibening, Pondokgede, Bekasi. ${ }^{20}$

20 Tempo magazine, Jakarta 2013. 
Kiai Maman Imanulhaq, one of boards of NU, questioned the attitude of some groups that do not respect the diversity, whereas all religions teach the differences, but in frame of harmony. He asked "What kind of religion is used to burn a mosque? What kind of religion is used to chase some people away from this plural earth?"2

However, in Indonesia a law must not contradict the constitution of the state and the Pancasila, because both are the highest law of Indonesia, and also not contradict the consensus of the Indonesian people to protect equality of all Indonesians before the law. If a law contradicts both, it must be cancelled.

Another analysis that could be logic is a will of some MUI-elites to keep a bargaining position vis-à-vis the government. Moreover, the budget of the MUI comes from the national budget where the Ahmadiyah followers are contributors as tax payers. It is very ironic, because the services they got are chasing, burning their houses and mosques, even murder. Besides, the MUI likes to claim that it is an organization that can reconcile some Islamic organizations in Indonesia.

Another possibility is that the fatwa of the MUI on Ahmadiyah is an ordered one. The motive could be political, economical, or a struggle for authority. This makes sense because many people know that. Moreover, one of boards of MUI has already told that the fatwa is an order.

A foreign intervention could be also considered in this case. It is proved that the groups opposing Ahmadiyah in Indonesia are connected to the Wahabi movement, Saudi Arabia. It is well known that the Wahabi movement very much struggles to ban Ahmadiyah, they even think that Ahmadiyah followers can be chased and killed. A long time before transnational groups came to Indonesia, Ahmadis could live in harmony with other social groups especially other Islamic organizations.

The purpose of those groups is to create social conflict and disharmony among Indonesian religious followers especially Muslims. In addition, the groups that oppose Ahmadiyah can freely publish their ideas in television, newspapers, radio etc. so they can expand their influence on Indonesian Muslims. In other words, they are spreading Wahabi doctrins more intensively.

\section{The Impact of the fatwa on Ahmadi women and children}

The fatwa of the MUI on Ahmadiyah has a heavy impact on the life of Ahmadi women and children. The fatwa stigmatised Ahmadiyah as un-Islamic, heretical and misleading, even at some extent it stimulated some radical groups to act violently to Ahmadis, including their wives and children.

Ahmadi women and children have faced discrimination, alienation, violence and human rights abuses for many years. They tend to be stigmatised at school, where some teachers highlight their faith in their school report cards, several Ahmadi women had given birth prematurely after their houses had been attacked by militant

21 www.VHRmedia.com./May 8, 2008/ Kiai NU Ragukan Fatwa MUI soal Ahmadiyah. 
groups, and Ahmadis were often prevented from marrying other Muslims. ${ }^{22}$ As if there is no government effort to prevent discrimination against Ahmadi children and women. The government failed to protect its people, although its constitutional obligation.

Based on the report of The National Commission on Violence against Women, Ahmadi women besides facing human rights abuses as Ahmadi men - such as the right of freedom of faith, the right to be free from violence and discrimination, and the right to get protection - they have to face specific gender abuses such as the right to have family and to grow up the next generation, the right to gain a standard life, and women's right to their reproduction health. Ahmadi children also experienced specific abuses such as to be free from discrimination and to have an education. ${ }^{23}$

To be an Ahmadi woman is not easy. As a mother, they have the extra task to protect and upgrow their children to live as Ahmadi because their children often become the target of mockery as they are different from their friends. At the workplace they have also experienced discrimination because of their theology. Thus, Ahmadi women face a more complex social life than most women in Indonesia.

On the other side, they are very strong, they have extra bravery and extra selfendurance to live their hard life. Therefore, they are very suitable to be a model of Indonesian women who face hardship. Winy Trianita said that more than 1,000 of the members of Lajnah Ima'illah Indonesia, the Ahmadiyah women's wing, are registered as eye donors and making the organization the one with the most registered eye donors in the country. ${ }^{24}$

Lajnah Ima'illah Indonesia is the Ahmadi women's organization that promote tolerance by conducting social activities that are not only for Ahmadis but also for non-Ahmadis. By using the doctrine of pengorbanan (sacrifice), they are able to play an active role in society. ${ }^{25}$

\section{Conclusion}

From the previous discussion it can be concluded that first, Ahmadiyah is not lost, because the Ahmadiyah followers still believe in Allah, His Angels, His Books, His Messengers, and the Hereafter, as other Indonesian Muslims do. Second, the fatwa, truly, is non-binding but it bears extensive social and political impact. At some extent, it brought social conflict to Indonesian Muslims. Ahmadiyah followers became victims, their houses were burnt, some Ahmadiyah followers were chased and even killed. The Ahmadi women and children are also victims of the fatwa, because they

22 Trianita 2008.

23 The National Commission on Violence against Women, "The Report in Monitoring Human Right to Ahmadi Women, Ahmadi Women and Children: Double Discrimination Victim". Jakarta, May $22^{\text {th }}, 2008: 26-28$.

24 Trianita 2008.

25 Ibid. 
have to face discrimination, alienation, violence and human rights abuses for many years.

\section{Bibliography}

Ahmad, Mirza Bashiruddin Mahmud (1968): Invitation to Ahmadiyah. Rabwah: Ahmadiyya Muslim Foreign Misson Office.

Ișfahānī, al-Rāghib al- (2002): Mufradāt alfāz al-Qur'ān. $3^{\text {rd }}$ edition. Dimashq: Dār al-Qalām.

Khan, Muhammad Zafrulla (1978): Ahmadiyyat: the renaissance of Islam. London: Tabshir Publications.

Misrī, Abū al-Faḍl Jamal al-Dīn Muḥammad ibn Mukarram ibn Manzūr ibn 'Alī ibn Aḥmad al-Ansārī al-Afrīqī al- (1990): Lisān al-'arab. $1^{\text {st }}$ edition, vol. 11. Bayrūt: Dār Sadr.

Mudzhar, Atho: Studi Hukum Islam dengan pendekatan sosiologi; pidato pengukuhan guru besar madya ilmu sosiologi Hukum Islam, Yogyakarta, September $15^{\text {th }} 1999$.

Mudzhar, Mohammad Atho (1993): Fatwas of The Council of Indonesian Ulama: a study of Islamic legal thought in Indonesia 1975-1988. Jakarta: INIS.

National Commission of Women (2008): The report in monitoring human right to Ahmadi women, Ahmadi women and children: double discrimination victim. Jakarta, May $22^{\text {th }}$ 2008.

Rahmat, Aibdi (2007): Kesesatan dalam perspektif al-Qur'an: kajian tematik terhadap istilah "dalal" dalam al-Qur'an. Yogyakarta: Pustaka Pelajar.

Ṭabātabā' '̂̀, Sayyid Muḥammad Ḥusayn (1972): Al-mīzān fì tafsìr al-Qur'ān, vol. 6, Bayrūt: Mu' assasa al-A 'lamī.

Țabarī, al- (1978): Tafsīr al-Tabarī. Vol. 8, chapter 22. Bayrūt: Dār al-Fikr.

Tafsir Qanun Asasi, n.d., Gerakan Ahmadiyah Indonesia, n.p.

Tempo magazine, Jakarta 2013.

Trianita, Winy: The forgotten Ahmadiyah women, in: The Jakarta Post. Jakarta, February $1^{\text {st }}$, 2008.

www.google.com/Konferensi Pers Amir Jemaat Ahmadiyah Indonesia di Baitul Quran.

www.VHRmedia.com./May 8, 2008/ Kiai NU Ragukan Fatwa MUI soal Ahmadiyah 



\title{
Participation, legal discourse and constitutional rights - the 'Allah' issue in Malaysia
}

\author{
Claudia Derichs
}

\begin{abstract}
"As much as we understand the sensitivity of the issue, we are also concerned that the issue on the use of the word Allah among non-Muslims has led to severe criticisms by the international community which may reflect negatively on Malaysia's human rights record."
\end{abstract}

This statement was made by Suhakam, the state-endorsed Malaysian human rights commission, on a meeting dealing with interfaith dialogue among ASEAN countries. ${ }^{1}$ The sensitivity of the issue which is referred to in this statement harks back to a six-year old dispute over the use of the word 'Allah' in Malaysia. On the one hand, the use of the word by non-Muslims is considered inappropriate and should therefore be sanctioned. On the other hand, the use of the term is a well-known tradition of non-Muslims, particularly Christians, in Malaysia, and should be allowed. The Christian Church refers to the fact that it is, after all, the same God they pray to. They identify with their 'Allah' in the Malay language version of the Bible as Muslims do with their 'Allah' in the Qur'an. Since language and religion are extremely relevant markers of identity within Malaysian society, the issue of a right or wrong terminology bears more than a question of linguistic correctness. It expands as far as putting into question the country's Federal Constitution, which declares Islam the religion of the state but grants the right to exercise their religion to communities of other faiths. The issue thus touches upon the possibilities of citizens' political participation, the elasticity of the Federal Constitution, and the shifting normative framework of the Muslim majority society. The contestation to which the issue led raises the question: How did the dispute come about?

1 The Malaysian Insider, July 10, 2014, Asean countries should hold interfaith dialogues to resolve issues, says human rights group, http://www.themalaysianinsider.com/malaysia/article/ asean-countries-should-hold-interfaith-dialogues-to-resolve-issues-says-hum\#sthash.pIt50iAN. LG6AV6CM.dpuf (accessed Aug. 2, 2014). 


\section{Genesis of the dispute}

The Catholic publication The Herald, which is published on a weekly basis in Malaysia, has used the term 'Allah' to refer to the Christian God for years. This usage of the term follows the Malaysian (i.e. Bahasa Malaysia) translation of the Bible, named Al-Kitab, where the word 'Allah' is an integral part of the text. In 2008, the usage of the word in The Herald met severe criticism from the Home Ministry. The newspaper came under pressure when, in January 2009, the Ministry threatened to revoke the publication permit of the newspaper if the wording weren't changed. The continuation of the permit was only granted on the condition that the word 'Allah' would not appear in the publication. "The minister had prohibited the usage on grounds of national security and to avoid misunderstanding and confusion among Muslims." The Herald's official publisher, Archbishop Tan Sri Murphy Pakiam, thereupon filed an application for judicial review. The Catholic Church claimed its constitutional rights and demanded from the Malaysian government to grant these rights. While the reference for the ministry was the Printing Presses and Publications Act of 1984, the church referred to Art. 3(1) of the Malaysian Constitution, which explains about the religion of the federation and reads:

"Islam is the religion of the Federation; but other religions may be practised in peace and harmony in any part of the Federation."3

In December 2009, the High Court ruled out the ministry's prohibition. According to the said court, Art. 3 of the Constitution indeed applied. ${ }^{4}$ The Archbishop (representing the Catholic Church community) "had the constitutional right to use 'Allah' in Herald in the exercise of his right that religions other than Islam might be practised

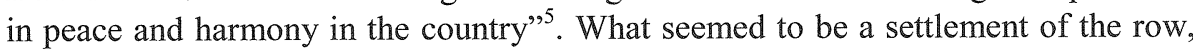
however, was not the final act. The Home Ministry filed appeal against the High Court's decision at the Court of Appeal in January 2010. In contrast to the comparatively swift decision by the High Court, the appellate Court did not push matters forward in visible way. A prolonged period of apparent inactivity on the side of the ministry and the government went by, while other parties joined in and were registered on appealing side. That is, since 2013, the Malaysian Chinese Muslim Association and six other Islamic religious councils were allowed to be parties to the ministry's intervention at the Court of Appeal. The constellation of parties at the Court of Appeal thus developed into Archbishop Murphy Pakiam vs Home Ministry, Gov-

2 The Star, Dec. 31, 2009, Court rules Herald free to use the word "Allah", http://www.thestar.com.my/story/?file=/2009/12/31/nation/20091231210348\& (accessed May. 31, 2014).

3 Legal Research Board 1999: 20.

4 There are three tiers of superior courts in the Malaysian judicial system. The highest court is the Federal Court, beneath it is the Court of Appeal, and the lowest tier is the High Court (separated into High Court in Malaya and High Court in Sabah and Sarawak).

5 Ibid. 
ernment of Malaysia, Malaysian Chinese Muslim Association plus six Islamic religious councils. ${ }^{6}$ Apart from this move, nothing seemed to happen. The Catholic Church lost patience and, in July 2013, made the Archbishop attempt to strike out the ministry's appeal. Only two months later, this led to the Court of Appeal's ruling that the use of the word 'Allah' were exclusive to Muslims. ${ }^{7}$ In January 2014, the King underscored this ruling with reference to a 1986 decree by the National Fatwa Council, saying 'Allah' and several other words were to be used by Muslims only. Furthermore, the mufti of the State of Penang (one of the Malaysian States without a Sultan who holds Islamic affairs under his jurisdiction) declared up to 40 words as forbidden to be used by non-Muslims, among them very common terms such as 'ulama', 'rasul', 'imam', or 'dakwah'. ' Public statements regarding the appellate Court's decision remain controversial, in particular with regard to the ban on using the term 'Allah' in publications or contexts other than The Herald. A raid of the Bible Society of Malaysia in the Federal Territory of Selangor caused the confiscation of over 300 copies of the holy book and yet another outcry by Malaysian Christians (January 2014).

In the East Malaysian States of Sabah and Sarawak, which joined the Federation of Malaysia in 1963, the ban of the word engendered another current of the constitutional and legal rights debate. Referring to the 1963 Malaysia Agreement, church leaders in Sabah and Sarawak stressed that both States "consented to form Malaysia in 1963 with Islam as the religion of the federation on the express condition that there will be complete freedom of religion without any hindrance placed on other religions"9. Even Prime Minister Najib Razak, holding office since 2009, had reservations in regard of a full-fledged ban of the word in Sabah and Sarawak, whereas the extremely Malay-nationalist citizens' group Perkasa demanded that the two States "should be educated" on the Court of Appeal's ruling that "the word 'Allah' is not an integral part of the Christian faith"10.

6 See Says channels, Infographic: Timeline of the Allah Case Starting form 2009, http://says.com/my/news/the-allah-ban-in-malaysia-latest-updates-and-timeline-of-events (accessed June 14, 2014)

7 The Malay Mail, Oct. 14, 2013, Court of Appeal quashes 'Allah' judgement, http://www.themalaymailonline.com/malaysia/article/court-of-appeal-quashes-allah-judgment (accessed June 14, 2014).

8 New Straits Times, Jan. 11, 2014, Penang mufti outlaws 40 words to non-Muslims, http://www2.nst.com.my/nation/general/penang-mufti-outlaws-40-words-to-non-muslims1.459685 (accessed May 31, 2014)

9 Religious Liberty Watch, Oct. 11, 2013, The Native Bumiputera Christians Have Spoken: Betray Not Our Freedom of Religion Guaranteed by the Malaysia Agreement, http://libertysentinel.wordpress.com/2013/10/11/the-native-bumiputera-christians-have-spokenbetray-not-our-freedom-of-religion-guaranteed-by-the-malaysia-agreement/ (accessed Nov. 14, 2013).

10 The Malay Mail, Oct. 14, 2013, Court of Appeal quashes 'Allah' judgement, http://www.themalaymailonline.com/malaysia/article/court-of-appeal-quashes-allah-judgment (accessed June 14, 2014; italics added by author). 
While the Catholic Church claimed its right to appeal against the appellate Court's decision, the Federal Court - the highest court in the three-tier structure of superior courts - refused to grant this right. Although the Malaysian Bar Council explicitly regretted the Federal Court's decision to refuse the "application for leave [of the Archbishop; C.D.] to appeal against the Court of Appeal decision" because of wider implications for Malaysian minority rights, the decision did not change. ${ }^{11}$

\section{The wider scope}

Putting the Court of Appeal's decision as a matter of fact aside, what is more striking is the genesis and direction of the reasoning behind this decision. That the word "Allah' was "not an integral part of the faith in Christianity", it could "cause confusion in the community", and that the ban on the use did "not impugn on the Church's constitutional rights" 13 adds a new tone to the melody of religious pluralism in Malaysia. The declaration that the use of the term 'Allah' by non-Muslims was likely to cause "confusion" among Muslims - provided they are referred to by 'community' - is a severe issue. Even more alarming is the declaration that the continued attempts of the Catholic Church to protest the ruling is a security issue causing disharmony and disturbing the social order of Malaysian society - an opinion brought forward by the home minister. ${ }^{14}$ Or from another angle: The government's justifying the ban "on grounds of national security and to avoid misunderstanding and confusion" $" 15$, hints at the securitization of a purely civil and religious issue. The official reasoning is that if the use of the word 'Allah' is not limited to Muslims, it will cause public disorder. Hence the Malaysian Catholic community should be restrained, despite Art. 3 and other provisions in the Federal Constitution, for the sake of 'public order and harmony'.

Australian sociologist Clive Kessler has analysed the apparently illogic argumentation of the proponents of a ban of the word's use in a four-piece contribution

11 The Malaysian Bar, June 24, 2014, Bar Council: 'Herald' decision may be binding on other publications,

http://www.malaysianbar.org.my/legal/general_news/bar_council_herald_decision_may_be_bin ding_on_other_publications.html (accessed Jully 1, 2014)

12 BBC News Asia, Oct. 14, 2013, Malaysia court rules non-Muslims cannot use 'Allah', http://www.bbc.com/news/world-asia-24516181 (accessed Nov. 11, 2013)

13 The Malay Mail, Oct. 14, 2013, Court of Appeal quashes 'Allah' judgement, http://www.themalaymailonline.com/malaysia/article/court-of-appeal-quashes-allah-judgment (accessed June 14, 2014; italics added by author)

14 The Malay Mail, Nov. 17, 2013, Utusan: 'Allah' row now a national security issue, http://www.themalaymailonline.com/malaysia/article/utusan-allah-row-now-a-nationalsecurity-issue (accessed Nov. 18, 2013)

15 Sky News, Oct. 14, 2013, Malaysia: 'Allah' word banned for non-Muslims, http://news.sky.com/story/1154300/malaysia-allah-word-banned-for-non-muslims (accessed Oct. 31,2013 ) 
to the online publication New Mandala. Kessler relates the issue and the legal discourse surrounding it to the principle of Ketuanan Melayu oder 'Malay supremacy', which is upheld by activists of Perkasa and other groups committed to privileges and special rights for ethnic Malays. In Kessler's view, the 'Allah' debate shows that the ideology of Ketuanan Melayu seeks to set aside the liberal democratic understanding of the Federal Constitution and to replace it with one that is grounded in an exclusionary "blood and soil" version of Malay nationalism. ${ }^{16}$

This setting aside of a liberal democratic understanding of the Constitution did not come about inadvertently or by chance. The decline of this kind of understanding went side by side with a growing prominence of Islamic jurisprudence, an increasing inclination to regard Malaysia an Islamic state, and the jargon of Malay supremacy. If in this atmosphere, Kessler figures, "principled legalism has no strong roots in the sentiments of the nation's people", "the discourse and practice of the law and its professional exponents these days have no widespread public support"17. Even worse: They have forfeited a good deal of their credibility, and the politicians for their own reasons have been happy to encourage that decline in confidence. More fatefully, for much more far-reaching ideological reasons, they have unleashed, and continue to back and drive, the tandem forces of Malay supremacist assertion and Islamist legalism that are placing what has long been understood as the practice and discourse of the law under siege. ${ }^{18}$

The argument is strong and goes back to several decades of observation and scholarly analysis of Malaysian social and political affairs. The 'secular' legal discourse, once dominant in its impact and status, has become not only accompanied but besieged by two other influential and powerful discursive currents. "These, of course, are the discourse of Islam and the discourse of Malay culture, identity, received history and nationalism."19 Although Kessler does not speak of a 'secular' legal discourse, we may relate to this term in order to distinguish it from the discourse of Islam. The (secular) legal discourse, Kessler states, "is subject to challenge from, and through recourse including official and also less formal government recourse to" the discourse of Islam, and the Ketuanan Melayu/Malay nationalist discourse. $^{20}$

16 Kessler, Clive, Part 3: The vulnerability of Malaysia's legal discourse; in: New Mandala, July 23, 2014, http://asiapacific.anu.edu.au/newmandala/2014/07/23/the-vulnerability-of-malaysiaslegal-discourse/ (accessed July 30, 2014)

17 Kessler, Clive, Part 4: The dhimmi and an old new "rationale"; in: New Mandala, July 24, 2014, http://asiapacific.anu.edu.au/newmandala/2014/07/24/the-dhimmi-and-an-old-newrationale/ (accessed July 30, 2014)

18 Ibid.

19 Kessler, Clive, Part 1: Malaysia: A discourse-impoverished society; in: New Mandala, July 21, 2014 , http://asiapacific.anu.edu.au/newmandala/2014/07/21/malaysia-a-discourse-impoverishedsociety/ (accessed July 30, 2014)

20 Ibid. 
The feeling of "Islam's legal advance" 21 and its gradual challenge to the secular courts' authority is shared by many people in Malaysia, particularly those who have gained first-hand experience with decisions from official sides. A recurring issue in this regard is the one of child custody. When, for instance, the husband of a nonMuslim couple converts to Islam and subsequently also converts their children, it is almost impossible for the non-converted wife to get custody of these children in case of a separation. The New York Times featured one recent a case of the non-Muslim citizen Subramaniam and commented:

In Subramaniam's custody battle, and another similar case, Malaysia's national police chief, Khalid Abu Bakar, has declined to act on judges' orders for children to be returned to their mothers, citing competing orders from the civil courts and state shariah courts. His stance has been backed by the home minister.

The paper traces the politicians' and activists' "pushing for Islam to play a bigger role in society" back to the general elections of May 2013, which, it says, "further polarized the nation and left the government more reliant on Malay and Islamic conservatives" ${ }^{22}$. This direct link to the elections may be true to a certain extent, but the ground for this tendency to take roots was laid well before 2013. And it has, presumably, helped the Court of Appeal to convey the reasoning that a violation of the Constitution's Art. 3 - as perceived by proponents of a liberal democratic understanding - is no such violation. This reasoning is logic if the clause that religious faith communities other than Muslim may practice their religion 'in peace and harmony' is understood to refer - in this logic - to peace and harmony from the perspective of the Muslim majority society. Peace and harmony are achieved as long as the Muslim community is capable of guaranteeing that all religious communities can live together peacefully. Hence, non-Muslim religious communities are to be protected by the Muslim community, and with such status shall comply with what the latter considers conducive to the preservation of peace and harmony. If this logic were to be applied to the interpretation of the Malaysian Constitution, the Islamic legal discourse takes precedence over the 'secular' legal discourse. The "Common Law tradition, "the discourse of constitutional legality," says Kessler, "is in a beleaguered and precarious situation." 23

21 The New York Times, Asia Pacific, July 12, 2014, In Malaysia, Islam's Legal Advance Divides Families and Nation. http://www.nytimes.com/reuters/2014/07/12/world/asia/12reutersmalaysia-

islam.html?hp\&action=click\&pgtype=Homepage \&version $=$ WireFeed\&module=pocketregion\&region=pocket-region\&WT.nav=pocket-region\&_r=0 (accessed July 14, 2014).

22 Ibid. - A scholarly work referring to the famous case of Lina Joy is offered in Lee, Lulian C. H. (2010), Islamization and Activism in Malaysia. Singapore: ISEAS, $62-73$ (= Capter 4: Conflict and Jurisdiction: Civil versus Syariah Law)

23 Kessler, Part 4, op cit. 
What has been analysed by the well-known Australian scholar Kessler is a noteworthy diagnosis of contemporary Malaysian society. And it points to the political elite's reluctance to defend a liberal democratic understanding of the Constitution. It appears as if the political elite including the current government were much more worried about 'peace and harmony' within the Muslim community than about violation and severe restriction of minority rights. The normative frame of reference has shifted from an equality-based interpretation of the Federal Constitution to an increasingly dominant sharia-inclined jurisprudence. Cases of a "conflict of jurisdiction" have become more frequent than a few decades ago and evolve around Arts. 3 and 11 of the Federal Constitution ${ }^{24}$ on the one hand and Islamic jurisdiction on the other. ${ }^{25}$

While Art. 3 of the Constitution (plus the 1963 Malaysia Agreement on the case of Sabah and Sarawak) take center stage in the constitutional legal debate on minority rights, Art. 153 refers to the special rights of ethnic Malays. We will concentrate on these two articles and discuss the Court of Appeal's decision from the perspective of its repercussions for an equality-based, democratic political participation of all citizens. Against the backdrop of Arts. 3 and 153, the guiding question is what it means to be restricted, as a citizen, in the use of certain vocabulary of the national language, and (from a Muslim's vantage point) to be declared a citizen who will all of a sudden get 'confused' by something that has been around for ages.

\section{What constitution for whom?}

The ethnic and cultural dimension of codified norms is obvious in the Constitution of Malaysia, albeit not always expressed explicitly in its respective articles. ${ }^{26}$ Malaysian politics has always been determined and performed along ethnic communal lines. The institutional manifestation of the administration of multiethnic relations is quite unique in its kind and merits a closer look, particularly with regard to the perceived dominance of an Islamic and Malay nationalist discourse in contemporary Malaysian society. On the one hand, Malaysia's political stability over decades is remarkable and has been pointed out by many scholars and comparativists. On the other hand, communal tension and articulated worries about violations of the constitution have increased in recent years. They have not come about suddenly, but as a result of, as we have argued elsewhere,

24 Art. 3 refers to the Religion of the Federation, Art. 11 to the Freedom of Religion. Art. 11 of the Federal Constitution is only concerned with individual persons' rights to profess and practice their religion, thus not addressing whole religious communities.

25 Cf. Lee 2010: 62-73.

26 Parts of this section are taken from Derichs, Claudia, Constitutional Rights in Multiethnic States - The Case of Malaysia, in: Ehlers, Dirk/Henning Glaser/Kittisak Prokati (eds.): Constitutionalism and Good Governance: Eastern and Western Perspectives. Baden-Baden: Nomos 2014, 255-279. 
- a rather authoritarian policy implementation and

- the 'hijacking' of control over law and order by one segment of society. ${ }^{27}$

The constitution is not a lopsided institution. It nurtures indeed confidence in a 'plural society' vision. It does not preclude, for instance, the possibility of non-Malay rule through the legislative and executive institutions of the federation - in the States as well as on the federal level. In political reality, however, a non-Malay ruler is inacceptable. ${ }^{28}$ 'Malay dominance' and the preservation of 'Malayness' are recognized in politics and society; Malay hegemony is firmly consolidated in the political world. But the commitment to a 'plural society' concept is nevertheless allowed for by the Constitution. The dualism of the Constitution - in the sense of its dual commitment to the features of Malay-Muslim primacy and to the plural society concept - reflects a special attention to one particular ethnic community in the multiethnic state, while recognizing the reality of ethnic pluralism. In the Constitution, the effort to cater to both requirements condenses in a unique provision of 'special rights' for Malays in exchange for a citizenship status for non-Malays - an inter-ethnic 'social contract'.

The primacy of Malays and 'natives' (i.e. non-Malay indigenous communities) is expressed in Art. 153 of the Constitution. Through this article, the Constitution assures Malays and natives of Sabah and Sarawak, who altogether became subsumed under the term bumiputera, prior recognition in several respects. The monarch (King or Agong) is responsible for safeguarding the special position of Malays and natives, but also for safeguarding "the legitimate interests of other communities". ${ }^{29}$ All provisions mentioned in the Art. 153, for instance the ensurance of positions in the public service (national level), of scholarships or other educational privileges, of permits or licences for the operation of trade or business when required by federal law, can be determined "as he $[=$ monarch; C.D. $]$ may deem reasonable"30. In political practice, the meaning of the term 'reasonable' is rather defined by government and bureaucracy than by the monarch. The content of Art. 153 was initially meant to reconcile an ethnic primacy demand with a plural society vision, but it has become strongly biased towards a Malay supremacy. This is one of the background features to the debate about Art. 3 (1), which relates to the rights of religious minority groups.

As cited above, Art. 3(1) grants the practise of their religion to communities other than Muslims. The Malaysia Agreement of 1963, which is the main source in relation to the same issue in the case of Sabah and Sarawak, contains the wording "freedom of religion without any hindrance placed on other religions." For several decades after independence - and after 1963 respectively - the prevailing common

27 Ibid.: p. 256.

28 The discussion of a non-Malay prime minister gained momentum after the elections of 2008 . The opposition coalition Pakatan Rakyat, which is composed of Malay and non-Malay parties alike, agreed on a Malay prime minister in case this issue came up at some point in future.

29 Federal Constitution, Art. 153(1).

30 Federal Constitution, Art. $153(2 ; 3 ; 5 ; 8 \mathrm{~A})$. 
understanding of these clauses seemed to be clear: Non-Muslims are free to practice their religion as long as they do it peacefully and harmoniously. Accordingly, the Catholic Church in Malaysia turned to pray in the language of the Federation or the national language, i.e. Bahasa Malaysia, and hence refer to 'Allah' and not to God, for God is not the Bahasa Malaysia term. When the Court of Appeal has judged that the use of the Word 'Allah' is not an integral part of the faith in Christianity, and the ban does not imply an impugnment on the Church's constitutional rights, the prevailing common understanding seems to have changed. Practicing one's religion as a citizen of a state in the language of the state would - conventionally - imply to use the terms that are recognised to be part of the national language. When the right to use such terms is restricted, it consequently means that communication in the national language is an only partially granted right for some citizens, while a fully granted one for others. The practise of the faith in the language of the nation is not equally guaranteed anymore. However, the appellate Court has not dealt with the question of practising faith in the national language. It has (merely) ruled that a term such as 'Allah' is not an integral part of the faith in Christianity. Accordingly and in this logic, a proper practice of the faith is still possible since the word is not needed in this practise. Hence the explanation of the Court of Appeal indeed does not touch upon the right of religious minority groups to practise their faith - and consequently does not violate the right granted in Art. 3 of the Federal Constitution. The question remains: How did the Court of Appeal get to know what is an integral part of the faith and what is not? We cannot trace the answer to this question here. Rather, the crucial point to look at is how the ruling of the court can serve to draw the conclusion that the use of the word 'Allah' is exclusive to Muslims in Malaysia. For the judgement is not interpreted as: 'Allah' is not an integral part of your faith, but still you may use it since it is part of our national language. Conversely, the interpretation suggests: Although it is part of our national language, you may not use it since it is not an integral part of your faith. How does this reverse conclusion come about?

As lawyer and human rights activist Zarizana Abdul Aziz has mentioned, Art. 3 of the constitution says that Islam is the religion of the Federation of Malaysia. This was for a long time understood as the proof that Malaysia is not an Islamic state. However, it has become increasingly understood nowadays as the proof that it is one. ${ }^{31}$ Observers like Zarizana relate this phenomenon to a growing appropriation of the right of definition by the state. The Malaysian state reserves for itself almost exclusively the right to define what is Islam and who is a Muslim. Among other measures,

$[\mathrm{t}]$ he government replaced the tremendous diversity in religious interpretation with a codified version of state-enforced "Islamic law". Government-appointed Muftis are empowered to issue fatwas that are "binding on every Muslim resident". Fatwas carry the force of law and are backed by the full

31 Zarizana Abdul Aziz, public lecture to the Conference "Europe and Asia - Democracy in Entangled Modernities", Marburg, Jan. 18-19, 2013. 
power of the Malaysian state. The Syariah Criminal Offences Act and parallel state-level enactments further consolidate this monopoly on religious interpretation. $^{32}$

Tamir Moustafa calls this an authoritarian reformulation of the Islamic legal tradition. ${ }^{33}$ The 'Allah' case may be seen as yet another element of this development. The state - by way of interpreting the ruling of its judicial branch - defines the term 'Allah' as one that is used exclusively by Muslims. The understanding that the term was considered part of the Bahasa Malaysia vocabulary and therefore meant to be used by all Malaysian citizens has faded in the climate of an ever stronger belief in certain prerogatives for Malay Muslims (Ketuanan Melayu).

This brings us back to Art. 153 of the Constitution. It is laid out there that the King is responsible for safeguarding the special position of Malays and natives. When the Court of Appeal rules that the use of the term 'Allah' by non-Muslims (i.e. predominantly non-Malays because the Constitution stipulates that all Malays are Muslims) could cause confusion in the community of Muslims, then it is not surprising that the King is eager to prevent such confusion. The King's affirmation of the court's decision with reference to a 1986 decree by the National Fatwa Council in January 2014 could almost be expected. But again, there is a flipside to the coin when we take the status of a citizen into account. What makes a court and a monarch look at the mature citizens of a progressive, modern and independent state as 'confused' beings? While the word 'Allah' was used by Catholics in Malaysia for decades without making their fellow citizens in the Muslim community confused, those same Muslim citizens are now suspicious of getting confused. Their ability to distinguish between 'Allah' in a Christian context and 'Allah' in a Muslim context has come into doubt. This renders the understanding of 'safeguarding' biased towards the understanding of court and king as (legal) guardians of Malaysia's Muslim citizens. The supremacy (ketuanan) that is longed for ultimately ends up in an alleged loss of the intellectual capability as a citizen to distinguish between Christian and Muslim practises.

The Malaysian Muslim community has experienced the power of definitions, interpretations and understandings which acquire legal or quasi-legal binding in other regards, too. And it seems that similar questions are raised in view of intrareligious issues of interpretation. Who has the right to declare a particular interpretation to be the one-and-only valid source for legal pronouncements? The co-founder of the Malaysian Muslim women's organisation Sisters-in-Islam (SIS) Zainah Anwar recalls:

32 Tamir Moustafa, Is Malaysia an Islamic State?, in: New Mandala, July 16, 2014, http://asiapacific.anu.edu.au/newmandala/2014/07/16/is-malaysia-an-islamic-state/ (accessed August 1, 2014).

33 Ibid. 
WHO decides which interpretation, which juristic opinion, which hadith, which traditional practice would prevail and be the source of codified law in this modern world, to govern our private and public lives and punish us if we fail to abide, and which would fall by the wayside? On what basis is that decision made? Whose interests are protected and whose interests are denied? ${ }^{34}$

The same questions can be asked from a political point of view. From a liberal democratic point of view, for instance, both these peculiar interpretations of the clauses in the Federal Constitution (Art. 3(1) and Art. 153 (1)) discussed above run counter to the concept of a mature citizen who is entitled to political participation in his or her state. They run counter because a citizen who is aware of his or her belonging to a religious minority would nonetheless request the permit to use the national language - within and apart from the practice of one's faith. And they run counter because a citizen who is aware of his or her belonging to a religious majority and being intellectually capable to a certain extent so as most probably not getting confused when the same word is used by different people.

\section{Concluding thoughts}

The Malaysian government's compliance with the Court of Appeal's and the Federal Court's decisions stretches out to the question of citizens' political participation. It also tells us about the elasticity of the Constitution and the shifting normative framework of the Muslim majority society. Political participation of a state's citizen entails the possibility to articulate interests and be part of political communication equal to one's fellow citizens. The ruling of the Court of Appeal in Malaysia was followed by various decrees on the State level which prohibit non-Muslims from using very common terms (e.g. the 40 words list in Penang). In a state where religion and politics are so intertwined as in Malaysia, articulating an opinion on a religio-political matter without using certain matching 'technical' terms is difficult. It restricts the citizen's capability to express his or her thoughts. For a citizen who is entitled to make full use of the vocabulary of the national language, participation in political discourses is easier. However, when citizens are suspect of getting confused easily and have to be safeguarded by an authority in order to be protected from confusion, their recognition as (intellectually) mature persons is at stake, too.

The effectiveness of the legal jurisdiction in Malaysia is clearly demonstrated by the ruling on the 'Allah' issue. From a liberal democratic point of view, this is a positive feature. At the same time, Malaysians have noticed that the Constitution is a remarkably elastic institution which allows for legal interpretations that would have been unthinkable a few decades ago. Consequently, the Federal Constitution is not a guarantor for certain rights, but an assembly of clauses that are open to very polar-

34 Anwar 2013: 30 . 
izing, contrasting interpretations. When particular currents of opinion become dominant over time, it may happen, as Clive Kessler put it, that the practice and discourse of law are put under siege. Minority rights are relegated to second rank and supremacy rights are pushed to the center.

This shift in the priority of rights is not a sudden effect of some temporary discursive mood. It has constantly grown and is groomed by Malay-nationalist groups as well as Islamist forces. Despite the Prime Minister's national and international campaigning for a "Global Movements of Moderates" (GMM) $)^{35}$, many facts on the ground suggest that the normative frame of reference in Malaysia has transformed from a plural society towards a hegemonic Malay-Muslim orientation.

\section{References}

Anwar, Zainah (2013): What Islam, who's Islam? The struggle for women's rights to equality and justice in Muslim contexts, in: Berita Newsletter: 25-36.

Lee, Lulian C. H. (2010): Islamization and activism in Malaysia. Singapore: ISEAS, 62-73.

Derichs, Claudia (2014): Constitutional rights in multiethnic states - The case of Malaysia. In:

Ehlers, Dirk/Henning Glaser/Kittisak Prokati (eds.): Constitutionalism and good governance: Eastern and Western perspectives. Baden-Baden: Nomos, 255-279.

Legal Research Board (Comp. 1999): Laws of Malaysia. Federal Constitution. Kuala Lumpur: International Law Book Series.

\section{Internet:}

BBC News Asia, http://www.bbc.com/news

Global Movement of Moderates, http://www.gmomf.org/

New Mandala, http://asiapacific.anu.edu.au/newmandala

New Straits Times, http://www2.nst.com.my

Religious Liberty Watch, http://libertysentinel.wordpress.com

SAYS Malaysia, http://www.says.com/my

Sky News, http://news.sky.com/

The Malaysian Bar, http://www.malaysianbar.org.my

The Malaysian Insider, http://www.themalaysianinsider.com

The Malay Mail, http://www.themalaymailonline.com

The New York Times, http://www.nytimes.com/reuters

The Star, http://www.thestar.com.my

35 See http://www.gmomf.org/ 


\title{
Translational Turn and international law: gender discourses in the Islamic Republic of Iran
}

\author{
Irene Schneider
}

\section{Introduction to the field}

In this article I analyze the discourses on the implementation of international human rights in Iran in a certain period, thereby focusing especially on the concept of gender-(in)equality. As examples I selected two well known female jurists, Farība 'Alāsvand and Shahīndokht Mawlāverdī as representatives of contradictory positions with regard to gender-equality and the implementation of international human rights.

International Law and especially international covenants claim universality but have to be transferred to the national legal contexts of the nation states ${ }^{1}$. Dealing with the implementation of international covenants into the national legal context jurists of international law often speak of the "migration" of the concept of (human) rights ${ }^{2}$, thereby concentrating on the process of "traveling" or "coming to" the nation state. In their book The Power of Human Rights, Risse/Sikkink (1999) investigate the general conditions under which international norms are implemented in states. They argue that international human rights norms challenge state rule over society and national sovereignty, are well institutionalized in international regimes and organizations, and are contested and compete with other principled (sic! IS) ideas. ${ }^{3}$ They argue that the diffusion of international norms in the area of human rights depends crucially on the establishment and the sustainability of networks among domestic and transnational actors especially NGOs (Non-Governmental Organizations) and INGOs (international NGOs) that manage to link up with international regimes to "alert Western public opinion and Western government" . They challenge norm-violating governments by creating a transnational structure to pressure such regimes "from above" and "from below". Risse/Sikkink call the process by which

1 Risse\&Sikkink 1999; Ali 2000.

2 Baer 2011.

3 Risse\&Sikkink 1999: 4.

4 Ibid.: 5 . 
international norms are internalized and implemented domestically a process of "socialization", and use a "spiral model" to illustrate its stages which are:

1. Repression of human rights activities.

2. Denial: Repressive state denies the validity of human rights norms.

3. Tactical concessions: Concessions to the human rights network, reduced room for maneuver against human rights.

4. Prescriptive status: State accepts international norms, ratifies treaties and institutionalizes norms domestically.

5. Rule-consistent behavior. ${ }^{6}$

In phase 1 domestic-societal opposition is too weak or too oppressed to present a significant challenge to the government. In phase 2 the norm-violating state is put on the international agenda of the human rights networks. This serves to raise the level of international public attention toward the "target state". If this continues and escalates, the norm-violating state seeks cosmetic changes to pacify international criticism in phase 3 . Phase 4 sees the actors involved regularly refer to human rights norms to describe and comment on their own behavior and that of others. It is a necessary step toward, but not identical with the next phase, phase 5: rule-consistent behavior. Governments might accept the validity of human rights norms, but still continue to torture prisoners or detain people without trial, etc. ${ }^{7}$

This model ${ }^{8}$ is developed by the authors as a "theory of the stages and mechanisms through which international norms can lead to changes in behavior" ${ }^{\prime 9}$ but the authors do not assume an evolutionary or automatic progress. Instead they suggest that regimes might return to oppression after some tactical concessions in phase 3 when international pressures have decreased. States might not care about transnational and international opposition concerning their behavior. ${ }^{10}$ They argue that countries that resist are not economically weak per se but do not care about their international image. Furthermore, Risse/Sikkink are well aware - as seen on the quotation above - that international human rights norms "compete with other principled ideas" $" 11$ but they do not elaborate on this.

It is here that I would like to start with my analyses: What are the conditions under which human rights Conventions, in this case the CEDAW (Convention on the Elimination of all Forms of Discrimination against Women, 1979) are adopted in Iran? How is this process connected to the dominance of "other principled ideas"? What are these principled ideas and what is their role? As an example I take the discussion on human rights and the concept of gender and gender-roles, the question of gender-equality and gender-hierarchy in the Islamic Republic of Iran which

\footnotetext{
5 Risse\&Sikking 1999: 5.

6 Ibid.: 20.

7 Ibid.: $19-35$.

8 Ibid.: 18 .

9 Ibid.: 2 .

10 Ibid.: 34 .

11 Ibid.: 4.
} 
evolved around 2004-2006 when the ratification of the CEDAW was under discussion in Iran and than rejected. I do not focus on the role of NGOs and INGOs in this article. I have analyzed the discourse and practices of civil society in connection with the debate of the new Family Draft Law in 2008 in Iran elsewhere. ${ }^{12}$ The discourse in the public sphere in 2008 , however, did not refer to international conventions, e.g. the CEDAW. On the contrary, it seemed to be taboo, whereas arguments pointing to Islamic law, statutory Iranian law, society and its evolution and the necessities of a modern state were widely used. ${ }^{13}$

Iran is one of the few states in the world that has not yet ratified the CEDAW, unlike the majority of Muslim states. Most Muslim states ratified the CEDAW with reservations, often referring to Islam or religious law, sharia. ${ }^{14}$ The CEDAW was accepted by the Iranian Parliament, but rejected on 1/5/1382 /August $7^{\text {th }} 2003$ by the Council of Guardians, an organ which determines whether laws passed by the Parliament are "Islamic"or not. The matter was then referred to the Expediency Council, where to date (July 2014) it is still awaiting a final verdict. According to Osanloo $^{15}$ there was a lively public debate on the CEDAW in 2003 prior to the decision by the Council of Guardians. At this time the sources of tension between Islamic principles, human rights, and specific discriminatory practices were subjects of constant conversation among advocates. ${ }^{16}$ More often than not, pious Muslim women's rights advocates spoke of the patriarchal "misapplications" of Islam. These tensions were not seen as inherent in Islam but in the discriminatory manner in which these ideas had been mobilized. The public debate eventually died down and in 2008 it was not considered constructive or politically acceptable to mention the CEDAW or more generally international human rights in discussions about the Family Draft Law. The CEDAW was dealt with at a scholarly level, but not in public discourse. 'Alāsvand and Mawlāverdī are, on the other hand, representatives of a broader discussion not on the CEDAW but more generally on related gender-concepts. An interesting development can be seen in the fact that both of them were given high political positions in the Islamic Republic after the election of Hasan Rohani as President in June 2013.

12 Schneider 2010.

13 This is different in other Muslim states where international covenants and especially the CEDAW are often referred to not only by actors of the civil society but also by the state itself, e.g. the king of Morocco; see: for Morocco Buskens 2003, for Palestine see Welchman 2003.

14 For the text of the Convention, the state parties and the reservations see: http://www.un.org/ womenwatch/daw/cedaw/, accessed on February 4, 2014.

15 Osanloo 2009.

16 Ibid.: $188-191$. 


\section{Aims, theories, method of research}

The question that arises is how the regulations of international law are exactly integrated into the national legislation or, with regard to Iran, how the discussion about the CEDAW and the connected concepts and terminology of gender-equality continued even after ratification was denied. My hypothesis is that human rights can only be incorporated through actors within local issues and realms of consciousness. Given their political and scientific role, the two scholars I selected are representatives of public discourse in the Islamic Republic.

The term "translation" is used when describing the discussion process of the CEDAW with reference to Doris Bachmann-Medick's recently-published article "Human Rights as a Problem of Translation" (Menschenrechte als Übersetzungsproblem). She speaks out for a "Translational Turn"17, arguing that translation refers both to a category of practice as well as to an epistemological category of analysis. In cultural studies, "translation" as a category of analysis is understood to be the relaying or negotiation of a concept; a semantic shift or transformation through its transfer into a new context. ${ }^{18}$ Human rights concepts and conventions etc. are "translated" into the foreign cultural context ${ }^{19}$ and it is this process of translation which needs to be focused on. The question arises how certain terms and concepts are expressed in another language whereby the chosen terms or "translations" carry perhaps a different cultural understanding and connotation. In such a discursive process many different "translations" occur in the sense of cultural interpretations and connections to different understandings. Translations are understood to be complex cultural processes that underlie a methodic inter-culturalism. Thus the harmonizing image of translation as bridge-building between cultures surely must be abandoned; negotiating of differences is the main task in this context. ${ }^{20}$ Chakrabarty sees translation as displacement. ${ }^{21}$ It is therefore necessary to concretely focus on the actors and tangible realms of translation and on the used terminology. ${ }^{22}$

This is what will be done in this article: focusing on concrete speech, the terminology and concept of gender (in)equality or gender roles (3.2), the concept of feminism (3.3), as well as the role of religion (Islam) and, more exactly, of religious law (3.4). Strategic arguments presented in favour of or against the ratification of the CEDAW are analyzed as well (3.5).

17 Surely this "turn" is not completely "new". For similar discussions see: Najmabadi 1998, 2006: 13; Merry 2006: 102, 177; Abu-Lughod 2009: 91-97. If I opt here fort he implementation of the "translational turn" it is more for bringing into conscious this important aspect of concentration on the language and terminology as closely connected to cultural concepts.

18 Bachmann-Medick 2012: 331.

19 Ibid.: 336.

20 Ibid.: 332.

21 quoted in: Ibid.: 341

22 Ibid.: 334. 
Bachmann-Medick compares the Universal Declaration of Human Rights (UDHR 1948) to the Islamic Declaration of Human Rights of Cairo (IDHR 1990) and asks what translation exactly means and where translation becomes a revision of the letter and the spirit of the Universal Declaration of Human Rights. The IDHR is, according to her, a revision of the text and the spirit of the UDHR. ${ }^{23}$ Thus the relevant question is: When can we speak of a translation into a different cultural context and when do we have to see this outcome of the discussion as a revision of the letter and spirit of the original text?

The questions discussed so far refer to the "arrival" of human rights instruments in another cultural context and the question of how these "translations" take place. There is another powerful discourse criticizing the application from a mostly political point of view. This will become evident from 'Alāsvand's arguments but it is also a topic in the feministic research on the Middle East mainly centered in the US. Regarding the Arab Human Development Report 2005, which has references to international covenants, especially the CEDAW, Lila Abu-Lughod harshly criticizes the "pathologizing" of the Middle East in painting a negative picture of women's rights and lives there. ${ }^{24}$ She fears that the report focusing on the Arab world could be appropriated in negative ways, and that it attributes a significant role to the Arabic and Islamic culture in creating a dichotomy of modern - traditional and, with respect to gender-roles, sees "the" Islamic culture as a culture of gender-inequality. ${ }^{25}$ The transnationalism of international concepts expressed in language, a particular "international" or "transnational" dialect which frames the rights and transports certain assumptions and politics is also criticized by her. ${ }^{26}$ Abu-Lughod is aware that a patriarchal family has "its problems" but does not discuss its role and the connected gender-concepts in detail. Instead she concentrates more on political oppression than on gender oppression. ${ }^{27}$ She blames the three keys to women's empowerment in the report: education, employment, and individual rights as imposed by a hegemonic Western discourse, and would not see "individualization" as a way to empower women to leave this patriarchal family structure behind. She gives no clue how these hierarchical gender relations should be reduced or whether gender equality is a desirable aim at all. ${ }^{28}$ She is, as will become evident, quite in accordance with the very conservative Iranian scholar 'Alāsvand who rejects the CEDAW equally because it is in favor of individual rights for males and females, seeing this as endangering the family structure. Abu-Lughod somehow romanticizes Middle Eastern grand-familystructures - which, by the way, are on the retreat in the urban areas of the Middle East much as anywhere else in globalized modernity. Accusing the report of presenting an ideological and unhistorical family assessment, she then herself con-

23 Bachmann-Medick 2012, 343.

24 Abu-Lughod 2009: 98.

25 Ibid.: 85 .

26 Ibid.: 83 .

27 Ibid.: 90 .

28 Abu-Lughod 2009: 87, 90. 
structs "the family" with whom she was acquainted during her research in rural Egypt, thereby ignoring the plurality of family forms and structures in the Middle East (as well as in Europe). Instead she points to the political oppression of women in the Middle East, which surely exists. Important within the context of this article is her approach to the language, which she calls a "dialect of (neo)liberalism". She argues that the particular hegemonic language used for the report has serious consequences not only for the ways in which it frames problems, but also in the ways in which it proposes solutions. ${ }^{29}$

When the conclusion of the report calls for empowerment and overcoming "the legacy of backwardness" by "eliminating all forms of discrimination against women in Arab society", it admits freely that the borrowing here of exact language from CEDAW "is not accidental". It is meant as "a reminder that this national objective is, at the same time, an international objective that humanity as a whole seeks to achieve. It is also an Arab commitment towards the international community". ${ }^{30}$

Her critique of this international language may be correct but Abu-Lughod overlooks that these terms and concepts are not so much imposed - not at all in Iran as will become evident - but are integrated into the cultural context in a complex process of cultural "translations".

\section{Discourse about the CEDAW}

Article 2 in the CEDAW is the basis for the discussion about equality:

Article 2

States Parties condemn discrimination against women in all its forms, agree to pursue by all appropriate means and without delay a policy of eliminating discrimination against women and, to this end, undertake:

(a) To embody the principle of the equality of men and women in their national constitutions or other appropriate legislation if not yet incorporated therein and to ensure, through law and other appropriate means, the practical realization of this principle; ${ }^{31}$

The "principle of the equality between men and women" reads in the Arabic translation (there is no official Persian translation): mabda' al-musāwāt bayn al-rajul wa al-mar'a, musāwwāt having the same Arabic root as tasāvi $(\mathrm{s}-\mathrm{w}-\mathrm{y})$ which is, as will be shown, used in the Persian translation. ${ }^{32}$

29 Ibid.: 91.

30 Ibid.: 94.

31 See: http://www.un.org/womenwatch/daw/cedaw/text/eConvention.htm, accessed on July 12, 2014.

32 See the Arabic translation: http:/www.un.org/womenwatch/daw/cedaw/text/0360793A.pdf, 
The Council of Guardians rejected the CEDAW, which had been accepted before by the Parliament, pointing to Article 28 , no $2^{33}$ a general incompatibility with the aims (and?) intentions of the Convention. Iran would have to adhere to this Convention which is against the necessities of Islam, the indisputable criteria (dawābit) of Islam and against several principles of the constitution, especially article 2 and $3^{34}$, $4,10,20,21,72,115,153$. Especially the first articles of the Constitution focus on Islamic belief and rules as the basis of the Islamic Republic of Iran. ${ }^{35}$

Focusing, as said before, on the micro-level of the terminology, I will seek to answer the following questions:

1. Which terminology for gender-roles - gender-(in)equality is used? What other key concepts are discernable?

2. What do these terms and concepts reveal about the basic gender concepts?

3. Can the discussion of those concepts of gender-relations proposed by the protagonists be judged as a "translation" of international law into local contexts or must it be seen as a "revision" of the letter and spirit of the Women's Convention?

In a first step I will take a look at two terms which are of pivotal importance for the gender-discourse: tasāovi which means in Arabic and Persian according to the dictionaries " "equality" and tashāboh, which, also from an Arab root, means if looked up in the dictionary "similarity". In what follows it will become evident that the translation as looked up in the dictionary is not in accordance with the "cultural translation" as e.g. by "Alāsvand. The "transnational or international dialect" so heavily criticized by Abu-Lughod, is, as will become evident for the Iranian context, not imposed with the accompanying concepts but introduced into the national and cultural context of the Iranian legal discourse.

It is not possible to discuss gender roles and questions of gender equality in the Islamic Republic without reference to Āyatollāh Moțahhārī (1920-1979) an influential cleric and ideologist of the Islamic Republic because he is often referred to in the discussions about gender. Also the two jurists whose discussion I will analyze, 'Alāsvand (2004) and Mawlāverdī (2003-2005), quote him. Further important terms are "feminism" because here especially "Alāsvand defines her position in rejection of those "Western" concepts defended by "feminism", as she argues and to which Mawlaverdi also refers, as well as "Islam" or "Islamic law". Finally it is interesting

accessed on July 12, 2014.

33 See: http://www.un.org/womenwatch/daw/cedaw/text/eConvention.htm, accessed on July 12, 2014: 2. A reservation incompatible with the object and purpose of the present Convention shall not be permitted.

34 See: http://www.iranonline.com/iran/iran-info/government/constitution-1.html, accessed on July 12, 2014.

35 I have a copy of the Council's writing to the Parliament.

36 Emāmī 1386/2008.

37 Ibid. 
to look on a formal level at the arguments in favor or against an implementation of the CEDAW in Iran.

\subsection{The protagonists}

\subsubsection{Mortażā Moțahharī (1920-1979)}

Āyatollāh Mortażā Moțahharī (1920-1979) ${ }^{38}$ was one of the main proponents of Shiite modern thinking on family issues. His major book The System of Women's Rights in Islam (Pers. nezām-e hoquq-e zan dar Eslām) was a polemic against the defenders of male-female equality as reflected in the UNDHR on two grounds. He argued against the Western tendency to measure the status of women in different societies in terms of its observance. He saw the Declaration as being based on the philosophy of "individualism" which was in his view contrary to Islam - an argument which was taken up, as we saw above, by Abu-Lughod in her critique of the "dialect" of the AHDR. The Middle Eastern - in Motahharī's words: the Islamic world clearly gives priority to the rights of society over the rights of the individual and that is why Muslims are obliged to observe social rules as stated in the Quran. He argues that the call for "equality" of rights irrespective of sex is unacceptable in Islam because it confuses "equality" with "similarity" or sameness of rights. ${ }^{39}$ This reference to "equality" and "similarity" became a slogan in the gender-discourse of the Islamic Republic and will be analyzed more detailed below.

\subsubsection{Farība 'Alāsvand}

Farība 'Alāsvand (1967-) is called a Shiite religious authority in Iran by the Wikipedia-article ${ }^{40}$ dedicated to her, she holds an $\mathrm{PhD}$ in women's issues and is professor at Zahra University (hawże) in Qom. She published a book in 2004 entitled "Critique of the CEDAW" (Pers. Naqd-e konvensyūn-e raf'-e kolliyyeh-ye eshkāl-e tab 'iże alayhe zanān) in which she examines the CEDAW in detail, rejecting it as "un-Islamic". She argues from the view point of international law, national Iranian law and Islamic law. During my field research in Iran between October and December 2008 I interviewed her. In January 2014 she was appointed a member of the High Council of Cultural Revolution (Pers. Shürā-ye 'alī-ye enqelābī-ye farhangīi), ${ }^{41}$ and therefore holds an important political position in the country.

\subsubsection{Shahīndokht Mawlāverdī}

Shahīndokht Mawlāverdī is a jurist and for a long time was head of International Affairs at the Center for Women's Participation. In 2003 as head of this center she

38 See also: http://en.wikipedia.org/wiki/Morteza_Motahhari, accessed on February 5, 2014

39 Paidar 1997: 175.

40 See: http://en.wikipedia.org/wiki/Fariba_Alasvand, accessed on February 5, 2014.

41 http://feydus.ir/ShowNews-218293.aspx, accessed on February 5, 2014; see also: $\mathrm{http} / / /$ radio.irib.ir/persian/modulespage.aspx?modulename=radiomaaref_AExpert\&id=180\&Por talID=12 accessed on February 5, 2014. 
was active and pushed for the ratification of the CEDAW albeit with reservations. ${ }^{42}$ In 2008 she criticized many points of the draft law on Personal Status then proposed by the government. ${ }^{43}$ She has written much and about the CEDAW in particular "Equality between women and men: complete similarity or difference with equality" (Persian title: Barābarī-ye zan o mard: tashāboh-e moṭlaq yā mutafāvet amma musāvī, without date) ${ }^{44}$; "Islam and Equality of woman and man - according to which reading?" (Persian title: Eslām va-barābarī-ye zan va-mard, bā kodām qirā'at?, March 2002); Discourse of welfare and CEDW (Persian title: Goftomān-e mașlahatgerā va-konvensiyūn-e raf'-e kolliyyat-e eshkāl-e tab'ị̣̣ 'alayhe zanān, 6. 1383/August 2004). She was recently appointed as Rouhani's vice president and head of the Center of Women and Family Affairs. As will become evident this could mean a serious change in the gender policy of the Islamic Republic of Iran - but it is still too early to be sure about this. ${ }^{45}$

Both jurists refer in their arguments to the same key terms and concepts.

\subsection{Tasāvī and tashāboh: the terminology on gender equality}

What terminology is used to negotiate gender (in)equality and to which concept of gender relation is it connected? How is the reference to the CEDAW established? The translation given by the dictionary for $\operatorname{tas} \bar{a} v \bar{\imath}=$ equality and tash $\bar{a} b o h=$ similarity is also the translation Motahharī uses in the English abridged version of his book "The Qur'ānic view of human position of women", but as will be shown his understanding and definition of equality is quite different from the definition given in the international Conventions. Mortażā Moțahharī advocates "equality" (Arab./Pers. $\operatorname{tas} \bar{a} v \vec{\imath})$ while explicitly speaking out against "similarity", or "resemblance" (Arab./Pers. tashāboh).

Saying that: tasāvī/barābarī are the equal legal rights of men and women (hoqūqü-ye mosāvī-e yekdīgar) and that no legal privileges are given ${ }^{46}$, it is selfevident that "equality" (tas $\bar{a} v \bar{\imath})$ is part of human nature (haythiyyat-e insāni $)$ and that equality is to be counted a human right (hoqūq-e ensānī).

He states that Islam "is not opposed to the equality of the rights of men and women; it is opposed to the similarity of their rights" ${ }^{34}$. He views tashāboh to mean that the rights of men and women are "motashäbīh" and "monotone" (yeknavākht) writing

42 Osanloo 2009.

43 Schneider 2010.

44 Publications without date are quoted with the short title. I use this and the following article because in it she elaborates on the terminology of this discussion especially with reference to equality, which is, as we will see, a sensitive issue.

45 For further information see: http://fa.wikipedia.org/wiki/\%D8\%B4\%D9\%87\%DB\%8C\%D9\% 86\%D8\%AF\%D8\%AE\%D8\%AA_\%D9\%85\%D9\%88\%D9\%84\%D8\%A7\%D9\%88\%D8\%B1 $\% \mathrm{D} 8 \% \mathrm{AF} \% \mathrm{DB} \% 8 \mathrm{C}$ accessed on February 5, 2014.

46 Moțahharī 1978: 111ff.

47 Moțahharī: Quranic View: 6.

48 Moțahharī 1978: 111. 
If we decide not to blindly imitate Western philosophies, i.e. giving ourselves the right to ponder on philosophical thoughts and opinions which are imparted to us, we should first see whether the equality of the right demands the similarity of them or not. Equality is not similarity - equality is the state of being equal; that is the same in number, size, merit, etc., while similarity is merely likeness or resemblance. ${ }^{49}$

For him the term "tashāboh" is obviously negative, $\operatorname{tas} \bar{a} v \bar{\imath} /$ equality is positive:

... It is possible, therefore, that a father distributes his wealth among his children equally (be-tour-e motas $\bar{a} v \bar{\imath}$ ) but not with similarity. For instance, suppose that his wealth consists of such items as commercial firms, arable lands, rental estates and so forth, and that he has previously measured his children's talents and faculties, discovering one's taste in trade, other's interest in agriculture and the other's skill imagining the affairs concerning the real estates. He would, therefore, allocate to each of his children an equi-value portion, regardless of any privilege or preference, which is simultaneously in harmony with their talents and interests; in other words, an equal but dissimilar share. ${ }^{50}$

Seen before the backdrop of Islamic inheritance law this example is strange because according to Islamic law there are clear portions for every person according to his/her status in the family which include a gender difference in what males and females are entitled to; a female at the same relationship level - here in this case daughters - gets half of the male's share, the son. In Persian the word "farzand" can be equally applied to a son or a daughter as is the case with the English word "child"; so the example does not give any clue about his understanding of gender "equality".

He continues that Islam does not establish similar or identical rights for both men and women but also says that Islam never favors men with any legal privilege and preference which it withholds from women. Islam strictly observes the principle of the equality of human beings. ${ }^{51}$ Why has Islam established dissimilar rights for men and women in a number of instances? In what follows he deals (1) with the Islamic view of the human position of women in creation and the aims of the differences in creation between men and women. Do these differences cause a dissimilar situation for men and women so far as their natural rights are concerned $?^{52}$

The matter on Islam's account is that man and woman, due to the very reason that one is a man (male) and the other a woman (female), are not unanimous in many respects. The world is not the same to both of them. They have been destined by nature and creation not to receive absolute sameness. These de-

49 Motahharī: Quranic View: 4-5.

50 Ibid.: 5; Moțahharī 1978: 112.

51 Moțahharī: Quranc View: 5-6.

52 Ibid.: 9-10. 
mand a dissimilar situation for them in a great range of rights, obligations and penalties. $^{53}$

Nowadays, he argues, efforts are being made in the West to bring about a unanimous state in laws and regulations for men and women regardless of the natural and instinctive differences by which they are distinguished. This draws the line of difference between Islam's view of women and that of Western systems of thought. In his country it is the problem of similarity, not the equality of rights which creates the controversy between partisans of Western laws and advocates of Islamic laws.

However, imitators of the West have labeled "the similarity of rights" (which is the real point of argument) with the counterfeit mark of "the equality of rights" (on which Islam has no argument). ${ }^{54}$

And "Islam does not maintain the same type of rights, duties and penalties for men and women in all circumstances. Rather, it considers certain rights, obligations and punishments more suitable for men than for women and vice versa" ${ }^{955}$. In the end it becomes evident that because of this "natural" difference polyandry is against human nature whereas polygyny is accepted by Islam. ${ }^{56}$

\section{'Alāsvand}

According to 'Alāsvand the keyword of the Convention is "absolute equality between woman and man" (tasāvi-va-barābarī-ye moțlaq-e zan va-mard). Referring to Mortażā Moțahhārī and the writings in "our country" this kind of equality must be seen as "tashāboh" and therefore rejected:

The result is, that the Convention is in contradiction not only from the religious standpoint in the area of $f e q h$ and obligation, but also from our beliefs and our theoretical basics; to say it with other words: the Convention in all and principally and fundamentally is in contradiction with our religious point of view and does not fit in the frame of sharia. ${ }^{57}$

Being a "keyword" one would expect 'Alāsvand to extensively explain why "similarity" is the content of the Convention but she does not elaborate on this. In footnote 1 on page 36 , she only gives some clues, when for example saying that an examination of the Convention shows that the Convention negates sex (jensiyyat). ${ }^{58}$

53 Moțahharī, Quranic View: 19.

54 Ibid: 20.

55 Ibid.: 1.

56 Motahharī 1978: 336-337.

57 'Alāsvand 2004: 35.

58 For the English version of the CEDAW see: http://www.un.org/womenwatch/daw/ cedaw/text/econvention.htm accessed on July 12 2014; there is only an Arabic official translation on the UN-Website, but 'Alāsvand has given a Persian translation in the annex of her book, see 149-66. 
She refers to the Introduction and the Articles 10 and $11^{59}$ which run in English as follows:

\section{Introduction}

[...]

[...] all human beings are born free and equal (Italics mine, IS) in dignity and rights and that everyone is entitled to all the rights and freedoms set forth therein, without distinction of any kind, including distinction based on sex, (Italics mine, IS).

$[\ldots]$

\section{Article 10}

States Parties shall take all appropriate measures to eliminate discrimination against women in order to ensure to them equal rights with men in the field of education and in particular to ensure, on a basis of equality of men and women (Italics mine, IS):

[...]

(a) The same conditions for career and vocational guidance, for access to studies and for the achievement of diplomas in educational establishments of all categories in rural as well as in urban areas; this equality shall be ensured in pre-school, general, technical, professional and higher technical education, as well as in all types of vocational training;

(b) Access to the same curricula, the same examinations, teaching staff with qualifications of the same standard and school premises and equipment of the same quality;

Article 11

States Parties shall take all appropriate measures to eliminate discrimination against women in the field of employment in order to ensure, on a basis of equality of men and women (Italics mine, IS), the same rights, in particular: $[\ldots]$

The phrase "including distinction based on sex" is for her tashäboh. ${ }^{60}$ Quoting the articles regulating the gender relations in the Convention she merely summarizes them without commenting them or corroborating her claims. ${ }^{61}$ She states that according to Article 1, the special position of women in the family may not be the basis for these differentiations. ${ }^{62}$

59 'Alāsvand's quotations abridge the text and do not correspond accurately with her translation given in the annex of her book.

60 But in the translation of the Convention's text which she gives in the annex ('Alāsvand 2004, 149-166) the English "equality" is given either as the Persian barābarī or the Persian-Arabic tasāvi. The Arabic version of the CEDAW uses in these places the Arabic musāwät (Introduction, Art. 10) and tasāw $\bar{\imath}$ (Art. 11), all derived from the same Arabic root (s-w-y).

61 'Alāsvand 2004: 27-32, dealing with article 1-16.

62 'Alāsvand 2004: 28. 
For the purposes of the present Convention, the term "discrimination against women" shall mean any distinction, exclusion or restriction made on the basis of sex which has the effect or purpose of impairing or nullifying the recognition, enjoyment or exercise by women, irrespective of their marital status, on a basis of equality of men and women, of human rights and fundamental freedoms in the political, economic, social, cultural, civil or any other field.

She does not comment upon Article 4, in which the adoption of special measures aimed at protecting maternity shall not be considered discriminatory, which shows that the Conventions does differentiate between males and females and gives special prerogatives to women as mothers. For her it is completely obvious that absolute equality ${ }^{63}$ is not compatible with Islamic religion, so that "we" have to choose either the Convention or the religion. The Convention will abolish the differences between the sexes, in the name of the struggle against discrimination. Even if there would be only Article 1 in the Convention, the discrepancy with Islam would be enough. Islam clearly distinguishes between the sexes with regard to rules and ethics. ${ }^{64}$ These very general arguments do not give any clue which phrases would give exact reference to "absolute" equality. There is no explicit argument so that one cannot help but has to state that she reads the term tashäboh - as she calls it "absolute equality" - into the text.

Dealing with gender concepts on the basis of religious and legal arguments she states that soul (rūhāni $)$ is not gendered in Islam (färegh as jensiyyat) and there are common propositions between men and women in ethics $(a k h l a \bar{q})$ and jurisprudence $(f e q h)$, but there are physical and some psychological differences between the sexes

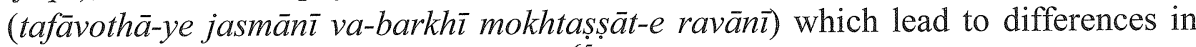
the gender morality $(a k h l \bar{a} q)$ and rights. ${ }^{65}$ She deals extensively with the differences of gender from the biological and psychological point of view, quoting "scientific" confirmation, referring to 'Allāmeh Țabātabā'î̀ (1892-1981) ${ }^{66}$ according to whom differences in jurisprudence between men and women rest on two factors. The first is that women "being the field" or "being the place of cultivation"(Pers. herth büdan) according to a Qur'ānic verse (2:223):

Your wives are a place of sowing of seed for you, so come to your place of cultivation (harth) however you wish and put forth [righteousness] for yourselves. And fear Allah and know that you will meet Him. And give good tidings to the believers. ${ }^{67}$

And second is again a biological-psychological argument, an alleged "softness of the physical constitution" (letâfat-e bonye) and a "thinness of perception" (reqqat-e

63 Ibid.: 53 .

64 Ibid.: 54.

65 'Alāsvand 2008: 38.

66 http://de.wikipedia.org/wiki/Allameh_Tabatabai, accessed on July 12, 2014.

$67 \mathrm{http}: / /$ quran.com/2, accessed on July 12, 2004. 
$e d r a \bar{k}){ }^{68}$ The first, the "being the field" she explains, anyhow, being based on Quran, points according to her also to woman's role in reproduction. This, as she explains, brings women in the special position of "being desired" (matlübiyyat). With regard to gender relation they are effected and sometimes vulnerable because of their very close relation with life, in birthing and raising their offspring they have a qualitatively and quantitatively different relation to men (mardān). The "softness of the physical constitution and thinness of perception" also point to the delicacy (zeräfat) of the thoughts of women. Because of their volatile sentiments (ehsāsāt-e jūshān) women are more attracted to beauty-seeking elements ('unșur-e $z \bar{\imath} b \bar{a} ' \bar{i} k h \bar{a} h \bar{\imath}$ ), creativity (honar-âferin) and everything which stems from sentiments. ${ }^{69}$

The "softness of the physical constitution" is the reason why women are seen as fragile and therefore exempted from certain obligations; they are not suited to deal with some social hardships. Not because they are denied rights, she says, but there are special obligations which are only taken from their shoulders as e.g. judgment, jihād and testimony/martyrdom (shahādat). As these are mere obligations and no rights religion does not deny women any rights ${ }^{70}$.

She substantiates her claim that physical differences, e.g. rooted in the female and male hormones, create psychological differences. Hormones and especially estrogen influence the feeling and behavior of women. The male hormone testosterone makes men able for heavier work, at the same time more aggressive and quarrelsome. ${ }^{71}$ As there are physical as well as psychological differences between men and women which even (some of the) feminists do not deny we do have to take them into consideration in different dimensions of the live of the individual and the family and society. From the position of religion these differences cannot be regarded as defects (naqs). She regrets that the international Conventions do not pay attention to this and quotes Quran 30:30:

[...] No change should there be in the creation of Allah. That is the correct religion $[\ldots]$

To summarize: whereas Islam accepts equality (tas $\bar{a} v \bar{l})$, but what is in the Convention is not (Islamic) equality, she concludes that the concept of gender relation in the Convention is to be identified with the term tashäboh/similarity. She explains this by arguing that the Convention does not take into consideration the differences between the sexes. However, she presents no evidence for this claim. Even the Persian translation in the annex of her book uses the terms barābarì/tas āvī. Just like Motahhārī she twists the terminology. What is in normal use of a) dictionaries b) the language in the Convention and c) even the Persian translation of the Convention in

68 'Alāsvand 2004, 38.

69 Ibid.

70 Ibid.

71 Ibid.: 40 . 
her own book translated with tasāvi becomes tashäboh. The second "twist" is the one between "rights" and "obligations". Defining judgment, i.e. the office of a judge, as well as others as "obligations" and obligations being too hard for women, so that they have to be taken "from their shoulders" she twists rights to obligations and thereby denies those rights to women.

Mawlāverdī

Mawlāverdī is well aware that the concept of "equality" (Pers. barābarī) is one of the main points of critique of the opponents of the ratification of the Convention ${ }^{72}$ and begins her article by summarizing the arguments of the CEDAW's opponents: They see the "spirit" of the Convention in absolute "similarity" (tashāboh-e mutlaq) of woman and man and against the pattern of proportion/suitability (tanāsob) of woman and man. God gave man and woman different talents, so they should have different rights and duties. ${ }^{73}$ On the other hand, this form of equality (baräbari $)$ has many disadvantages for society, is contrary to the welfare (mașāleh) of women, neglects woman's role as mother and wife, the cohesion of the family, etc. Consequences include the increased marriage age, etc. which are incompatible with Islam. ${ }^{74}$ Mawlāverdī quotes 'Alāsvand ${ }^{75}$ in her praise of the Islamic system and woman's role within it. Islam gives answers in a reasonable way (tarz-e ma 'qūlī) to natural requirements and desires; the husband who has to pay maintenance to his wife is obliged to act as the head of the family (qiyām) whereas the preferred space of female activity is the private sphere and the home. ${ }^{76}$ Against this it has been argued - and in what follows becomes evident that this is her own position, too - that the construction of the family is contingent on history. She criticizes Motahhari for adopting the position of traditional scholars who, based on the family structure at the beginning of Islam considered the laws regarding the family as eternal and unchangeable, whereas the development of Muslim society in recent times must be taken into consideration. Historical inequality of women should be ended and women should be given equal rights without endangering the family structure. ${ }^{77}$

The aim of the Convention, she now points out, is not to bring about indisputable equality (barābarī) or absolute and mathematical equality (tasāvi-ye moțlaq variyażì $)$, but - as seen in Article 1 - to abolish discrimination. She refers to line one of Article 1, the definition of "discrimination" (tab ì $\bar{l}$ ) against women as "any distinction, exclusion, restriction on the basis of sex (jensiyyat) which has the effect or purpose of impairing or nullifying the recognition, enjoyment or exercise of human rights and fundamental freedom in certain areas". With this quotation of Article 1 of

72 Mawlāverdī 1381/2002: 133.

73 Ibid.

74 Ibid.: 134.

75 However, not her book which I used here, because her article was published before 'Alāsvand wrote her book.

76 Ibid.

77 Ibid.: 134-135. 
the Convention Mawlaverdi points to the main areas of discrimination: the rights and freedoms in the political, economic, social, cultural, civil or any other field. ${ }^{78,79}$ She also points to other articles: Article 6,10 and $12^{80}$ which take gender differences into account. Whereas in Article 6 the states declare to take all measures to suppress prostitution and traffic in women, in Article 10 they promise to create equal opportunities in education. Mawlāverdī does not make sufficiently clear what the point of her quotation is with regard to this article, but Article 12 refers to health-care and special options for women during pregnancy, confinement and the post-natal period as well as adequate nutrition during pregnancy and lactation; it surely corroborates her argument that the Convention here differentiates between the sexes and gives special rights to women. ${ }^{81}$

Equality of sexes (barābarī-ye jensiyyati) means for her: equal chances, equal standing, just conditions; physical, mental and intellectual abilities have not to be taken into account, as well as economic or social position. Non-equality has its roots in history, and, caused by patriarchal structures, exists even in developed societies. ${ }^{82}$ As she points out, this Convention was written under the influence of the post-modern feminism of the 1970s, the slogan of which was equality ( $\operatorname{tas} \bar{a} v \bar{\imath})$ of women and men despite biological differences. ${ }^{83}$ The aim was to get equal basic rights for men and women knowing that biological difference exists. The question is, how equality in the area of civil, political cultural, social, and economic rights can be implemented in spite of these natural and biological differences. Or, she asks rhetorically: should this difference between man and woman result in the superiority of one over the other? To this 'Alāsvand would have of course answered in the affirmative. According to Mawlāverdī, however, it is a fact that discrimination against women does not result from natural or biological conditions but from discriminating social orders as well as social injustice which has to be stopped. It becomes evident that it does not contradict the Convention to give women in some fields special concessions (emtiy $\bar{a} z$ ). She repeats over and over that women cannot be denied equal rights to men because they are women. Both are human beings with honor and dignity (haithiyyat va-karāmat) and their human rights. ${ }^{84}$ The "spirit" (rūh) of this and other conventions is to give individuals their natural rights (hoqūq-e țabi $\bar{\imath}$ ). As the spirit of the Convention is to guarantee human rights for all this is in accordance with many Islamic rules and regulations. Some try to place Islam in opposition to the justice-seeking spirit of the Convention, but Islam is a proponent of justice and equality.

78 Mawlāverdī, Barāberī: 3 .

79 http://www.un.org/womenwatch/daw/cedaw/text/eConvention.htm accessed July 12, 2014.

80 Mawlāverdī 1381/2002: 136.

81 Ibid.: 136.

82 Mawlāverdī 1383/2004: 213.

83 Mawlāverdī speaks nowhere of "psychological" differences, she only refers to biological differences between men and women.

84 Māwlāverdī 1381/2002: 135. 
To summarize, it becomes evident that both scholars see "equality" as an important concept of the Convention and the discourse in Iran. Neither of them denies differences between the sexes in biology but they differ in its definition and consequences:

- Mawlāverdī and 'Alāsvand focus on different positions on the Convention, summarizing the opponent's and the supporter's arguments and then explaining their own point of view. 'Alāsvand, however, speaks of "we", with reference to Iran, thus "nationalizing" her argument and "othering" every other possible voice.

- The principal difference between Mawlāverdī and 'Alāsvand with regard to content can be seen in the fact that Mawlāverdī sees human rights as compatible with Islam and cites a "spirit" of the Convention which is in accordance with Islam whereas 'Alāsvand sees a principal incompatibility.

- 'Alāsvand argues that what is meant in the Convention is not equality/tasāō but similarity/tashāboh which is - with Moțahhārī - negative and seen as absolutely incompatible with Islam. It means "absolute" equality and does not take note of the obvious biological and psychological differences between men and women. She thus twists the terminology and what is used normally as "equality" in the Convention's translation becomes "similarity", tashāboh, because she argues (but does not convincingly prove) that "similarity" is the concept enshrined in the Convention. Obviously she takes Moțahhārī"s argument that "Islam is for equality and against similarity" as starting point. As she cannot accept the concept of gender equality in the framework of the Convention she has to rename it "similarity".

- Mawlāverdi on the other hand sticks to the "usual" translation of "equality" in the Convention and criticizes Moțahharī, albeit not explicitly his concept of tashāboh but more generally his unhistorical and static use of a concept of family and gender roles. Whereas Mawlāverdī's concept of "equality"( $\operatorname{tas} \bar{a} v \bar{\imath})$ includes differences between the sexes though only with regard to biology, 'Alāsvand also deals extensively and with much reference to research in the area of biological differences in emotions and characters resulting from physical differences, and mentions differences in the area of psychology.

- Mawlāverdī argues that "equality" (or "similarity") is not the most important topic of the Convention, but the prohibition of discrimination on the basis of sex dealt with in Article 1. Important in the Convention is not so much the question what exactly equality is and whether or not there are (biological) differences between the sexes (which are biologically seen in pregnancy and lactation, emotional differences are not mentioned, and are alluded to e.g. in the articles 6, 10, 12) but that it is not allowed to discriminate against women on the basis of their sex because men and women are equally bearers of human rights.

- She thus argues for inherent equal rights of men and women, whereas 'Alasvand spends much time in explaining and justifying the biological and psychological differences between men and women - to conclude that these differences of the 
sexes have to have the consequence of different rights of women and men. Furthermore, she differentiates between "rights" and "obligations", arguing that because of their physical constitution women are not able to take over certain "obligations" - as jihäd and jurisdiction. With this clever distinction she now can go on to "take" certain "obligations" "from women's shoulders" to make life easier. As these obligations are no rights, women are not denied rights. With this euphemistic wording she conceals effectively the denial of rights to women, which she renames as "responsibility" (Pers. mas 'üliyyat) and/or "obligation" (Pers. taklīf), a religious term normally connected to religious duties.

Biological arguments taken as a basis for denying women rights and positions in society are age-old and gained special "scientific" importance in $19^{\text {th }}$-century Europe. As Schwarz has shown, the discourse in late Victorian and Edwardian England biology laid down that women were ruled by their unruly emotions, were less likely to listen to the voice of reason and therefore a potential danger which had to be contained. She quotes Henry Maudsley:

They cannot choose but to be women; cannot rebel successfully against the tyranny of their organization: this is (...) the plain statement of a physiological fact. ${ }^{85}$

Darwin assumed the male brain to be more highly evolved than the female brain and described woman's constitution including emotional characteristics such as intuition, imitation and irritability as similar to that of the "lower race". The age-old notion of women being more easily dominated by extreme emotions - based on an gendered dichotomy of male/rational and female/emotional - was incorporated in $19^{\text {th }}$ century England into the new scientific discourse, in this way acquiring the appearance of scientific authority in an age that contemporaries celebrated as scientific. ${ }^{86}$ It is exactly this discourse which is taken up by 'Alāsvand with the intention to prove on the basis of "clear" "scientific" results - sided with arguments of Quran - woman's inferiority.

\subsection{Feminism}

A second important concept which is used as an argument is "feminism", which is not translated into Persian - in Arabic there exists e.g. nisā 'iyya as a neologism for this concept.

\section{'Alāsvand}

'Alāsvand deals with the history of the word "feminism" as a new creation in the $19^{\text {th }}$ century in French, stating that fighting for women's education for example has a long history. She repeats very roughly and not always accurately the common classi-

85 Schwarz 1997: 147.

86 Ibid.: 145. 
fication of feminism into three waves and what is meant by this. ${ }^{87,88}$ Starting from the beginning of the $19^{\text {th }}$ century and lasting until the end of the First World War, she describes the first wave as a phase of development of liberal, Marxist and socialist feminism. She names Mary Wollstonecraft (1759-1797) as the representative of liberal feminism, whom she describes as a reformer and not a revolutionary. According to 'Alāsvand Wollstonecraft believed in differences of the sexes but was opposed to inequality in family and society. She also deals with the first feminist movements in the beginning of the $20^{\text {th }}$ century. Women used the situation caused by the first and second world wars and the absence of men to take men's place as workers e.g. in industry and the "gender difference between women and men was forgotten" $"$. In the second wave of feminism beginning in the 1960s two important lines of feminist thought came into being: radical and liberal feminism. ${ }^{90}$ She describes radical feminists as fighting against the patriarchal structure of society to overcome the traditional idea of monogamic (tak hamsary) marriage and thereby rejecting the concept of motherhood. The representatives of this group authorized abortion, all kinds of sexual satisfaction including homosexuality (ham-jens-gera $\bar{\imath}$ ). She presents Simone de Beauvoir (1908-1986) as a representative of this view.

She describes two other trends, one of which is the "revival of motherhood, whose representatives saw feminist ideas as compatible with the family and motherhood. She mentions Germaine Greer (1939-) especially her book "Sex and Destiny" in which she revised some of her main former thoughts and radical ideas. ${ }^{91}$ The second group fought for female superiority above males and was also in opposition to liberal feminism which stood for equal rights between men and women.

Feminism in post-modernity believes that all schools of thought - liberalism, Marxism, feminism - which claim to know reality are faulty. Feminism can thus be criticized because there can be no single definition of female identity; race, class, gender and culture, etc. are components of identity as well.

Feminism - and here 'Alāsvand seems to include all kinds of feminism - tries to give the answer to three questions: (1) How do we define women? (2) What are the reasons for this position? (3) Which solution for the change of this position do we suggest? All feminists are against oppression (forūdastī). She explains that all feminist schools stick to the individualism of women. She harshly criticizes the fact that all forms of feminism give priority to women's freedom and honor ('ezzat vasharaf) as individuals rather than to their social duties, obligations to the family and their country. Some radical feminists even vote for the right of self-determination

87 'Alāsvand 2004: 9-18.

88 See Wikipedia http://en.wikipedia.org/wiki/Feminism accessed July 12, 2014: normally Charles Fourier (d. 1837) is mentioned as the first person to have coined the word "feminism". She does not give the most important names and definitions and is not very accurate especially when dealing with the newest developments of gender theory.

89 'Alāsvand 2004: 10.

90 Ibid.: 11.

91 Ibid.: 11-12. 
(tasalloț-e zanān bar khwishtan). Especially radical feminists and even liberal feminists think that women as independent human beings have the right to live according to their instincts. They even claim the right to abortion. ${ }^{92}$ 'Alāsvand complains that the question of self-determination has lead Western women so far that they consider the birth control pill to be progress whereas it would be more important to get the right to vote. ${ }^{93}$ It therefore becomes evident that the feminist movement's most important principle is independence of the individual (esteqlāl-e fardī). Even those feminists who believe in the family and a woman's role as a mother see women as independent in the family and recognize or accept a certain competition between her rights and those of the family. 'Alāsvand sees this as a contradiction to the Islamic view in which women and men equally have a soul ( $r \bar{u} h)$ in which women are considered at the same time individuals and members of a family and society and women's independence is firmly rooted in family and society. ${ }^{94}$ This position prevents selfishness. Furthermore, in religion the relationship of the individual to God has to be taken into consideration and the religious concept of the soul is not gendered. ${ }^{95}$

'Alāsvand seems to be well aware of the concept of gender as a social construct and explains the difference between biological sex (Pers. jens) and gender as a social construct (pers. jensiyyat). Feminists argue, she explains, that that these differences should not influence the order of the family or society. ${ }^{96}$ Some feminists, she continues, deny even these biological differences, a position which she cannot accept because of opposing "scientific findings" $"$ " As mentioned above she gives a whole list of physical and psychological differences between men and women relying on what she calls the "achievement" (dastäward) of the science of biology. ${ }^{98}$

Her main point of criticism therefore can be seen in the concept of individualism, individual independence and independent personality, and the individuality of women which have priority over all other social and legal aspects. ${ }^{99}$ This brings feminism into open opposition with the institution of the family and other social institutions. She also criticizes the "secularism" and "liberalism" forced on the world from Western culture, not with particular regard to feminism but in general. ${ }^{100}$

In these two points, as already mentioned, 'Alāsvand comes very close to the arguments of Abu-Lughod: the family which is in a normative way is seen as of higher value than individual rights and freedom and the "West's" dominance with regard to these concepts.

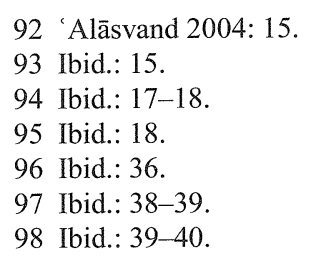

99 'Alāsvand 2004: 15-16.

100 Ibid.: 39. 
With regard to the Convention she sees a feminist influence in Article 5 (2), citing here the Convention's wording "maternity as a social function". She explains that this is influenced by feminists. Whereas motherhood was usually seen as an important task, as a domain of great responsibility which women were expected to bear alone, feminists believe, according to 'Alāsvand, that it was wrongfully described as delightful and joyful. She calls this talk "null/void" (bātell) and in opposition to all scientific research. For her it is evident that the fact of being a woman is of course connected to motherhood. ${ }^{101}$ She overlooks that the Convention's text which of course does not refer to those "feminist talks" - here explicitly refers to motherhood and makes it a physical marker between men and women connected to special rights for women in this situation. This is actually in accordance with her arguments. Also she cannot and does not want to accept obligations towards children as the "common responsibility of men and women" as stated in the Convention as she would see them as "normally" connected to motherhood. ${ }^{102}$

\section{Mawlāverdī}

Mawlāverdī, unlike 'Alāsvand, does not deal with feminism explicitly but refers to it only implicitly, and her definition of the feminist groups is even more blurred than 'Alāsvand's. She argues that the Convention has been written under the influence of post-modern feminism without defining what this had been in the beginning of the 1970s. As stated above, it contains equal rights for men and women despite physical differences. ${ }^{103}$ Nowhere are differences between the sexes denied, even by the "modernist" feminists ${ }^{104}$ or the "authoritarian" (eqtedārgerā) feminists who do not defend complete similarity of men and women. It is principally not possible to ignore freedom and human rights under the pretext of race, age, religion, sex. ${ }^{105}$ She poses the question that today, where we watch the three waves of feminism in Iran (the "proof-seeking", "seeking cquality" and "authoritarian") and are aware of the non-transparency of the feminist sphere, should not the supporters of Islamic women's rights find the appropriate answers to the questions women face today? ${ }^{106}$ The answers to this question will correspond to the position of the first-wave-feminism. And: Should the danger of the third-wave-feminists bring us in to oppose all of it?

Both 'Alāsvand and Mawlāverdī would accept the arguments of the first and second wave of feminism but do not agree with the positions of the third wave, that of postmodern feminism. The adjectives modern, post-modern, radical and liberal are not

101 Ibid.: 29-30.

102 Ibid.: 30.

103 Mawlāverdī, Barābarīi: 3.

104 Mawlāverdī 1381/2002: 138. Mawlāverdī only implicitly refers to the constructional character of gender and does not take modern trends of gender studies into account.

105 Mawlāverdī, Barāberī: 4.

106 Mawlāverdī 1381/2002: 138-139. 
deliberately used. It is obvious that both consider feminism as something strange and new to Iran, as stemming from a Western context, and that post-modern feminism in particular is in contradiction to Islamic values. This points to a powerful discourse that discredits "feminism" as something strange, something that does not belonging to Islamic history.

Margot Badran approaches the of problem of what feminism is with a broader definition. She writes:

... feminism is broadly construed to include an understanding that women have suffered forms of subordination or oppression because of their sex, and an advocacy of ways to overcome them to achieve better lives for women, and for men, within the family and society. ${ }^{107}$

She uses this broad definition to be all-inclusive without the intention of suggesting a monolithic feminism. She argues that Muslim women have generated two major feminist paradigms, which they have referred to as "secular feminism" and "Islamic feminism". But these have never been hermetic entities. Nor, concomitantly, have those known as "secular feminists" and "Islamic feminists" operated strictly within the separate frameworks that their designations might suggest. ${ }^{108}$

In her book "Women, Islamism and the State" in Egypt, Azza Karam refers to an equally broad definition but constructs three ideal-types of feminists: secular, Muslim and Islamist feminists. Without going into detail here, it can be said that secular feminism in the sense of focusing on the individual human rights of men and women without any relation to religious concepts is not very common in the Muslim world. In Iran, as stated above, there is no discourse on a secular interpretation of human rights, the discourse on human rights is always based on Islamic arguments. Whereas roughly speaking Muslim feminists support the idea of gender equality as rooted in Islamic sources, Islamist feminists (who by the way would never call themselves feminists) argue that differences in biology and psyche result in different rights and duties within society. ${ }^{109}$ According to this concept, Mawlāverdī would be counted as a Muslim feminist but it is doubtful that she would ever call herself such. 'Alāsvand would be an Islamist thinker, but as she does not even try to opt for more female rights or agency she could never be called a feminist. Anyway, the ideas 'Alāsvand proposes - non-equality because of biological and psychological differences between the sexes etc. - are neither new nor special to Iran.

In her article "Feminism in an Islamic Republic", Najmabadi analyzes the discourses on "feminism" and, of the 1990s, states that feminism was seen in connection with "individualism" and rejected as "un-Islamic". ${ }^{110}$ However, she also highlights the important role played by the journal Zanān ${ }^{111}$, which first appeared in

107 Badran 2011: 18.

108 Ibid.: 2-3.

109 Schneider 2014: 173-179.

110 Najmabadi 1998.

111 Ibid.: 63-65, 72-73. 
1992 and was closed down in 2008. At least in this journal the accepted connections between differences-in-creation and women's rights and social responsibility as developed by "Alāsvand were overturned. ${ }^{112}$ Najmabadi goes so far to state that Zanān broke down the dichotomy between secular and Islamic women in Iran. However, if this is true for the widely-read and acclaimed journal Zanān it is not true for the legal discourse in the Islamic Republic as a whole, as is clear in the arguments of 'Alāsvand. Furthermore, the question of how women could argue on the basis of "secularism" is not easily answered. At least at the end of the first decade of the $21^{\text {st }}$ century it was not longer possible to argue on the basis of secularism or, more concretely, on the basis of international human rights. ${ }^{113}$

Mehrangīz Kār, an Iranian woman who would perhaps call herself a feminist, divides female activists into two groups: conformists and non-conformists. As the gender-concept of the Iranian state can surely be roughly called Islamistic ${ }^{114}$ one could call 'Alāsvand and Mawlāverdī protagonists of these two positions, 'Alāsvand being conformist, and Mawlaverdi non-conformist. But how can we interpret the fact that both women were given high political positions under Rohani? This shows on the one hand how problematic many of these categorizations are and second that antagonistic positions are not only present but are simultaneously perhaps also promoted possibly by different actors or players in the Islamic Republic.

\subsection{Islam}

'Alāsvand

'Alāsvand ${ }^{115}$ deals extensively with the incompatibility of Islam, or more exactly, feqh-e Eslämī and dīn-e Eslämī, and the Convention. She argues that there are common obligations and restrictions which apply to the whole of Islam which led the Muslim states to either not sign the Convention or sign it with reservations. She looks at these points while focusing on comparative feqh, taking also the Sunnī schools of law into consideration alongside Shiite feqh. According to her two points need to be dealt with in advance, first: absolute equality or similarity (see 3.2 ) and second: the fact that the Quran is an important but not the only source of Islamic religion and jurisprudence. ${ }^{116}$ She discusses several areas of family and penal law, including the age of marriage and divorce regulations, etc. - all of which are areas where classical law contradicts international law and gender equality as defined in the Convention. ${ }^{117}$ Here I will concentrate only on one point: the question of polygyny.

112 Ibid.: 67.

113 See: Schneider 2010: 404-405, in the discussion about the new Family Draft Law in 2008 publicly no voice was raised for international human rights, e.g. for the CEDAW.

114 Paidar 1997: 303-355.

115 Alāsvand 2004: 53-88.

116 'Alāsvand 2004: 53-55.

117 Schneider 2014: 88-91. 
The differences between men and women as mentioned above are confirmed in the Quran. She invokes the Quranic verse 4:3 on polygamy, according to which taking "justice" ( $a d \bar{a} l a t$ ) into account - a man can be married to up to four women at the same time. She quotes Quran 4:3 in Arabic and Persian translation. She argues that this does not apply to women while at the same time every relation besides legal marriage is forbidden for women and is equally a crime called zinā. Polygyny is for her the solution to problems which arise e.g. from war when there is a lack of men. She praises Quranic regulation in its "justice" to protect the first wife against harm (zarar). However, this justice refers to external regulations such as giving the same amount of maintenance to all wives, not for example to feelings like love.

In the end she states that these different rights of men and women with regard to polygamy is unanimously accepted by "Islam" because it is rooted in the Quran and in several traditions. It is incompatible with the articles 1 and 16 of the Convention. The right to practice polygamy as in the Quran is also anchored in Iranian national legislation to which she is also committed. ${ }^{118}$

\section{Mawlāverdī}

As we have seen, Mawlāverdī is convinced that Islam and human rights can be brought together. Her principal argument is that nobody should be deprived of her/his rights because of her/his sex. Already the title of her article "goftemān mașlahatgerā va-CEDAW" - meaning "discourse of acting in the interest of public welfare and the CEDAW" shows Mawlāverdī's different approach. She is not focusing on feqh of the four Sunnī schools of law or the Shiites. Her goal is not to point to common "Islamic" dogmas which, according to Alāsvand, are based on Quranic rulings such as polygyny and lead her to the opinion that the CEDAW cannot be accepted. Instead, Mawlāverdī focuses on modern developments of feqh. She deals with the creation of the Expediency Council in 1988 as the result of a deadlock between the Parliament - the legislative body - and the Council of Guardians. This body examines the laws passed by the Parliament for compatibility with the constitution and with sharia. She describes the Expediency Council more or less as a strategic organ to resolve deadlock and concludes that both institutions have more or less the same competence as the Expediency Council does not have a monopoly in interpreting feqh and is unable to legislate against sharia. ${ }^{119}$ In this context she quotes Moțahhāri - the gender-theoretician mentioned above - with an interesting comment: When rationalism and public welfare are criteria for legislation in an Islamic society, this is Islamic. ${ }^{120}$ But if inflexibility prevails over rationalism there is no place for Islam in society. Protecting public welfare might sometimes go so far as to lead to the abrogation of a prohibition (hukm-e harami $\bar{\imath})$, rendering it allowed (halāl) or obligatory (wājib). The understanding of religion is bound to time and

118 'Alāsvand 2008: 66.

119 Mawlāverdī 1383/2004: 205-207, see 207.

120 Ibid.: 206-7. 
space and the role of women in particular has to be seen in this context. She explains that this is not in opposition to religion. One way is to look for Quranic verses, hadith, and traditions that have not been looked at, another is to take mașlahat into consideration. With maslahat the requirements of time and place can be taken into consideration. Can we not, she asks, be religious and give women and men the same rights? ${ }^{121}$ Why should there be differences at the expense of women only to the benefit of men?

Mawlāverdī quotes many important scholars in Islamic history to show that interpretation of the law changes and has to change according to time and space. According to Imam Khomeini ijtihād is dynamic. She quotes Ayatollāh Jannatī who argues that ijtihäd is an instrument that harmonizes feqh with life. ${ }^{122}$ She turns to Egypt and Qāsim Amīn (1863-1908), the scholar who is often seen as the first feminist. Amīn advocated that women have to be seen as protected persons who have the same rights and duties as men. For him the root of the problem lies not in religion but in tradition. He was, she argues, convinced that it would be possible to give women their deserved place in society. ${ }^{123}$ Furthermore, she points to Muhammad 'Abdūh, also Egyptian, whose aim was not, as she explains, to imitate the West to find ways out of what he saw as the decay of the Islamic world. She mentions Muhammad Jawād Mughniyyah (1872-1979) ${ }^{124}$, a Shiite scholar from Lebanon who was convinced that the religious rituals ('ebādāt) are not explicable, but that rules and laws can be comprehended and that the jurist has to discover indicators. ${ }^{125}$ Mawlāverdī states that in the area of ritual one has to rely on the texts, but in the area of human relations ( $m$ ' $^{\prime} \bar{m}$ malāt) reasonable mașlahat must be taken into account. Finally she refers to Khātamī, Iranian President from 1997-2005 who coined the idea that feqh had to be avant-gard (pǐstāz). Again (see also 3.5), she points to the idea of human rights and gender equality as a universal idea that states must take into consideration. While it is necessary to adhere to cultural and religious identity, integration into the global community is also imperative so as not to miss the train. These values are undeniable. Mawlāverdi considers the differentiation between men and women to be a consequence of worldwide patriarchal society and concludes: It is a fact that true Islam (Eslām-e vāqe $\hat{\imath}$ ) is in complete agreement with the standards of international human rights. ${ }^{126}$ And:

If there seems to be sometimes a conflict (ta 'âroż), one should cast doubt on the reading of Islam or the understanding of human rights. ${ }^{127}$

121 Ibid.: 211.

122 Ibid.: 212.

123 Ibid.

124 http://islamtimes.org/vdcayenu.49nyilgtk4.html, accessed July 12, 2014.

125 Ibid.: 213.

126 Mawlāverdī 1383/2004: 214.

127 Ibid. 
Dogmatism is not scientific, she argues. There are different interpretations of feqh as well as of human rights but the principle is human dignity according to which texts must be interpreted. She repeats that nobody can be deprived of his/her rights on the basis of gender ${ }^{128}$.

To summarize, both scholars refer to Islam and are eager to show that Islam is the source for their respective positions on the CEDAW. 'Alāsvand sticks more to the classical feqh and wants to give the impression that other interpretations are not acceptable; she refers to no new approaches in Quranic interpretation. On the other hand, Mawlāverdī is well aware of these different approaches, and to an even greater extent to the fact that Islamic texts as well as human rights texts such as the Convention are open to human interpretation. Logically, she refers to the spirit of Islam - which is for her compatible with human rights - and to several historical and contemporary scholars in Iran and other Muslim states who opted for a "dynamic" interpretation. She does not go into detail concerning conflicting views between a classical or traditional interpretation of gender roles and modern approaches towards this topic. Nor does she refer to legislation in other Muslim states. Instead she takes recourse to Iranians. In her article she often refers to "the Imam", meaning Khomeini, but also to President Khātamī, the hope of the reformers and President of Iran at the time of writing.

\subsection{Strategic arguments in favor of or against the ratification of the CEDAW}

'Alāsavand

Some supporters of the ratification of the Convention, whom 'Alāsvand mentions very briefly, vote for its ratification with reservations, something she is against because these reservations can be cancelled. Whether or not the reservation is void ( fäsid) is, as she explains in a footnote ${ }^{129}$, a legal question. ${ }^{130}$ Furthermore, international pressure under which reservations are often withdrawn has to be taken into consideration. ${ }^{131}$ In chapter seven she presents several arguments against the ratification and rejecting the arguments supporting the Convention: (1) the pressure exerted by the international community; (2) the alleged impossibility of acting in the realm

128 Ibid.: 215.

129 'Alāsvand 2004: 26, footnote 2.

130 The issue is admissibility, in particular the legal consequences of entering an inadmissible reservation in the ratification of a human rights covenant. A sharia-based reservation is an example of an inadmissible reservation because it undermines the fundamental concept of the CEDAW, i.e. the elimination of discrimination against women. The reservation contravenes the covenant's very purpose (Art. 19ff. Vienna Convention on the Law of Treaties). Art. 28 of the CEDAW itself prohibits such reservations. There is a debate in the field of human rights on this issue that has been developing the stance that these types of inadmissible reservations have no legal impact to the effect that they do not limit the said state's obligation to comply with the covenant. see: http://www1.umn.edu/humanrts/gencomm/hrcom $24 . h t m$. I would like to thank Christine Langenfeld for this comment.

131 'Alāsvand, 2004: 26. 
of the international community without ratifying the Convention; (3) the necessity of change to national legislation; (4) the question of whether the Convention will, or has already become an international legal custom (jus cogens). ${ }^{132}$ With regard to these points she argues as follows:

1. Iran is already criticized for gender discriminatory laws, a fact that will not change upon ratification because this would be accompanied by reservations (Pers. shurüt). If Iran ratifies it is then obliged to provide regular reports and there is a push towards international standards that are in opposition to Islam.

2. To act in the world without ratifying the CEDAW is not impossible. If Iran had a seat in the CEDAW committee it would, according to supporters, be able to influence the discussion about Islam and to correct misunderstandings about Iranian and Islamic law in the UN. Rejecting this, 'Alāsvand states that in similar situations such as when Iran was chair of the OIC, Iran has been unable to use this position as an instrument. It is true that the world needs the voice of Islam but this can be done elsewhere.

3. With regard to national legislation, she describes the position of supporters who argue that Iranian laws could develop on an Islamic basis for women under international influence. 'Alāsvand concedes that some laws might be discriminatory but that the constitution of Iran has principles which safeguard women's interests. She calls for legal development in Iran itself without foreign pressure.

4. The Convention and gender equality are not yet internationally binding customs, a jus cogens, as the jurists call it. 'Alāsvand ${ }^{133}$ asks whether the Convention is already a legal custom binding for all countries, noting that many countries have signed it (albeit with reservations) whereas some did not ratify it at all. The Convention is not part of the international custom. ${ }^{134}$ She connects this to the Islamic Republic's legal system and that of other Muslim states as well as to the declaration of Islamic human rights.

Her final statement is that Iran together with the OIC-states should develop an Islamic Charter for Women's Rights, concluding that the arguments in support of the CEDAW are weak and thus uncompelling. Finally she not only draws the conclusion the CEDAW should for no reason be ratified, but that its ratification would even be harmful to women. ${ }^{135}$

\section{Mawlāverdī}

Mawlāverdī's starting point is "mașlahat" which can roughly be translated as "public welfare". She explains that governments or rulers in Islam have the possibility to use this theoretical tool in case of a conflict between sharia and a rule (hokm) ${ }^{136}$ She

132 Ibid.: 133-145.

133 Ibid.: 126.

134 Ibid.: 128-129.

135 'Alāsvand 2004: 132-140.

136 Mawlāverdī 1383/2004: 203. 
quotes Khomeini himself, who argued that the protection of the order of the state is the highest "maslahat" because it is a national mașlahat. Even the most important Islamic rituals such as pilgrimage may be suspended if necessitated by national welfare because pilgrimage will not take place if the welfare of the Islamic Republic is in danger. ${ }^{137}$ Mawlāverdi defines mașlahat as a benefit that the lawgiver provides for his citizens by protecting religion, life, reason, offspring and property.

States supporting cultural relativism should be reminded that human rights are a worldwide accomplishment. Equality for gender - not equality of the sexes - giving them the same rights and fair chances without taking physical differences into consideration in all areas is included. Inequality is rooted in history, cultural thought and patriarchal structures especially in traditional societies but also in developed societies. ${ }^{138}$ Women's rights play an important role and the most important indicator is the ratification of the CEDAW. Iran is part of the global community. Other Muslim states have already ratified it. Moreover 1/6 of the convention drafting committee came from states with a Muslim population. Again referring to Khomeini who saw mașlahat as a priority to protect the Islamic state, she broadly points to the fact that especially in Shiite Islam interpretations that favor gender equality are possible. ${ }^{139}$

She points to other Islamic countries which have signed the CEDAW. Mawlāverdī sees Iran in danger of being isolated on an international level because the state has yet to ratify the CEDAW. ${ }^{140}$

Starting with Risse/Sikkink's "spiral-model" according to which international human rights Conventions are or are not introduced into national contexts and after having stated that Iran - not having ratified the CEDAW - is stuck on phase 2 of this model i.e. "denial", I argue that the process of accepting or not accepting international human rights is more complex and necessitates a closer look. The national actors, 'Alāsvand and Mawlāverdī, are well aware of the international pressure and the arguments in favour and against its ratification. So although the CEDAW is not ratified, the content of this international convention is hotly and controversially debated in an Iranian context.

\section{Conclusion}

On the basis of what has been said, taking advantage of the so-called translational turn has been vital to understanding how categories "travel" and "arrive" and are then integrated into a national discourse. It is essential to look at these translations not only in a pragmatic way by checking which terms are chosen as equivalents in

137 Ibid.: 203-204.

138 Ibid.: 213.

139 Ibid.: 215-216.

140 Ibid.: 215. 
the other language in e.g. the official translation of a document or convention, but in a wider sense, as an analytical tool to understand the underlying political and social discourses which may lead to new legislation. The discussion about the ratification or non-ratification of the CEDAW focused on certain terms and concepts, of which gender-equality and/or "similarity", the role of feminism in the drafting of the Convention and the question of compatibility with "Islam" or Islamic jurisprudence were examined as the most prominent. Hopefully it has been shown how eminently important it is to carefully examine the terminology and connected concepts. This analysis reveals that there are in fact interesting shifts and twists in meaning when discussed in Iran - as is surely also the case elsewhere. The normal understanding in the Convention's text, the Arabic (and also the non-official Persian translation), and the dictionary, etc. of "equality" as gender equality now becomes for "Alāsvand "similarity". On the other hand, the Arabo-persian tas $\bar{a} v \bar{\imath}$ is used for an "Islamic" concept of "equality" which includes gender-unequal regulations as permission for polygyny. This discourse is influenced by Moṭahharī, who coined the statement "Islam is for equality but against similarity". Similarity is understood and defined as the complete ignoring of differences between men and women and loaded with the negative connotations of "complete identicalness" and "making everything the same" which cannot, as is stated over and over again, be accepted in Islam. This is a common argument of both scholars.

It has not only become obvious that the discourse in Iran was deeply influenced by Moțahharī's critical attitude towards what he calls "similarity" and "absolute" equality, but that this is somehow a hegemonic discourse. 'Alāsvand used and referred to it, reading it into the Convention's text, but also Mawlāverdī in her more defensive style felt obliged to prove that "similarity" is NOT the Convention's spirit and that absolute equality is not what matters.

According to the international discourse, the question whether or not there are biological differences or even psychological differences between the sexes plays no role, nowhere is this mentioned in the Convention. The argument is rather whether or not there are differences as sex cannot be used as reason for discrimination. So 'Alāsvand's lengthy explanations and arguments that there is scientific proof for the difference between men and women are not the point. To the point in is her conclusion, namely that these differences lead to different rights for men and women. After having interpreted the Convention's term "equality" as "similarity", she adds a twist in definition of "rights" as "obligations" which are "taken from women's shoulders". This implies an improvement for women where actually it is meant to hinder them from e.g. becoming judges. Like Mawlāverdī she draws on many arguments: biologistic, psychologistic (not Mawlāverdī) and religious, here referring especially to the Quran $^{141}$, but excludes any social arguments ${ }^{142}$.

141 If presumed that English translations are being used in the international human rights dialogues, this can lead to confusion! If one uses the "normal" translation of tas $\bar{a} v \bar{\imath}$ as "equality" on which to base a reading of Moțahhārī's statement that Islam has nothing 
The resulting question was whether the "translations" proposed by the two protagonists need to be seen as a revision of the letter and spirit of the Women's Convention. This was presumed by Bachmann-Medick for the Islamic context, in particular with regard to the Islamic Human Rights Declaration (Cairo Declaration). With regard to 'Alāsvand's position, it is obvious that she revises the understanding of "equality", setting the Convention's terminus for equality against an Islamic term for equality that is at least used in the Arabic version of the Convention, stuffing it with a conservative "Islamic" content based on gender inequality. Thus for example the acceptance of polygyny while explicitly denying women the same right (to marry several men) is clearly incompatible with the Convention's prohibition to discriminate against women. She is well aware of this and therefore argues frankly against its ratification. On the contrary, Mawlāverdī proposes that gender equality/tasā $\bar{\imath} \bar{\imath}$ is possible in "(the) Islam", her understanding would match the English "equality"concept of the Convention. However she is cautious not to touch upon sensitive topics in detail and thus never mentions the question of polygyny but only generally points to a possible new interpretation of Quranic verses. She probably avoids this topic knowing that polygyny is firmly rooted in the Iranian legal system as in many other legal systems of Muslim states - with the exception only of Turkey and Tunisia - knowing that the abolishment of polygyny is a "taboo-topic" in legal discourse which cannot be touched upon. Just as many other Muslim states, in the case of ratification Iran would have to make certain reservations. On the other hand Mawlāverdī speaks out for the possibility of further developing Islamic law to adopt it to the changing conditions of life and adds that the spirit of Islam, or what she calls "true" Islam, is compatible with human rights.

Following Bachmann-Medick's proposed terminology, it can be argued that Mawlāverdī "translates" into the Iranian cultural context, whereas 'Alāsvand revises. Both 'Alāsvand and Mawlāverdī's systems of reference are equally religious - even if one comes to the conclusion of a potential acceptance of equality in Islamic law, and the other denies it. This also shows that the "arrival" of international legal norms is interwoven with cultural patterns and bound to the local discursive context. Mawlāverdī's approach indicates that processes of inter-cultural norm-building as claimed by Bachmann-Medick ${ }^{143}$ are possible, but the two contradictory opinions of 'Alāsvand and Mawlāverdī also demonstrate the difficulty of these processes and how uncertain it is that they will ultimately influence legislation. For the time being this seems rather unlikely in Iran, even before the backdrop of the new appointments of both scholars to high political positions.

against gender equality, one is lead to believe that the absolute legal equality as enshrined in the Convention is also given in this Islamic interpretation whereas it is, in fact, not. Again it becomes obvious how important it is to look at the accurate understanding and the interwoven cultural concepts.

142 see Schneider 2010.

143 Bachmann-Medick 2012: 339. 
The final question was under which condition states "rest" on a certain position in the spiral model and how this is connected to the so called "principled ideas" mentioned by Risse/Sikkink. The discourse goes much further than debating the ratification of an international Convention. It is the reflection of an inner-Iranian discourse of different gender-models on the basis of "scientific" biological arguments as well as the question of the "right" interpretation of Islam as either compatible or incompatible with human rights and gender equality. Risse/Sikkink ask about the conditions under which the spiral model can be interrupted, resulting in the stabilization of the status quo of norm violation. We can observe this in the case of Iran: it consists of repression (= stage 1) and consistent denial (= stage 2) combined with more repression against those circles discussing the CEDAW and at the same time the development of "other competing principled ideas". These "other competing principled ideas" - i.e. the Islamic concept of gender-difference - are promoted to confront concepts of international human rights. Supporting those concepts and ideas becomes not only a state sponsored concept but also the hegemonic discourse, defaming other concepts as "Western" and thus displacing or even eliminating them. These "other principled ideas" are very powerful in Iran. 'Alāsvand offers a whole counter-model to what she - but also Abu-Lughod - consider to be the "imperialistic" "Western" concept of gender-roles and gender-equality. Whereas both 'Alāsvand and Abu-Lughod, a conservative professor of the Islamic Republic and feminist scholar in the US, support the idea of "family" against individualism, 'Alāsvand goes one step further by justifying different family roles by referring to biology and religious arguments. Both, 'Alāsvand and Abu-Lughod, take the terminology, concepts and discourses of international human rights into consideration and explicitly refute them, but again 'Alāsvand goes one step further in building up "our" concepts, a point which Abu-Lughod is missing.

Non-observance of the UN Conventions may lead to a process of "shaming" as argued by Risse/Sikkink, but if the hegemonic counter-model of gender relations is strong enough and has the state's backing, the tables are turned: 'Alāsvand sees no need whatsoever for Iran to be "ashamed", but rather self-assured. She promotes the idea that it is necessary for Iran to work towards an independent declaration of Islamic human rights, a counter-model to the whole human rights catalogue. Shaming only functions on the basis of (implicit or explicit) acceptance of rules that have been violated. In the event that those rules are not accepted at all, if there are "other powerful principled ideas", shaming is instead transformed into a self-confident representation of these principled ideas, whatever they may be.

'Alāsvand teaches at the state-funded Madrasa of Zahra in Qom. One could therefore develop the hypothesis that she is part of a state- sponsored project to develop and promote an "Islamic answer" to international human rights and Western gender-role-models. From this point of view it is interesting to point to her rhetoric. Often she speaks of "us" and "them". This is the creation of a hegemonic discourse through the promotion of special scholars and groups, giving them political posi- 
tions. However, even when the hegemonic discourse is powered by the state, it is not possible to silence other "translations" completely.

\section{Bibliography and Websites}

Abu-Lughod, Lila (2009): Dialects of women's empowerment: the international circuitry of the Arab Human Development Report 2003, in: International Journal of Middle East Studies 41, 83-103.

'Alāsvand, Farībā (1382/2004): Naqd-e konvānsyūn-e raf'-e kolliyyeh-ye eshkāl-e tab 'ìże 'alayhe zanān. Qom: Enteshārāt-e markaz-e modiriyat-e ḥowze-ye 'elmiyye.

Ali, Shaheen Sardar (2000): Gender and human rights in Islam and international law: equal before Allah, unequal before man? The Hague: Kluwer Law International.

Bachmann-Medick, Doris (2012): Menschenrechte als Übersetzungsproblem, in: Geschichte und Gesellschaft 38, 331-359.

Badran, Margot (2009): Feminism in Islam - secular and religious. Oxford: Oneworld Publications.

Baer, Susanne (2011): Travelling concepts: substantive equality on the road, in: Tulsa Law Review, 101-121.

Buskens, Leon (2003): Recent debates on Family Law reform in Morocco: Islamic law as politics in an emerging public sphere, in: Islamic Law and Society 10, 70-131.

Emāmī, Karīm (1386/2008): Farhang-e mo āṣer-e Kīmiyā. Tehran: Farhang mo 'āṣer.

Hafner-Burton, Emilie; Kiyoteru Tsutsui \& John W. Meyer (2008): International human rights law and the politics of legitimation. repressive states and human rights treaties, in: International Sociology 23, 115-141

Karam, Azza (1998): Women, Islamism and the state: contemporary feminism in Egypt. London, New York: Palgrave Macmillan.

Mawlāverdī Shahīndokht (1381/2002): Eslām va-barābarī-ye zan va-mard, bā kodām qirāàat, in: Raihānel.

Mawlāverdī, Shahīndokht (1383/2004): Goftomān-e maşlaḥate-gerāw va-konvensiyūn-e raf́e kolliyyat-e eshkāl-e tab 'ị̣ 'alaihe zanān, in: Raihāne 6 .

Mawlāverdī, Shahīndokht (without date): Barābarī-ye zan va-mard: tashāboh-e moṭlaq yā motafāvet amma mosāvī. copy.

Merry, Sally Engle (2006): Human rights \& gender violence: translating international law into local justice. Chicago: University of Chicago Press.

Muțahharī, Murtażā (no date): The Qur'anic view of human position of women. The International Scientific Educational Relations Department, Isfahan University, trans. by Hossein. No place.

Muțahharī, Murtażā (1357/1978): Nezāam-e hoqūq-e zan dar Eslām. Tehran, Qom: Enteshārāte Șadrā.

Najmabadi, Afsaneh (1998): Feminism in an Islamic Republic: "Years of hardship, years of growth", in: Yvonne Yazbeck Haddad \& John L. Esposito (eds.), Islam, gender, and social change: New York: Oxford University Press, 59-84.

Najmabadi, Afsaneh (2006): Bexond the Americas: Are gender and sexuality useful categories of historical analysis?, in: Journal of Women's History 18, 11-21.

Osanloo, Arzoo (2009): The politics of women's rights in Iran. Princeton: University Press Group. 
Osanloo, Arzoo (2012): What a Focus on "Family" means in the Islamic Republic of Iran, in: Maaike Voorhoeve (ed.), Family law in Islam: divorce, marriage and women in the Muslim world. London, 51-76.

Paidar, Parvin (1997): Women and the political process in twentieth-century Iran. Cambridge: Cambridge University Press.

Risse, Thomas \& Kathryn Sikkink (1999): The socialization of international human rights norms into domestic practices, introduction, in: Thomas Risse, Stephen C. Ropp, Kathryn Sikkink (eds), The power of human rights: international norms and domestic change. New York: Cambridge University Press, 1-38.

Schneider, Irene (2010): Civil society and legislation: development of the human rights situation in Iran 2008, in: H. Elliesie (ed.), Beiträge zum Islamischen Recht VII, Islam und Menschenrechte. Frankfurt a. M., 387-414.

Schneider, Irene (2014): Women in the Islamic world. From earliest time to the Arab Spring. Princeton: Markus Wiener Publishers.

Schwarz, Angela (1997): "They cannot choose but to be women." Stereotypes of femininity and ideal of womanliness in late victorian and edwardian Britain, in: Ulrike Walton-Jordan \& Wolfram Kaiser (eds.), Political reform in Britain, 1886-1996: themes ideas, policies. Bochum: N. Brockmeyer, 131-150.

Welchman, Lynn (2003): In the interim: civil society, the Shar'i Judiciary and Palestinian Personal Status Law in the transitional period, in: Islamic Law and Society 34, 34-69.

'Alāsvand:

http://en.wikipedia.org/wiki/Fariba_Alasvand, accessed on July 12, 2014.

http://feydus.ir/ShowNews-218293.aspx, accessed on Feburary 20, 2014.

http://radio.irib.ir/persian/modulespage.aspx?modulename=radiomaaref_AExpert\&id=180\&P ortalID $=12$, accessed on February 5, 2014

CEDAW:

http://www.un.org/womenwatch/daw/cedaw/, accessed on February 4, 2014.

Human Rights committee: general comments, see:

http://www1.umn.edu/humanrts/gencomm/ hrcom24.htm, accessed on July 1, 2014.

Feminism:

http://en.wikipedia.org/wiki/Feminism, accessed on June 30, 2014.

Mawlaverdī:

http://fa.wikipedia.org/wiki/\%D8\%B4\%D9\%87\%DB\%8C\%D9\%86\%D8\%AF\%D8\%AE\%D8 \%AA_\%D9\%85\%D9\%88\%D9\%84\%D8\%A7\%D9\%88\%D8\%B1\%D8\%AF\%DB\%8C accessed on February 5, 2014.

Motahharī:

http://en.wikipedia.org/wiki/Morteza_Motahhari, accessed on February 5, 2014.

Muhammad Jawād Mughniyyah:

http://islamtimes.org/vdcayenu.49nyilgtk4.html, accessed on February 12, 2014. 



\title{
Personal Status Law in Lebanon
}

\author{
Imen Gallala-Arndt
}

\section{Introduction}

In the political and social sciences, the state has so far mostly been evaluated as to whether it is strong or weak. ${ }^{1}$ Strong states are able to deliberately transform the society according to their ideologies. According to this image, the society is subject to the exigencies of the centralized, harmonized and autonomous state power. Conversely, a weak state is portrayed as having little, if any, influence on its society, whose internal groups enjoy a large autonomy and successfully resist any attempt of the state to manipulate them or to shape them according to its visions. According to this definition, Lebanon would be a weak state, since it leaves a very decisive field of defining of norms to the discretion of the recognized ethno-religious communities. In fact, according to the Lebanese Constitution the state respects religious personal status. As a consequence, Lebanon lacks a unified family and succession law applicable to all Lebanese citizens irrespective of their religious affiliation. Every recognized religious authority has its own family law and its own tribunals. Nevertheless, civil or state tribunals exist and have competence in some personal status matters. The attitude of the Iebanese state towards family law is quite uncommon, as the wide majority of other states featuring post-colonial governments are keen to hold family and succession regulations under their control since this allows them to bring about certain goals in the social and the economic spheres. ${ }^{2}$

However a close look at the structure and the history of the system of personal status in Lebanon reveals the complexity of the issue. It is more accurate to analyze the system from a dynamic perspective. ${ }^{3}$ This shows that also the state in Lebanon is constantly negotiating with the religious authorities over the division of competence between religious norms and state norms. In Lebanon the state is trying to overcome the shortcomings of its religion-based legal pluralism. In this context the judiciary plays a pivotal role, as the personal status system is very difficult for the state to

1 Migdal, Joel S. (2001): State in society - studying how states and societies transform and constitute one another. Cambridge: Cambridge University Press, 58-59.

2 Sezgin, Yüksel (2013): Human rights and state-enforced religious family laws in Israel, Egypt and India. Cambridge: Cambridge University Press, 27.

3 Ibid.: 25-26. 
manage. Subjecting the Lebanese citizens to different family and successions laws according to their religious affiliations very often leads to the violation of human rights, especially the right to equality before the law. The state is permanently confronted by a dilemma: On the one hand having to manage the exigencies of the religious groups and their authorities and, especially, to respect their autonomy; and on the other hand vindicating the right of the members of these groups as citizens to have their constitutionally enshrined rights enforced by the state. One has at this level to emphasize a particularity of Lebanon. Specifically, the Lebanese state itself has no official religion which is quite unique in the region of the Middle East. ${ }^{4}$

In this article, I will first make some brief remarks about the history of Lebanon and the foundation of the state (I), which are necessary to understand the specificities of the personal status system there. Then I will analyze the current system of personal status (II). I will afterwards highlight the impact of such a system on human rights as well as on the harmony of the Lebanese legal order in general (III).

\section{Lebanon}

Lebanese law reflects the structure of the Lebanese nation as a mosaic of religions and ethnicities. ${ }^{5}$ When the Muslim Arabs began founding the Islamic empire in the seventh century the Middle East was mostly Christian. ${ }^{6}$ Diverse Christian denominations existed then on the territory of what is today Lebanon. The rugged mountains in Lebanon made it an attractive refuge for religious dissidents and persecuted heretics. ${ }^{7}$ Under Islamic rule, the members of the non-Muslim communities in the newly conquered territories had a particular status. They were called "Ahl al-dhimma". The Muslim ruler engaged himself to protect them, if they paid a capitation. Moreover, the non-Muslim religious communities enjoyed according to the dhimma regime a kind of autonomy in the organization of their internal legal issues. ${ }^{8}$ They had a normative and judicial autonomy. ${ }^{9}$ We have to emphasize here that the privilege of normative and judicial autonomy, especially in civil matters, was already accorded to the Christians and Jews under the Roman and the Byzantine empires. ${ }^{10}$

4 Karam-Boustany, Lara (2014): Les minorités religieuses au Liban, 773, http://biblio.juridicas.unam.mx/libros/4/1725/46.pdf (last visited: 11.4.2014).

5 Gannagé, Pierre (2009): Lebanese Law in Face of the Diversity of Communities and Cultures, in: Marie-Claire Foblets \& Jean-François Gaudreault-Desbien (eds.), Cultural diversity and Law: state responses from around the world. Brussels: Emile Bruylant, 333.

6 Steinbach, Udo (2008): Christen im Nahmen Osten, in: Aus Politik und Zeitgeschichte 26/2008, 3.

7 Abdel Mottaleb El Husseini (2008): Die Religionsgemeinschaften im Libanon, in: Aus Politik und Zeitgeschichte 26/2008, 33.

8 Udo Steinbach, Christen im Nahen Osten, 4.

9 Fattal, Antoine (1995): Le statut légal des non-musulmans en pays d'Islam. Beirut: Dar-ElMachreq, 344.

10 Abu-Sahlieh, Sami (1979): L'impact de la religion sur l'ordre juridique: cas de l'Egypte: Non- 
The history of the country has always been determined by this multitude of religions and nations cohabiting on its territory. Many wars and confrontations between the different religious groups steered the destiny of the country. Under Ottoman dominance the millet system (inspired by the early Islamic dhimmī system) gave the diverse religious communities certain autonomy in the organization of their religious rituals, administrative and taxation matters and in legal issues. The conditions of this autonomy differed across the religious communities. While even before the $18^{\text {th }}$ century the Ottoman Jews already enjoyed legal jurisdiction over their members in penal matters, the Christians had it only in personal status matters. Moreover, the characteristics of the status of the non-Muslim subjects were not rigid nor decided exclusively at the central level. The practical implementation of these privileges of autonomy could be renegotiated, especially at a local level. ${ }^{11}$

Under the Mutasarrifat regime decided on the basis of an agreement between the Sublime Porte and the European powers in the mid- $19^{\text {th }}$ century, the religious communities were accorded administrative autonomy and were a kind of an intermediate between the Ottoman authorities in Istanbul and their members. ${ }^{12}$ The communities were at that time already micro-states within the state. The communities were manifold: Druses, Muslims, Christians and Jews with their different and diverse denominations (Maronites, Greek-Catholics, Syrian-Orthodoxes, Shias and Sunnis).

After the dissolution of the Ottoman Empire and the French mandate, the communitarian system was consolidated even further. In fact, the Constitution (still in force) of 1926 guarantees the balanced representation of the different communities in public office, but it did not specify the conditions of such representation. ${ }^{13}$ Unlike other societies with religious diversity, Lebanon treats its religious communities equally. There are in Lebanon different minorities without any group making claim to be majoritarian. ${ }^{14}$ The Constitution does not give to any community a privileged status. The relationship among the diverse religious communities has very often been tense. This is also due to the fact that these religious groups correspond, respectively, to tribal groups and entities. ${ }^{15}$ In the second half of the $20^{\text {th }}$ century the tension between the religious communities led to 15 years of very bloody civil war $(1975-1990){ }^{16}$

musulmans en pays d'Islam. Fribourg: Éditions universitaires, 68.

11 Van den Boogert, Maurits (2012): Millets: past and present, in: Anh Nga Longva \& Anne Sofie Roald (eds.), Religious Minorities in the Middle East. Boston: Brill, 33.

12 Van den Steen de Jehay, Frédéric Marie Joseph Ghislain (1906): De la situation légale des sujets ottomans non-musulmans, Bruxelles: O. Schepens \& cie, 423 esq.

13 Kamal Salibi (1965): The modern history of Lebanon. Delmar/New York: Caravan Books, 167.

14 Karam-Boustany, Lara: Les minorités religieuses au Liban, http://biblio.juridicas.unam.mx/libros/4/1725/46.pdf (last visited: 11.4.2014).

15 Salibi, Kamal (1988): Tribal origins of the religious sects in the Arab East, in: Halim Barakat (ed.), Toward a viable Lebanon. Washington: Center for Contemporary Arab Studies, Georgetown University, 15-16.

16 Perthes, Volker (1994): Libanon nach dem Bürgerkrieg - Von Ta if zum gesellschaftlichen Konsens? Baden-Baden: Nomos, 12-18. 
After the 15-year civil war, the antagonists signed the Taef Agreement, amending in part the Constitution of 1926. The Agreement rebalanced the distribution of power according to demographics: Muslims and Christians equally share the seats in the parliament. Before that the Christians held $66 \%$ and the Muslims only $33 \% .{ }^{17}$ Interestingly, the Taef Agreement solidified the target of progressively eliminating the political communitarianism in order to consolidate the unity of the Lebanese nation, but the agreement did not provide any timetable for the realization of that aim and it is still far from reflected by the political practice in Lebanon. ${ }^{18}$

\section{The religion-based personal status system}

The religion-based personal status system (hereafter: RBPS) created a religious legal pluralism in the ambit of marriage, divorce and succession. This pluralism is anchored in the Constitution of 1926. Art. 9 stipulates that: "There shall be absolute freedom of conscience. The state in rendering homage to the Most High shall respect all religions and creeds and shall guarantee, under its protection, the free exercise of all religious rites provided that public order is not disturbed. It shall also guarantee that the personal status and religious interests of the population, to whatever religious sect they belong, shall be respected". (emphasis added)

The RBPS subjected every citizen in personal status matters to the religious laws and tribunals of his religious community.

The French mandate authority (1923-1943) sought to put an end to the legal pluralism through the establishment of, for example, civil marriage. Facing the harsh opposition of the religious authorities to that reform course, the French authorities were obliged to withdraw the legislation. ${ }^{19}$ In fact, the new legislation unifying personal status regulations applicable to all Lebanese met with the square refusal from both the Christian and Muslim sides. As a consequence, the mandate authorities adopted legal instruments regulating and confirming legal pluralism in personal status matters as inherited from the Ottoman millet system. Some of these instruments are today still in force.

\section{Matters submitted to religious laws}

The regulation of the personal status system in Lebanon has not been the fruit of a comprehensive and well-thought conception. It is rather like a mosaic whose parts were added progressively and based on political circumstances and mostly as a reaction to the demands of the religious communities. In fact, the distribution of com-

17 Volker Perthes, Libanon nach dem Brügerkrieg, 20; Rosiny, Stephan (2011): Religionsgemeinschaften als Verfassungssubjekte: Libanon als Modell für Nahost?, in: GIGA Focus $N^{\circ} 4 / 2011$, 2.

18 Stephan Rosiny, Religionsgemeinschaften, 2.

19 Kahlmeyer, André (2008): Familienrecht und Konfessionalismus im Libanon - Geschichte, Personenstandsregelungen und Zivilehe. Saarbrücken: VDM, 66-67. 
petences among the state and the religious communities in the field of personal status is constantly subject to negotiations in Lebanon.

Regulation 60/LR (13.3.1936) enumerated the recognized religious communities (they are not less than 19) and obligated them to present their religious personal status regulations to the government for ratification (Art.4). ${ }^{20}$ The same text conferred to the religious communities the legislative and judicial competence in the personal status matters of their members (Art.1 Reg. 60/LR).

Only the regulations on the registration of birth, death, marriage, divorce and the change of religion (Law 1951) are applicable to all Lebanese regardless of their religion. ${ }^{21}$ This registration requirement indicates the will of the Lebanese state to have a certain control over private affairs of the citizens regardless of their religion. Apart from these matters, religion is the decisive criterion for the determination of the law applicable in matters of personal status. Nevertheless, not all personal status laws reflect the same degree of pluralism or demonstrate a comparable level of state intervention in the form of codification. Muslims' (Sunni and Shia) personal status is regulated by the Ottoman Family Code of $1917^{22}$ and the Law on the Organisation of the Sharia Tribunals of 16 July $1962 .{ }^{23}$ The personal status of the Druzes is also codified, by the Law of 24 February $1948 .^{24}$ With the exception of succession law, the personal status regulations of the other religious communities (Christian denominations and the Jewish communities) have been adopted by their religious authorities and have not been ratified by the Lebanese government. Nevertheless, the Lebanese Court of Cassation held these laws as applicable for they are the collection of the customs and norms followed by these communities for many centuries. ${ }^{25}$ Moreover, the $\mathrm{CC}$ considered that these religious laws did not violate the public policy or the fundamental rules of the state or of the recognized sects. The inheritance matters of the non-Muslims are regulated by a state law and are submitted to the civil courts. ${ }^{26}$ In addition, natural filiation and administration of the property of minors are regulated by civil law as far as non-Muslims are concerned. ${ }^{27}$

20 Official Gazette Nr. 3273 29.4.1936, 6.

21 Law on Registration of Personal Status Matters 7. 12.1951, in: Nādir 'Abd al- 'Azīz Shāfī (ed.) (2003), Qawānīn al-ahwwāl al-shakhṣiya al-āmma. Țarābulus: al-Mu'assasa al-Hadīta lī alKitāb, 64.

22 Ottoman Family Code 25.10.1917, in: Qawānīn al-aḥwāl al-shakhṣiya al-āmma, 3; Morgan Clarke (2014): Shari'a Courts and Muslim Family Law in Lebanon, in: Elisa Giunchi (ed.), Adjudicating Family law in Muslim Courts. London: Routledge, 34-35.

23 Qawānīn al-aḥwāl al-shakhșiya al- āmma, 284.

24 Qawānīn al-aḥwāl al-shakhșiya al- āmma, 210.

25 Bashīr al-Bīlānī (1997): Qawānīn al-aḥwāl al-shakhṣiya fí lubnān. Bayrūt: Dār al-'ilm lī alMalāyīn, 22.

26 Succession Law for Non-Mohammedian, 23.6.1959, in: Nādir 'Abd al- 'Azīz Shāfī (ed.) (2003), Qawānīn al-aḥwāl al-shakhșiya wa ușūl al-muhākamāt ladā al-țawà if al-masīhīya wa al-țā îfa al- 'isrā '̀llìya fì lubnān. Tarābulus: al-Mu' assasa al-Hadītha li al-Kitāb, 15.

27 Pierre Gannagé, Lebanese Law, 341. 
Because of historical reasons linked to the Ottoman Empire, Islamic law is more integrated into the state structures than the other religious laws. Muslim-related personal status laws are enacted by the state in the form of parliamentary statutes. As a result, the religious Islamic norm is "appropriated" by the state. Theoretically at least, the state is entitled to introduce some amendments to it. This was the case in many Islamic countries where the codification of Islamic family and succession law gave the state the opportunity to change or accommodate some of these Islamicbased institutions. This was, for instance, the case for polygamy as some Islamic states added supplementary conditions in order to limit this practice. By contrast, non-Muslim family laws in Lebanon are exclusively religious and not enactments of the Lebanese parliament. The state has thus no direct access to them and cannot amend them. ${ }^{28}$ We can here find the roots of the difficulty of evolution of family law in Lebanon in comparison with other Islamic countries where the codification of Islamic law allowed the state to amend some of its norms considered as anachronic. $^{29}$

Moreover, the lines defining the frontiers between civil/state laws and religious laws are not identical. They differ according to the religious community or the law in question. This undoubtedly undermines the equality between the religious communities and their laws. One might see in this differentiation the attempt by the state to respect the particularity of each religious law. ${ }^{30}$ Nevertheless, this regulation of the scope of application of religious laws seems at odds with the efforts of the Lebanese state to make its legal policy as cohesive as possible.

\section{Religious tribunalls}

Each recognized religious community in Lebanon normally has its own religious tribunals. ${ }^{31}$ The Alouite community recognized in 1996 is, however, under the jurisdiction of the Shiite/Jaafarite tribunals. ${ }^{32}$ The connection of these tribunals with the state institutions is not uniform. Only Islamic tribunals are state institutions and their judges are state clerks. ${ }^{33}$ This is due to historical reasons as the ruler of Lebanon was for many centuries the Ottoman caliph. ${ }^{34}$ The other religious tribunals are structurally independent of the Lebanese state. They do not render their decisions in the name of the state but in their own name. Their jurisdiction is not based on a delegation of the state of some of its prerogatives but on the latter's recognition of the

28 Gannagé, Pierre (2001): Le pluralisme des statuts personnels dans les Etats multicommunautaires - Droit libanais et droits proche-orientaux. Bruxelles: Presses de l'Université Saint-Joseph, 45.

29 Gannagé, Pierre (2013): Au fil du temps - Etudes juridiques libanaises et proche-orientales, Beyrouth: Presses de 1'Université Saint-Joseph, 303.

30 Pierre Gannagé, Lebanese Law, 341.

31 Bashīr al-Bīlānī, Qawānīn al-aḥwāl al-shakhșiya fĩ lubnān, 26.

32 Law Nr. 553 24.7.1996, in: Qawānīn al-aḥwāl al-shakhșiya al- āmma, 49.

33 Pierre Gannagé, Le pluralisme des statuts personnels, 43-44.

34 Pierre Gannagé, Au fil du temps, 207. 
existence and competences of these religious communities. ${ }^{35}$ In addition, the decisions of these religious tribunals may be appealed against before foreign religious tribunals of the same faith established abroad such as the Rota in Rome. ${ }^{36}$ At this stage the sovereignty of Lebanon seems undermined. Moreover, some critiques have been formulated against allowing the leaders of the recognized religious communities to challenge the constitutionality of a law before the Constitutional Council. Of particular concern is that the religious leaders can be established abroad and not hold Lebanese nationality. ${ }^{37}$

Two important laws regulate to a large extent the jurisdiction of the religious tribunals: the Law on the Delimitation of the Jurisdiction of the Christian Sects and Hebrew Sect of April 2, $1951^{38}$ and the Law on the Organisation of the Shar ${ }^{\mathrm{c}}$ ia tribunals (Sunni and Jaafarite) of July 16, 1962. ${ }^{39}$ The religious tribunals exercise their competence under the supervision of the Lebanese CC. According to Art. 95 Para. 4 of the Code of Civil Procedure, the plenary assembly of the $\mathrm{CC}$ is competent to exercise judicial review against final and enforceable decisions of the religious tribunals. This review is limited to the jurisdiction of the religious tribunals and to whether the judgment they rendered violates a substantial formal aspect of public policy.

It seems therefore that the lawmaker desired to limit the scope of the supervision that the CC might exercise over the decisions of religious tribunals. Nevertheless, the CC itself proved to be inclined to limit the scope of the jurisdiction of the religious tribunals, arguing that the latter has to be interpreted restrictively as it has an exceptional nature. ${ }^{40}$ It has, however, to be added that the jurisdiction of the religious tribunals constitutes an element of Lebanese public policy which implies that the private parties cannot avoid it by an agreement to submit their dispute to another religious tribunal or to a civil tribunal.

\section{Interreligious conflicts of law and jurisdiction}

The religious tribunals apply their respective religious laws in their scope of competence. ${ }^{41}$ In fact, the judicial jurisdiction determines the legislative jurisdiction in Lebanon. That is why the conflict-of-jurisdiction norms are simultaneously choiceof-law rules in the Lebanese system.

35 Pierre Gannagé, Au fil du temps, 207.

36 The Apostolic Tribunal of the Roman Rota is the highest appellate tribunal of the Roman Catholic Church with respect to the vast majority of its Latin rite members and several of the Eastern Catholic Churches.

37 Haidar, Wafa (2011): La dimension religieuse dans le mariage au Liban. Doctoral thesis Université Montpellier I/ Université Libanaise, 30. (unpublished)

38 Qawān̄in al-aḥwāl al-shakhșiya wa uṣūl al-muhākamāt, 4.

39 Qawānīn al-aḥwāl al-shakhșiya al- āmma, 284.

40 Wafa Haidar, La dimension religieuse, 60.

41 Morgan Clarke, Shari'a Courts and Muslim Family Law, 34. 
The religious tribunals are normally competent to adjudicate the cases opposing members of their respective communities, but family relationships are not exclusively inside one religious community. As in Lebanon all the recognized religious communities are considered as equal and no religious law has the status of droit commun (in contrast to Egypt, for example), the state set down abstract conflict norms to determine the competent tribunal. The Lebanese legislator was in that regard conscious that its main role toward the historical heritage of religiously-based legal pluralism is to ensure the coordination between the different religious laws by treating them equally. This can be best illustrated by the example of interfaith marriages. They are to be celebrated before the religious authority of the husband-to-be in cases where the two parties have not agreed to perform the marriage before the religious authority of the wife-to-be. Any disputes resulting out of that marriage are to be submitted to the jurisdiction of the tribunals of the religious authority celebrating the marriage, as provided for by Articles 14 and 15 of the Law on the Regulation of Christian Sects and the Israelite Sect.

Apart from a gender-based discrimination determining that the marriage is to be celebrated before the religious authority of the husband, these norms of conflict seem neutral and do not make any distinction or preferences among the different religious communities and their respective laws. Nevertheless, the state failed in assuring this coordination since the religious courts consider themselves as being subject primarily to their religious laws. It appears that these laws do not always harmonize with the conflict-of-law rules laid down by the state. This is one fundamental shortcoming of the religion-based pluralism in Lebanon.

\section{Shortcomings related to the RBPS}

\section{Threat to legal certainty and the cohesion of the legal system}

The state should through its legal apparatus help people resolve their private disputes in order to achieve social peace. This peace cannot be reached if clarity is lacking regarding the legal solution to a given question. As the legal system of any state is composed of different elements, it is indispensable for the state to assure the cohesion between them. This necessity is even more essential in a system like the Lebanese one where non-state actors, i.e. the religious communities, enjoy considerable legal prerogatives. In addition, being founded on a religious faith, these actors hold their tenets for absolute and inviolable by any other law, even state law. ${ }^{42}$ This undoubtedly makes the efforts of the state to assure cohesion inside the legal system and to coordinate between the different religious orders very difficult. As a result, private parties may find themselves confronted with contradictory decisions about the same matter. This difficulty becomes particularly obvious in the case of interre-

42 Pierre Gannagé, Au fil du temps, 306 
ligious marriages in Lebanon. A marriage can be interreligious at the moment of its conclusion or afterwards if one of the spouses converts to another religion.

As mentioned above, marriage and its effects are submitted to the religious authority having concluded the marriage. Thus, if the marriage is concluded before the Maronite church, the marriage and its effects will remain subjected to the Catholic canonical law even if the husband converts to Islam after marriage. Nevertheless, the Sharia tribunals consider themselves competent if one party to the dispute is Muslim. In case law which has been constant since 1997, the Lebanese CC has repeatedly held that in spite of the conversion, the marriage remains governed by its law of conclusion. ${ }^{43}$ The sharia tribunals however refuse to adhere to this case law, arguing that the conflict-of-law rule mentioned by the $\mathrm{CC}$ is not applicable for the Muslim communities. They even emphasize that they apply the divine law which is superior to any other law. ${ }^{44}$

In addition, the distribution of the competences between civil law and religious law in respect of family issues is in practice complicated. Inevitably conflicts arise between state tribunals and religious tribunals, especially concerning law areas at the intersection of personal status matters and property and obligations issues. The state tribunals tend to respect in that regard the particularity of religious traditions but strive also to keep the legal system on its territory as cohesive as possible. ${ }^{45}$

Legal certainty in Lebanon is threatened also because it has proven to be very difficult for lawyers to find the decisions of the religious tribunals. These are in fact not systematically published. ${ }^{46}$ That is why the Lebanese Union of lawyers applauded the decision of the Egyptian President Nasser eliminating the religious tribunals and unifying the judiciary and accordingly wanted the Lebanese legislator to follow that model. ${ }^{47}$

\section{Violation of fundamental rights}

The religious laws in force in Lebanon are to a large extent at odds with the human rights internationally recognized and also incorporated in the Lebanese law. The Islamic law, for instance, draws a sharp distinction between the faithful and the nonfaithful. Muslim women are thus not allowed to marry non-Muslim men. Moreover the difference of religion is considered as an impediment to succession under the Islamic law prevailing in Lebanon. In the Christian denominations, the impediments to marriage concern both men and women, with however the possibility of receiving dispensations. ${ }^{48}$ The application of a personal status differing along communitarian

43 Pierre Gannagé, Au fil du temps, 308.

44 Mitri, Mounah (2001): Le rôle de la cour supreme libanaise en matière de statut personnel, in: CEDROMA (ed.), Les cours judiaires suprêmes dans le monde arabe. Bruxelles: Bruylant, 126.

45 Pierre Gannagé, Lebanese Law, 340.

46 Bashīr al-bīlānī, Qawānīn al-ahwāl al-shakhșiyya fî Lubnān, 37-38.

47 Țarābulusī, Ibrāhīm (2000): Al-zawāj wa mafā ̄̄luhu. Bayrūt: Maṭba 'a al-Būlusiyya, 28-29.

48 Pierre Gannagé, Au fil du temps, 93. 
lines violates the principle of equality before the law. ${ }^{49}$ For instance, Muslim women in Lebanon can apply for divorce, but Catholic women are denied that right.

Freedom of religion implies that everyone has the right to live his or her religion in the way he or she considers right. Religious laws are the result of an interpretation of religion. ${ }^{50}$ One can be Muslim without adhering to the legal corpus of Islamic law or Catholic without considering oneself bound by canonical law. The very system of religious legal pluralism is based on a confusion of faith and norms as extracted by religious scholars from the holy texts. Such confusion leads to the violation of religious freedom itself. In fact, one might under the Lebanese system be tempted to change his religion in order to secure certain legal advantages. As a consequence, it is not a sincere and authentic faith that guides this individual's attitude but the mere self-interest.

The inconsistencies between the religious-based personal status system and human rights are all the more flagrant given that in 2001 the Lebanese Constitutional Council considered that the preamble of the Constitution is binding. The preamble mentions the Universal Declaration of Human Rights, the International Covenant on Civil and Political Rights and the International Convention on the Elimination of all Forms of Racial Discrimination. ${ }^{51}$

As a consequence, the dilemma the Lebanese state has been facing grows even more embarrassing. The measures that it took to resolve it are, however, concentrated on its role as an arbitrator. By enacting some conflict-of-law and conflict-ofjurisdiction rules, the Lebanese state could soften the negative effects of the religious legal pluralism. For instance, it made certain interreligious marriages possible although the religious authority of one of the spouses oppose them. As mentioned before, Art. 14 provides that the religious authority before which the interfaith marriage was concluded has the jurisdiction to decide on its validity and effects.

The measures taken by the state thus remain external. As expected, it failed in changing the content of religious laws to make them compatible with the constitutionally recognized freedoms and rights. ${ }^{52}$

\section{The struggle for the establishment of a facultative civil personal status}

Establishing a facultative civil personal status law seems the best solution for Lebanon in order to conciliate a respect for the personal status of the recognized religious communities and the fundamental rights and freedom of the Lebanese. This solution would be ideal because it gives the concerned person the freedom to choose between a religious personal status system and a civil one where religion is not relevant. Only under such a model can the freedom of conscience in Lebanon have any sense. It is

49 Art. 7 Lebanese Constitution.

50 Pierre Gannagé, Au fil du temps, 90.

51 Najm Marie-Claude, Le droit international privé libanais entre la réception des Droits fondamentaux et les exigences du systeme communautaire, Footnote 1 http://www.cedroma.usj. edu.lb/pdf/drtsfond/najm.pdf.

52 Pierre Gannagé, Lebanese Law, 341. 
the duty of the state to make possible the exercise of constitutional freedoms. The enactment of a civil personal status law where the religious affiliation of the concerned persons plays no role gives back to religion its true intention. Religion is a matter of heart based on innate human dignity and freedom. One should not be tempted to change one's faith because of certain legal advantages. Many initiatives have thus been submitted in Lebanon to change this state of affairs. They have, however, had to face the resistance of the religious authorities.

In 1998 the then-president of Lebanon, Elias Elhraoui, presented to the Council of Ministers a draft law on facultative civil marriage. ${ }^{53}$ The Lebanese state had already enacted some civil laws in the field of personal status, having removed it from the jurisdiction of religious law as is the case with natural filiation for non-Muslims. This piecemeal approach seems easier for the state to impose than the introduction of a whole facultative civil marriage system. Nevertheless, the Elhraoui proposal to legalize civil marriage provoked an aggressive and hostile reaction from religious leaders. The then-prime minister Hariri refrained from submitting the draft to parliament. ${ }^{54}$ The political actors feared losing the support of the leaders of their respective communities. In fact, the opposition of the religious leaders to civil marriage can be very daunting. For instance, the Sunni Grand Mufti Qabbani issued a fatwa considering any Muslim politician who would support the legalization of civil marriage as an apostate. He added that such a politician would not be entitled to be buried in a Muslim cemetery. ${ }^{55}$ Moreover the enemies of civil marriage advance a constitutional argument. They consider that such a measure would violate Art. 9 of the Constitution since Art. 9 guarantees to the recognized religious communities the respect of their religious personal status regulations. But does the respect of the religious personal status necessarily demand that the state must refrain from legalizing civil marriage and with that establishing a facultative personal status law system? Interestingly the Lebanese Constitutional Council gave the autonomy afforded to the religious community a rather administrative nature, its including, for example, their right to free election of the religious chief without any state interference. ${ }^{56}$ At the same time the Constitutional Council emphasized that the autonomy of the religious communities as enshrined in the Constitution does not prevent the state from exercising its sovereignty-based prerogative of law-making on its territory and for all the people therein. ${ }^{57}$ Without being specific regarding the possibility of the state

53 The draft law is published in, for example, Ibrāhīm Ṭarābulusī, Al-zawāj wa mafă ĩluhu, 278292.

54 Ibrāhīm Ṭarābulusī, Az-zawāj wa mafā īluhu, 275.

55 Mufti Qabbani issues fatwa against civil marriage, Naharnet newsdesk 28.1.2013 http://www.naharnet.com/stories/en/70066.

56 République Libanaise, Conseil Constitutionnel, Decision Nr. 2/2000 du 8.6.2000 http://www.conseilconstitutionnelliban.com/pdf/2-2000-fr.pdf.

57 Conseil constitutionnel, 4. 
to establish a facultative civil marriage system, the Council gave the state a constitutional licence to do so. ${ }^{58}$

The facultative civil system of personal status or of civil marriage is an ongoing field of battle in Lebanese politics and in the society. ${ }^{59}$ The debate thereon has grown even more heated in the last two years when on October 10, 2012 a Sunni citizen contracted a civil marriage with a Shiite citizen before a public notary and chose to subject their marriage to French civil law. ${ }^{60}$ Questions were raised whether their marriage was valid since there was no civil marriage concluded in Lebanon. It should be mentioned that since the issuance of a memorandum of the Ministry of the Interior promulgated December 2009, Lebanese citizens are not required to mention their religious affiliation in civil registry records. ${ }^{61}$ The Sunni-Shiite couple made use of this possibility. In spite of the opposition of the religious leaders, the couple could register their marriage at the civil register on April 25, 2013. It was the first civil marriage concluded in Lebanon to be registered. ${ }^{62}$ This happened thanks to a memorandum of the Higher Committee for Consultations in the Ministry of Justice which argued that nothing in the Lebanese legislation prevents Lebanese from concluding a civil marriage in Lebanon. ${ }^{63}$ For that conclusion they invoked Regulation Nr. 60/LR of 13 March 1936 on the Regulation of the Religious Communities (still in force) which in Art. 10 subjects Lebanese who do not belong to a religious community to the civil legislation in respect of their personal status matters. The Higher Commission followed the reasoning of the couple's lawyers, which argued that the failure of such legislation in Lebanon cannot justify negating the right bestowed on these people to contract a civil marriage in Lebanon.

Many couples followed the example of these two citizens. ${ }^{64}$ This is what probably urged the then-Minister of Justice Qortbawi to submit a draft law allowing Lebanese to conclude civil marriages in Lebanon and to let them be governed by a foreign civil law of their choice. Somewhat surprisingly, the draft entails as a condition

58 Pierre Gannagé, Au fil du temps, 129.

59 Rayane Abou Jaoude, Civil marriage is legal in Lebanon: experts, The Daily Star - Lebanon 10.1.2014, http://www.dailystar.com.lb/News/Lebanon-News/2014/Jan-10/243642-civil-marriage-is-legal-in-lebanon-experts.ashx\#axzz2yHzyQqiF (last visited: 8.4.2014)

60 Béchara Maroun, L'avant-premier "marriage civil" au Liban d'un point de vue legal, L'Orient le Jour 22.1.2013, http:/www.lorientlejour.com/article/797389/L\%27avant-premier_\%3C $\% 3 \mathrm{C}+$ mariage_civil $+\% 3 \mathrm{E} \% 3 \mathrm{E} \_$au_Liban_d $\% 27 \mathrm{un}$ point_de_vue_legal.html (Last visited 8.4.2014).

61 Lebanon moves to tackle religious discrimination, Middle East online 2.12.2009, http://www.middle-east-online.com/english/?id=30381 (last visited 8.4.2014).

62 Jean Aziz, Lebanon's first civil marriage a sign of change Al-Monitor 28.4.2013, http://www.al-monitor.com/pulse/originals/2013/04/lebanon-first-civil-marriage-politicalchange.html (last visited: 8.4.2014).

63 Rayane Abou Jaoude, Civil marriage is legal in Lebanon.

64 Nadim Houry, Paying the clergy is not the way to go, The Daily Star - Lebanon, 7.2.2014 (last visited 8.4.2014) 
for such a registration that a sum of 330 dollars be paid to the religious authority of the husband. ${ }^{6}$

In fact, although marriages such as these are now registered, nothing guarantees their recognition by the Lebanese tribunals. With the last draft law Qortbawi probably sought to give this new practice a more solid legal basis. A draft law providing for a comprehensive optional civil law marriage which was submitted by local civil society groups has been sitting at parliament since March $2011 .^{66}$

\section{Conclusion}

The respect of religious and cultural identities is essential, and the state is obliged to assure it. However, one should not forget an even more important and older identity, the human one. ${ }^{67}$ Fundamental rights are innate. They are based on human dignity shared by all the monotheist religions. Thus the state's main task is to maintain the balance between three components: state, community and citizens. There is a need for autonomy of the state, for autonomy of the community and for citizens having a right of self-determination. ${ }^{68}$

As it is very complicated to put an end to the monopoly that the religious communities have on personal status matters, the state could promote a reform from within the religious communities. Contrary to the general belief, religious laws are not made for eternity. They are able to develop and become adapted to the necessities of the current times. In 2003 the Greek Orthodox synod, for example, adopted a new personal status regulation for its members introducing more equality between men and women in terms of a child's custody and application for divorce. ${ }^{69}$ At present, the question whether such adaptation lies in the near or distant future of Lebanon remains difficult to answer, but it is obvious that the interest and motives for such an evolution exist in the legal and social landscape.

65 Ibid.

66 Ibid.

67 Pierre Gannagé, Au fil du temps, 89-90.

68 Lara Karam-Boustany, Les minorités religieuses au Liban, 782.

69 Law of October 26, 2003 Journal official Nr. 50. 



\title{
Post-Marriage Law and public policy: some remarks on how German courts deal with Islamic rules on divorce
}

\author{
Friederike Wapler
}

The application of Islamic Post-Marriage Law in relation to German legal rules is one of the most complicated issues German family courts have to deal with in the field of private international law. In this paper, I will present three judgments of German civil courts announced in 2012 and 2013, treating different matters of divorce. All of them concern marriages of Iranian people and thus lead to the question of how to deal with Islamic Civil law rules on divorce.

\section{Principles of private international law}

Islamic rules might appear in German court procedures if foreign people from Islamic shaped countries are involved. The court then has to decide on whether to apply foreign law, according to the rules of private international law. This decision follows three main principles:

1. All legal orders are to be respected equally, regardless democratic or autocratic, religious or secular systems.

2. If two legal orders collide, private international law provides a wide range of collision rules. These may lead to one of three possible solutions: (a) The national law of the court's domestic state has to be applied, for example German law in a German proceeding. (b) The involved national law of another state has to be applied, for instance Indonesian law on matters of persons of Indonesian nationality. (c) The persons involved have the choice of which law ought to be applied in their case.

3. The application of foreign legal rules is limited by a general principle called ordre public or public policy: If the foreign regulations lead to a solution that is not compatible with fundamental legal principles of the court's domestic law, they must not be applied. As all legal orders are equal, international private law does not know a common world-wide public policy. Instead, its scope is shaped by the leading principles of every national legal order itself. German public policy mainly consists of the fundamental rights granted in the constitution (basic law), that is particularly human dignity, personal rights and freedoms, and the 
principle of equality. ${ }^{1}$ Thus, public policy might be a powerful means to implement human rights into the discourse of private international law.

\section{German courts on gender-biased aspects of Iranian divorce law}

Now to the first case that was decided by a provincial high court in $2013^{2}$ : An Iranian couple got married in Iran. Some years later, the spouses moved to Germany. After a few years, the wife wished to get divorced. Her husband refused to agree unless his wife abandoned her claim for dowry (mahr). Mahr is a special kind of promise set out in the context of marriage and regulated in Art. 1078 to 1107 of the Iranian Civil Code. In the mahr agreement, the bridegroom promises a certain amount of money, mostly calculated in gold coins, to the bride. After marriage is consummated, the wife may claim for dowry at any time during the marriage or afterwards. In the given case, the wife insisted on getting divorced without refraining from this property claim. In this situation, the civil court had to decide whether or not the wife had such an unrestricted right to divorce. Following the rules of international private law, Iranian family law had to be applied. ${ }^{3}$

Iranian Family law offers gender-specific possibilities for obtaining divorce: A husband may put the marriage to an end by claiming divorce in court without giving any reasons (Art. 1133 of the Iranian Civil Code). ${ }^{4}$ For a wife, divorce is much more difficult to obtain. In case her husband gives his consent, she nevertheless has to refrain from property claims as mahr (Art. 1146 IranCC). In the given case, the husband thus acted according to the rules of this so called $k h u l$ ' divorce. As the wife refused to refrain from the mahr agreement, her claim had to fulfill the conditions of a specific legal divorce ground. In the given case, she claimed to be divorced according to Art. 1130 of the Iranian Civil Code. Wives may obtain divorce under this article if the continuation of the marriage causes difficult and undesirable conditions. To the court's opinion, the wife actually was in a situation of great distress namely

1 See Art. 6 of the German Introductory Act to the Civil Code (EGBGB): "A provision of the law of another country shall not be applied where its application would lead to a result which is manifestly incompatible with the fundamental principles of German law. In particular, inapplicability ensues, if its application would be incompatible with civil rights."

2 Oberlandesgericht Hamm, 17.01.2013, Az. 4 UF 172/12, Zeitschrift für das gesamte Familienrecht 2013,1481 .

3 The application of Iranian Family Law on cases involving people of Iranian nationality is grounded in an agreement between Germany and Iran in 1929, see Niederlassungsabkommen zwischen dem Deutschen Reich und dem Kaiserreich Iran v. 17.02.1929, Art. $8 \S 3$, and to its scope of application E. Unger (2013): Länderbericht Iran, in: Jürgen Rieck, Ausländisches Familienrecht. München: Beck, $\S \S 43$ ff.

4 Iranian Family Law was changed in 2013. Before, husbands were not legally obliged to go to court to get divorced. See for details N. Yassari (2014): Länderbericht Iran, in: Kaiser/Schnitzler (ed.), Nomos Kommentar zum BGB, Bd. 4, Familienrecht, 3. Aufl. Baden-Baden: Nomos, 2812-2828, § 25. 
because the husband, who wanted to separate from his wife himself, denied his consent solely for the reason to avoid his mahr obligation. As to the court's point of view, this situation of being blackmailed by her husband paved the way to a right to divorce under article 1130 of the Iranian Civil Code.

It might be doubted that an Iranian court would have come to the same conclusion: The legal institution of $k h u l$ ' divorce under Art. 1146 IranCC explicitly rules that the wife has to refrain from property claims to achieve her husband's consent. Plus, $k h u l$ ' divorce under the named conditions is quite common in Iranian family law practice. $^{5}$ One might get the idea that the German court constructed its own interpretation of Iranian law without properly considering the legal and cultural context. But this is not the most interesting detail in the judgment's reasoning. On a more general level, the court discussed thoroughly if gender-based unequal access to divorce violates German public policy. The judges stated clearly that a divorce law that treats women extremely unequal does not conform with public policy as it violates the principle of gender equality granted in Art. 3 of German basic law. But with respect to Iranian civil law, the court negated such a violation. Why so, if, as said before, the Iranian Civil Code explicitly allows divorce under different conditions for males and females? The court made two main points: Firstly: "The women's claim for divorce is attached to special conditions, but in the end they can be fulfilled without great effort." ${ }^{\prime 6}$ And secondly, Iranian law allows women to obtain better conditions for divorce claims in a marriage contract. "Thus, under Iranian law, the wife has the possibility to enforce her ideas of the reasons for a possible divorce." ${ }^{97}$ So the German court came to the conclusion that the formal legal inequality in Iranian divorce law practically causes no extreme inequality and therefore does not constitute a violation of public policy.

In this judgment, the court explicitly announces that it does not want to put islamic shaped legal orders under the general suspicion of violating human rights. Surely, this is a praiseworthy approach, and it conforms with the principle of private international law that all legal orders are to be respected as equal. But let me refer to another judgment by the same court just a few months previously: Again, an Iranian wife claimed for divorce and her husband refused to agree. Mahr was no problem here. The problem was as follows: The wife had moved out and accused the husband of having maltreated her. Before court, maltreatment could not be proved. Therefore,

5 See N. Yassari (2013): Understanding and use of Islamic Family Law rules in German courts. The example of the mahr, in: Maurits Berger (ed.), Applying Shar'ia in the West. Facts, fears and the future of Islamic rules on family relations in the West, Leiden: Leiden University Press, 165-187 (169 f.).

6 OLG Hamm, 17.01.2013, Az. II-4 UF 172/12, 4 UF 172/12, § 73: „Das Scheidungsbegehren der Frau wird zwar an besondere Voraussetzungen geknüpft, die aber im Ergebnis ohne allzu erheblichen Aufwand zu erfüllen sein können."

7 OLG Hamm, 17.01.2013, Az. II-4 UF 172/12, 4 UF 172/12, § 74: „Die Ehefrau hat also nach iranischem Gesetz die Möglichkeit, ihre Vorstellungen von den Gründen für eine mögliche Scheidung auch durchzusetzen." 
the court decided that divorce could not be issued as there were no conditions leading the wife to great distress as demanded in Art. 1130 IranCC. $^{8}$ In this case, the woman evidently did not want to live with her husband any more - for whatever reasons - and was denied her right to divorce under Iranian law. How could the same court state some months later that Iranian divorce law was no great obstacle for women to get out of an unwanted marriage? Again, one has to wonder why the court did not discuss public policy in the given legal situation: While her husband could have obtained divorce on whatever reason and was allowed to refuse consent on whatever reasons, his wife had to face relevant legal obstacles. Considering the importance personal relationships have for the identity and freedom of any person, this difference ought to be characterized as an extreme inequality violating womens' fundamental rights to equality and to personal and sexual self-determination. For this reason, the court ought not to have applied Iranian law in this case but to have issued the divorce for reasons of public policy. ${ }^{9}$

\section{The special problem of mahr (dowry)}

The third case deals with the specific legal institution of $m a h r^{10}$ : An Iranian couple got married in Iran, following Iranian family law. The bridegroom promised to the bride a certain amount of golden coins as mahr. Mahr is set up by contract in the marriage ceremony and gains validity if the marriage is consummated. In German juridical practice, the functions of mahr are discussed without coming to a definite conclusion. Actually, mahr is associated with different functions that cannot be separated clearly: It can be seen as a return for the sexual relation with the wife or as a symbol for the wife's worth, or, less symbolic, as a special form of financial security against the risks of repudiation and divorce. In contemporary practice, the latter mentioned economical functions seem to prevail over the symbolic aspect. ${ }^{11}$

In the given case, the couple came over to Germany; their marriage broke. Divorce was ruled out according to German law. Afterwards, the former wife claimed for mahr. Her former husband objected that mahr was not a real entitlement but a symbolic understanding. If he had to pay the worth of the promised gold coins in Euro, he would be ruined. The court now had to decide if and how to accommodate mahr within the scope of German divorce law which does not know such an institution at all.

One of the main questions in this case was therefore if mahr has to be taken seriously at all. There had been different judgments in this matter previously. One local civil court decided that mahr promises tend to include sums that never can be af-

8 OLG Hamm, Zeitschrift für das gesamte Familienrecht 2012, 1498.

9 See S. Henrich, Zeitschrift für das gesamte Familienrecht 2012, 1500.

10 OLG Hamm, 04.07.2012, Az. 8 UF 37/12.

11 See the analysis in Yassari, Understanding and use of Islamic Family Law (note 5), $166 \mathrm{ff}$. 
forded by the husband. ${ }^{12}$ Thus, it characterized mahr as a mere symbolic promise meant to express the worth of the bride. ${ }^{13}$ But this is not the major opinion in German jurisprudence. The Federal Supreme Court (BGH) judged in 2009 that mahr has to be seen as a valid contract between husband and wife. ${ }^{14}$ So did the judges in the case mentioned above. From their point of view, the mahr can even be claimed if the marriage was divorced under German law, because German law generally accepts marriage contracts as valid if they are not immoral ( $\$ 138$ of the German Civil Code). In this respect, mahr agreements have to be taken seriously as contractual obligations binding both parties as any other contract does. ${ }^{15}$ Thus, the court came to the conclusion that the husband had freely agreed with the mahr contract and therefore had to pay the full consequences. ${ }^{16}$ He was issued to pay $213.000 €$ to the wife.

This is a lot of money, comparative to the average cost of living in Germany. Probably for this reason, other German civil courts accepted mahr claims in principle but reduced them with regard to German public policy. ${ }^{17}$ The main reasoning was that the former husband would be ruined financially if ordered to pay the whole sum of mahr. Consequently, he would never be able to get married again. Therefore - as to this approach - an exorbitant mahr claim goes against the fundamental right of the former husband to freely get married (Art. 6 I GG) which also encompasses the right to get married more than once.

From the point of view of a liberal constitutional order, this consideration is not truly convincing. Naturally, freedom of marriage is affected if a person is left with huge financial obligations from a former marriage. But it has to be considered that mahr agreements are freely arranged by executing one's freedom of contract equally guaranteed in the German basic law under Art. $2 \S 1$. It is not the law - neither domestic German nor Iranian law - that tends to overstrain the (former) husband but a freely chosen arrangement - at least as far as following traditional institutions can be freely chosen at all.

Nevertheless the exorbitant sums mahr may encompass cause discomfort, and the mere reference to the principle "agreements have to be kept" seems to be as simplistic as the reduction of mahr to a purely symbolic act. The reason for feeling at unease with high mahr claims in the context of German post-marriage law might be that post-marriage law intends to secure a fair distribution of financial benefits and burdens on two persons who formerly shared lives. German divorce law offers

12 With the reform of Iranian civil law in 2013, mahr was limited to a maximum of 110 gold coins, see Yassari, Länderbericht Iran (note 4), § 17.

13 AG Brühl, 12.10.2010, Az. 32 F 353/10.

14 Federal Supreme Court (BGH), Zeitschrift für das gesamte Familienrecht 2010, 533; see for details Yassari (2011): Die islamische Brautgabe im deutschen Kollisions- und Sachenrecht, in: IPRax (Praxis des Internationalen Privat-und Verfahrensrechts), 63-68.

15 See Yassari, Understanding and use of Islamic Family Law (note 5), 180.

16 See a similar line of reasoning in the recent judgment of AG Buedingen, 06.03.2014, Az. $53 \mathrm{~F}$ 963/13 RI.

17 OLG Bamberg, IPrSpr (Die deutsche Rechtsprechung auf dem Gebiete des Internationalen Privatrechts) 2010, Nr. 89, 190-192 (dowry under Afghan law). 
special legal institutions to obtain such fair arrangements: the equalization of surplus and the legal rules of maintenance. Mahr stands beside those legal instruments and thus holds the danger of unbalancing the respective financial positions of man and woman after marriage by accumulating the advantages of surplus, maintenance, and mahr on the female side. ${ }^{18}$ With this in mind, a third approach favours a contextualization of mahr within the setting of domestic, in this case German law ${ }^{19}$ : While mahr still has to be accepted as valid marriage agreement, it nonetheless has to be taken into account when determining the legal institutions of surplus and maintenance. A high sum of mahr then reduces the amount of surplus as well as the need for maintenance. The inevitable frictions between Islamic and liberal orders of family law might be smoothed by following this line. This seems convincing at least if the marriage was divorced according to German law giving all the advantages of German post marriage law to the wife. The above mentioned case of a divorce procedure following Iranian law has shown that mahr in this context has to be seen as closely connected with the womens' right to divorce at all and therefore be balanced with public policy, expecially with the womens' equality rights.

What conclusion might be drawn from these short and undoubtedly incomplete extracts from German case law? The collision of fundamentally different legal orders raises problems in any field of law. Family, however, is one of the most controversial issues, as family law represents a certain social order, a certain cultural tradition, and, last but not least, a certain gender regime. Those collisions have to be issued with cultural sensitivity, which then again requires sufficient knowledge of the respective foreign rules within their broader legal and cultural context.

18 See Yassari, Länderbericht Iran (note 4).

19 See Yassari, Understanding and use of Islamic Family Law (note 5), $180 \mathrm{f}$. 


\title{
Religiosity in Medical Law of the secular modern age
}

\author{
Gunnar Duttge
}

\section{Legal obligations in a contemporary pluralistic society}

Legal obligations contain instructions and prohibitions of the public constituted legal community, which address all legal subjects and are binding for everyone. Each citizen is entitled to be treated as equal; the "rule of law" and the thereby resulting ban on arbitrary decisions only allow differences where relevant objective differences exist. ${ }^{2}$ However, in a pluralistic society religious and other value-based conceptions are no longer, which is undoubtedly shared by everyone, part of the belief, but a matter of personal-private persuasion. In the interest of piece in society as a whole, the law of an ideologically heterogeneous and more and more multicultural population has to limit itself on securing the outer order and stay neutral towards ideologically-religious beliefs as part of the private sphere, which is guaranteed by human rights. If not, legal requirements cannot be accepted and followed anymore and the claim of law to all-round legal obedience loses its justification. Therefore, the American legal philosopher John Rawls states in his "Theory of Justice": "No conception of the good [meaning the good, successful life], how reasonable and well-founded it might possibly be, entitles its representatives to enforce things, about which there are existing rational disagreements between citizens, with the aid of state coercion." You could also say: The private happiness as well as the salvation lies beyond the political.

This is not supposed to say that the contents of law are utterly untouched by moral or even religious assumptions. On the contrary, until today moral concepts and cultural characteristics have some influence even on the law of a legal community which understands itself as secular. This becomes very clear in those areas of life where existential interests of the human being are on the line, for instance in the various fields of action of human medicine. This is probably where more than elsewhere legal and ethical presuppositions flow together. ${ }^{4}$ Assessments and regulations,

1 To the origins in etymology of the term see: Stern 1984: $764 \mathrm{f}$.

2 See Art. 3 section 1 of the Basic Law for the Federal Republic of Germany (Grundgesetz).

3 In summery the tolerance-principle by Rawls: Hinsch 1994: 35; see in detail Rawls 1975: 35; see also Reese-Schaefer 1997: 636.

4 For example: Duttge 2006: $331 \mathrm{ff}$. 
which are present here, are culturally conditioned to a heightened degree. ${ }^{5}$ The fact that, for example, you can partially find the most different values on so-called "euthanasia" and "assisted dying", on admissibility criteria and approaches in organ donation or on consuming embryo research in international comparison, cannot surprise too much in this light. In democratically constituted legal societies these questions as elsewhere are answered by the majority principle, which is unproblematic as long as all citizens can participate in the constantly flowing process of legal development by expression of opinion and voting rights, and nobody - be it individuals or whole groups - is put into a moral dilemma. The latter is ensured in ethically controversial constellations through so-called "conscience clauses", out of which the right of doctors to refuse an involvement in an abortion (Mitwirkungsverweigerungsrecht $)^{6}$ is certainly the most popular case. ${ }^{7}$

As long as personal conscience or faith conviction only conditions the own thinking or acting and does not collide with the freedom to develop and self-conception of others in social situations or even with the fundamental values of the social community, it is easy for a liberal legal order to grant tolerance. In contrast, it becomes more difficult, where tolerance towards one or a group is intolerance towards others or even the majority of the society at the same time: Whether or to which extent the legal order is still obligated to respect the freedom of religion and conscience or reverse, has to act in the interests of its own system of values according to the motto formulated in Locke's "A Letter Concerning Toleration": "No tolerance towards the intolerance" is the question which stays unanswered until today. Even more: As the arguments about the crucifix in classrooms ${ }^{9}$ and the Muslim headscarf of teachers in school lessons ${ }^{10}$ in Germany have shown, the orientation on the question which positions - from a neutral point of view - can be counted on tolerance or intolerance, becomes indistinct very easily. I would like to trace these basic problems with the aid of three current problems of German medical law, to illustrate how hard it gets to find the right measure by which you can make "just" decisions which can be reasoned convincingly.

\section{Examples of consciences clauses}

\section{Refusal of a life-sustaining therapy}

The first problem actually touches a classic case from the German medical law: A patient refuses a life-sustaining therapy out of ideological reasons which, in medical

\footnotetext{
5 General informations: Schicktanz/Tannert/Weidemann 2004.

6 Section 12 of the German Law on conflict in pregnancy (Schwangerschaftskonfliktgesetz).

7 General informations about the general conflict between personal moral conviction and the rule of law in medical law: Duttge 2014a: $543 \mathrm{ff}$.

8 Locke 1975 (German edition): 93; see in general: Forst 2002: 9 ff.

9 BVerfG v. 16.5.1995, BVerfGE 93, 1 ff.; EGMR v. 3.11.2009, NJW 2011, 3775 ff.

10 BVerfG v. 24.9.2003, BVerfGE 108, $282 \mathrm{ff}$.
} 
opinion, seems more or less "irrational". As long as the patient is able to reason and judicious to a sufficient minimum ${ }^{11}$, he is allowed by law to enforce his subjective rationality, meaning the doctor in charge is forced to respect the so-called "patient autonomy" despite his job-related duties of care. ${ }^{12}$ The doctor doesn't incur a penalty for assisted suicide by omission. ${ }^{13}$ As to the refusal of live-saving banked blood by members of the religious community "Jehovah's Witnesses"14 , their legal position is strengthened even further by the freedom of religion ${ }^{15}$ as the European Court of Human Rights confirmed in its judgment of 10 July 2010. He has decided: "Although the public interest in preserving the life or health of a patient was undoubtedly legitimate and very strong, according to his or her own moral concept it had to yield to the patient's stronger interest in directing the course of his or her own life" (numeral 136).

In order to make sure that the doctors in charge do not have to see themselves degraded as a "submissive plaything" of the patient "without any medical conscience" 16 , in the past, one made use of a trick - with acceptance of the jurisdiction $^{17}$ : They waited until the patient entered the state of being unable to approve and then referred to an "emergency competence" or encouraged the appointment of a custodian, who of course would not belong to that ideological community and therefore interpret the "well-being" of the patient ${ }^{18}$ as life-sustaining, hence to give the consent to a blood transfusion. Since legally establishing the instrument of an absolutely binding living will ${ }^{19}$ in 2009 this path is no longer open, but a new loophole has opened up: Especially because doctors are directly bound to those anticipated declarations of the will of the patient, it is considered that with the existence of a "clear living will" the appointment or involvement of a custodian in decision-making processes is no longer required: Instead, an independent competence to interpret and execute is attributed to the doctors in charge by their professional association -

11 Of course this is a big issue in theoretical and practical way, see Duttge 2013: $77 \mathrm{ff}$.

12 See $\S 1$ of the Medical Association's professional code of conduct.

13 BGHSt 11, 111 ff.; see also Becker-Schwarze 2007: 52; Duttge 2010: Kap. XIV - 13; Hufen 2001: $849 \mathrm{ff}$

$14 \mathrm{http}: / /$ www.jehovaszeugen.de/.

15 Article 4 of the Basic Law for the Federal Republic of Germany (Grundgesetz), Article 9 of the European Convention on Human Rights.

16 Higher Regional Court Munich, MedR 2003, 174 [176]

17 Higher Regional Court Munich, MedR 2003, 174 [176]: „If a member of Jehovah's Witnesses asks of a doctor who does not belong to this religious orientation to possibly take over his treatment and confronts him at this with a living will that refuses blood transfusion, then he cannot assume, even when his declaration is clear, that the doctor would stick by this in every imaginable case by suppressing his medical conscience like a machine and would let him die in the case of an emergency. (...) A doctor, who is in such a way also not reliable in the interests of the Jehovah's Witnesses, (...) cannot be obligated, which should as well infer to a member of Jehovah's Witnesses under the orders of tolerance ..."

18 Section 1901 of the German Civil Code (annex).

19 Section 1901a of the German Civil Code (annex). 
the German Medical Association ${ }^{20}$, , which would result in a consequence that is yet unknown in law: the addressees of a legal obligation would be allowed to define the scope of their boundedness for themselves, without an even rudimentarily effective abuse control. ${ }^{21}$ The lawmaker reacted by establishing the "Patient-right-law" in February 2013 and thus seems to approve this conception ${ }^{22}$, although he should have known two different things: Firstly, the assumption of a sufficient "definiteness", a dispensability of any interpretation of statements, is a result of an interpretation itself; and secondly, the return in strictly legal terms on the right of self-determination through living will, decisions of representatives or the legal concept of the "presumed will" is in no way per se coincident with a material legitimation by the actual, concrete-situative will of the patient.

One might argue that the conflict situation concerning the "Jehovah's Witnesses" is well-known by now ${ }^{23}$ and therefore a defiance of that specific form of a religiously motivated treatment refusal is not expected anymore. But this is rather a result of external pressure through ongoing presence on site and decades of "marketing" than of the "intercultural competence" 24 or "cultural sensibility" of medical staff. Beyond this singular constellation, which is limited on a certain group of people, the respect for wishes of patients out of ideological reasons, which seem irrational, is not ensured, as it can easily be shown with the following constructed example: A follower of the "Falun Gong", a "spiritual meditation movement", founded and systematically persecuted in China, with around 70 to 100 million followers worldwide and in Germany approximately 1,000-2,000 followers, refuses to take her medicine, as it would "weaken her positive body strengths", referring to healing effects of "Qigong", a respiration therapy and meditation technique. ${ }^{25}$ Let us also assume that she is a young, single mother, who has small children to care for and who suffers from a life-threatening weak heart. Does it not seem obvious to ask for her "tolerance" of the fact that an approbated doctor feels obliged to "standard therapy" as well as his "medical conscience" und does not want to risk to be held accountable for medical error or because of the "failure to render assistance"? This together with the medical "sense of responsibility" for the children was at least a sufficient reason for the Munich Higher Regional Court in $2003^{26}$ to even approve the ignoring of a clear living will in the Jehovah's Witnesses constellation.

20 See Empfehlungen der Bundesärztekammer zum Umgang mit Vorsorgevollmacht und Patientenverfügung in der ärztlichen Praxis, Deutsches Ärzteblatt 110 (2013), A-1580 ff.

21 See Duttge 2011: $34 \mathrm{ff}$.

22 Compare Section 630d of the German Civil Code (annex).

23 See BVerfGE 32, 98 ff.; Bender 1999: $260 \mathrm{ff}$. und 2003: $174 \mathrm{ff}$.

24 See Grützmann/Rose/Peters 2012: 323 ff.; Ilkilic 2008: 857 ff.; Tseng/Streltzer 2008.

25 To the background: Heberer 2001, available at: http://web.archive.org/web/ 20070930075942/http://www.uni-duisburg.de/Institute/OAWISS/download/doc/paper36.pdf.

26 Fn. 16. 


\section{Refusal of medicall aid due to conscience or religious reasons}

However, in principle it is undoubted by now that the citation of the medical and nursing conscience cannot justify a compulsory treatment as well. ${ }^{27}$ But how about the refusal of medical aid, be it because of conscience or religious reasons, on the side of the doctor in charge? The case of a dentist who refused the requested treatment because of the young patient - a child who his parents named "Cihad" caused a sensation a few years ago. ${ }^{28}$ The dentist translated it as "holy war" and felt this was a "declaration of war" to everyone who is not of the Islamist faith. It seems reasonable that already the prejudiced translation of the name is objectionable and that in consequence a discriminating behavior of the dentist can be assumed. But under legal maxims the case does not seem to be that simple: When there is no case of emergency, then there is basically no compulsion for the doctor to treat a patient - in here the other side of the free choice of doctor by the patient, who can choose to undertake the elective procedure somewhere else, shows up. ${ }^{29}$ Generally, only people who have a statutory health insurance are entitled to be treated. ${ }^{30}$ But here the doctor is allowed to refuse the treatment, when he, for example, refers to his workload or the lack of a necessary relationship of trust. ${ }^{31}$

Another case of justified refusal to treat is given, when the patient demands medically contraindicated ${ }^{32}$ or even generally prosecutable or unprofessional actions. Especially controversial in Germany at the moment is the assessment of medical aid to suicide ${ }^{33}$ : This, as long as it is about the so-called "freely responsible suicide", which is furthered through help and advice, is not covered by German criminal law ${ }^{34}$, unlike in many other countries. However, the professional code of conduct for German doctors contains a strict prohibition ${ }^{35}$, but this is just a recommendation of the German Medical Association and no obligatory law; the regional Medical Associations, which are legally responsible because of the principle of federation, implemented this recommendation in a variety of different ways: In some regions of Germany the strict prohibition is in force, in others it is just an "ought" rule, and a third group of regions does not have regulations at all. ${ }^{36}$ For the affected doctors this can lead to a moral dilemma in two ways: Firstly, a doctor might feel obliged to assist the suffering patient but is hindered by conduct rules; secondly, it can be reverse: a doctor wants to refuse with a view to his medically

27 BGH NJW 2005, 2385 f;; comments by Höfling (2006: 144); Müller (2005: 924).

28 For example "Die Zeit" vom 5.2.2010.

29 For example: Laufs 2010: $\S 14 \mathrm{Rn} .12 \mathrm{f}$.

30 See $\S 27$ of the social insurance code, book 5 (SGB V).

31 Hecker 2001: $224 \mathrm{ff}$.

32 Leading case: BGH NJW 1978, 1206 (so called: "Zahnextraktionsfall").

33 To the following: Duttge 2014: issue 9 [in printing].

34 See $\S 212, \S 27$ criminal code (annex).

$35 \S 16$ sentence 3 of the Medical Association's professional code of conduct.

36 See Nauck/Ostgathe/Radbruch 2014: A- 67 f.; Rosenau/Sorge 2013: 108, 117; Simon 2010: 708 f. 
ethical self-conception, but the relevant rules of professional conduct do not prohibit the demand of the patient. In the last-mentioned constellation a further reference to willing medical colleagues only seems decidable at first sight; the European Court of Human Rights finds it easily conceivable by now that a positive right to provision of mortal medicine could be inherent in the right to respect for private life. ${ }^{37}$ The individual doctor who upholds the refusal to treat would see himself confronted with the risk of conduct rules' sanctions, as well as every other doctor who assists in medical aid to suicide in the neighboring region, where this is prohibited by conduct rules. It is obvious that this legal situation cannot be described as appropriate.

But how can be dealt with a case in which an acting of the medical staff is linked to a religious symbol, for instance a nurse wearing a necklace with a cross as symbol of her Christian faith during her work at a geriatric ward? Here as well, the European Court of Human Rights was called to give a decision and declared that the aspects of health and patient protection deserve protection and thus have priority: Because of the risk of bodily harming of the patient or of an infection caused by contact with open wounds during treatment or nursing, which is not to be underestimated, it is legitimate, at least in areas of hospitals, to prohibit the wearing of a cross necklace. ${ }^{38}$ This does sound quite reasonable at first, because the practice of the freedom of religion finds its borders in the prohibition of harm; ${ }^{39}$ however, the heart of the present case only asks, if or to which extent the risk of harms can be gone into, when it can be minimized through precautions (like appropriate outer clothing or shortening the necklace). Therefore, the categorical non-tolerance does not go without saying at all, when one also considers that on the side of members of a religion the religious self-conception is at a hazard for a significant time of their life. And when the wearing of choodis (bracelets) or kirpans (ceremonial daggers) by the faithful of the Sikhs is generally forbidden in German hospitals ${ }^{40}$, then this arises the oppressive question whether it is lately also a prejudice concerning foreign and unfamiliar cultures and religions, which resonates within this refusing consensus.

\section{Parental care between refusal of blood transfusion and circumcision}

Finally, let me take up the scenario of the Jehovah's Witnesses from the beginning once more and vary it by an important aspect: Do the members of a religion refuse the blood transfusion not for themselves but for their child, then it is the greatly prevailing opinion that this cannot be tolerated: The parents will not lose the custody as a whole because of violating the "best interests of the child" 41 , but the authority to decide in this concrete case, and the consent will be granted by Family Court. ${ }^{42}$ The

37 Art. 8 ECHR; EGMR, Urteil v. 20.1.2011 - 31322/07 - NJW 2011, 3773 (Case Haas); v. 19.7.2012 - 497/09 - NJW 2013, 2953 (Case Koch); see also Rosenau/Sorge 2013: 108, 111.

38 EGMR, Judgement of 15 January 2013, 48420/10 u.a., NJW 2014, 1935 ff.

39 See f.e. Duttge 2014a: 543 ff. (Fn. 7).

40 See Prunzel 2013: $92 \mathrm{f}$.

41 Section 1666 of the German Civil Code (annex).

42 For example Higher Regional Court Celle, NJW 1995, $792 \mathrm{f}$. 
question here is not the exercise of the right of self-determination in reference to the own personal concerns, but the exercise of the fiduciary duty of care. And the best interests of the children are of importance, as it has been proven by the UN Convention on the Rights of the Child (1989) ${ }^{43}$, and have to be taken into prior account at all state or private decisions (Art. 3 I).

For this purpose the German legislator made a controversially discussed exception at the end of 2012: The new Section 1631d of the German Civil Code now allows the circumcision of male children, whereas the sociopolitical connection to the Jewish and Islamic religious rite only became visible on the edge of the legislative text (see subsection 2). Previously, the Regional Court of Cologne had still judged the circumcision as punishable wrong in a spectacular verdict ${ }^{44}$ and the doctor only was acquitted because of an unindebted error of law. ${ }^{45}$ With both these diametral reverse valuations, the central area of tension, which was mentioned at the beginning, becomes visible: How should each claim of exclusiveness of the colliding validity claims be solved, when on the one side one ascribes more importance to "salvation" than to worldly - and therefore fading - integrity of their body, while on the other side the secular state of the modern age insists on the fact, that civil rights of the others may not be limited by the exercise of religion $?^{46}$

Regardless of any criticism of the details, ${ }^{47}$ the new legislative text creates a religious special right, that cuts across the other current legal valuations: the fiduciary duty of care of the parents to an absolute respect of the best interests of the child, the right of the affected youth to choose the religion ${ }^{48}$ and sustaining principles of current medical law ("Arztvorbehalt" - legal regulations for activities that can only be rendered by a formally qualified doctor, medical indication, treatment lege artis). And it creates a special right to the detriment of a certain group of people, which is in contradiction to the constitutionally guaranteed gender equality: The circumcision of females, which as well dates from centuries-old cultural traditions, is categorically punishable after Section 226 a of the German Criminal Code ${ }^{49}$, which just came into effect as a type of "grievous bodily harm".

43 http://www.national-coalition.de/pdf/UN-Kinderrechtskonvention.pdf.

44 Regional Court of Cologne, NJW 2012, 2128 = NStZ 2012, 449, comments by Kempf 2012: 434; Rox 2012: 805 f.; Spickhoff 2012: $1421 \mathrm{ff}$.

45 Section 17 of the German Criminal Code (annex).

46 See Art. 140 of the Basic Law for the Federal Republic of Germany (Grundgesetz) in conjunction with Art. 136 I Weimar Constitution.

47 See Bernat 2012, 196 ff.; Czerner, 2012: 374 ff., 433 ff.; Herzberg 2009: 332 ff. and 2012: 169 ff. and 2012: 486 ff.; Jerouschek 2012: 171 ff.; Putzke 2008: 1568 ff. and 2008: 669 ff.; Spickhoff 2013: $337 \mathrm{ff}$.

48 See Section 5 KErzG (Law on the religious parenting).

49 See annex. 


\section{Harmonization between the general obligation and the subjectivity of a religious conscience}

The German legal philosopher and instructor of medical law Hans-Ludwig Schreiber got to the heart of the comprehensive difficulty: „How should a balance, a harmonization between the general obligation and the subjectivity of a religious conscience happen?" ${ }^{60}$ The alternative consists in the objectification of the individual conscience, granting it only appreciation as far as it is shaped by an objective advance, which is about consistent with the "real conscience" in the Hegelian meaning. ${ }^{51}$ A liberally constituted community with a guarantee to the fundamental rights of the freedom of religion and conscience assumes another alternative which doesn't locate the reference instance of this exercise of freedom in the „starry sky of natural law“, but in the individual formation of convincement of each person. However, this can only go as far as no rights of third parties or essential interests of the general public are substantially damaged. Where the boundaries run in particular cannot be decreed for all imaginable conflict cases in an abstract-general way, but requires a „rational discourse" (Habermas). Though in general it can be said: "The democratic constitutional state has to ensure that (...) the trust of the citizens in the law does not get destroyed by unwise indulgence and laissez-faire (...) However, on the other side the respect for the fundamental right of the freedom of religion and conscience provides legitimacy and thereby inner stability to the democratic constitutional state ${ }^{652}$.

\section{Annex:}

\section{Section 630d of the German Civil Code (Consent)}

(1) Prior to implementing medical treatment, in particular a procedure affecting the body or health, the treating party is obliged to acquire the consent of the patient. If the patient is unable to consent, the consent of a party entitled to do so is to be acquired unless a living will in accordance with section 1901a (1) sentence 1 permits or prohibits the measure (...)

$(2)-(3)[\ldots]$

\section{Section 1631d of the German Civil Code (Circumcision of the malle child)}

(1) The care for the person of the child includes the right to give consent to the medically unnecessary circumcision of a male child who is not capable of reasoning and forming a judgment, if this is to be carried out in accordance with the rules of medical practice. This does not apply if the circumcision, even considering its purpose, jeopardizes the best interests of the child.

50 Schreiber 1993: 29.

51 See Hegel 2013: §137.

52 Isensee 1993: 41, 59. 
(2) In the first six months after the child is born, circumcision may also be performed pursuant to subsection (1) by persons designated by a religious group to perform this procedure if these persons are specially trained to do so and, without being a physician, are comparably qualified to perform circumcisions.

\section{Section 1666 of the German Civil Code (Court measures in the case of endangerment of the best interests of the child)}

(1) Where the physical, mental or psychological best interests of the child or its property are endangered and the parents do not wish or are not able to avert the danger, the family court must take the measures necessary to avert the danger.

(2) In general it is to be presumed that the property of the child is endangered if the person with care for the property of the child violates his maintenance obligation towards the child or his duties connected with the care for the property of the child or fails to comply with orders of the court that relate to the care for the property of the child.

(3) The court measures in accordance with subsection (1) include in particular

1. instructions to seek public assistance, such as benefits of child and youth welfare and healthcare,

2. instructions to ensure that the obligation to attend school is complied with,

3. prohibitions to use the family home or another dwelling temporarily or for an indefinite period, to be within a certain radius of the home or to visit certain other places where the child regularly spends time,

4. prohibitions to establish contact with the child or to bring about a meeting with the child,

5. substitution of declarations of the person with parental custody,

6. part or complete removal of parental custody.

(4) In matters of care for the person of the child, the court may also undertake measures with effect against a third party.

\section{Section 1901 of the German Civil Code (Scope of the custodianship, duties of the custodian)}

(1) The custodianship includes all activities that are necessary to attend to the affairs of the person under custodianship from a legal point of view in accordance with the following provisions.

(2) The custodian must attend to the affairs of the person under custodianship in a manner that is conducive to his welfare. The best interests of the person under custodianship also includes the possibility for him, within his capabilities, to shape his life according to his own wishes and ideas.

(3) The custodian must comply with wishes of the person under custodianship to the extent that this is not inconsistent with the best interests of the latter and can be expected of the custodian. This also applies to wishes which the person under custodianship expressed before the appointment of the custodian, unless he discernibly does not wish to uphold these wishes. Before the custodian deals with important 
matters, he discusses them with the person under custodianship, to the extent that this is not inconsistent with the best interests of the latter.

(4) $-(5)$

\section{Section 1901a of the German Civill Code (Living will)}

(1) If a person of full age who is able to consent has determined in writing, for the event of his becoming unable to consent, whether he consents to or prohibits specific tests of his state of health, treatment or medical interventions not yet directly immanent at the time of determination (living will), the custodian must examine whether these determinations correspond to the current living and treatment situation. If this is the case, the custodian must see to it that the will of the person under custodianship is done. A living will may be revoked at any time without a specific form.

(2) If there is no living will, or if the determinations of a living will do not correspond to the current life and treatment situation, the custodian must determine the wishes with regard to treatment or the presumed will of the person under custodianship, and decide on this basis whether he consents to or prohibits a medical treatment pursuant to subsection (1). The presumed will must be ascertained on the basis of concrete indications. Consideration must be given, in particular, to previous oral or written statements, ethical or religious convictions and other personal values of the person under custodianship.

(3) Subsections (1) and (2) apply regardless of the nature and stage of any illness of the person under custodianship.

(4) No one may be obliged to establish a living will. The conclusion of a contract may not be made contingent on the establishment or submission of a living will.

(5) Subsections (1) to (3) apply to authorised representatives with the necessary modifications.

\section{Section 17 of the German Criminal Code (Mistake of law)}

If at the time of the commission of the offence the offender lacks the awareness that he is acting unlawfully, he shall be deemed to have acted without guilt if the mistake was unavoidable. If the mistake was avoidable, the sentence may be mitigated pursuant to section $49(1)$.

\section{Section 27 of the German Criminal Code (Aiding)}

(1) Any person who intentionally assists another in the intentional commission of an unlawful act shall be convicted and sentenced as an aider.

(2) The sentence for the aider shall be based on the penalty for a principal. It shall be mitigated pursuant to section 49 (1).

\section{Section 212 of the German Criminal Code (Murder)}

(1) Whosoever kills a person without being a murderer under section 211 shall be convicted of murder and be liable to imprisonment of not less than five years.

(2) ... 


\section{Section 226a of the Criminal Code (Concision of female genitalia)}

(1) Whosoever dismembers the outer genitals of a female person shall be liable to imprisonment of not less than one year.

(2) In less serious cases the penalty shall be imprisonment from six months to five years.

\section{References:}

Becker-Schwarze, Kathrin (2007): Patientenautonomie aus juristischer Sicht, in: Familie, Partnerschaft, Recht 2007/3, 52.

Bender, Albrecht W. (1999): Umgang mit Vorsorgevollmacht und Patientenverfügung in der ärztlichen Praxis. Zeugen Jehovas und Bluttransfusion, in: Medinzinrecht, 260.

- (2003): Eingeschränkte Verbindlichkeit des Vetos eines Zeugen Jehovas gegen eine Bluttransfusion selbst bei ausdrücklicher und aktueller Willensäußerung in einer Patientenverfügung, in: Medizinrecht, 174.

Bernat, Erwin (2012): Die rituelle Beschneidung nichteinwilligungsfähiger Knaben, Zugleich Besprechung von LG Köln, Urt. v. 7. 5. 2012 - 151 Ns 169/11, in: Zeitschrift für Familien- und Erbrecht (EF-Z 2012), 196.

Bormann, Franz-Josef / Wetzstein, Verena (2014): Gewissen. Dimensionen eines Grundbegriffs medizinischer Ethik. Berlin: De Gruyter.

Brugger, Winfried / Haverkate, Görg (2002): Grenzen als Thema der Rechts und Sozialphilosophie. Archiv für Rechts- und Sozialphilosophie - Beiheft (ARSP-B) Nr. 84, Stuttgart: F. Steiner.

Czerner, Frank (2012): Staatlich legalisierte Kindeswohlgefährdung durch Zulassung ritueller Beschneidung zugunsten elterlicher Glaubensfreiheit?, in: Zeitschrift für Kindschaftsrecht und Jugendhilfe (ZKJ) 2012, $374 \mathrm{ff}$. (Teil 1) und $433 \mathrm{ff}$. (Teil 2).

Degener, Wilhelm / Heghmanns, Michael (2012): Festschrift für Friedrich Dencker zum 70. Geburtstag. Tübingen: Mohr Siebeck.

Duttge, Gunnar (2006): Zukunftsperspektiven der Medizinethik - aus Sicht des Rechts. In: Ethik in der Medizin, 331.

- (2011): Patientenverfügung unter ärztlicher Deutungshoheit?, in: Intensivmedizin und Notfallmedizin 48, 34.

- (2014a): Das Gewissen im Kontext des modernen Arztrechts, in: Bormann/Wetzstein (ed.), Gewissen. Dimensionen eines Grundbegriffs medizinischer Ethik, 543.

- (2014b): Der assistierte Suizid: Ein Dilemma nicht nur der Ärzteschaft - Ein kritischer Kommentar zu den ,Reflexionen “ der DGP, in: Medizinrecht, Issue 9 [in printing]

Eckart, Joachim / Forst, Helmut / Briegel, Josef (2010): Repetitorium um Intensivmedizin. (Loseblatt Handbuch) 39. Ergänzungslieferung, Berlin.

Grützmann, Tatjana / Rose, Christina / Peters, Tim (2012): Interkulturelle Kompetenz in der medizinischen Praxis, in: Ethik in der Medizin 2012/24, 323.

Heberer, Thomas (2001): Falungong - Religion, Sekte oder Kult? Duisburger Arbeitspapiere Ostasienwissenschaften Nr. 36/2001.

Hecker, Dorothee (2001): Die Vertragsabschlussfreiheit des Arztes bei gestörtem Vertrauensverhältnis zum Patienten. In: Medizinrecht 2001, 224. 
Hegel, Georg Wilhelm Friedrich (2013): Grundlinien der Philosophie des Rechts. Hamburg: Meiner 2013.

Herzberg, Rolf-Dietrich (2009): Rechtliche Probleme der rituellen Beschneidung, in: Juristenzeitung (JZ) 2009, 332 .

- (2012): Steht dem biblischen Gebot der Beschneidung ein rechtliches Verbot entgegen?, in: Medizinrecht 2012, 169

- (2012): Die Beschneidung gesetzlich gestatten?, in: Zeitschrift für Internationale Strafrechtsdogmatik (ZIS) 2012, 486.

Hinsch, Werner (1994): Einleitung, in: John Rawls, Die Idee des politischen Liberalismus. Frankfurt/M 1994, 1.

Höfling, Wolfram (2006): Entscheidungen - BGH, 8.6.2005 - XII ZR 177-03 - Zum Abbruch der künstlichen Ernährung eines betreuten Patienten, in: Juristenzeitung (JZ) 2006, 144.

Höver, Gerhard / Honnefelder, Ludger (1993): Der Streit um das Gewissen. Paderborn: Ferdinand Schöningh.

Hufen, Friedhelm (2001): In dubio pro dignitate - Selbstbestimmung und Grundrechtsschutz am Ende des Lebens, in: Neue Juristische Wochenzeitschrift (NJW) 2001, 849.

Ilkilic, Ilhan (2008): Kulturelle Aspekte bei ethischen Entscheidungen am Lebensende und interkulturelle Kompetenz, in: Bundesgesundheitsblatt - Gesundheitsforschung - Gesundheitsschutz 51 (2008), 857.

Isensee, Josef (1993): Gewissen im Recht - Gilt das allgemeine Gesetz nur nach Maßgab des individuellen Gewissens? (Korreferat), in: Höver, Gerhard / Honnefelder, Ludger (1993): Der Streit um das Gewissen. Paderborn: Ferdinand Schöningh, 41.

Jerouschek, Günter (2012): Beschneidung - Heileingriff, religiöses Gebot oder strafbare Körperverletzung?, in: Festschrift für Friedrich Dencker zum 70. Geburtstag (eds. Wilhelm Degener/Michael Heghmanns): Tübingen: Mohr Siebeck, 171.

Kempf, Claudia (2012): Anmerkung zur Entscheidung des LG Köln vom 07.05.2012 (151 Ns 169/11; JR 2012, 434) - Zur Frage, ob die Beschneidung von Kleinkindern eine strafbare Körperverletzung darstellt, in: Juristenzeitung (JZ) 2012, 434.

Kindhäuser , Urs / Neumann, Ulfrid / Paeffgen, Hans-Ullrich (2013): Strafgesetzbuch - Band 2. 4. Auflage. Baden-Baden: Nomos 2013.

Laufs, Adolf / Kern, Bernd-Rüdiger (2010): Handbuch des Arztrechts. 4. Auflage. München: Beck.

Locke, John (1975): Ein Brief über Toleranz. Hamburg: Meiner.

Montgomery, Frank Ulrich / Wiesing, Urban (2013): Umgang mit Vorsorgevollmacht und Patientenverfügung in der ärztlichen Praxis, in: Deutsches Ärzteblatt 110A-1580.

Müller, Gabriele (2005): Einstellen der künstlichen Ernährung auf Verlangen des Betreuers entgegen dem Willen des Pflegeheims, in: Deutsche Notar-Zeitschrift (DnotZ) 2005, 924

Nauck, Friedemann / Ostgathe, Christoph / Radbruch, Lukas (2014),: Ärztlich assistierter Suizid: Hilfe beim Sterben - keine Hilfe zum Sterben. In: Deutsches Ärzteblatt 111 A-67.

Prunzel, Regine (2013): Das Kreuz mit dem Kreuz: Wo das Tragen religiöser Symbole seine Grenzen erfährt, in: Rechtsdepesche für das Gesundheitswesen (RDG) 2013/2, 92.

Putzke, Holm (2008): Juristische Positionen zur religiösen Beschneidung, Besprechung von OLG Frankfurt a.M., Beschl. v. 21.8.2007 (4 W 12/07), in: Neue Juristische Wochenzeitschrift (NJW) 2008, 1568.

Putzke, Holm / Hardtung, Bernhard / Hoernle, Tatjana (2008): Strafrecht zwischen System und Telos. Festschrift für Rolf Dietrich Herzberg zum siebzigsten Geburtstag. Tübingen: Mohr Siebeck. 
Rawls, John (1975): Eine Theorie der Gerechtigkeit. Frankfurt am Main: Suhrkamp.

- (1994): Die Idee des politischen Liberalismus. Frankfurt am Main: Suhrkamp.

Reese-Schaefer, Walter (1997): Grenzgötter der Moral. Der neuere europäisch-amerikanische Diskurs zur politischen Ethik. Frankfurt a.M.: Suhrkamp.

Rosenau, Henning / Sorge, Igor (2013): Gewerbsmäßige Suizidförderung als strafwürdiges Unrecht?, in: Neue Kriminalpolitik (NK) 2013, 108.

Rox, Barbara (2012): Anmerkung zum Urteil des LG Köln vom 07.05.2012 (151 Ns 169/11) - Zur Bewertung des Elternrechts bei der Beschneidung eines minderjährigen Kindes, in: Juristenzeitung (JZ) 2012, 805.

Schicktanz, Silke / Tannert, Christoph / Wiedemann, Peter (2004): Kulturelle Aspekte der Biomedizin. Frankfurt a. M.: Campus.

Schreiber, Hans-Ludwig (1993): Gewissen im Recht. Gilt das allgemeine Gesetz nur nach Maßgab des individuellen Gewissens?, in: Höver, Gerhard / Honnefelder, Ludger (1993): Der Streit um das Gewissen. Paderborn: Ferdinand Schöningh, 29.

Simon, Alfred (2010): Die Debatte um die ärztliche Beihilfe zum Suizid, in: Hessisches Ärzteblatt 71/11, 708 .

Simon, Alfred / Wiesemann, Claudia (2013): Patientenautonomie: Theoretische Grundlagen - Praktische Anwendungen. Münster: Mentis.

Spickhoff, Andreas (2012): Anmerkung zum Urteil des LG Köln vom 07.05.2012, in: Zeitschrift für das gesamte Familienrecht (FamRZ) 2012, 1421.

Stern, Klaus (1984): Das Staatsrecht der Bundesrepublik Deutschland Bd. I. 2. Auflage, München: Beck.

Tseng, Wen-Shing / Streltzer, Jon (2008): Cultural competence in health care. Berlin: Springer 


\section{List of contributors (alphabetic order)}

Muhrisun Afandi

Universitas Islam Negeri Sunan Kalijaga, Yogyakarta

Claudia Derichs

Philipps-Universität Marburg, Marburg

Gunnar Duttge

Georg-August-Universität Göttingen, Göttingen

Siti Ruhaini Dzuhayatin

Universitas Islam Negeri Sunan Kalijaga, Yogyakarta

Imen Gallala-Arndt

Max Planck Institute for Comparative and International Private Law, Hamburg

Noorhaidi Hasan

Universitas Islam Negeri Sunan Kalijaga, Yogyakarta

Syafiq Hasyim

Universitas Islam Negeri Syarif Hidayatullah, Jakarta

Hamim Ilyas

Universitas Islam Negeri Sunan Kalijaga, Yogyakarta

Saifuddin

Universitas Islam Negeri Sunan Kalijaga, Yogyakarta

Irene Schneider

Georg-August-Universität Göttingen, Göttingen

Fritz Schulze

Georg-August-Universität Göttingen, Göttingen

Friederike Wapler

Johann Wolfgang Goethe-Universität Frankfurt, Frankfurt am Main 
